\title{
Caracterização ambiental e hidrológica da bacia hidrográfica do Rio Jacarecica
}

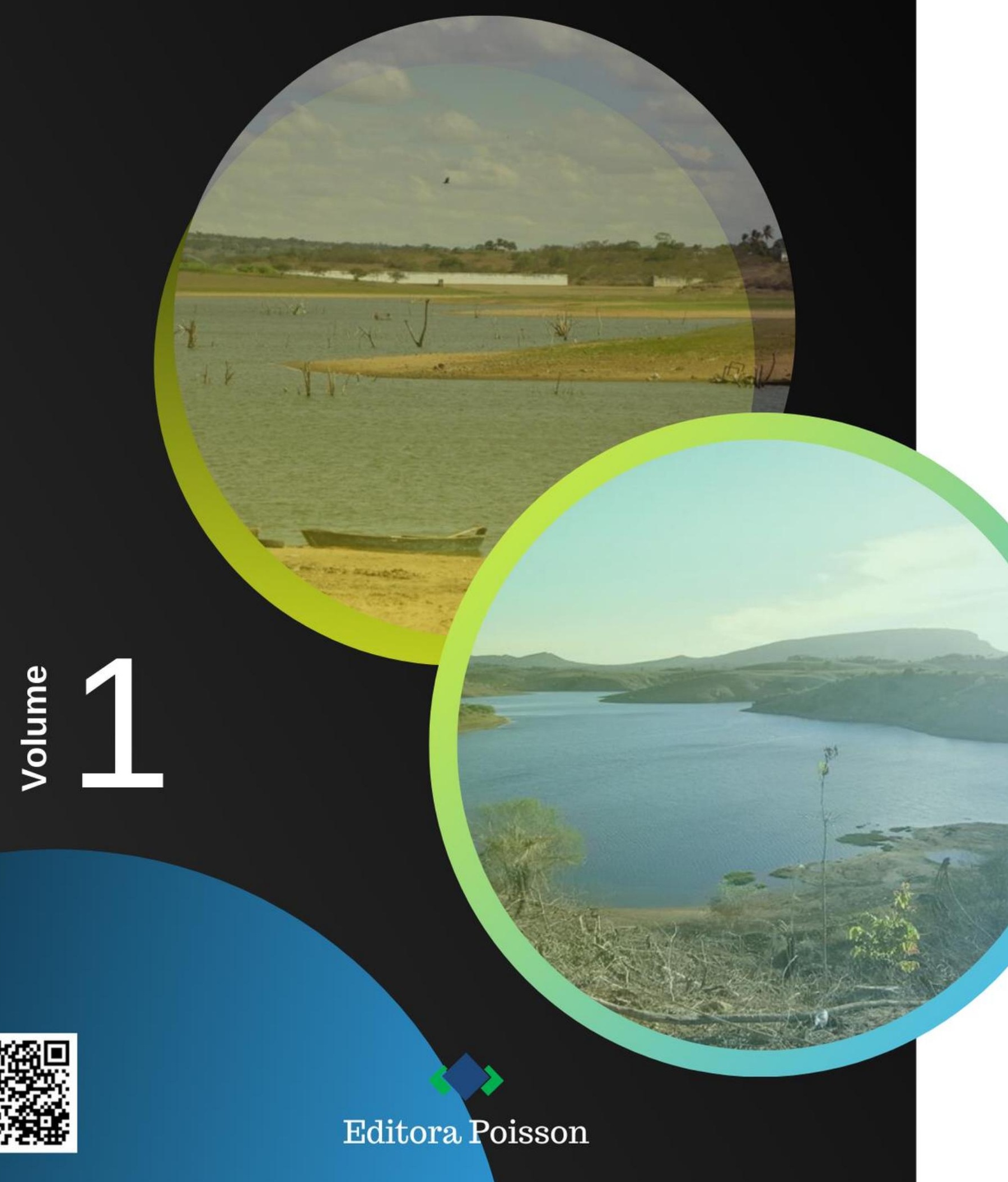


Organizadores:

Carlos Alexandre Borges Garcia

Inajá Francisco de Sousa

Adnivia Santos Costa Monteiro

Neuma Rúbia Figueiredo Santana

CARACTERIZAÇÃO AMBIENTAL E HIDROLÓGICA DA BACIA HIDROGRÁFICA DO RIO JACARECICA

VOLUME 1

1ํㅡㄹição

Belo Horizonte

Poisson

2020 


\section{Editor Chefe: Dr. Darly Fernando Andrade}

\section{Conselho Editorial}

Dr. Antônio Artur de Souza - Universidade Federal de Minas Gerais

Ms. Davilson Eduardo Andrade

Dra. Elizângela de Jesus Oliveira - Universidade Federal do Amazonas

Msc. Fabiane dos Santos

Dr. José Eduardo Ferreira Lopes - Universidade Federal de Uberlândia

Dr. Otaviano Francisco Neves - Pontifícia Universidade Católica de Minas Gerais

Dr. Luiz Cláudio de Lima - Universidade FUMEC

Dr. Nelson Ferreira Filho - Faculdades Kennedy

Ms. Valdiney Alves de Oliveira - Universidade Federal de Uberlândia

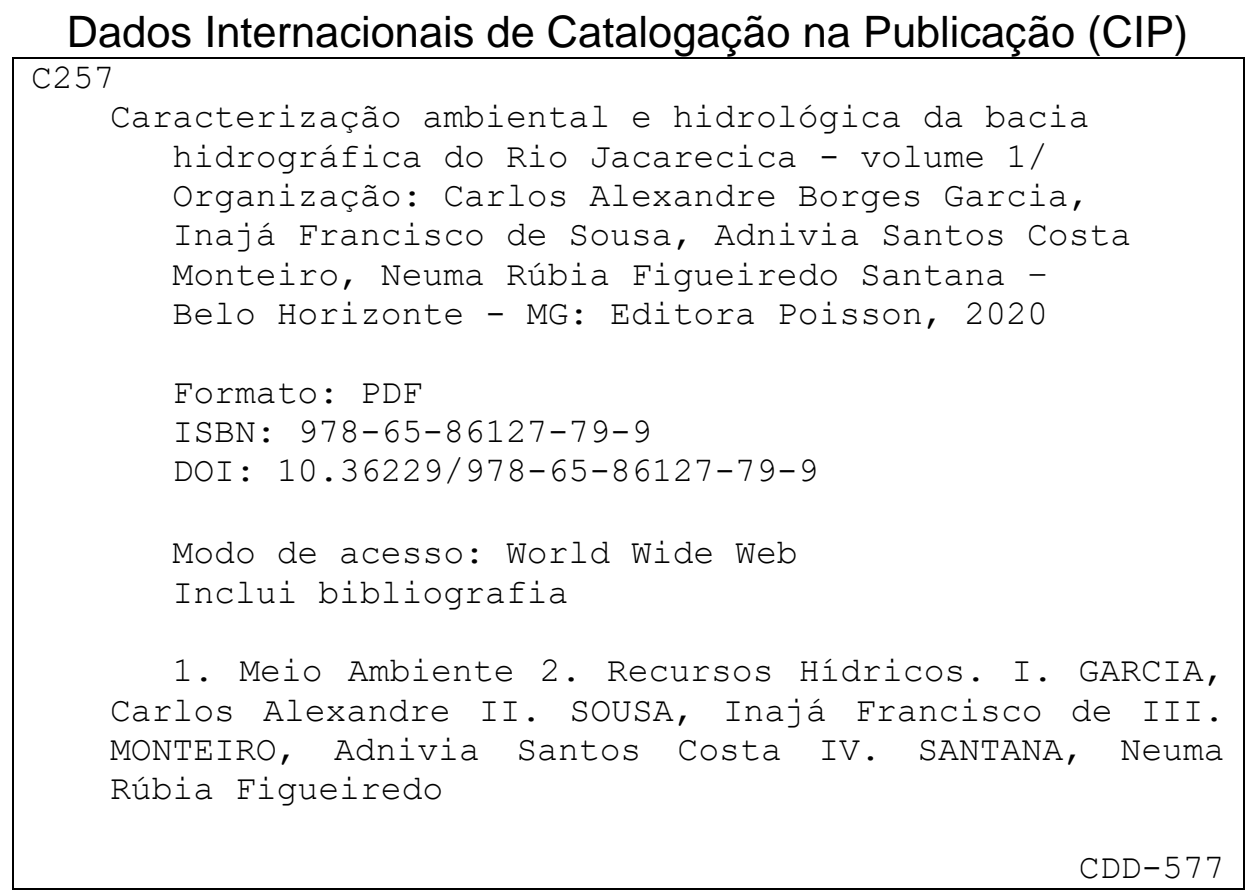

O conteúdo dos artigos e seus dados em sua forma, correção e confiabilidade são de responsabilidade exclusiva dos seus respectivos autores

$\underline{\text { www.poisson.com.br }}$

contato@poisson.com.br 


\section{PREFÁCIO}

A preocupação com a formação de quadros profissionalizados na área de recursos hídricos e na gestão do Sistema é, em si mesma, uma inovação, decorrente em primeira instância da nova legislação federal e estadual de recursos hídricos; em segunda instância, decorrente da maior consciência dos governos federal e estadual quanto ao seu papel para a preservação das águas e da necessidade de gerenciamento responsável dos recursos hídricos e do meio ambiente.

Atualmente, há um consenso muito bem fundamentado no meio científico de que a bacia hidrográfica é a unidade ambiental mais adequada para o tratamento dos componentes e da dinâmica das inter-relações concernentes ao planejamento e à gestão do desenvolvimento, especialmente no âmbito regional. A adoção das bacias hidrográficas como unidade de estudo traz consigo, implicitamente, o compromisso da abordagem interdisciplinar e do trabalho em equipe, duas premissas básicas, essenciais para atingir o almejado desenvolvimento sustentável. É exatamente nesse aspecto que a obra ora levada a público representa uma contribuição oportuna e de grande relevância.

Em 2007 e 2008, a UFS em parceria com a SEMARH, atual SEDURBS e a Universidade de São Paulo - USP ofertou um Curso de Aperfeiçoamento em Gestão de Recursos Hídricos voltado para profissionais das mais diversas áreas de atuação e para integrantes dos Comitês de Bacias Hidrográficas, capacitando trinta e três técnicos.

Posteriormente em parceria com a SEDURBS, a Universidade Federal de Sergipe - UFS realizou o Curso de Especialização em Gestão de Recursos Hídricos e Meio Ambiente, com carga horária de 420 horas, formando vinte e quatro especialistas que trabalham em áreas relacionadas aos recursos hídricos.

Em todos os capítulos, e no conjunto da obra, é evidenciada a constante preocupação dos autores com o tratamento integrado, interdisciplinar, das complexas relações envolvidas no processo dinâmico do desenvolvimento regional, utilizando a bacia hidrográfica como unidade ambiental de pesquisa e planejamento.

Este livro fruto das monografias apresentadas, presta uma valiosa colaboração para o Sistema Estadual de Gerenciamento de Recursos Hídricos, em especial a caracterização ambiental e hidrológica do rio Jacarecica, importante afluente da bacia hidrográfica do rio Sergipe.

Aracaju/SE, 19 de março de 2020.

Ailton Francisco da Rocha

Superintendente Especial de Recursos Hídricos

e Meio Ambiente 


\section{Fontes de Recursos:}

Contrato 085/2013 (ANA) - Programa de Consolidação do Pacto Nacional pela Gestão das Águas (PROGESTÃO)

Fundo Estadual de Recursos Hídricos (FUNERH)

\section{Jackson Barreto de Lima}

Governador

\section{Belivaldo Chagas Silva}

Vice-Governador

\section{Olivier Ferreira das Chagas}

Secretário de Estado do Meio Ambiente e dos Recursos Hídricos

\section{Ailton Francisco da Rocha}

Superintendente de Recursos Hídricos

A comissão organizadora vem agradecer a CAPES - Coordenação de Aperfeiçoamento de Pessoal de Nível Superior, pelo apoio financeiro da Publicação dos volumes 1 e 2 do livro CARACTERIZAÇÃO AMBIENTAL E HIDROLÓGICA DA BACIA HIDROGRÁFICA DO RIO JACARECICA.

Recursos oriundo do Processo: 88881.157414/2017-01

Número do Auxílio: 1968/2017 


\title{
Agradecimentos
}

\section{Angelo Roberto Antoniolli}

Reitor Universidade Federal do Sergipe

\section{Coordenação}

Prof. Dr. Inajá Francisco de Sousa

Coordenação Geral

Prof. Dr. Antenor de Oliveira Aguiar Netto

Vice- coordenação

\section{Angela Maria do Nascimento Lima}

Coordenação do Contrato 01/2011

\section{Corpo Docente}

Profa. Dr.a Ana Alexandrina Gama da Silva

Prof. Dr. Antenor de Oliveira Aguiar Netto

Prof. Dr. Ariovaldo Antonio Tadeu Lucas

Prof. Dr. Carlos Alexandre Borges Garcia

Prof. Msc.Eduardo Lima de Matos

Profa. Dr.a Elisangela de Andrade Passo

Profa. Dr.a Eva Maria de Siqueira Gama da Silva

Prof. Dr. Gregório Guirardo Faccioli

Prof. Dr. Inajá Francisco de Sousa

Prof. Dr. José Antonio Almeida Pacheco

Prof. Dr. José do Patrocínio Hora Alves

Profa. Dr.a Josefa Eliane Santana de Siqueira Pinto

Profa. Dr.a Laura Jane Gomes

Prof. Dr. Marcus Aurélio Soares Cruz

Prof. Dr. Ricardo Aragão

Prof. Dr. Robério Anastácio Ferreira

\author{
Alunos \\ Ana Carolina Oliveira Freitas \\ Angela Maria do Nascimento Lima \\ Antonio Carlos S.Góis \\ Claudomir Tavares da Silva \\ Elizabeth Azevedo de Oliveira \\ Elaine Christian Barbosa dos Santos \\ Gladyson Alves de Oliveira \\ Igor Pinheiro Rocha \\ Ismeralda Maria C.B.N.Barreto \\ Karine Resende Araújo \\ Lanielle Amarante Santana \\ Lucas de Oliveira Cunha \\ Luciano Costa Macedo \\ Luis Carlos Souza Silva \\ Maria de Fátima Campos de Sá \\ Mario Leo de Oliveira Rodrigues \\ Nicea Souza da Piedade \\ Patrícia Prado Cabral Souza \\ Ruberval Leoni Azevedo \\ Sergio Luis Rocha \\ Tânia Ribeiro dos Santos \\ Valbério Paolilo dos Santos
}




\section{SUMÁRIO}

Capítulo 1: Análise morfométrica da bacia hidrográfica do rio Jacarecica, no estado de Sergipe, utilizando 0 aplicativo Archydro.

Sérgio Luís Rocha, José Antonio Pacheco de Almeida

DOI: $10.36229 / 978-65-86127-79-9 . C A P .01$

Capítulo 2: Classificação climática da bacia hidrografica do rio Jacarecica.

Ruberval Leone Azevedo, Inajá Francisco de Sousa

DOI: 10.36229/978-65-86127-79-9.CAP.02

Capítulo 3: Utilização do atlas de recursos hídricos do estado de Sergipe para mapeamento das áreas de preservação permanente em margens de corpos d'água da bacia do rio Jacarecica....... Igor Pinheiro da Rocha, José Antonio Pacheco de Almeida

DOI: 10.36229/978-65-86127-79-9.CAP.03

Capítulo 4: Avaliação da qualidade da água do açude da Marcela na sub-bacia hidrográfica do rio Jacarecica - SE

Karine Resende Araújo, Elisangela de Andrade Passos, Carlos Alexandre Borges Garcia

DOI: 10.36229/978-65-86127-79-9.CAP.04

Capítulo 5: Avaliação do sistema agreste de abastecimento de água potável

Mário Leo de Oliveira Rodrigues, Gregorio Guirado Faccioli

DOI: 10.36229/978-65-86127-79-9.CAP.05

Capítulo 6: Avaliação do desempenho de sistemas de irrigação em lotes do perímetro irrigado Jacarecica I

Valbério Paolilo dos Santos, Ariovaldo Antonio Tadeu Lucas

DOI: 10.36229/978-65-86127-79-9.CAP.06

Capítulo 7: Impactos ambientais na sub-bacia hidrográfica do rio Jacarecica

Lanielle Amarante Santana, Josefa Eliane Santana de Siqueira Pinto

DOI: 10.36229/978-65-86127-79-9.CAP.07

Capítulo 8: Riscos ambientais no uso de agrotóxicos nos perímetros irrigados Jacarecica I e II ... Ismeralda Maria Castelo Branco do Nascimento Barreto, Josefa Eliane Santana de Siqueira Pinto DOI: 10.36229/978-65-86127-79-9.CAP.08

Capítulo 9: Estimativa de produtividade da cultura do sorgo a partir do metodo da zona agroecologica (ZAE) no perimetro irrigado Jacarecica I

Capítulo 10: Comitê da bacia hidrográfica do rio Sergipe (CBHS): Aspectos Legais e Estruturantes na Gestão das Águas 


\title{
CAPÍTULO 01 \\ Análise morfométrica da bacia hidrográfica do rio Jacarecica, no estado de Sergipe, utilizando o aplicativo Archydro
}

\author{
Sérgio Luís Rocha \\ José Antonio Pacheco de Almeida
}

\section{INTRODUÇÃO}

Desde o início de nossa história, o homem vem desenvolvendo e aprimorando técnicas e ferramentas, nas mais diversas áreas do conhecimento humano, para melhor compreender a realidade em que vive. Nas últimas décadas, com o avanço das tecnologias e o advento da informatização, aperfeiçoaram-se os procedimentos metodológicos orientadores da investigação e compreensão científica dos componentes naturais.

Neste contexto, destaca-se o geoprocessamento que, segundo Câmara e Davis (2001), é a área do conhecimento que utiliza técnicas matemáticas e computacionais para o tratamento da informação geográfica e que vem influenciando de maneira crescente as áreas de cartografia, análise de recursos naturais, transportes, comunicação, energia e planejamento urbano e regional. Neste sentido, o geoprocessamento é uma tecnologia formada pela confluência de outras tecnologias, a exemplo do sensoriamento remoto e dos sistemas de informações geográficas (SIG).

Vale ressaltar que o sensoriamento remoto é um conjunto de técnicas que possibilita a obtenção de informações sobre alvos na superfície terrestre (objetos, áreas, fenômenos), através do registro da interação da radiação eletromagnética com a superfície, realizado por instrumentos denominados de sensores, sem que haja contato direto com o alvo investigado. Enquanto que, um sistema de informação geográfica (SIG ou GIS - Geographic Information System) é um conjunto poderoso de ferramentas constituído por uma série de programas e processos de análise, cuja característica principal é focalizar o relacionamento de determinado fenômeno da realidade com sua localização espacial.

Neste estudo, utilizamos as ferramentas do ArcHydro incorporadas ao ArcGis 10.0 para realizar a Análise Morfométrica da Bacia Hidrográfica do Rio Jacarecica, Sergipe. As ferramentas ArcHydro são usadas para derivar vários conjuntos de dados que coletivamente descrevem os padrões de drenagem de uma bacia hidrográfica. A análise de varredura é realizada para gerar dados sobre direção, acumulação, definição e segmentação de fluxo, e delimitação de bacias hidrográficas. Estes dados são então utilizados para desenvolver uma representação vetorial das bacias de drenagem e linhas a partir de um ponto selecionado. Usando esta informação, uma rede geométrica é construída.

Para o processo de delineamento e a caracterização morfométrica da bacia hidrográfica do rio Jacarecica e da rede de drenagem associada utilizamos a função DEM Reconditioning. A função DEM Reconditioning modifica Modelos Digitais de Elevação (MDE), impondo características lineares para eles (burning/fencing). A rede de drenagem é "marcada' sobre o MDE como se fosse um ferro de marcar no couro de um boi. Esta função é uma implementação do método AGREE desenvolvido por Ferdi Hellweger na Universidade do Texas em Austin, em 1997.

O método AGREE - DEM Surface Reconditioning System é um sistema de superfície de recondicionamento de Modelos Digitais de Elevação. 0 sistema ajusta a elevação da superfície do MDE para ser consistente com uma cobertura de vetor. A cobertura do vetor pode ser um córrego ou cobertura de linha do cume. 
A base de dados utilizada para aplicação da função DEM Reconditioning foi o Modelo Digital de Elevação (MDE), projeto TOPODATA - Banco de dados Geomorfométrico do Brasil (INPE), disponível em: www.dpi.inpe/topodata/, e a rede de drenagem disponível no Atlas Digital sobre Recursos Hídricos do Estado de Sergipe - Versão 2013.3.

A partir destes dados é apresentado o delineamento da bacia hidrográfica que, segundo Porto \& Porto (2008), é uma área de captação natural da água de precipitação que faz convergir o escoamento para um único ponto de saída denominado exutório. São também determinadas as suas características físiográficas relacionadas aos parâmetros morfométricos (planimétricos, altimétricos, morfológicos e hidrológicos).

\section{OBJETIVOS}

O presente estudo teve como objetivo analisar os parâmetros morfométricos da bacia hidrográfica do rio Jacarecica a partir do Modelo Digital de Elevação (MDE), projeto TOPODATA, utilizando-se das ferramentas do ArcHydro, com aplicação do recondicionamento do MDE e o preenchimento de depressões. Desta forma, buscou-se ainda correlacionara utilização da função DEM Reconditioning a rede de drenagem editada a partir das imagens SPOT 5, através do método de interpretação visual.

\section{MATERIAIS E MÉTODOS}

\subsection{MATERIAIS}

A pesquisa fez uso de material cartográfico, imagens de Radar, equipamentos e softwares. Como base cartográfica, utilizou-se o Atlas Digital sobre Recursos Hídricos do Estado de Sergipe - Versão 2013.3, arquivos shapefiles: rede de drenagem da bacia hidrográfica do rio Jacarecia, divisão climática, geologia, geomorfologia e solos. Foram obtidas imagens de Radar SRTM, provenientes do projeto TOPODATA, através do site do INPE: www.dpi.inpe/topodata/, folha 10s375, formato GRD.

A Missão Topográfica Radar Shuttle (SRTM) obteve dados de elevação com uma escala próxima à global para gerar a mais completa base de dados topográficos digitais de alta-resolução da Terra. O SRTM consistiu de um sistema de radar especialmente modificado que voou acoplado ao Ônibus Espacial Endeavour durante os 11 dias da missão STS- 9, em Fevereiro de 2000. Os dados foram distribuidos em uma grade com arco de 1 segundo (resolução de 30 metros) para os EUA e com um arco de 3 segundos (resolução de 90 metros) para o resto do mundo da latitude de $56^{\circ} \mathrm{S}$ até a de $60^{\circ} \mathrm{N}$.

Para realização do estudo utilizou-se dois pacotes de softwares, um comercial (ArcGis), licenciado para Secretaria de Estado do Meio Ambiente dos Recursos Hídricos do Estado de Sergipe e outro de domínio público (ArcHydro Tools), desenvolvido no Centro de Pesquisas em Recursos Hídricos (Center for Research in Water Resources - CRWR) da University of Texas - Austin ( EUA) e distribuído gratuitamente pela ESRI: ftp site: ftp.esri.com.

\subsection{LOCALIZAÇÃO E CARACTERIZAÇÃo}

\subsubsection{LOCALIZAÇÃO}

O estado de Sergipe, menor unidade federativa, com uma área de $21.910,35 \mathrm{~km}^{2}$, está inserido na porção leste da região do nordeste brasileiro, situa-se entre os paralelos $9^{\circ} 30^{\prime}$ e $11^{\circ} 34^{\prime}$ de latitude sul e os meridianos $36^{\circ} 24^{\prime}$ e $38^{\circ} 14^{\prime}$ de longitude oeste.

0 estado de Sergipe é formado por 08 (oito) bacias hidrográficas, sendo 3 (três) de rios federais - rios São Francisco, Vaza Barris e Real - e outras 5 (cinco) de rios estaduais - rios Sapucaia, Japaratuba, Sergipe, Caueira/Abais e Piauí. É reconhecido que, dentre as bacias hidrográficas de Sergipe, a de maior relevância, tendo em vista os aspectos de ordem social, econômica, populacional e ambiental, é a do rio Sergipe.

Em outra abordagem, o estado de Sergipe é dividido em 27 sub-bacias hidrográficas, classificadas como unidades de planejamento, dentre as quais, destacamos a bacia hidrográfica do rio Jacarecica, localizada na porção centro-oeste da bacia hidrográfica do rio Sergipe, situando-se entre os paralelos $10^{\circ} 32^{\prime}$ e $10^{\circ}$ $46^{\prime}$ de latitude sul e os meridianos $37^{\circ} 12^{\prime}$ e $37^{\circ} 29^{\prime}$ de longitude oeste (Figura 1). 
Figura 1 - Localização da Bacia Hidrográfica do Rio Jacarecica.

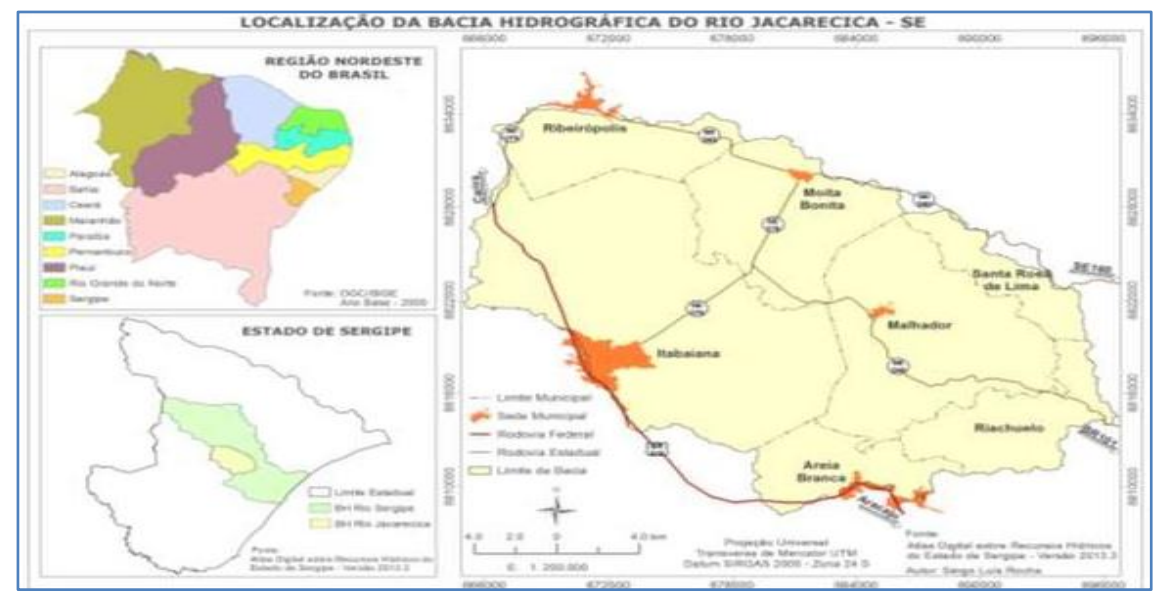

As unidades de planejamento definidas no Plano Estadual de Recursos Hídricos do estado de Sergipe, elaborado em 2012, foram geradas a partir das informações de direção de fluxo e área acumulada obtidas da topografia da região representada em meio digital pelo Modelo Numérico do Terreno (MNT). Além da utilização das características físicas para delimitação das unidades, consideraram-se as informações de disponibilidade hídrica associadas aos aspectossocioeconômicos.

A primeira etapa foi baseada na divisão climática, na precipitação e nos mapas de geologia, de aqǘferos e de geomorfologia. Em seguida, foram confrontadas informações de disponibilidade hídrica com as unidades delineadas e; por último, considerou-se a importância de afluentes com grandes reservatórios, áreas de irrigação e indústrias. Seguindo estes critérios, foram identificadas 27 unidades de planejamento (Figura2).

Figura 2 - Unidades de Planejamento do Estado de Sergipe

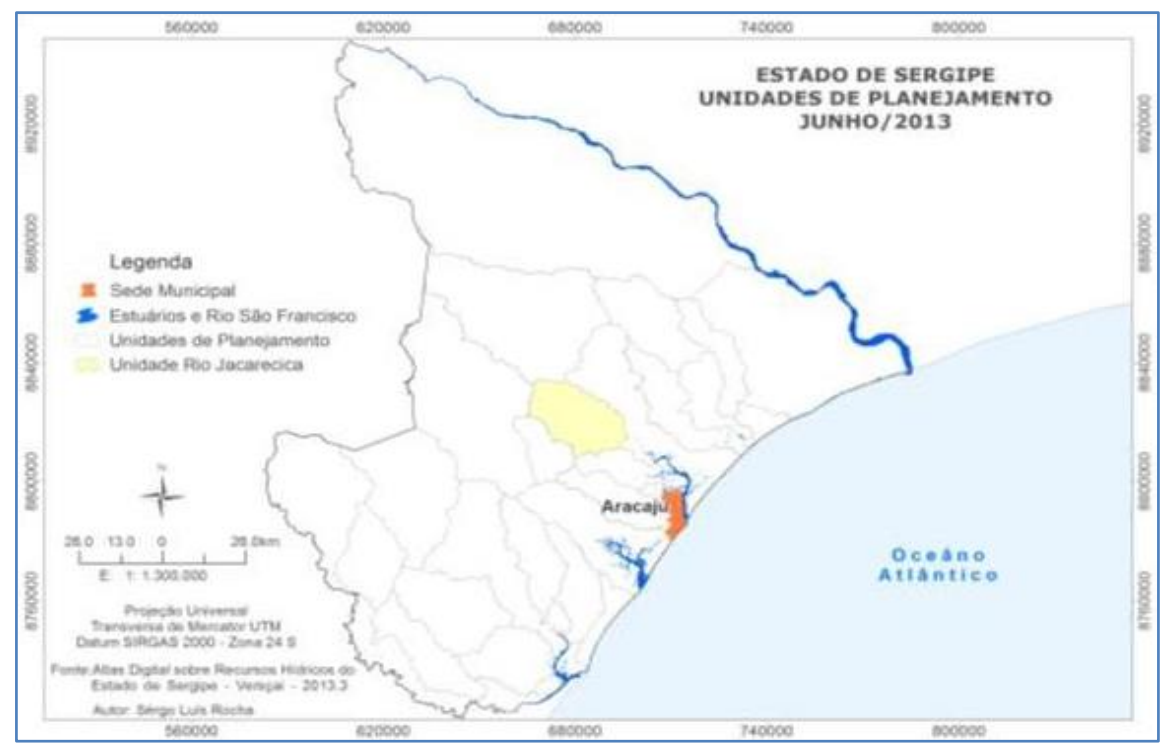




\subsection{CARACTERIZAÇ̃̃o}

\subsubsection{ZONASCLIMÁTICAS}

De acordo com o Plano Estadual de Recursos Hídricos (2012), a bacia hidrográfica do rio Jacarecica apresenta 3 (três) zonas climáticas, a saber: litoral úmido com área de 247,12 km²; agreste com área de $254,58 \mathrm{~km}^{2}$ e semi-árido com área de $0,29 \mathrm{~km}^{2}$ (Figura 3).

Figura 3 - Zonas Climáticas da Bacia Hidrográfica do Rio Jacarecica.

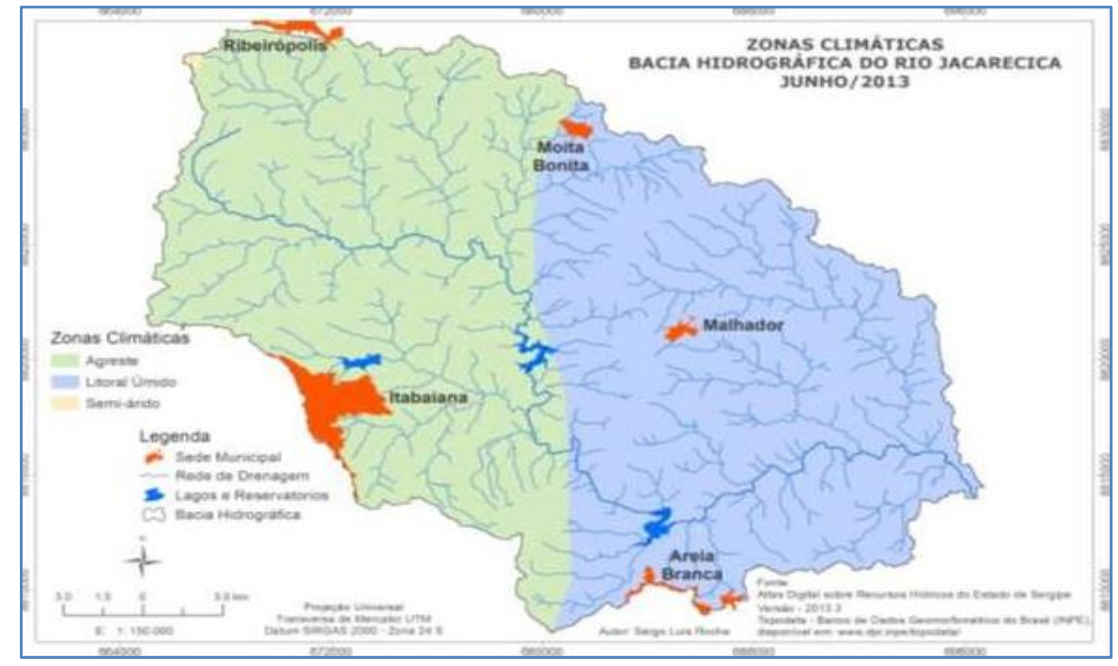

\subsubsection{UNIDADES GEOLÓGICAS}

O estado de Sergipe está localizado na região limítrofe das Provincias São Francisco; Borborema e a Costeira e Margem Continental (Almeida, 1977). De acordo com o autor, a Provincia São Francisco corresponde, em extensão e limites, ao Cráton do São Francisco. A Provincia da Borborema está representada pela Faixa de Dobramentos Sergipana, situada entre o limite nordeste do Cráton do São Francisco e o Maciço Pernambuco-Alagoas. A Provincia Costeira e Margem Continental têm suas extensões submersas na margemcontinental.

A geologia da bacia do rio Jacarecica constitui-se dos seguintes terrenos tectono- estratigráficos: Embasamento Gnássico, onde se encontra o complexo gnássico- migmatitico do Domo de Itabaiana; Faixa de Dobramentos Sergipana, Domínio Vaza- Barris, onde se encontra o Grupo Míaba composto pelas formações Itabaiana, Ribeirópolis e Jacoca; e Bacia Sedimentar Sergipe - Alagoas.

Conforme SERGIPE (2012), cerca de 50\% da área da bacia é coberta pelo Complexo Itabaiana/Simão Dias. Na seqüência, destacam-se as unidades geológicas Itabaiana; Ribeirópolis; Barreiras; Angico; Frei Paulo - Unidade 1; Taquari/Maruim; Frei Paulo - Unidade 2 e Olhos d’Água (Figura 4). 
Figura 4 - Unidades Geológicas da Bacia Hidrográfica do Rio Jacarecica.

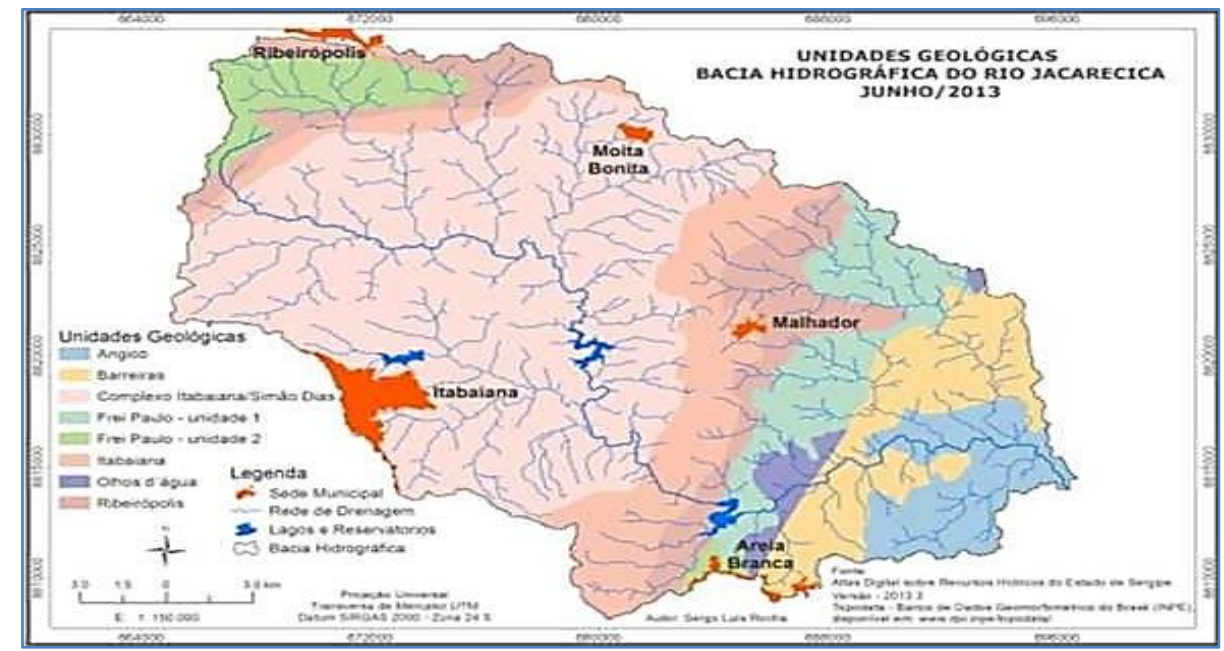

\subsubsection{GEOMORFOLOGIA}

O mapa temático elaborado para a geomorfologia da bacia hidrográfica do rio Jacarecica apresenta as Unidades Geomorfológicas (terceiro nível taxonômico). De acordo com o Manual Técnico de Geomorfologia (IBGE, 2009), as unidades geomorfológicas são definidas como um arranjo de formas altimétrica e fisionomicamente semelhantes em seus diversos tipos de modelados. Assim sendo, cada unidade geomorfológica evidencia seus processos originários, formações superficiais e tipos de modelados diferenciados dos demais.

O relevo de Sergipe é pouco movimentado, caracterizado por um modelado suave de áreas planas e altitudes modestas com elevações denominadas de serras que constituem os pontos mais elevados do Estado.

As bacias pertencentes ao estado de Sergipe possuem praticamente os mesmos componentes geomorfológicos. De montante para jusante, apresentam os compartimentos identificados como Pediplano Sertanejo, Serras Residuais, Tabuleiros Costeiros e Superfície dos Rios (Figura 5).

Figura 5 - Unidades Geomorfológicas da Bacia Hidrográfica do Rio Jacarecica.

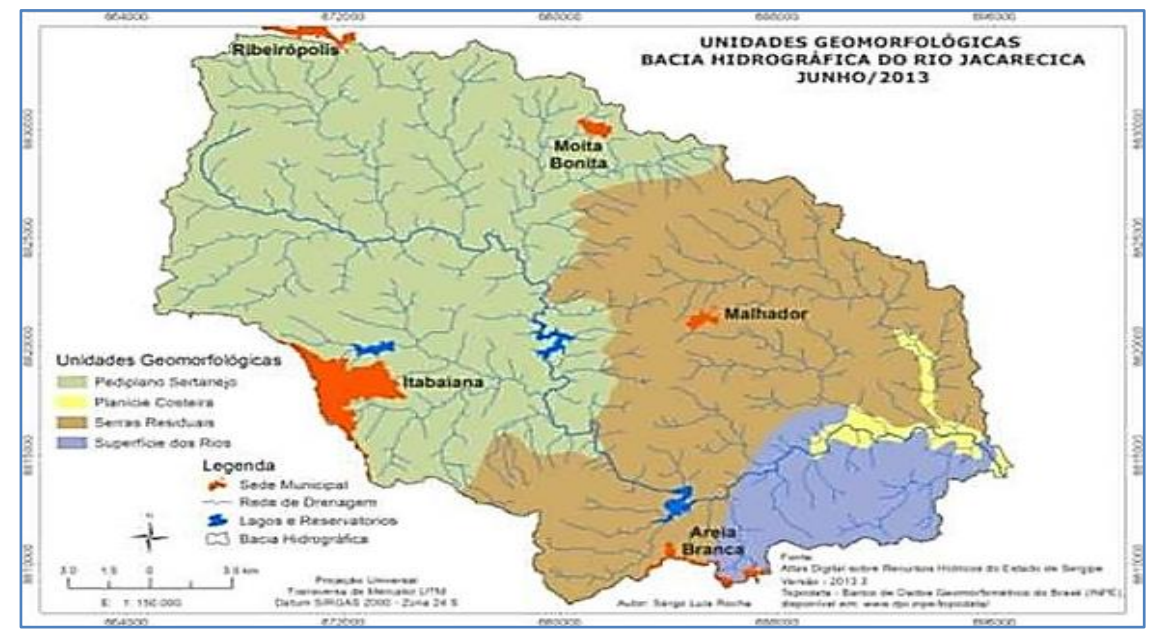




\subsubsection{PEDOLOGIA}

A caracterização dos principais grupos de solos sergipanos foi feita com base no Sistema Brasileiro de Classificação de Solos (EMBRAPA, 2006), levando-se em consideração potencialidades e limitações, riscos de degradação e potencial para irrigação.

A bacia hidrográfica do rio Jacarecica apresenta cinco classes de solos, com destaque para Luvissolos; Planossolos e Neossolos. O primeiro compreende solos minerais, não hidromórficos, com argila de atividade alta. O segundo é um solo pouco profundo, impermeável e ocorre tipicamente em áreas de cotas baixas, planas a suave onduladas, o que facilita a motomecanização agrícola. 0 terceiro são solos constituídos por material orgânico pouco espesso que não apresentam grandes alterações em relação ao material originário. (Figura 6).

Figura 6 - Solos da Bacia Hidrográfica do Rio Jacarecica.

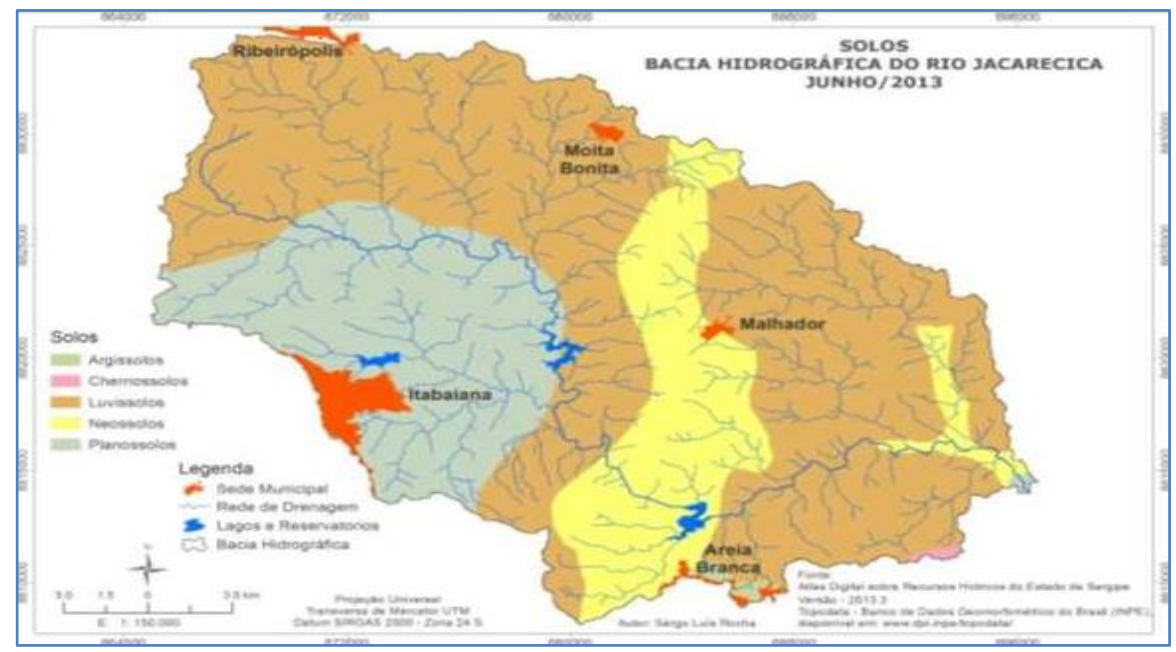

\section{PROCEDIMENTO METODOLÓGICO}

A metodologia utilizada para a caracterização morfométrica alicerçou-se na descrição dos variados aspectos da análise morfométrica de bacias hidrográficas, os quais podem ser encontrados nos estudos desenvolvidos por Horton (1932), Freitas (1999), Schumm (1957) e Christofoletti (1960) dentre outros.

As variáveis morfológicas da bacia foram obtidas por meio da imagem SRTM, MDE Topodata, geradas a partir dos dados trabalhados com ferramentas de geoprocessaamento, software ArcGis v. 10.0, aplicativo ArcHydro Tools v. 10.0 que forneceram os dados relativos aos índices e parâmetros desenvolvidos. Neste estudo, os parâmetros morfométricos foram divididos em: parâmetros básicos (planimétricos e altimétricos) e parâmetros derivados (morfológicos ehidrológicos).

\subsection{PARÂMETROS BÁSICOS PLANIMÉTRICOS}

Entendem-se como planimétricos todos os parâmetros que estão correlacionados a geometria da bacia hidrográfica, tais como sua área e perímetro, bem como todas as variáveis que são extraídas diretamente da rede de drenagem.

\section{2 ÁREA E PERÍMETRO DA BACIA}

Conceituada como toda área drenada pelo conjunto fluvial, projetada em um plano horizontal (Christofoletti, 1969). É representada pela letra (A) e sua extensão é expressa em quilômetro quadrado $\left(\mathrm{km}^{2}\right)$. 0 perímetro da bacia hidrográfica corresponde ao comprimento da linha imaginária ao longo do divisor de águas (Tonello, 2005 in Teodoro et al, 2007). É representado pela letra (P) e sua extensão é expressa em quilômetro $(\mathrm{km})$. 


\subsection{COMPRIMENTO DO EIXO DA BACIA}

Representa a medida do comprimento da linha que une a foz até o ponto extremo da bacia, localizado sobre a linha do divisor topográfico, que segue a direção do vale principal, dividindo o perímetro em duas partes iguais (Schumm, 1956). É representado pela letra (C) e sua extensão é expressa em quilômetro(km).

\subsection{MAIOR LARGURA DA BACIA}

É a maior dimensão linear que a bacia apresenta num eixo transversal ao vale por ela formado, sendo medida transversalmente ao maior comprimento (Strahler, 1957). É representado pela letra (I)e sua extensão é expressaem quilômetro.

\subsection{COMPRIMENTO DA REDE DE DRENAGEM}

Corresponde ao comprimento total de todos os rios de uma bacia hidrográfica (França et al, 1993). É representado pela sigla (Lt) e sua extensão é expressa em quilômetro (km).

\subsection{COMPRIMENTO DOS CANAIS POR ORDEM}

O comprimento dos canais por ordem corresponde ao comprimento dos canais ordenados de uma bacia hidrográfica. É representado pela sigla (Ltn) e sua extensão é expressa em quilômetro (km).

\subsection{ORDENAMENTO DA BACIA}

A hierarquização dos canais seguiu o critério proposto por (Strahler, 1957), em que os canais sem tributários são de primeira ordem. Os canais de segunda ordem são os que se originam da confluência de dois canais de primeira ordem, podendo ter afluentes de primeira ordem. Os canais de terceira ordem originam-se da confluência de dois canais de segunda ordem, podendo receber afluentes de segunda e primeira ordens, e assimsucessivamente.

De acordo com (Christofoletti, 1969), cada segmento de ordem superior drena uma área cada vez maior à medida que aumenta a ordem dos canais. Assim sendo, identificando-se as quantidades de bacias para cada ordem, pode-se calcular a área média das bacias de determinada ordem. Ressalta-se que a junção de um canal de dada ordem a um canal de ordem superior não altera a ordem deste.

\subsection{COMPRIMENTO DO CANAL PRINCIPAL}

O comprimento do canal principal é medido com curvímetro, acompanhando as sinuosidades do rio principal, da foz até a nascente (Silva, 2006). É representado pela sigla (Cp) e sua extensão é expressa em quilômetro $(\mathrm{km})$. Para determinação deste parâmetro abriu-se, no ArcGis, os arquivos correspondentes a bacia hidrográfica; rede de drenagem e curvas de nível $(30 \mathrm{~m})$. Em seguida, uniu-se a partir do canal de maior ordem,os canais de menor ordem até se atingir o ponto mais alto da bacia. Outro aspecto a ser ressaltado é que o processo levou em consideração as áreas de drenagens de jusante a montante; ou seja, para confluências relevantes, calculou-se a área de drenagem.

\subsection{COMPRIMENTO DO CANAL REBATIDO}

Este parâmetro pode ser definido como o segmento retilíneo que une a foz do canal principal ao seu ponto extremo, localizado na cabeceira da bacia de drenagem. É representado pela sigla (Rb) e sua extensão é expressa em quilômetro $(\mathrm{km})$. Para determinação deste parâmetro abriu-se, no ArcGis, os arquivos correspondentes a bacia hidrográfica e o curso d água principal. Em seguida, uniram-se as extremidades do canal principal. 


\subsection{NÚMERO DE CANAIS DA BACIA}

É o número de segmentos de rios que foi obtido contando-se os canais existentes em toda bacia (França et al, 1993). É adimensional e é representado pela sigla (Nt).

\subsection{NÚMERO DE CANAIS DA BACIA POR ORDEM}

É o número de segmentos de rios computados em cada ordem de drenagem. 0 símbolo w é utilizado para uma dada ordem de ramificação (França, et al, 1993). É adimensional e é representado pela sigla (Nwn).

\subsection{PARÂMETROS BÁSICOS ALTIMÉTRICOS}

Entendem-se como altimétricos todos os parâmetros que estão associados às feições altimétricas da bacia hidrográfica, como por exemplo, maior e menor altitude, amplitude altimétrica, dentre outros.

Os indicadores altimétricos de uma bacia hidrográfica podem ser verificados através das referências de nível; pontos cotados; curvas de nível ou através das imagens SRTM (Shuttle Radar Topography Mission). A variação da altitude associada com outros fatores influencia o comportamento da bacia.

\subsection{MENOR E MAIOR ALTITUDE DA BACIA}

O histograma da imagem SRTM apresenta algumas estatísticas referentes à imagem, dentre elas a altitude mínima (Hmin) e máxima (Hmax) da bacia hidrográfica. Sua extensão é expressa, geralmente, em metro $(\mathrm{m})$.

\subsection{ALTITUDE MÉDIA DA BACIA}

O histograma da imagem SRTM apresenta algumas estatísticas referentes à imagem, dentre elas a altitude média (Hmed). Sua extensão é expressa, geralmente, em metro (m).

Menor e Maior Altitude do CanalPrincipal

Determinou-se a menor altitude do canal principal (HCmin) e maior altitude do canal principal (HCmax), através da sobreposição do vetor representativo do canal principal na imagem SRTM que recobre a bacia hidrográfica. Em seguida, clicou-se no pixel correspondente ao ponto do canal com altitude mais baixa e mais alta. Sua extensão é expressa, geralmente, em metro (m).

\subsection{DISTRIBUIÇÃO HIPSOMÉTRICA DA BACIA}

Para o cálculo da distribuição hipsométrica da bacia, ativa-se a imagem correspondente a este parâmetro e em seguida abre-se a caixa indicadora das propriedades da imagem que representa a distribuição de pixels por intervalo hipsométrico.

\subsection{DISTRIBUIÇÃO CLINOMÉTRICA DA BACIA}

Para o cálculo da distribuição clinométrica da bacia, ativa-se a imagem correspondente a este parâmetro e em seguida abre-se a caixa indicadora das propriedades da imagem que representa a distribuição de pixels por intervalo clinométrico.

\subsection{DECLIVIDADE MÉDIA DA BACIA}

A magnitude dos picos de enchente e infiltração de água, trazendo, como conseqüência, maior ou menor grau de erosão, depende da declividade média da bacia hidrográfica (que determina maior ou menor escoamento da água superficial), associada à cobertura vegetal, tipo de solo e tipo de uso da terra (Rocha \& Kurtz, 2001). 
Para se determinar a declividade média da bacia hidrográfica, ativa-se a imagem que representa a declividade original, antes que tenha sido realizado o processo de reclassificação. Em seguida, abre-se a caixa do histograma e verifica-se a declividade média da bacia em porcentagem (\%).

\subsection{PARÂMETROS DERIVADOS MORFOLÓGICOS}

Entendem-se como derivados morfológicos todos os parâmetros associados às feições planialtimétricas da bacia hidrográfica e que sejam determinados a partir de formulações envolvendo parâmetros básicos.

\section{Amplitude Altimétrica da Bacia}

A amplitude altimétrica $(\Delta \mathrm{H})$ é a diferença entre a maior e a menor altitude da bacia hidrográfica, expressa em metro (Strahler, 1975).

Este parâmetro é determinado pela seguinte expressão:

$$
\Delta \mathrm{H}=\mathrm{Hmax}-\mathrm{Hmin}
$$

Onde, $\Delta \mathrm{H}$ é a amplitude altimétrica da bacia, Hmax é a cota máxima e Hmin é a cota mínima.

Amplitude Altimétrica do CanalPrincipal

A Amplitude Altimétrica do Canal Principal da bacia hidrográfica é representada pela sigla $(\Delta \mathrm{HCp})$ e sua extensão é expressa em metro (m).

Esta variável é determinada pela seguinte expressão:

$$
\Delta \mathrm{HCp}=\mathrm{HCpmax}-\mathrm{HCpmin}
$$

Onde, $\triangle$ HCp é a amplitude altimétrica do canal principal, HCpmax é a altitude máxima e HCpmin é a altitude mínima.

\subsection{DENSIDADE DE DRENAGEM}

A densidade de drenagem é a razão entre o comprimento total do sistema de drenagem e a área da bacia hidrográfica (Christofoletti, 1969). É representada pela sigla (Dd) e sua extensão é expressa em quilômetro por quilômetro quadrado $\left(\mathrm{km} / \mathrm{km}^{2}\right)$.

Para Horton, além do regime de chuvas e do relevo, dois outros fatores determinam a densidade de drenagem, a capacidade de infiltração do solo e a resistência inicial à erosão.

De acordo com Villela e Mattos (1975), a densidade varia de 0,5 km/ $\mathrm{km}^{2}$, em bacias com drenagem pobre, a 3,5 ou mais, para bacias excepcionalmente bem drenadas (Villela e Mattos, in Cardoso,2006).

Esta variável é determinada pela seguinte expressão:

$$
\mathrm{Dd}=\mathrm{Lt} / \mathrm{A}
$$

Onde, Dd é a densidade de drenagem, Lt é o comprimento total de todos os canais e A é a área da bacia hidrográfica.

\subsection{DENSIDADE HIDROGRÁFICA DA BACIA}

A densidade de rios é a relação existente entre o número de rios ou cursos d’água e área da bacia hidrográfica (Alcântara et al, 2005). Segundo Christofoletti (1969), a finalidade deste índice é comparar a freqüência ou a quantidade de cursos d’água existentes em uma área de tamanho padrão, como 
exemplo o quilômetro quadrado. É representada pela sigla (Dh) e sua extensão é expressa pelo inverso do quilômetro quadrado $\left(\mathrm{km}^{-}{ }^{2}\right)$.

A densidade hidrográfica da bacia é determinada pela seguinte expressão: $\mathrm{Dh}=\mathrm{Nt} / \mathrm{A}$

Onde, Dh é a densidade de rios da bacia, Nt é o número total de todos os canais e $\mathrm{A}$ a área da bacia.

\subsection{COMPRIMENTO MÉDIO DA REDE DE DRENAGEM}

O comprimento médio de segmentos de rios é obtido pela divisão do comprimento total de todos os canais e o somatório dos canais da bacia hidrográfica. É representado pela sigla (Lm) e sua extensão é expressa em quilômetro $(\mathrm{km})$.

Este parâmetro é determinado pela seguinte expressão:

$$
\mathrm{Lm}=\mathrm{Lt} / \mathrm{Nt}
$$

Onde, Lm é o comprimento médio da rede de drenagem, Lt é o comprimento total de todos os canais e Nt é o somatório dos canais da bacia hidrográfica.

\section{Extensão do Percurso Superficial}

A extensão do percurso superficial representa a distância média percorrida pelas enxurradas entre o interflúvio e o canal permanente, esta variável independente afeta tanto o desenvolvimento hidrológico como o fisiográfico das bacias hidrográficas. É representada pela sigla (Eps) e sua extensão é expressa em quilômetro $(\mathrm{km})$.

Esta variável é determinada pela seguinte expressão:

$$
\text { Eps }=1 / 2 \mathrm{Dd}
$$

Onde, Eps é a extensão do percurso superficial, Dd é a densidade hidrográfica da bacia.

\subsection{RAZÃO DE TEXTURA DA BACIA}

A razão de textura da bacia é calculada através da relação entre o número total de rios da bacia e seu respectivo perímetro (Silva, 2006). É representada pela sigla (T) e sua extensão é expressa pelo inverso do quilômetro $\left(\mathrm{km}^{-1}\right)$.

Esta variável é determinada pela seguinte expressão:

$$
\mathrm{T}=\mathrm{Nt} / \mathrm{P}
$$

Onde, T é a razão de textura da bacia, Nt é o número total de rios da bacia e P é o perímetro.

\subsection{COEFICIENTE DE COMPACIDADE DA BACIA}

O coeficiente de compacidade relaciona o perímetro da bacia e a circunferência do círculo, cuja área é igual à da bacia de drenagem (Villela \& Mattos, 1975). Este parâmetro é um número adimensional que varia com a forma da bacia, independente de seu tamanho. Assim, quanto mais irregular for a bacia, maior será o coeficiente de compacidade.

Portanto, um coeficiente mínimo igual a unidade corresponderia a uma bacia circular, com alta propensão a enchentes e, para uma bacia alongada, seu valor é significativamente superior a 1 , indicando menor propensão a enchentes, valores superiores a 1,47 caracterizam bacias não sujeitas a enchentes. 
Este parâmetro é determinado pela seguinte expressão:

$$
\mathrm{Kc}=0,28 \times \mathrm{P} / \sqrt{\mathrm{A}}
$$

Onde, Kc é o coeficiente de compacidade, P é o perímetro da bacia hidrográfica e A é a área da bacia.

\subsection{FATOR DE FORMA DA BACIA}

De acordo com Villela \& Mattos (1975) o fator de forma é a razão entre a largura média e o comprimento do eixo (ou axial) da bacia (da foz ao ponto mais distante da bacia). A largura média é obtida dividindose a área pelo comprimento do eixo.

$\mathrm{O}$ fator de forma indica maior ou menor tendência a enchentes; pois para bacias com fator de forma baixo há uma possibilidade menor de uma chuva intensa cobrir toda a sua extensão do que em uma bacia com mesma área e fator de forma maior (Villela \& Mattos, 1975). De acordo com esses autores, bacias com valores de fator de forma inferiores a 0,439 indicam menor sujeição a enchentes.

Este parâmetro é determinado pela seguinte expressão:

$$
\mathrm{F}=\mathrm{A} / \mathrm{L}^{2}
$$

Onde, F é o fator de forma, A é a área da bacia hidrográfica e L é o comprimento do eixo da bacia.

\subsection{5 ÍNDICE DE CIRCULARIDADE}

Similarmente ao coeficiente de compacidade, o índice de circularidade tende para a unidade à medida que a bacia se aproxima da forma circular e diminui ao passo que a forma se torna alongada (Cardoso et al, 2006). É representado pela sigla (IC) e sua extensão é expressa em metro(m).

Segundo Alves \& Castro (2003), índice de circularidade superior a 0,51 revela que a bacia tem tendência circular favorecendo o processo de inundação (cheias rápidas). Conquanto, índice de circularidade inferior a 0,51 a bacia se apresenta com tendência alongada, favorecendo desta forma o escoamento.

Este parâmetro é determinado pela seguinte expressão:

$$
\mathrm{IC}=12,57 \times \mathrm{A} / \mathrm{P}^{2}
$$

Onde, IC é o índice de circularidade, A é a área da bacia e P é o perímetro da bacia hidrográfica.

\subsection{RAZÃO DE RELEVO DA BACIA}

A razão de relevo indica a declividade geral ou declive total da superfície da bacia hidrográfica (Strahler, 1957).

Esta variável é determinada pela seguinte expressão:

$$
\mathrm{Rr}=\Delta \mathrm{H} / \mathrm{C}
$$

Onde, $\mathrm{Rr}$ é a razão de relevo, $\Delta \mathrm{H}$ é a amplitude altimétrica e $\mathrm{C}$ é o comprimento do eixo maior da bacia hidrográfica.

Razão de Relevo Relativo da Bacia 
A razão de relevo relativo corresponde a relação entre amplitude altimétrica e o perímetro da bacia.

Esta variável é determinada pela seguinte expressão:

$$
\operatorname{Rrl}=\Delta \mathrm{H} / \mathrm{P}
$$

Onde, $\mathrm{Rrl}$ é a razão de relevo relativo, $\Delta \mathrm{H}$ é a amplitude altimétrica e $\mathrm{P}$ é o perímetro da bacia hidrográfica.

\subsection{COEFICIENTE DE RUGOSIDADE DA BACIA}

0 coeficiente de rugosidade é determinado pelo produto entre a densidade de drenagem e a declividade média (Rocha \& Kurtz, 2001). Este parâmetro indica o potencial do uso da terra na bacia hidrográfica.

Este parâmetro é determinado pela seguinte expressão:

$$
\mathrm{RN}=\mathrm{Dd} / \mathrm{DCmed}
$$

Onde, RN é o coeficiente de rugosidade, Dd é a densidade de drenagem da bacia e DCmed é a declividade média da bacia hidrográfica.

\subsection{DECLIVIDADE DO CANAL PRINCIPAL}

Segundo Tonello (2005), a declividade do canal principal é fator relevante na análise morfométrica, uma vez que interfere na velocidade do escoamento da água no curso. É representado pela letra (S) e é expressa em metro por quilômetro $(\mathrm{m} / \mathrm{km})$.

Esta variável é determinada pela seguinte expressão:

$$
\mathrm{S}=\Delta \mathrm{HCp} / \mathrm{Cp}
$$

Onde, $\mathrm{S}$ é a declividade do canal principal, $\triangle \mathrm{HCp}$ é a amplitude altimétrica do canal e Cp é o comprimento do canal principal.

\subsection{PARÂMETROS DERIVADOS HIDROLÓGICOS}

Entendem-se como derivados hidrológicos todos os parâmetros que estão

associados às feições hidrológicas da bacia hidrográfica e que sejam determinados a partir de formulações envolvendo parâmetros básicos.

\subsection{COEFICIENTE DE MANUTENÇÃO}

O coeficiente de manutenção fornece a área mínima necessária para manutenção de um metro de canal de escoamento (Schumm, 1956). É representado pela sigla $(\mathrm{Cm})$ e sua extensão é expressa em metro quadrado $\left(\mathrm{m}^{2}\right)$.

Este parâmetro é determinado pela seguinte expressão:

$$
\mathrm{Cm}=1 / \mathrm{Dd} \times 1.000
$$


Onde, $\mathrm{Cm}$ é o coeficiente de manutenção e Dd é a densidade de drenagem da bacia hidrográfica.

\subsection{1 ÍNDICE DE SINUOSIDADE}

0 índice de sinuosidade descreve o grau de tortuosidade dos cursos d água, sendo um fator controlador da velocidade de escoamento das águas (Villela \& Mattos, 1975). É representado pela sigla (Is) é adimensional ou expresso em percentual (\%).

De acordo com Alves \& Castro (2003), índice de sinuosidade igual a um revela que o canal de drenagem tende a ser retilíneo. Conquanto, índice de sinuosidade superior a dois revela que o canal de drenagem tende a ser tortuoso e valores intermediários indicam formas transicionais.

0 valor percentual superior a 60 corresponde a um rio classe $V$, muito sinuoso conforme classificação de Christofolleti.

Este parâmetro é determinado pela seguinte expressão:

$$
\mathrm{Is}=\mathrm{Cp} / \mathrm{Rb}
$$

Onde, Is é o índice de sinuosidade da bacia, $\mathrm{Cp}$ é o comprimento do canal principal e $\mathrm{Rb}$ é o comprimento do canal rebatido.

\subsection{TEMPO DE CONCENTRAÇÃO}

O tempo de concentração pode ser definido como o tempo necessário para que toda área da bacia considerada contribua com o escoamento na seção de deságüe (Filzikowski et al, 2008). É representado pela sigla (Tc) e é expresso em horas.

Este parâmetro é determinado pela seguinte expressão:

$$
\mathrm{Tc}=4 \sqrt{\mathrm{A}}+1,5 \mathrm{Cp} / 0,8 \sqrt{\Delta \mathrm{H}}
$$

Onde, Tc é o tempo de concentração da bacia, A é a área da bacia, Cp é o comprimento do canal principal e $\Delta \mathrm{H}$ é a amplitude altimétrica da bacia hidrográfica.

\section{RESULTADOS E DISCUSSÕES}

A análise dos parâmetros planimétricos permitiu constatar que a área total da bacia do rio Jacarecica é de $507,29 \mathrm{~km}^{2}$ e o perímetro $152,61 \mathrm{~km}$. A Área de drenagem da bacia é uma das variáveis mais importantes, visto que quase todas as outras características estão corelacionadas.

Segundo Schumm (1956), a área da bacia aumenta exponencialmente com o aumento da ordem de ramificação dos rios e varia em conformidade com a relação infiltração/deflúvio. Considerando-se que a drenagem de maior ordem identificada na bacia hidrográfica do rio Jacarecica foi de quinta ordem, fica estabelecido que a referida bacia também é de Quinta Ordem, de acordo com a metodologia proposta por Strahler (1957), que modificou o sistema de classificação de rios de Horton (1932).

As altitudes na bacia variam de 04 metros, na área de confluência do rio Jacarecica com o rio Sergipe, até 657 metros no topo mais alto (Figura 7). As maiores altitudes estão concentradas na faixa intermediária da bacia, um pouco mais ao sul, no sentido Sudoeste-Nordeste. Nesta faixa, encontra-se o domo de Itabaiana e as serras residuais, representadas pelas serras Cajueiro; Comprida e Itabaiana. 
Figura 7 - Hipsometria da Bacia Hidrográfica do Rio Jacarecica.

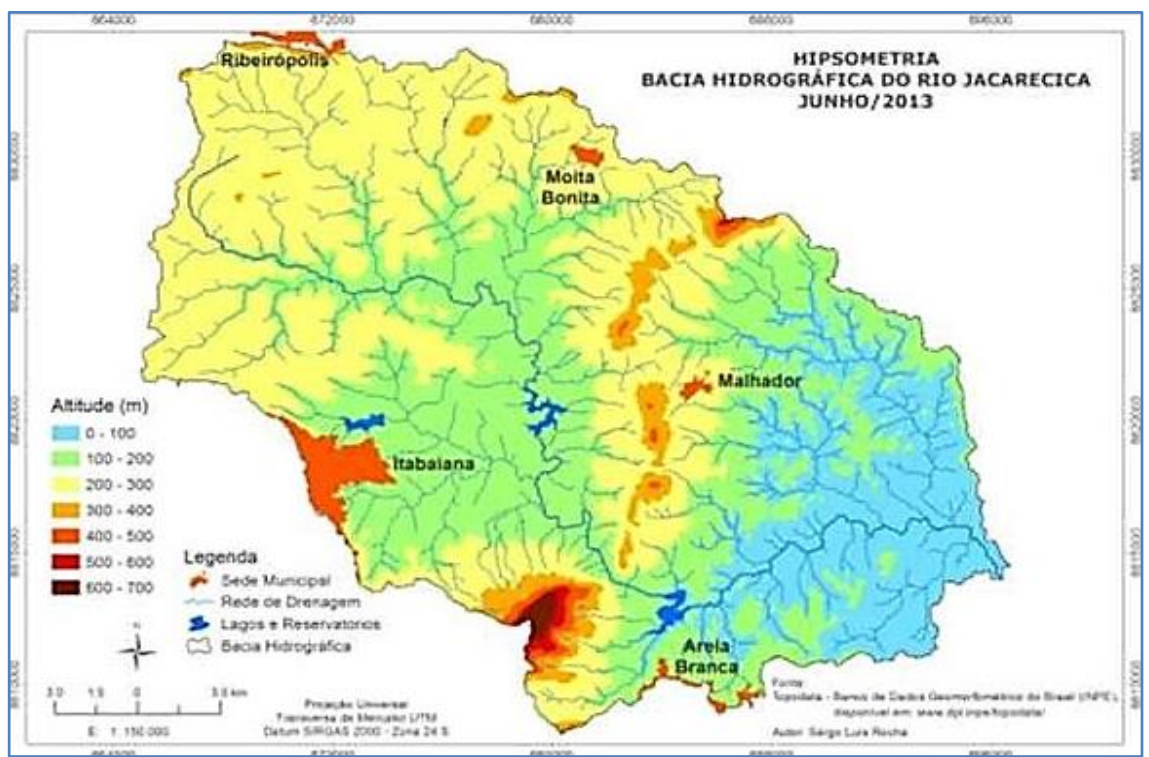

A determinação das classes de declividade da bacia baseou-se nos intervalos de porcentagem propostos por Ramalho Filho e Beek (1995), (Figura 8). Esses intervalos são definidos pelos autores conforme o grau de limitação de uso do solo em função da susceptibilidade à erosão.

Para o cálculo das classes de declividade utilizamos a função slope em que a estimativa da declividade se baseia na análise dos desníveis entre pixels vizinhos.

Observa-se que cerca de $84 \%$ da área da bacia apresenta relevo plano a moderadamente ondulado. 0 relevo ondulado corresponde a $12 \%$ da área da bacia, enquanto que o relevo fortemente ondulado corresponde a um pouco mais de $3 \%$, este tipo de relevo concentra-se na porção sudeste da bacia, sentido noroeste-nordeste, com pequenas manchas ao norte.

Figura 8 - Declividade da Bacia Hidrográfica do Rio Jacarecica.

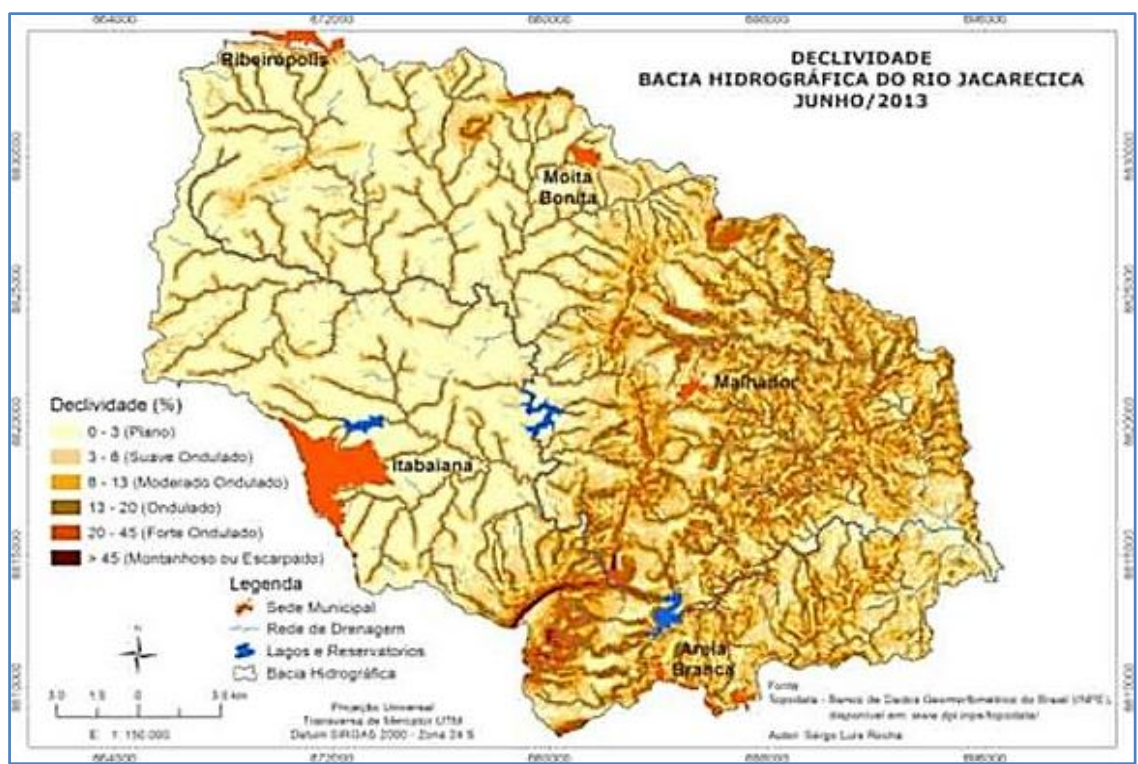


A análise das variáveis morfométricas referentes ao coeficiente de compacidade, fator de forma e índice de circularidade comprovam a forma alongada da bacia. Para os parâmetros fator de forma e índice de circularidade a bacia apresentou os valores de 1,23 e 0,27, respectivamente. Enquanto que, para o coeficiente de compacidade a bacia apresentou o valor de 1,90. Estes valores caracterizam o aspecto alongado da bacia, como também indicam que a bacia é pouco propensa a enchentes e inundações.

De acordo com Christofoletti (1969), a densidade de drenagem é um parâmetro físico fundamental na susceptibilidade entre bacias, pois relaciona o comprimento total da rede de drenagem (Lt) e a área (A) e; assim sendo, quanto maior for o valor do comprimento da rede drenagem maior será o perigo de erosão.

A bacia apresenta uma densidade de drenagem de $1.30 \mathrm{~km} / \mathrm{km}^{2}$ (Figura 9). De acordo com Villela e Mattos (1975), a densidade varia de $0,5 \mathrm{~km} / \mathrm{km}^{2}$, em bacias com o comprimento de rios permitiu constatar que a bacia apresenta uma rede de drenagem de 657,63 km, revelado através dos seus comprimentos totais de $1^{\underline{a}}$ a $5^{\underline{a}}$ ordem. Os canais de primeira ordem correspondem a um total de 402, os de segunda ordem 205, os de terceira ordem 80, os de quarta ordem 53 e os de quinta ordem 60, totalizando um número de 800 canais. 0 canal principal possui uma extensão de 61,54 km distribuídos ao longo de um eixo de $33,70 \mathrm{~km}$, que constitui o comprimento do eixo da bacia e uma declividade de $3,74 \mathrm{~m} / \mathrm{km}$. 0 canal principal apresentou uma declividade média 3,74 m/km. 0 índice de sinuosidade de 1,91 mostra que o canal tende a ser tortuoso.

Figura 9 - Rede de Drenagem da Bacia Hidrográfica do Rio Jacarecica.

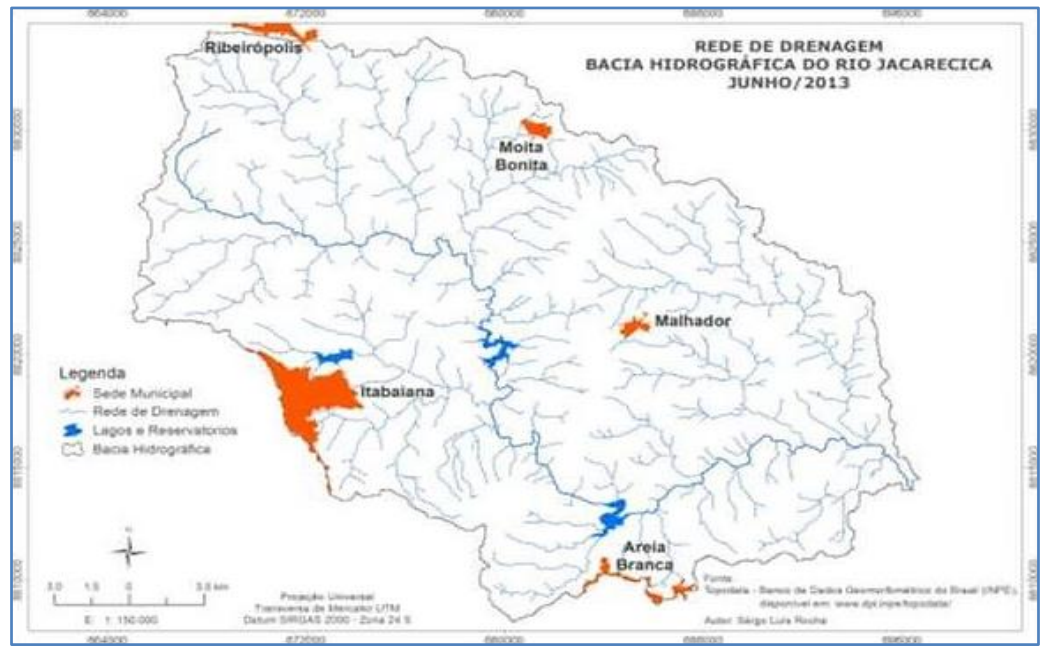

Segue abaixo síntese dos parâmetros obtidos a partir da análise morfométrica da bacia hidrográfica do rio Jacarecica, estado de Sergipe. 
Tabela 1. Parâmetros Básicos Planimétricos da Bacia Hidrográfica do Rio Jacarecica.

\begin{tabular}{|c|c|c|c|}
\hline Parâmetro & Sigla & Fórmula & Valor \\
\hline Área da Bacia & A & ----- & $507,29 \mathrm{~km}^{2}$ \\
\hline Perímetro da Bacia & $\mathrm{P}$ & ---- & $152,61 \mathrm{~km}$ \\
\hline Comprimento do Eixo da Bacia & $\mathrm{C}$ & ----- & $33,70 \mathrm{~km}$ \\
\hline Maior Largura da Bacia & $\mathrm{L}$ & $----\cdot$ & $20,34 \mathrm{~km}$ \\
\hline Comprimento da Rede de Drenagem & $\mathrm{Lt}$ & ----- & $657,63 \mathrm{~km}$ \\
\hline Comprimento dos Canais de $1^{\mathrm{a}}$ Ordem & Lt1 & ---- & $327,62 \mathrm{~km}$ \\
\hline Comprimento dos Canais de $2^{\underline{a}}$ Ordem & Lt2 & ---- & $169,73 \mathrm{~km}$ \\
\hline Comprimento dos Canais de $3 \stackrel{a}{a}$ Ordem & Lt3 & ---- & $71,49 \mathrm{~km}$ \\
\hline Comprimento dos Canais de $4^{\mathrm{a}}$ Ordem & Lt4 & 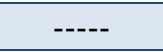 & $39,96 \mathrm{~km}$ \\
\hline Comprimento dos Canais de 5a Ordem & Lt5 & $-\cdots$ & $48,83 \mathrm{~km}$ \\
\hline Ordem da Bacia & $\begin{array}{ll}----- \\
\end{array}$ & ----- & Quinta Ordem \\
\hline Comprimento do Canal Principal & $\mathrm{Cp}$ & ---- & $61,54 \mathrm{~km}$ \\
\hline Comprimento do Canal Principal Rebatido & $\mathrm{Rb}$ & ----- & $32,18 \mathrm{~km}$ \\
\hline Número de Canais da Bacia & $\mathrm{Nt}$ & $-\cdots--$ & 800 \\
\hline Número de Canais de $1^{\mathrm{a}}$ Ordem & Nwn & ----- & 402 \\
\hline Número de Canais de 2 a Ordem & Nwn & ---- & 205 \\
\hline Número de Canais de 3 a Ordem & Nwn & ---- & 80 \\
\hline Número de Canais de 4 a Ordem & Nwn & $----\cdot$ & 53 \\
\hline Número de Canais de 5 a Ordem & Nwn & ---- & 60 \\
\hline
\end{tabular}

Tabela 2. Parâmetros Básicos Altimétricos da Bacia Hidrográfica do Rio Jacarecica.

\begin{tabular}{l|c|c|c}
\hline \multicolumn{1}{c|}{ Parâmetro } & Sigla & Fórmula & Valor \\
\hline Menor Altitude da Bacia & Hmin & ---- & $04 \mathrm{~m}$ \\
\hline Maior Altitude da Bacia & Hmax & ---- & $657 \mathrm{~m}$ \\
\hline Altitude Média da Bacia & Hmed & ---- & $177,40 \mathrm{~m}$ \\
\hline Menor Altitude do Canal Principal & HCmin & ---- & $07 \mathrm{~m}$ \\
\hline Maior Altitude do Canal Principal & HCmax & ---- & $237 \mathrm{~m}$ \\
\hline Declividade Média da Bacia & Dcmed & ---- & $12,29 \%$ \\
\hline
\end{tabular}

Tabela 3. Parâmetros Derivados Morfológicos da Bacia Hidrográfica do Rio Jacarecica.

\begin{tabular}{l|cccc}
\multicolumn{1}{c|}{ Parâmetro } & Sigla & Fórmula & Valor \\
\hline Amplitude Altimétrica da Bacia & $\Delta \mathrm{H}$ & $\Delta \mathrm{H}=\mathrm{Hmax}-\mathrm{Hmin}$ & $653 \mathrm{~m}$ \\
\hline Amplit. Altimétrica do Canal Principal & $\Delta \mathrm{HCp}$ & $\Delta \mathrm{HCp}=\mathrm{HCpmax}-$ & $230 \mathrm{~m}$ \\
\hline Densidade de Drenagem da Bacia & $\mathrm{Dd}$ & $\mathrm{Lt} / \mathrm{A}$ & $1,30 \mathrm{~m} / \mathrm{km}^{2}$ \\
\hline Densidade Hidrográfica da Bacia & $\mathrm{Dh}$ & $\mathrm{Nt} / \mathrm{A}$ & $1,58 \mathrm{~km}^{2}$ \\
\hline Comprmto Médio da Rede de Drenagem & $\mathrm{Lm}$ & $\mathrm{Lt} / \mathrm{Nt}$ & $0,82 \mathrm{~km}$ \\
\hline Extensão do Percurso Superficial & $\mathrm{Eps}$ & $1 / 2 \mathrm{Dd}$ & $0,38 \mathrm{~km}$ \\
\hline Razão de Textura da Bacia & $\mathrm{Kc}$ & $\mathrm{Kc}=0,28 \times \mathrm{P} / \sqrt{\mathrm{A}}$ & $5,24 \mathrm{~km}^{-1}$ \\
\hline Coeficiente de Compacidade da Bacia & $\Delta \mathrm{HCp}$ & $\Delta \mathrm{HCp}=\mathrm{HCpmax}-$ & 1,9 \\
\hline Fator de Forma da Bacia & $\mathrm{F}$ & $\mathrm{F}=\mathrm{A} / \mathrm{L}^{2}$ & 1,23 \\
\hline Índice de Circularidade da Bacia & $\mathrm{IC}$ & $\mathrm{IC}=12,57 \times \mathrm{A} \mathrm{A} / \mathrm{P}^{2}$ & $0,27 \mathrm{~m}$ \\
\hline Razão de Relevo da Bacia & $\mathrm{Rr}$ & $\mathrm{Rr}=\Delta \mathrm{H} / \mathrm{C}$ & 19,38 \\
\hline Razão de Relevo Relativo da Bacia & $\mathrm{Rrl}$ & $\mathrm{Rrl}=\Delta \mathrm{H} / \mathrm{P}$ & 4,28 \\
\hline Coeficiente de Rugosidade da Bacia & $\mathrm{RN}$ & $\mathrm{RN}=\mathrm{Dd} / \mathrm{Decm}$ & $0,11 \mathrm{~m}$ \\
\hline Declividade do Canal Principal & $\mathrm{S}$ & $\mathrm{S}=\Delta \mathrm{HCp} / \mathrm{Cp}$ & $3,74 \mathrm{~m} / \mathrm{km}$ \\
\hline
\end{tabular}


Tabela 4. Parâmetros Derivados Hidrológicos da Bacia Hidrográfica do Rio Jacarecica.

\begin{tabular}{l|c|c|c}
\multicolumn{1}{c|}{ Parâmetro } & Sigla & Fórmula & Valor \\
\hline Coeficiente de Manutenção & $\mathrm{Cm}$ & $\mathrm{Cm}=1 / \mathrm{Dd} \times 1000$ & $769,23 \mathrm{~m}^{2}$ \\
\hline Índice de Sinuosidade & Is & Is $=\mathrm{Cp} / \mathrm{Rb}$ & 1,91 \\
\hline Índice de Sinuosidade & Is & Is $=100(\mathrm{Cp}-\mathrm{Rb}) / \mathrm{Cp}$ & $47,71 \%$ \\
\hline Tempo de Concentração & $\mathrm{Tc}$ & $\mathrm{Tc}=4 \sqrt{\mathrm{A}}+1,5 \mathrm{Cp} / 0,8 \sqrt{\Delta \mathrm{H}}$ & $8,92 \mathrm{~h}$ \\
\hline
\end{tabular}

\section{CONSIDERAÇÕES FINAIS}

Um dos objetivos básicos deste trabalho foi avaliar a utilização da função DEM Reconditioning, a partir do Modelo Digital de Elevação (MDE), projeto TOPODATA, no processo de reprodução da rede de drenagem editada a partir das imagens SPOT 5, através do método de interpretação visual.

Neste sentido, a utilização das ferramentas do ArcHydro incorporadas ao ArcGis permitiram realizar de forma rápida e padronizada o delineamento e a caracterização morfométrica da bacia hidrográfica do rio Jacarecica e da rede de drenagem associada. Esta análise não seria possível se tivéssemos como base tão somente a rede de drenagem originária das imagens SPOT 5.

Vale lembrar que os dados SRTM, na forma em que foram disponibilizados para América do Sul, apresentam resolução horizontal (i.e., resolução espacial) de 3 arco- segundos $(\sim 90 \mathrm{~m})$ e resolução vertical de $1 \mathrm{~m}$. Assim a metodologia utilizada a partir dos dados TOPODATA (Banco de Dados Geomorfométricos do Brasil), aplica-se às escalas entre 1:100.000 e 1:250.000.

\section{REFERÊNCIAS}

[1] ALCÂNTARA E. H. \& AMORIM, A. J. Análise morfométrica de uma Bacia Hidrográfica Costeira: Um Estudo de Caso. Caminhos de Geografia 7(14) 70-77, fev 2005. Disponível em: www.seer.ufu.br/index.php/caminhosdegeografia/article/.../867. Acesso em: 23 de abr de 2013.

[2] ALMEIDA. F. F. M. 0 Cráton do São Francisco. Revista Brasileira de Geociências, São Paulo, v.7, no 4, p.349 364, dez. 1977.

[3] ALVES, J. M. P.; CASTRO, P. T. A. Influência de feições geológicas na morfologia da bacia do rio Tanque (MG) baseada no estudo de parâmetros morfométricos e análise de padrões de lineamentos. Revista Brasileira de Geociências, São Paulo, v. 33, n. 2, p.117- 127, 2003. Disponível em: sbgeo.org.br/pub_sbg/rbg/vol33_down/3302/1239.pdf. Acesso em: 05 de maio de 2013.

[4] BRASIL. Instituto Brasileiro de Geografia e Estatistica (IBGE). Manual técnico de geomorfologia, Coordenação de Recursos Naturais e Estudos Ambientais. - 2. ed. - Rio de Janeiro: IBGE, 2009. Disponível em: ftp://geoftp.ibge.gov.br/.../manuais_tecnicos/manual_tecnico_geomorfologia. Acesso em 20 de mar de2013.

[5] . Agência Nacional de Água (ANA). Manual ARC-HYDRO para aplicaçãodomodeloMGB-IPH. Versão 1.2, Projeto Integrado de Cooperação Amazônica e de Modernização do Monitoramento Hidrológico, Brasília, 2009. Disponível em pt.scribd.com/doc/39682348/Manual-ArcHydro-1-:Acesso em 10 de abr de2013.

[6] . Empresa Brasileira de Pesquisa Agropecuária (EMBRAPA). Sistemabrasileirodeclassificação de solos, Centro Nacional de Pesquisa de Solos. - 2. ed. - Rio de Janeiro: EMBRAPA-SPI, 306P.2006. Disponível em: www.solos.ufmt.br/docs/solos3/SIBCs_2009.pdf. Acesso em 20 mar de2013.

[7] .ServiçoGeológicodoBrasil(CPRM).GeologiadoEstadodeSergipe.Brasília:CPRM/DIEDIG/DEPAT; CODISE. 2001. Disponível em: www.cprm.gov.br/arquivos/pdf/sergipe/sergipe_geologia.pdf. Acesso em 20 de mar de 2013.

[8] CÂMARA, Gilberto; DAVIS, Clodoveu; MONTEIRO, Antonio M.V. Introdução à Ciência da Geoinformação. Capítulos 1 e 2 . Instituto Nacional de Pesquisas Espaciais - INPE. <http://www.dpi.inpe.br/gilberto/livro/introd/index.html> Acesso em: 23 de abr 2013.

[9] CARDOSO, C. A.; DIAS, H. C. T.; SOARES, C. P.; MARTINS, S. V. Caracterização

[10] Morfométrica da Bacia Hidrográfica do Rio Debossan. Revista Árvore, Nova Friburgo-RJ, 2006, v. 30, p. 241-248.

[11] CHRISTOFOLETTI, A. Análise Morfométrica das Bacias Hidrográficas. Notícia Geomorfológica, Campinas, v.9, pp. 35-64, 1969. 
[12] DA SILVA, Andressa C. C., MARIANE, Leidiane, GONZÁLES, Rafael H. de Aguiar. Manual do Curso de Gestão Territorial para Recursos Hídricos com Solfware livre para Código Aberto. Foz do Iguaçu,2012.

[13] ESRI - Environmental Systems Research Institute. Inc. ArcGis Professional GIS for the desktop, version 10.0, software. 2009.

[14] FILZIKOWSKI, L. M.; PELEGRINO, E. A .F.; MAIS, A. G. Análise comparativa entre equações de tempo de concentração na bacia hidrográfica do arroio dos Pereiras, VI Semana de Estudos de Engenharia Ambiental, Irati, PR,2008.

[15] FREITAS, P.L. de; KER, J. C. As pesquisas em microbacias hidrográficas: situação atual, entraves e perspectivas no Brasil. In: CONGRESSO BRASILEIRO E ENCONTRO NACIONAL DE PESQUISA SOBRE CONSERVAÇÃO DO SOLO, 8., 1990, Londrina.Anais...Londrina:

[16] Instituto Agronômico do Paraná, 1996. p. 43-57. Disponível em asterope.recad.usp.br/prod/unid/fcf/cpdan/CV156.html. Acesso em 13 mar de 2013.

[17] HORTON, R.E. Drainage Basin Analysis. Trans. American Geophysical Union, v. 13, 1932. 105-116. Disponível em: www.wou.edu/las/physci/.../drainage_anal.pdf. Acesso em 13 mar de2013.

[18] LINDNER, E. A.; GOMIG, K \& KOBIYAMA, M. Sensoriamento remoto aplicado à caracterização morfométrica e classificação do uso do solo na bacia rio do Peixe/SC. Anais XIII Simpósio Brasileiro de Sensoriamento Remoto, Florianópolis, Brasil, 21-26 abril 2007, INPE, P.3405-3412. Disponível em: tede.unioeste.br/tede/tde_busca/processaArquivo.php?codArquivo=403. Acesso em 13 de mar de2013.

[19] PORTO, Mônica F. A; PORTO, Rubem La Laina (2008) “Gestão de Bacias Hidrográficas”, Estud. av. Vol.22 no.63, São Paulo, 2008.

[20] RAMALHO, F. A. BEEK, K. J. Sistema de Avaliação da Aptidão Agrícola das Terras.3. ed.

[21] ROCHA, J. S. M. KURTZ, S. M. J. M. Manual de Manejo Integrado de Bacias Hidrográficas. Santa Maria: Editora da UFSM, 2001. 282p.

[22] SCHUMM, S. A. Evolution of drainage systems and sloes in bed-lands at Perth Amboy, New Jersey. Bulletin of Geological Society of America, Colorado, v. 67, p.597-646, 1956.

[23] SERGIPE. Atlas Digital sobre Recursos Hídricos do Estado de Sergipe. Aracaju: Secretaria de Meio Ambiente e Recursos Hídricos/Superintendência de Recursos Hídricos - SEMARH/SRH, 2013. (CD ROOM).

[24] .Plano Estadual de Recursos Hídricos de Sergipe. Aracaju: Secretaria de Meio Ambiente e Recursos Hídricos/Superintendência de Recursos Hídricos - SEMARH/SRH, 2012. (CDROOM).

[25] SILVA, A. M.; MELO, C. R.; Bacia hidrográfica: teoria. Lavras, UFLA,.2006. Disponível em<http://www.deg.ufla.br/irrigação/Disciplinas/ENG\%20170/hidrologia_eng_170.htm Acesso em 14 maio de 2013.

[26] STRAHLER, A. N. Quantitative analysis of watershed geomorphology. American Geophysical Union Transactions. v. 38, p.913-920. 1957.

[27] TONELLO, K.C. Análise hidroambiental da bacia hidrográfica da cachoeira das Pombas, Guanhães, MG. 2005. 69p. Tese (Doutorado em Ciências Florestais) - Universidade Federal de Viçosa, Viçosa, 2005. Disponível em: www.uniara.com.br/revistauniara/pdf/20/RevUniara20_11.pdf. Acesso em 28 de maio de2013.

[28] VALERIANO, M. M. Topodata: Guia para utilização de dados geomorfológicos locais. São José dos Campos, SP: INPE: Do projeto de Produtividade em pesquisa "Modelagem de dados topográficos SRTM", CNPq, processo noㅡ 306021/2004-8 (NV). (INPE-15318- RPQ/818). 72p. 2008.

[29] VAlERIANO, M. M.; AlBuQuerquE, P. C. G. Topodata: Processamento dos dados SRTM. São José dos Campos, SP: INPE: Do projeto de Produtividade em Pesquisa "Desenvolvimento de aplicações de dados topográficos SRTM", CNPq, processo n॰307530/2008-6(NV). (INPE-16702-RPQ/854). 77p. 2010.

[30] VILlELA, S. M.; MATTOS, A. Hidrologia Aplicada. São Paulo, Ed. McGraw Hill do Brasil, 1975, 245p. 


\title{
CAPÍTULO \\ Classificação climática da bacia hidrografica do rio Jacarecica
} 02

\author{
Ruberval Leone Azevedo \\ Inajá Francisco de Sousa
}

\section{INTRODUCCÃO}

O estudo da Climatologia de um determinado local ou região tem importância, pois o clima é fator preponderante que exerce influência nas atividades humanas, consequentemente na gestão dos Recursos Hídricos. Devemos fazer aqui uma distinção entre Clima e Tempo: 0 Clima é o conjunto das condições atmosféricas que ocorrem em determinado local por um período muito longo, e que torna característico dele. Já o Tempo refere-se ao estado momentâneo das condições climáticas de determinado local, como, por exemplo, hoje está chovendo, está frio etc.

Climatologia é um dos ramos da Geografia Física que estuda o tempo e o clima.E este estudo da climatologia tem fundamental importância, pois o clima influencia diretamente as plantas, os animais e no homemetc, a climatologia aborda os padrões de comportamento da atmosfera em suas interações com as atividades humanas. 0 clima de uma região é fator preponderante de influência na sociedade em atividades como: a agricultura, a produção de energia, o abastecimento de água, entre outras. (BARROS \& ZAVATTINI, 2009; CUPOLILLO\&VIANELLO, 2008; MENDONÇA \& DANNI-OLIVEIRA, 2007;).

Segundo Pinto e Netto (2008, p.12) “O clima não é um fato, mas uma teoria, uma abstração, da qual tira proveito cada investigador para implementar uma dada experiência de tempo (meteorológico) adequada a seus propósitos. Alguns autores recorrem à estratégia quantitativa considerando o clima como estado médio dos elementos atmosféricos sobre dado lugar. Outros preferem escapar da quantificação recorrendo a uma descrição qualitativa, tentando expressar o comportamento genético da dinâmica atmosférica sobre dado lugar ou espaço. Entretanto todos pressupõem uma sucessão de tipos de tempo".0 conhecimento do clima é fundamental para o planejamento da gestão dos recursos hídricos. O impacto do clima sobre os recursos hídricos é um fato de grande relevância social e ambiental. Em situação extrema pode comprometer a sustentabilidade da sociedade e da conservação ambiental (TUCCI \& BRAGA, 2003). Informações relativas ao clima - as informações climatológicas (precipitação, evaporação, evapotranspiração, temperatura, e outras) exigem grande número de

observações, quer no espaço quer no tempo, a fim de se poder caracterizar de forma adequada a sua probabilidade de ocorrência ( SETTI et. al., 2001).

Existem várias classificações climáticas, propostas por vários pesquisadores, que possuem cada uma suas peculiaridades,seus méritos próprios, limitações e falhas. Essas são classificadas por alguns autores como empíricas que consiste na observação dos elementos climáticos meteorológicos, como temperatura e precipitação, que são os mais comumente utilizados,ou genéticasque utiliza os fatores que determinam o clima enfatizando especialmente a circulação atmosférica(NÓBREGA, 2010; MENDONÇA \&DANNI-OLIVEIRA, 2007; JURCA, 2005; AYOADE, 1996).

Uma dessas classificações, aproposta porThornthwaite\&Mather (1955) que é muito usada na agricultura, foi desenvolvida para determinar o regime hídrico de um local, sem necessidade de medidas diretas das condições do solo.Utiliza-se uma escala de índices climáticos definidos com base no balanço hídrico climatológico (BHC) - índice hídrico, índice de aridez e índice de umidade, constituindo uma das metodologias mais clássicas de regionalização climática(PEREIRA, 2005 ; PEREIRA et. al., 2002),.

o Nordeste Brasileiro apresenta uma variabilidade interanual bastante intensa, particularmente no que diz respeito à precipitação, e à disponibilidade dos recursos hídricos, com apresentando alguns anos extremamente secos e outros anos extremamente chuvosos. Essa é uma região da América do sul onde os sinais da desta variabilidade intrassazonal são mais evidentes, devido à irregularidade das chuvas e os índices pluviométricos, que normalmente são abaixo de $600-800 \mathrm{~mm}$ por ano(CAVALCANTI et. al., 2009 : MARENGO et. al.,2011). 
Entre os principais fatores que determinam a variabilidade sazonal do clima na região Nordeste está: a posição geográfica, o relevo, as características da superfície e os sistemasde tempo atuantes na região (CAVALCANTIet. al., 2009, MARENGO, et al., 2011).

Esses fatores climáticos que produzem o regime de precipitações do Nordeste são excessivamente complexos e estão ligados à influência e à conjugação de vários sistemas de circulação atmosférica, agindo separadamente nas diferentes partes desta Região. A esses mecanismos, que são muito dependentesdiretamente da circulação atmosférica geral, superpõe-se diversos outros fatores citados por vários autores, como a orografia ou aproximidade e temperatura do mar;a Zona de Convergência Intertropical (ZCIT) ; Frentes Frias, Vórtices Ciclônicos de Altos Níveis (VCAN) ; atuação das linhas de Instabilidade (LI), dos Complexos Convectivos de Mesoescala (CCM) ; o El Niño que altera o clima regional e global, mudando os padrões de vento afetando, os regimes de chuva em regiões tropicais e de latitudes médias. Calcula-seque ocorrem de 18 a 20 os de seca no Nordeste a cada intervalo de100 anos, toma-se como exemplo a "Grande Seca" de 1877-1878 que ocasionou a morte de cerca de 500 mil pessoas.(MOLINIER, et al., 1994; MARENGO et al., 2011; FERREIRA \& MELLO, 2005).

Segundo Carvalho e Fontes, (2006), o Estado de Sergipe está sob a influênciadas oscilações da Zona de Convergência Intertropical (ZCIT), que é uma banda de nuvens que circunda a faixa equatorial do globo terrestre, um dos sistemas atmosféricosmais importantes atuando nos trópicos; da Massa de arTropical Atlântica (mTa), que é uma massa de ar quente e úmida atuante no verão e a Massa Equatorial Atlântica (mEa) e de sistemasfrontológicos que se individualizam na Frente Polar Atlântica (FPA)e nas Correntes Perturbadas de Leste (Ondas de Leste) que sãodecisivas na manutenção de um regime pluviométrico caracterizadopor chuvas mais abundantes no período outono/inverno. Os ventos alísios oriundos do centro de alta pressão doAtlântico Sul atuam durante todo o ano, variando de SE para NE, adepender do próprio deslocamento do Anticiclone, também é atuante o Vórtice Ciclônico em Ar Superior (VCAS) (FERREIRA \& MELLO, 2005; COSTA et. al, 2004).

Segundo Costa et. al, (2004), o regime pluviométrico do Estado de Sergipe está associado às condições atmosféricas esistemas sinóticos que atuam nos setores Norte e Leste do Nordeste do Brasil e possui uma característica própria diferente dos demais regimes da região do $\mathrm{NEB}$, apresentando uma grande variabilidade interanual (com desvio da média climatológica superior a um desvio padrão). Devido à sua posição geográfica espacial, Sergipe possui uma característica de transição entre osregimes pluviométricos do norte (com máximos de fevereiro a maio) e do sul do NEB (dezembro afevereiro). Essa transição é observada no início da estação chuvosa alterando a precipitação ecausando veranicos. Os mesmos autores mencionam ainda que o máximo pluviométrico ocorre em maio, entretanto quando há um deslocamento anômalo da Zona de Convergência Intertropical (ZCIT), mais para o norte, duranteo regime pluviométrico do norte do NEB, o início da estação chuvosa do Leste do NEB é afetado consideravelmente, chegando a haver "veranicos".

Dentro desse contexto, o presente trabalho tem como objetivo de caracterizar os tipos climáticos da Bacia Hidrográfica do Rio Jacarecica-SE.

\section{METODOLOGIA}

\subsection{A BACIA HIDROGRÁFICA DO RIO JACARECICA}

A bacia hidrográfica do Rio Jacarecica está localizada na região agreste central do Estado de Sergipe. Possui uma área de aproximadamente $501,99 \mathrm{~km} 2$, com sete municípios com áreas totais ou parcialmente inclusas no território da bacia, que são: Itabaiana, Areia Branca, Riachuelo, Santa Rosa de Lima, Moita Bonita, Ribeiropólis e Malhador como único município tendo seu território totalmente inserido na bacia. Seu território é dividido entre o Agreste e Litoral Úmido, o Rio Jacarecica é um dos principais afluentes do Rio Sergipe (MELO NETO et al., 2010, SEMARH, 2013).

Para o desenvolvimento do presente trabalho utilizou-se a sériede dados pluviométricos (Séries históricas mensais disponíveis) dos 06 seis municípios que compõe a Bacia Hidrográfica do Jacarecica (Tabela 1), com exceção do município de Areia Branca que não foram encontrados dados pluviométricos, estes dados de precipitação foram obtidos junto ao Centro de Meteorologia de Sergipe CEMESE/SRH/SEMARH. Também foramfeitas consultasde dados nos sites:ANA- Hidroweb, e no Sistema Nacional de Informações sobre Recursos Hídricos - SNIRH, da Agência Nacional das Águas - ANA, disponíveis na internet (SNIRH, 2013). 
Tabela 1- Estações Meteorológicas e Postos Pluviométricos encontrados na Bacia Hidrográfica do Rio Jacarecica/SE.

\begin{tabular}{|c|c|c|c|c|c|c|c|c|c|}
\hline Município & $\begin{array}{l}\text { Nome da } \\
\text { estação ou } \\
\text { posto }\end{array}$ & Responsável & Operadora & $\begin{array}{l}\text { Código } \\
\text { ANA }\end{array}$ & Latitude & Longitude & $\begin{array}{l}\text { Altitude } \\
\text { (m) }\end{array}$ & $\begin{array}{c}\text { Período de } \\
\text { Dados }\end{array}$ & Situação \\
\hline Itabaiana & Itabaiana 1 & SEMARH & SEMARH & - & $10^{\circ} 41^{\prime} 59$ & $37^{\circ} 25^{\prime} 12$ & 200 & 2008-atual & $\begin{array}{c}\text { Em } \\
\text { operação }\end{array}$ \\
\hline Itabaiana & Açude Itabaiana & DNOCS & DNOCS & 1037019 & $-10^{\circ} 40^{\prime} 59.88$ & $37^{\circ} 25^{\prime} 00.12$ & 186 & $1913-1985$ & Desativada \\
\hline Itabaiana & $\begin{array}{c}\text { Perímetro } \\
\text { irrigado do } \\
\text { Jacarecica i } 1\end{array}$ & COHIDRO & COHIDRO & - & $-10^{\circ} 7^{\prime}$ & $37{ }^{\circ} 3^{\prime}$ & 161 & 1987-atual & $\begin{array}{c}\text { Em } \\
\text { operação }\end{array}$ \\
\hline Itabaiana & Fase 2 & FASE & FASE & 1037058 & $-10^{\circ} 40^{\prime} 59.99$ & $-37^{\circ}-25^{\prime} 01.20$ & 188 & $1956-1959$ & Desativada \\
\hline Itabaiana & Itabaiana 2 & EMDAGRO & EMDAGRO & - & $-10^{\circ} 40^{\prime}$ & $-37^{\circ} 25^{\prime}$ & - & - & $\begin{array}{c}\text { Em } \\
\text { operação }\end{array}$ \\
\hline Malhador & Malhador 2 & SUDENE & SUDENE & 1037030 & $-10^{\circ} 40^{\prime} 00.12$ & $-37^{\circ}-18^{\prime} 00.00$ & 224 & $1963-1984$ & Desativada \\
\hline Riachuelo & Riachuelo 2 & SUDENE & SUDENE & 1037042 & $-10^{\circ}-43^{\prime} 59.88$ & $-37 \div 10^{\prime} 59.88$ & 30 & 1963-1999 & Desativada \\
\hline Ribeirópolis & Ribeirópolis 2 & DNOS & DNOS & 1037044 & $-10^{\circ} 31^{\prime} 59.88$ & $-37^{\circ} 25^{\prime} 59.88$ & 350 & 1940-1999 & Desativada \\
\hline $\begin{array}{c}\text { Santa Rosa de } \\
\text { Lima } \\
\end{array}$ & Camboata 2 & ANA & CPRM & 1037049 & $-10^{\circ} 39^{\prime} 10.08$ & $-37^{\circ}-11^{\prime} 34.08$ & 47 & 1952-atual & $\begin{array}{c}\text { Em } \\
\text { operação }\end{array}$ \\
\hline Malhador & Malhador 2 & EMDAGRO & EMDAGRO & - & $10^{\circ} 39^{\prime} 33$ & $37^{\circ} 18^{\prime} 12$ & 100 & - & $\begin{array}{c}\text { Em } \\
\text { operação }\end{array}$ \\
\hline Moita bonita & Moita bonita 2 & EMDAGRO & EMDAGRO & - & $10^{\circ} 34^{\prime} 40^{\prime \prime}$ & $37^{\circ} 20^{\prime} 37^{\prime \prime}$ & 180 & - & $\begin{array}{c}\text { Em } \\
\text { operação }\end{array}$ \\
\hline Ribeirópolis & Ribeirópolis 2 & EMDAGRO & EMDAGRO & - & $10^{\circ} 32$ '26" & $37^{\circ} 26^{\prime} 05^{\prime \prime}$ & 250 & - & $\begin{array}{c}\text { Em } \\
\text { operação }\end{array}$ \\
\hline
\end{tabular}

1- Estação Meteorológica. 2 - Posto Pluviométrico

Existe uma carência de estações meteorológicas no perímetro da bacia e consequentemente de dados meteorológicos, a maioria das estações pertence à ANA que dispõem somente de dados de chuva coletados através de pluviômetros Ville de Paris, com área de captação de $400 \mathrm{~cm} 2$, que faz parte da Rede Hidrométrica Básica do Nordeste operada pela Superintendência do Desenvolvimento do Nordeste - SUDENE. Dessas apenas uma está ativa que é a estação de Santa Rosa de Lima/Camboatá. Á exceção ás estações da ANA é a Plataforma de Coletas de Dados (PCD) em Itabaiana da SRH/SEMARH, Estação Pluviométrica do Perímetro Irrigado de Jacarecica I da Companhia de Desenvolvimento de Recursos Hídricos e Irrigação de Sergipe - COHIDRO, e alguns pluviômetros instalados pela EMDAGRO - Empresa de Desenvolvimento Agropecuário de Sergipe em Malhador, Moita Bonita e Ribeirópolis e Itabaiana (Figura 1).

Figura1 - Estações Meteorológicas e Postos Pluviométricos localizados na Bacia Hidrográfica do Rio Jacarecica/SE.

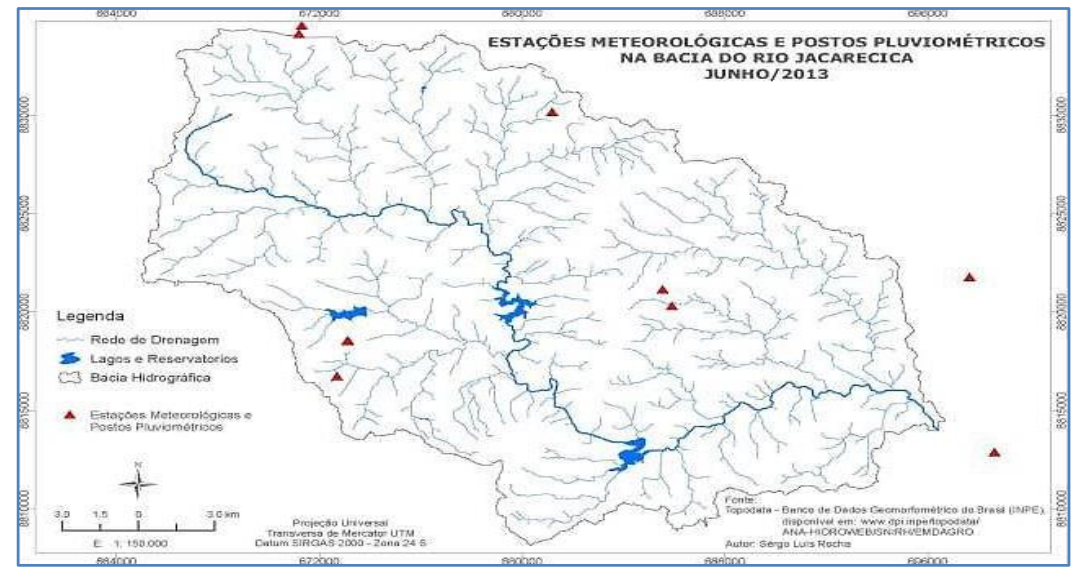


Os dados de temperatura do ar dos 06 seis municípios da Bacia foram estimados, pois não há dados disponíveis, e foram através do Software Estima-T, disponívelno site da internet da Unidade Acadêmica de Ciências Atmosféricas, da Universidade Federal de Campina Grande-UFCG. O Estima_T é um software para fazer estimativas de temperaturas do ar na Região Nordeste do Brasil quando da ausência desses, em função da latitude, longitude e altitude da localidade em estudo (CAVALCANTI et al., 2006).

A confecção do balanço hídrico climático de Thornthwaite e Mather (1955), foi feito com o auxílio de planilha EXCEL através do programa "BHnorm" elaborado por Rolim et.al. (1998), com a capacidade de água disponível (CAD) de $100 \mathrm{~mm}$, para estudos climáticos, sem a associação de uma cultura agrícola específica, normalmente adota-se valores de CAD variando de 75 a $125 \mathrm{~mm}$ para o armazenamento de água no solo (PEREIRA et. al., 2007). Para cada município foi gerado um balanço hídrico com os dados de chuva e temperatura conseguidas, obtendo-se assim valores normais das variáveis: Armazenamento (CAD),Armazenamento (ARM) mensal, Extrato do Balanço Hídrico Mensal.

A partir destes dados do balanço hídrico climático foi calculado o índice hídrico (IH) (1) que é a relação em percentagem entre o excedente hídrico (EXC) e a evapotranspiração potencial (ETP) ;o índice de umidade (IU) (2) que é o excesso hídrico da evapotranspiração potencial anual e o índice de aridez (IA) (3) que expressa a deficiência hídrica em percentagem da evapotranspiração potencial, pelas seguintes expressões:

- $\quad \mathrm{IH}=(100 \mathrm{EXC}-\mathrm{DEF}) / \mathrm{EP}$

- $\mathrm{IU}=(100 \mathrm{EXC}) / \mathrm{EP}$

- $\mathrm{IA}=(100 \mathrm{DEF}) / \mathrm{EP}$

A classificação climática dos municípios da Bacia foi elaborada a partir do método proposto por Thornthwaite e Mather (1955) (PEREIRA et. al., 2002). A classificaçãoleva em conta quatro letras ou subdivisão climáticas: A primeira se refere ao índice de umidade, a segunda indica os traços dominantes da variação sazonal de umidade efetiva, terceira aponta a eficiência térmica e a quarta representa a concentração da eficiência térmica no verão em função da evapotranspiração potencial (Tabelas 2, 3, 4 e 5).

Os (4) tipos ou subdivisões climáticas, segundo a metodologia de Tornthwaite \& Mather (1955).

Tabela 2 - Subdivisões de Tipos Climáticos (1955), baseado no índice no índice de umidade

\begin{tabular}{|c|c|c|}
\hline Tipos Climáticos & Vegetação Associada & Índice de Umidade (Im) \\
\hline A -Superúmido & Floresta úmida & $100 \leq \operatorname{Im}$ \\
\hline $\mathrm{B}_{4}$ - Úmido & Floresta & $80 \leq \operatorname{Im}<100$ \\
\hline $\mathrm{B}_{3}$ - Úmido & Floresta & $60 \leq \operatorname{Im}<80$ \\
\hline $\mathrm{B}_{2}$ - Úmido & Floresta & $40 \leq \operatorname{Im}<60$ \\
\hline $\mathrm{B}_{1}$ - Úmido & Floresta & $20 \leq \operatorname{Im}<40$ \\
\hline $\mathrm{C}_{2}$ - Subúmido & Campos & $0 \leq \operatorname{Im}<20$ \\
\hline $\mathrm{C}_{1}$ - Subúmido seco & Campos & $-33,3 \leq \operatorname{Im}<0$ \\
\hline D - Semiárido & Estepes & $-66,7 \leq \operatorname{Im}<-33,3$ \\
\hline E - Árido & Desertos & $-100 \leq \operatorname{Im}<66,7$ \\
\hline
\end{tabular}


Tabela 3 - Subdivisões de Tipos Climáticos baseado índice de aridez

\begin{tabular}{l|l|c}
\hline \multirow{2}{*}{ Tipos Climáticos } & \multicolumn{1}{|c}{ Vegetação Associada } & Índice de aridez \\
\hline \multirow{4}{*}{ Úmido A, B, C2 } & r - déficit de água pequena ou nula & $0,0 \leq \mathrm{Ia}<16,7$ \\
\cline { 2 - 3 } & s - déficit de água moderada no verão & $16,7 \leq \mathrm{Ia}<33,3$ \\
\cline { 2 - 3 } & w - déficit de água moderada no inverno & $16,7 \leq \mathrm{Ia}<33,3$ \\
\cline { 2 - 3 } & s2 - grande deficiên cia de água no verão & $33,3 \leq \mathrm{Ia}$ \\
\cline { 2 - 3 } & w2 - grande deficiência de água no inverno & $33,3 \leq \mathrm{Ia}$ \\
\hline \multirow{5}{*}{ Seco C1, D, E } & d - excesso de água pequena ou nula & $0,0 \leq \mathrm{Ih}<10,0$ \\
\cline { 2 - 3 } & s - excesso de água moderada no verão & $10,0 \leq \mathrm{Ih}<20,0$ \\
\cline { 2 - 3 } & w - excesso de água moderada no inverno & $10,0 \leq \mathrm{Ih}<20,0$ \\
\cline { 2 - 3 } & s2 - grande excesso de água no verão & $20,0 \leq \mathrm{Ih}$ \\
\cline { 2 - 3 } & w2 - grande excesso de água no inverno & $20,0 \leq \mathrm{Ih}$ \\
\hline
\end{tabular}

Tabela 4 - Subdivisões de Tipos Climáticos baseado noíndice evapotranspiração potencial

\begin{tabular}{l|c|c}
\multicolumn{1}{c|}{ Tipos Climáticos } & Vegetação Associada & ETP anual $(\mathrm{mm})$ \\
\hline $\mathrm{A}^{\prime}-$ Megatérmico & Floresta tropical úmida & $1140 \leq \mathrm{ETP}$ \\
\hline $\mathrm{B}^{\prime}{ }_{4}-$ Mesotérmico & Floresta temperada úmida & $997 \leq \mathrm{ETP}<1140$ \\
\hline $\mathrm{B}^{\prime}{ }_{3}-$ Mesotérmico & Floresta temperada úmida & $855 \leq \mathrm{ETP}<997$ \\
\hline $\mathrm{B}^{\prime}{ }_{2}-$ Mesotérmico & Floresta temperada úmida & $712 \leq \mathrm{ETP}<855$ \\
\hline $\mathrm{B}_{1}{ }_{1}-$ Mesotérmico & Floresta temperada úmida & $570 \leq \mathrm{ETP}<712$ \\
\hline $\mathrm{C}_{2}-$ Microtérmico & Floresta microtérmica úmida & $427 \leq \mathrm{ETP}<570$ \\
\hline $\mathrm{C}^{\prime}{ }_{1}-$ Microtérmico & Floresta microtérmica úmida & $285 \leq \mathrm{ETP}<427$ \\
\hline $\mathrm{D}^{\prime}-$ Tundra & Tundra & $142 \leq \mathrm{ETP}<285$ \\
\hline E' - Gelo Perpétuo & Não há vegetação & ETP $<142$ \\
\hline
\end{tabular}

Tabela 5 - Subdivisões de Tipos Climáticos baseado na evapotranspiração potencial no verão ETV

\begin{tabular}{l|c}
\multicolumn{1}{c|}{ Tipos Climáticos } & ETV/ ETP anual $(\mathrm{mm})$ \\
\hline a' & ETV $/ \mathrm{ETP}<48,0$ \\
\hline b'4 & $48,0 \leq \mathrm{ETV} / \mathrm{ETP}<51,9$ \\
\hline $\mathrm{b}^{\prime} 3$ & $51,9 \leq \mathrm{ETV} / \mathrm{ETP}<56,3$ \\
\hline b'2 & $56,3 \leq \mathrm{ETV} / \mathrm{ETP}<61,6$ \\
\hline b'1 & $61,6 \leq \mathrm{ETV} / \mathrm{ETP}<68,0$ \\
\hline c'2 $^{\prime}$ & $68,0 \leq \mathrm{ETV} / \mathrm{ETP}<76,3$ \\
\hline c'1 $^{\prime}$ & $76,3 \leq \mathrm{ETV} / \mathrm{ETP}<88,0$ \\
\hline $\mathrm{d}^{\prime}$ & $88,0<\mathrm{ETV} / \mathrm{ETP}$ \\
\hline
\end{tabular}

\section{MAPAS DE ISOIETAS}

0 mapa de isoietas para a bacia hidrográfica do rio Jacarecica (Figura 2) foi definido, compreendendo o período de 1913 a 2012, a partir de seis estações pluviométricas da Agência Nacional das Águas ANA,em uma área de 501,99 $\mathrm{Km}^{2}$.

O programa utilizado para definição das isolinhas de igual precipitação foi o ArcGis ® 10.0(ESRI, 2013), e o método utilizado para interpolação dos pontos das precipitações médias foi a Krigagem Ordinária, que é um método geoestatístico que supõe que a variação espacial de um fenômeno é estatisticamente homogênea em uma determinada área . 
Foi feito um modelo semivariograma esférico,que é um método normalmente utilizado para interpolação e estimação de dados que são demonstrados num gráfico de dispersão da semivariância versus distância dos pontos amostrados (MARCUZZO et al., 2011). As isolinhas foram geradas de 100 em $100 \mathrm{~mm}$ e variaram de 843,06 a 1406,52 mm.

\section{RESULTADOS E DISCUSSÃO}

A Classificação climática dos municípios da Bacia do Jacarecica, elaborada a partir do Balanço Hídrico Climatológico segundo a metodologia de Tornthwaite \& Mather (1955) está descrita na (Tabela 3).

Foram identificados três tipos climáticos: Clima semiárido (D1), Clima subúmido seco (C1), Clima subúmido (C2), houve uma predominância do tipo climático subúmido seco (C1), prevalecendo na maioria dos municípios, com exceção de Itabaiana que foi classificado como clima Semiárido. Estes municípios apresentaram características de excesso hídrico no inverno, ou déficit de água no verão,todos foram classificados dentro do clima megatérmico, e a evapotranspiração potencial média anual variando de 1.158 à 1.436 mm e com relação à concentração da evapotranspiração potencial estimada no verão, ficou em média de 30,67\% nos três (03) meses consecutivos com temperatura mais elevada (Tabela 3).

Tabela 3 -Classificação climática dos municípios da Bacia Hidrográfica do Jacarecica (SE) a partir do Balanço Hídrico Climatológico segundo a metodologia de Tornthwaite\&Mather(1955).

\begin{tabular}{|c|c|c|}
\hline Municipio & Tipo Climático & Descrição do Clima \\
\hline Itabaiana & D1w2A'a' & $\begin{array}{l}\text { Clima semiárido, com excesso hídrico no inverno, megatérmico, evapotranspiração } \\
\text { potencial média anual de } 1.292,12 \mathrm{~mm} \text { e concentração da evapotranspiração potencia } \\
\text { no verão em torno de } 31 \% \text { (três meses consecutivos com temperatura mais elevada). }\end{array}$ \\
\hline Malhador & C2sA'a' & $\begin{array}{c}\text { Clima subúmido, com déficite de água moderado no verão, megatérmico, } \\
\text { evapotranspiração potencial média anual de } 1.248,03 \mathrm{~mm} \text { e concentração da } \\
\text { evapotranspiração potencial no verão em torno de } 31 \% \text { (três meses consecutivos con } \\
\text { temperatura mais elevada). }\end{array}$ \\
\hline Moita Bonita & C1w2A'a' & $\begin{array}{c}\text { Clima subúmido seco, com excesso hídrico no inverno, megatérmico, } \\
\text { evapotranspiração potencial média anual de } 1.336,45 \mathrm{~mm} \text { e concentração da } \\
\text { evapotranspiração potencial no verão em torno de } 31 \% \text { (três meses consecutivos con } \\
\text { temperatura mais elevada). }\end{array}$ \\
\hline Riachuelo & C2sA'a' & $\begin{array}{l}\text { Clima subúmido, com déficit de água no verão, megatérmico, evapotranspiração } \\
\text { potencial média anual de } 1.448,45 \mathrm{~mm} \text { e concentração da evapotranspiração potencia } \\
\text { no verão em torno de } 30 \% \text { (três meses consecutivos com temperatura mais elevada). }\end{array}$ \\
\hline Ribeirópolis & C1w2A'a' & $\begin{array}{c}\text { Clima subúmido seco, com excesso hídrico no inverno, megatérmico, } \\
\text { evapotranspiração potencial média anual de } 1.158,25 \mathrm{~mm} \text { e concentração da } \\
\text { evapotranspiração potencial no verão em torno de } 31 \% \text { (três meses consecutivos con } \\
\text { temperatura mais elevada). }\end{array}$ \\
\hline Santa Rosa de Lima & C1w2A'a' & $\begin{array}{c}\text { Clima subúmido seco, com excesso hídrico no inverno, megatérmico, } \\
\text { evapotranspiração potencial média anual de } 1.436,65 \mathrm{~mm} \text { e concentração da } \\
\text { evapotranspiração potencial no verão em torno de } 30 \% \text { (três meses consecutivos com } \\
\text { temperatura mais elevada). }\end{array}$ \\
\hline
\end{tabular}

As médias térmicas do período (1950-2012) na Bacia ficaram em torno de 24,4ํㅡ C, com máximas de 29,9 C e mínimas de 19,9C,com uma amplitude térmica em torno de10,0ํ․ As maiores precipitações são observadas entre maio e agosto, as menores precipitações ocorrem de setembro a janeiro a. As maiores temperaturas ocorrem de setembro a janeiro, as menores temperaturas se dão entre maio e agosto, como é de se esperar que nos meses de maior precipitação também.

As maiores precipitações ocorrem entres os meses de abril à agosto, Junho é o mês mais chuvoso com precipitações de $198 \mathrm{~mm}$ em média e janeiro e dezembro sendo os meses mais secos com um défice de $90 \mathrm{~mm}$ em média, A precipitação média da bacia fica em torno de $1.217 \mathrm{~mm} /$ ano (Tabela 3). 
Tabela 3 - Precipitações médias mensais da Bacia Hidrográfica do Jacarecica (SE)

no período de 1913- 2012

\begin{tabular}{|c|c|c|c|c|c|c|c|c|c|c|c|c|c|c|}
\hline Município & & Jan & Fev & Mar & $\mathrm{Abr}$ & Mai & Jun & Jul & Ago & Set & Out & Nov & Dez & Total \\
\hline Itabaiana & $1913-2010$ & 29,12 & 33,89 & 56,73 & 104,6 & 147,8 & 142,6 & 135,1 & 95,22 & 55,45 & 36,7 & 33,19 & 29,6 & 899,98 \\
\hline Malhador & $1963-2005$ & 53,61 & 63,58 & 97,08 & 151,4 & 196,5 & 211,9 & 226,1 & 168,5 & 87,78 & 51,6 & 54,75 & 43,83 & 1406,52 \\
\hline Moita Bonita & $1995-2005$ & 51,73 & 41,92 & 39,52 & 156 & 176,1 & 201,5 & 185,4 & 149,5 & 54,95 & 47,97 & 47,83 & 32,56 & 1184,98 \\
\hline Riachuelo & 1963-1999 & 47,05 & 82,37 & 91,86 & 181,8 & 274,9 & 301,6 & 228,5 & 159,9 & 124,9 & 47,05 & 48,38 & 43,29 & 1631,45 \\
\hline Ribeirópolis & $1963-2005$ & 41,76 & 40,12 & 60,95 & 110,4 & 147,6 & 145,1 & 137,3 & 90,91 & 54,67 & 33,61 & 38,54 & 36,18 & 937,11 \\
\hline Santa Rosa de Lima & $1952-2012$ & 49,77 & 53,77 & 82,23 & 157,6 & 200,2 & 190,3 & 188,4 & 127,1 & 76,69 & 51,94 & 36,86 & 32,81 & 1247,64 \\
\hline \multicolumn{2}{|l|}{ Média } & 45,51 & 52,61 & 71,4 & 143,6 & 190,5 & 198,8 & 183,5 & 131,9 & 75,74 & 44,81 & 43,26 & 36,38 & \\
\hline
\end{tabular}

O extrato do balanço hídrico climatológico do período1950-2012 (Figura4) mostra que há excedente hídrico entre os meses de abril a agosto de 390,96 mm e déficit hídrico entre os meses de setembro a março de 486,75 mm, uma reposição hídrica de 99,28 mm nos meses de abril e maio.

Figura 4 - Balanço Hídrico Climatológico da Bacia Hidrográfica do Jacarecica (SE),segundo metodologia deTornthwaite\&Mather(1955) período 1952-2012.

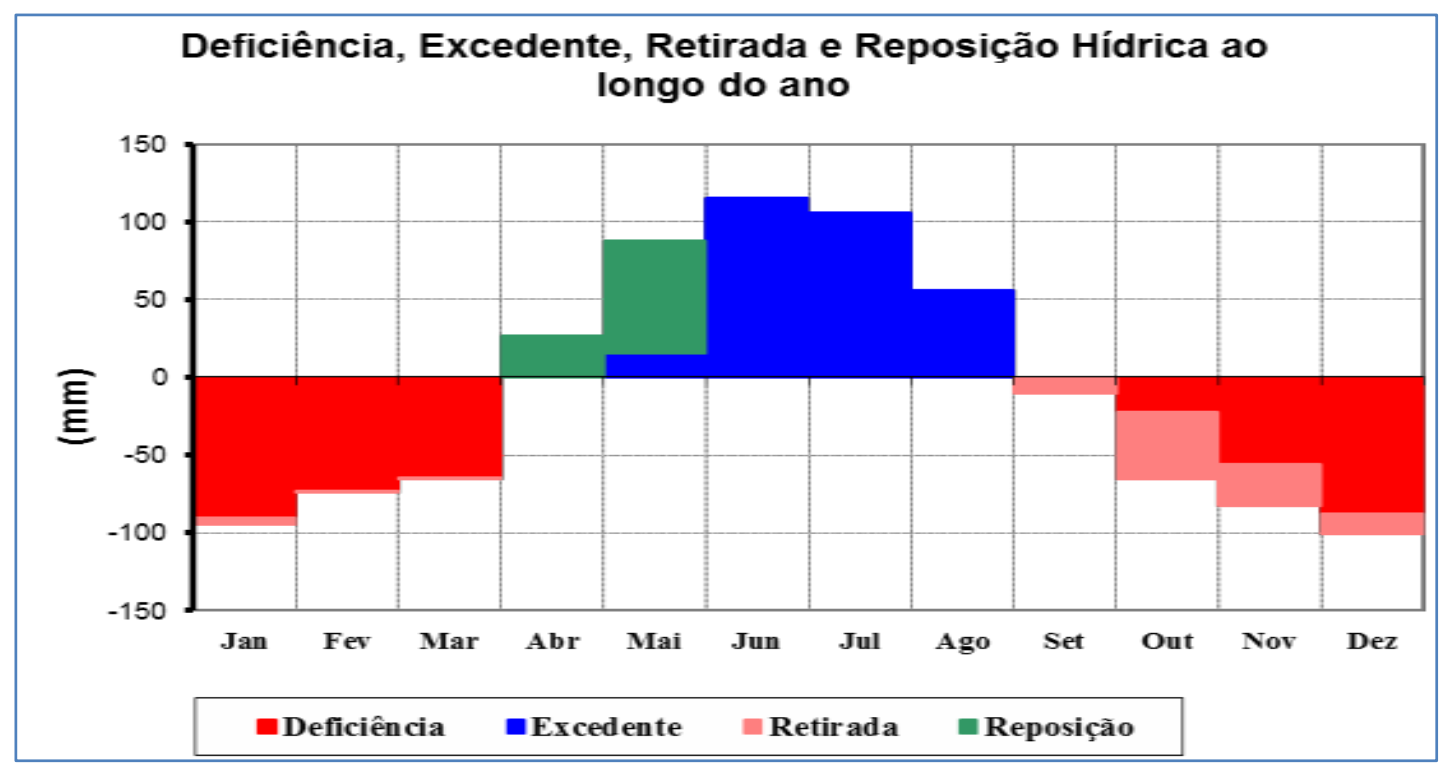

As isoietas das Precipitações Médias Anuais da Bacia do Jacarecica no período 1913 a 2012 (Figura 2) traçadas com intervalo de $100 \mathrm{~mm}$, apresentaram 5 faixas de precipitações que variam de 843,06 a 1406,52 $\mathrm{mm}$ ao longo dos 501,99 km2 da Bacia.

As menores precipitações são encontradas na região de Itabaiana e Ribeirópolis, precipitações que variam de 840 a $930 \mathrm{~mm}$, são municípios que fazem parte da zona climática do Agreste. Os maiores índices pluviométricos ocorrem entre os municípios de Moita Bonita até Riachuelo, sendo o município de Malhador o de maior precipitação na bacia, com mais de $1.400 \mathrm{~mm} /$ ano, municípios que fazem parte da zona climática do Litoral Úmido. A bacia apresenta variabilidade nas precipitações médias mensais, concordando com Lima \& Fontes, (2008).

Entre os anos mais chuvosos na região (no período estudado), tem-se encontrado: 1964, 1985, 1986,1989 e 2004, corrobora com mencionados por Marengo et. al., (2011) para região Nordeste. 
Figura2 - Mapa Isoietas das Precipitações Médias Anuais da Bacia Hidrográfica do Jacarecica - Período: 1913 a 2012.

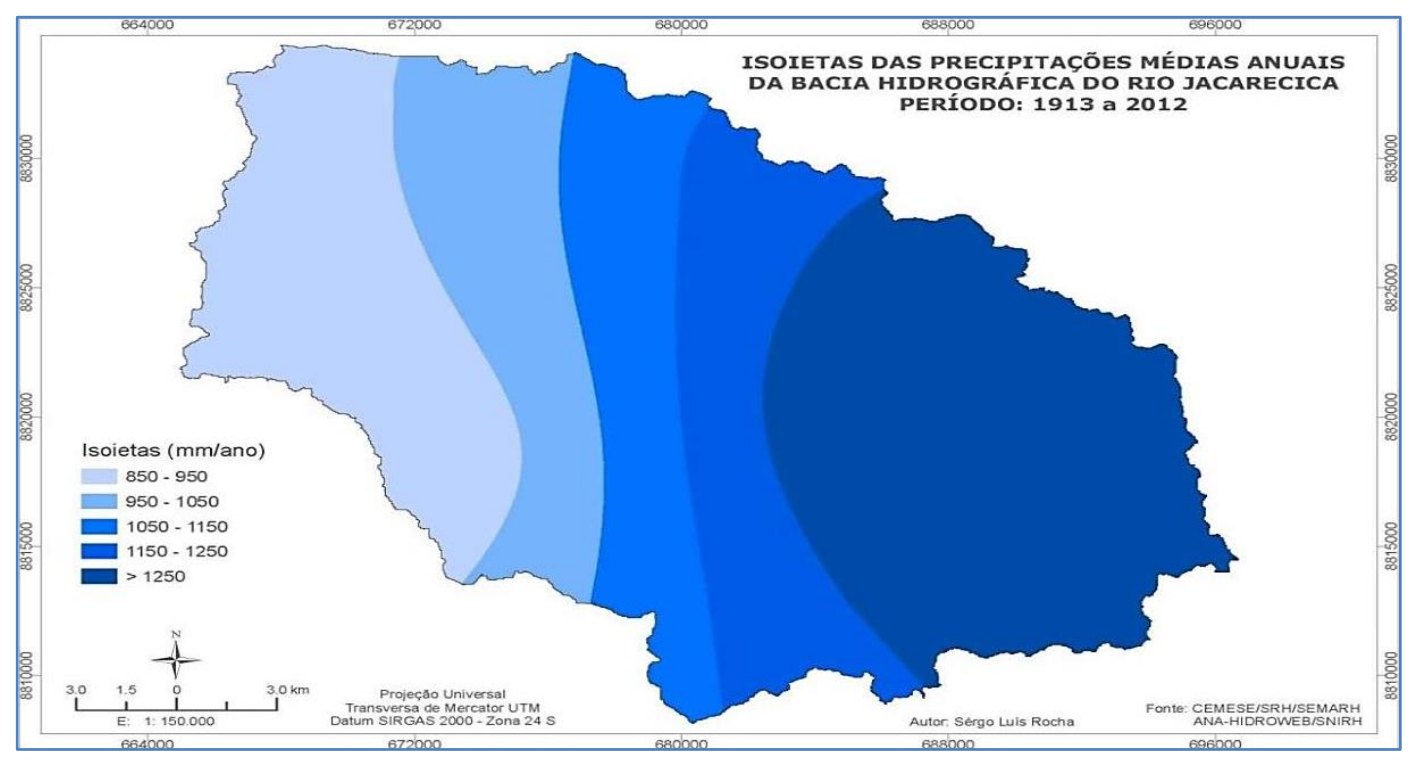

\section{CONCLUSÕES}

Podemos concluir que a classificação climática da Bacia Hidrográfica do Rio Jacarecicasegundo metodologia de Tornthwaite \& Mather(1955)é do tipo climático: Subúmido Seco (C1), Megatérmico, com Evapotranspiração Potencial média anual variando entre 1.158 à $1.436 \mathrm{~mm}$.

Apresenta excesso hídrico no inverno, ou déficit de água no verão. 0 clima dos seis municípios da Bacia apresentam características que são muitosimilares, devido principalmente a sua proximidade.

As maiores precipitações ocorrem entres os meses de março a agosto, sendo Junho considerado o mês mais chuvoso.

\section{AGRADECIMENTOS}

Ao Centro de Meteorologia de Sergipe - CEMESE/SRH/SEMARH na pessoa de Overland Amaral Costa e Aline Oliveira da Silva. Ao colega Sérgio Luis Rocha da SRH/SEMARH pela confecção dos mapas. As empresas EMDAGRO, (Adilson Cavalcante ASPLAN), COHIDRO-GEDEA pelo fornecimento de alguns dados de Itabaiana.

\section{REFERÊNCIAS}

[1] AYOADE, J. O. Introdução à climatologia para os trópicos. 4.ed. Rio de Janeiro: Bertrand Brasil, 1996. 322p

[2] ANA- Agência Nacional de Águas - Hidroweb. Disponível em:<http://hidroweb.ana.gov.br/>.Acesso em: 25 mar. 2013.

[3] BARROS, J. R.; ZAVATTINI, J. A. Bases Conceituais Em Climatologia Geográfica.

[4] Mercator-Revista de Geografia da UFC, Fortaleza, v. 8, n. 16, p. 255-261, 2009.

[5] CARVALHO, M. E. S.; FONTES, A. L. Estudo ambiental da zona costeira sergipana como subsídio ao ordenamento territorial. Geonordeste, São Cristóvão,ano 12, n.2, p. 10- 39, 2006.

[6] CAVALCANTI, E.P. ; SILVA, VICENTE DE P. R. ; SOUSA, FRANCISCO de A. S. de .

[7] Programa computacional para a estimativa da temperatura do ar para a região Nordeste do Brasil. Revista Brasileira de Engenharia Agrícola e Ambiental, Brasil, v. 10, n. 1, p. 140-147, 2006.

[8] CAVALCANTI, I. F. A.; FERREIRA, N. J.; SILVA, M. G. A. J.; SILVA DIAS, M. A. F. Tempo e Clima no Brasil. São Paulo: Oficina de Textos. 2009. 463p.

[9] COSTA, O. A.; SOUSA, I.F.; SANTOS, L.M.V. COSTA, A. G. Sistemas Atmosféricos atuantes no Nordeste do Brasil durante a estação de verão. In: XIII Congresso Brasileiro de Meteorologia, 13, 2004, Fortaleza, Anais. v.1. CDROM. 
[10] CUPOlillo, F. ; ABREU, M. ; VIANELlO, R. L. . Climatologia da Bacia do Rio Doce e sua Relação com a Topografia Local. Geografias, Belo Horizonte, v. 4, n. 1, p. 45-60, 2008.

[11] ESRI - ArcGis Desktop 10.0. Redlands (CA), 2013. Disponível em: <http://help.arcgis.com/en/arcgisdesktop/10.0/help/>. Acesso em: 12 jun.2013.

[12] FERREIRA, A.G. e MELLO, N.G.S. Principais Sistemas atmosféricos atuantes sobre a Região Nordeste do Brasil e a influência dos OceanosPacífico e Atlântico no clima da Região.Revista Brasileira de Climatologia. Curitiba, v, 1 n. 1, p 15-28, 2005.

[13] JURCA, J. Classificações climáticas: variações temporo-espaciais e suas aplicações nos livros didáticos e como subsídio ao zoneamento agroclimático. 2005. 100 f. Dissertação (Mestrado em Geografia) - Faculdade de Ciências e Tecnologia, Universidade Estadual Paulista,2005. Disponível em: <www4.fct.unesp.br/pos/geo/dis_teses/05/05_JANAINA_JURCA.pdf>. Acesso em: 01 mar. 2013.

[14] LIMA, A. S. \& FONTES, A. L. Aptidão Agrícola da Terra na Sub-Bacia do Rio Jacarecica- SE. Scientia Plena. São Cristóvão,v.4, n. 10. 2008.

[15] MARCUZZO, F. N, ANDRADE, L. R. \& MELO, D. C. R. Métodos de Interpolação Matemática no Mapeamento de Chuvas do Estado do Mato Grosso. Revista Brasileira de Geografia Física. Recife, v. 4. n. 4, p. 793-804, 2011.

[16] MARENGO J. A. ; ALVES, L. M ; BESERRA, E. ; LACERDA, F. . Variabilidade e mudanças climáticas no semiárido brasileiro. In: Salomão de Sousa Medeiros, Hans RajGheyi, Carlos de Oliveira Galvão, Vital Pedro da Silva Paz. (Org.). Recursos Hidricos e, Regiões Aridas e SemiAridas. Campina Grande, PB: INSA, 2011, v. , p. 383-416.

[17] MELO NETO, J. O. ; CHAGAS, R. M. ; JESUS, J. B. ; SANTOS, F. M. S. ; MELLO JUNIOR, A.

[18] V. . Delimitação das potenciais áreas de recarga subterrânea da bacia hidrográfica do Rio Jacarecica. In: III Encontro de Recursos Hídricos em Sergipe, 2010, Aracaju. III Encontro de Recursos Hídricos em Sergipe. Aracaju: EMBRAPA, 2010. v. 3. p. 1-4. CD- ROM.

[19] MENDONÇA, F.; DANNI-OLIVEIRA, I. M. Climatologia: noções básicas e climas do Brasil. São Paulo: Oficina de Texto, 2007. 206 p.

[20] MOLINIER, M.; ALBUQUERQUE, C.H. \& CADIER, E. Análise da pluviometria e isoietas homogeneizadas do Nordeste brasileiro. Recife, SUDENE, 1994. 58p. (Série Hidrologia, 32).

[21] NÓBREGA, R. S. Um pensamento crítico sobre classificações climáticas: de Köppen até Strahler. Revista Brasileira de Geografia Física, Recife,v. 3, n. 1, p. 18-22, 2010

[22] PEREIRA, A. P. Simplificando o balanço hídrico de Thornthwaite-Mather. Bragantia, Campinas, v. 64, n. 2, p. 311-313, 2005.

[23] PEREIRA, A. R.; ANGELOCCI, L.R. ; SENTELHAS, P. C.Apostila: Meteorologia Agrícola - 2007, (Edição Revista e Ampliada).ESALQ/USP 2007 202. 2007. em:<http://www.leb.esalq.usp.br/aulas/lce306/MeteorAgricola_Apostila2007.pdf>.A cesso em: 01 de abr.2013.

[24] PEREIRA, A.R.; ANGELOCCI, L.R.; SENTELHAS, P.C.Agrometeorologia: fundamentos e aplicações práticas. Guaíba: Agropecuária, 2002. $478 \mathrm{p}$

[25] PINTO, J. E. S. de S.; NETTO, A. de O. A. Clima, geografia e agrometeorologia: uma abordagem interdisciplinar. São Cristóvão: Editora UFS; Aracaju: Fundação Oviêdo Teixeira, 2008.

[26] ROLIM, G. S.; SENTELHAS, P. C.; BARBIERI, V. Planilhas no ambiente EXCEL para os cálculos de balanços hídricos: normal, sequencial, de cultura e de produtividade real e potencial. Revista Brasileira de Agrometeorologia, Santa Maria, v.6, p.133-137, 1998.

[27] SEMARH - Secretaria de Estado do Meio Ambiente e dos Recursos Hídricos. Superintendência de Recursos Hídricos. Atlas Digital sobre Recursos Hídricos. Aracaju: SMARH/SRH, v. 2013.3. DVD-ROM.

[28] SETTI, A. A., WERNECK LIMA, J. E. F., CHAVES, A. G. M., PEREIRA, I. C. 2001 -

[29] Introdução ao gerenciamento de recursos hídricos. Brasília: Agência Nacional de Energia Elétrica; Agência Nacional de Águas. 328 p.

[30] SNIRH - Sistema Nacional de Informações sobre Recursos Hídricos - Disponível em:<http://portalsnirh.ana.gov.br/Esta\%C3\%A7\%C3\%B5esdaANA/tabid/359/Default. aspx >.Acesso em: 25 de mar.2013.

[31] TORNTHWAITE, C. W.; MATTER, J. R. The water balance . Centerton, N. J. DrexelInstituteof Technology, 1955. $104 \mathrm{p}$.

[32] TUCCI, C. E. M. ; BRAGA, B. Clima e Recursos Hídricos. In:Clima e Recursos Hídricos no Brasil, TUCCI, C. E. M. ; BRAGA, B. (Org.) Porto Alegre: ABRH GWP ANA, 2003. v. 9. 350p. 


\title{
CAPÍTULO 03 Utilização do atlas de recursos hídricos do estado de Sergipe para mapeamento das áreas de preservação permanente em margens de corpos d'água da bacia do rio Jacarecica
}

\author{
Igor Pinheiro da Rocha \\ José Antonio Pacheco de Almeida
}

\section{INTRODUÇÃO}

A Bacia Hidrográfica do rio Jacarecica é uma das sub-bacias do rio Sergipe e está localizada no Território Agreste Central Sergipano, integrando parcialmente os municípios de Ribeirópolis, Itabaiana, Moita Bonita, Santa Rosa de Lima, Areia Branca e Riachuelo, e totalmente, o município de Malhador. De acordo com SOS Mata Atlântica (2008) a formação vegetal original da sub-bacia é compartilhada entre os biomas Mata Atlântica e Caatinga. Dentro do bioma Mata Atlântica a principal fisionomia vegetal é a Floresta Estacional Semidecidual, restrita aos municípios Santa Rosa de Lima, Malhador e Riachuelo. Já o bioma Caatinga abrange os demais municípios ocupando uma área de aproximadamente $70 \%$ da bacia com a formação Caatinga Hiperxerófita. A vegetação desta bacia tem sofrido alterações em sua fisionomia e densidade original desde o período colonial, quando grande parte da sua área original foi fragmentada e substituída por culturas agrícolas, em especial a cana- de-açúcar (LOUREIRO, 1999).

Dentre os diferentes tipos de vegetação que ocorre numa bacia hidrográfica há aquela que se desenvolve nas condições especificas das margens dos cursos d'água e em suas planícies de inundação. No Brasil, esta vegetação possui inúmeras denominações, sendo o mais apropriado tratá-la como vegetação ripária (KOBIYAMA, 2003). 0 autor elaborou um trabalho de revisão sobre os diferentes termos correlatos ao espaço próximo a corpos d’água em bacias hidrográficas, e concluiu que o termo zona ripária é o mais apropriado, sendo definido como um espaço tridimensional que contém vegetação, solo e rio. Sua extensão horizontal é definida pelo alcance da inundação, e verticalmente do regolito (abaixo) até o topo da copa da floresta (acima).

A vegetação neste espaço recebe influência direta do curso d'água e desempenha diversas funções que proporcionam condições ecológicas locais particularmente adaptadas, importantes para a manutenção da qualidade da bacia hidrográfica (PEREIRA e LEITE, 1996; LIMA e ZAKIA, 2004).

Do ponto de vista ecológico, as zonas ripárias tem sido consideradas como corredores extremamente importantes para o movimento da fauna ao longo da paisagem, assim como para a dispersão vegetal. Esta função já é, sem dúvida, razão suficiente para justificar a necessidade da conservação das florestas ripárias. No entanto, Lima (1989) defendeu que se deve adicionar a função hidrológica das zonas ripárias na manutenção da integridade da microbacia hidrográfica, representada pela geração do escoamento superficial em microbacias, quantidade e qualidade da água, ciclagem de nutrientes e interação direta com o ecossistema aquático. A rugosidade das margens proporcionada pela vegetação ripária e pela queda de galhos e troncos (resíduos grosseiros) favorecem o processo de deposição de partículas e sedimentos, e criando, também, micro habiltat favoráveis para alguns organismos aquáticos.

Além disso, a cobertura vegetal tem uma importância fundamental no equilíbrio hídrico e sedimentológico da bacia, pois facilita a infiltração de água no solo, reduzindo o escoamento superficial e, consequentemente, a erosão da camada superficial do solo. Retendo e absorvendo água do escoamento superficial, a floresta, juntamente com a serrapilheira, evita a turbidez excessiva da água e o assoreamento dos leitos dos rios e das nascentes. A taxa de infiltração de água no solo florestal pode ser 
de 10 a 15 vezes maior do que em uma pastagem e 40 vezes mais que em solo descoberto (DAVIDE et al; 2000). Segundo os autores, esta infiltração recarrega os aquíferos subterrâneos, assegura a perenidade das fontes e nascentes, melhora a qualidade e aumenta o volume de água para consumo humano e agrícola.

Todavia, Gregory et al. (1992) chamaram atenção para o fato de que os processos físicos que alteram continuamente os leitos dos cursos d'água possuem temporalidade variada. Os autores explicaram que estes processos podem ocorrer em curtos intervalos de tempo, como nos eventos de cheias anuais, e em fenômenos mais intensos, como nas enchentes decenais e seculares. Desta forma, concluíram que é preciso, também, considerar um padrão temporal de variação destas zonas.

Devido a esta elevada frequência de alterações que ocorrem na zona ripária, Lima e Zakia (2004) destacaram que a vegetação que normalmente a ocupa deve, em geral, apresentar uma alta variação em termos de estrutura, composição e distribuição espacial. Ainda, esta variação deve ocorrer tanto ao longo do curso d'água, refletindo variações de micro-sítios resultantes da dinâmica dos processos fluviomórficos (erosão e deposição), como lateralmente, onde a condição de umidade do solo diminui à medida que se aumenta a distância do canal, o que deve influenciar a composição das espécies, por sua vez.

Embora as zonas ripárias sejam áreas reconhecidamente dinâmicas e dependentes das características ambientais que as cercam, o aparato legal brasileiro, que tem por objetivo proteger e disciplinar o uso destes espaços, procura padronizar a demarcação das áreas de preservação permanente baseando-se principalmente na largura dos corpos d'água.

Contudo, o objetivo deste trabalho foi demarcar as áreas de preservação permanente ao redor de corpos d'água e nascentes da bacia hidrográfica do rio Jacarecica observando estritamente a atual legislação brasileira.

\section{DESENVOLVIMENTO}

Os produtos foram gerados a partir do banco de dados geográfico do Atlas Digital Sobre Recursos Hídricos de Sergipe (SERGIPE, 2012) e do Mapa de Cobertura Vegetal dos Biomas Brasileiros (BRASIL, 2013). Os arquivos shape de ambos os bancos de dados foram manipulados com o auxílio do software ArcGIS, versão 9.3, para obtenção dos mapas temáticos das Áreas de Preservação Permanente que ocorrem ao longo dos corpos d'água e das nascentes da bacia.

\section{BIOMAS DA BACIA HIDROGRÁFICA DO RIO JACARECICA}

No banco de dados geográfico do Mapa de Cobertura Vegetal dos Biomas Brasileiros (BRASIL, 2013) foram obtidos os temas referentes aos biomas Caatinga e Mata Atlântica. Para ambos os temas foram utilizadas as cartas Aracaju, folha SC-24-Z-B, ano base 2002, das quais foram extraídas e unidas as respectivas regiões fitoecológicas pertencentes a cada bioma inserido na bacia do rio Jacarecica. Com isso, um novo arquivo shape foi criado, o qual deu origem ao mapa temático Biomas da bacia do rio Jacarecica, na escala 1:150.000 (Figura 1).

A área total da bacia é de 507,29 $\mathrm{km}^{2}$, entretanto, somente o bioma Caatinga ocupa 70,11\% desta área, o equivalente a $355,65 \mathrm{~km}^{2}$, enquanto o bioma Mata Atlântica possui uma área de $151,63 \mathrm{~km}^{2}$, correspondente a $29,89 \%$ da área da bacia. 
Figura 1. Mapa temático Biomas da bacia do rio Jacarecica.

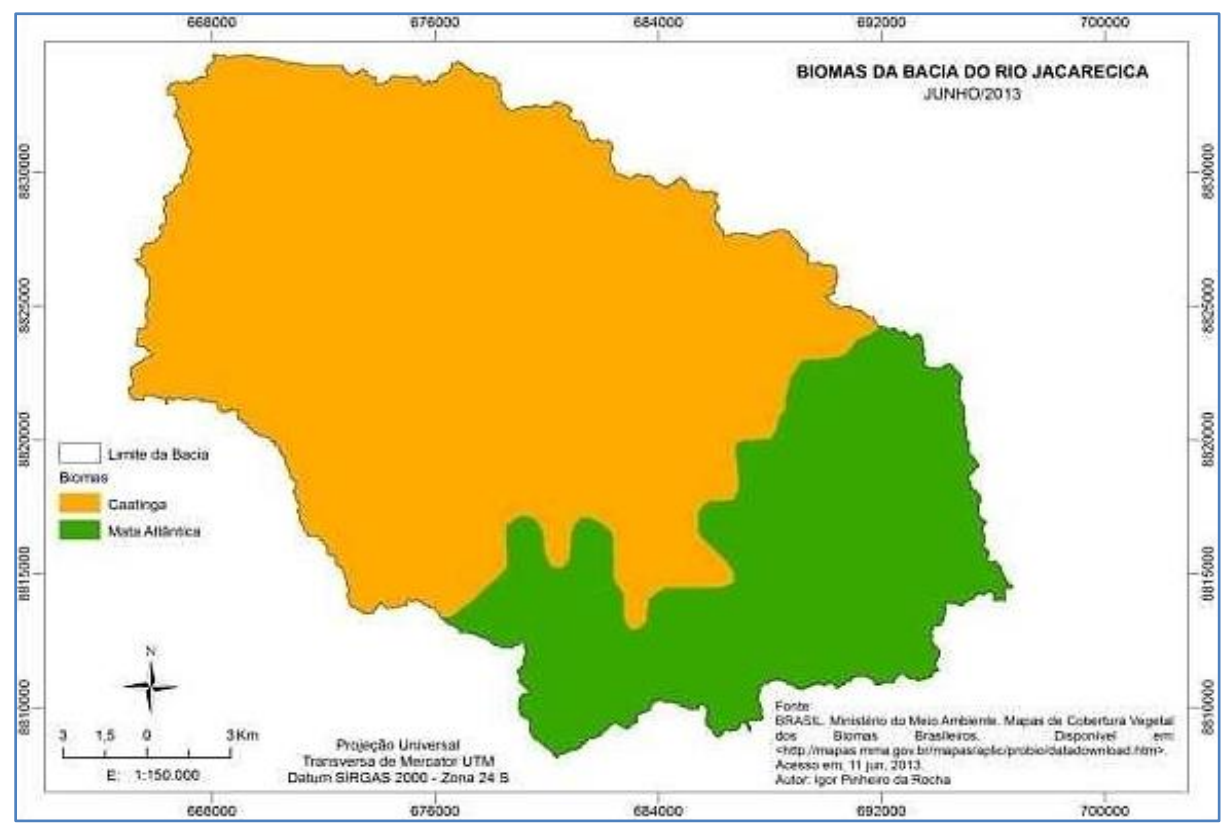

\section{DEMARCAÇÃO DAS ÁREAS DE PRESERVAÇÃO PERMANENTE AO LONGO DOS CURSOS D'ÁGUA}

O mapa temático das Áreas de Preservação Permanente das margens de cursos d'água da bacia do rio Jacarecica foi elaborado a partir das definições, parâmetros e limites dispostos na Lei no 12.651 , de 2012, de acordo com o texto da referida lei:

Art. 3o Para os efeitos desta Lei, entende-se por: [...]

XIX - leito regular: a calha por onde correm regularmente as águas do curso d'água durante o ano; *...+

Art. 4o Considera-se Área de Preservação Permanente, em zonas rurais ou urbanas, para os efeitos desta Lei:

I - as faixas marginais de qualquer curso d'água natural perene e intermitente, excluídos os efêmeros, desde a borda da calha do leito regular, em largura mínima de:

30 (trinta) metros, para os cursos d'água de menos de 10 (dez) metros de largura;

50 (cinquenta) metros, para os cursos d'água que tenham de 10 (dez) a 50 (cinquenta) metros de largura;

100 (cem) metros, para os cursos d'água que tenham de 50 (cinquenta) a 200 (duzentos) metros de largura;

200 (duzentos) metros, para os cursos d'água que tenham de 200 (duzentos) a 600 (seiscentos) metros de largura;

500 (quinhentos) metros, para os cursos d'água que tenham largura superior a 600 (seiscentos) metros;

Para determinação das áreas de preservação permanente ao longo dos cursos d'água da bacia do rio Jacarecica no ArcGIS 9.3, foi utilizado o arquivo shape representativo da hidrografia da bacia, obtido no banco de dados geográfico do Atlas Digital Sobre Recursos Hídricos de Sergipe (SERGIPE, 2012). Com o uso da ferramenta Buffer foi possível conhecer as áreas de preservação permanente. No entanto, em termos de largura, considerando a heterogeneidade dos cursos d'água da bacia, para a correta aplicação 
da largura da APPs conforme a legislação, foram realizadas medições da largura da borda da calha do leito regular in loco, com o uso de trena graduada, seguindo uma amostragem aleatória onde foram visitados 50 pontos de conferência dos 649 trechos do rio, o correspondente a 7,7\%. Desta forma, foi possível configurar a ferramenta buffer do aplicativo para responder conforme as exigências legais e, com isso, gerar o mapa temático das Áreas de Preservação Permanente das margens de cursos d'água da bacia do rio Jacarecica, em escala 1:150.000, (Figura 2) mais coerente com a realidade.

Figura 2. Mapa temático das Áreas de Preservação Permanente das margens de cursos d'água da bacia do rio Jacarecica

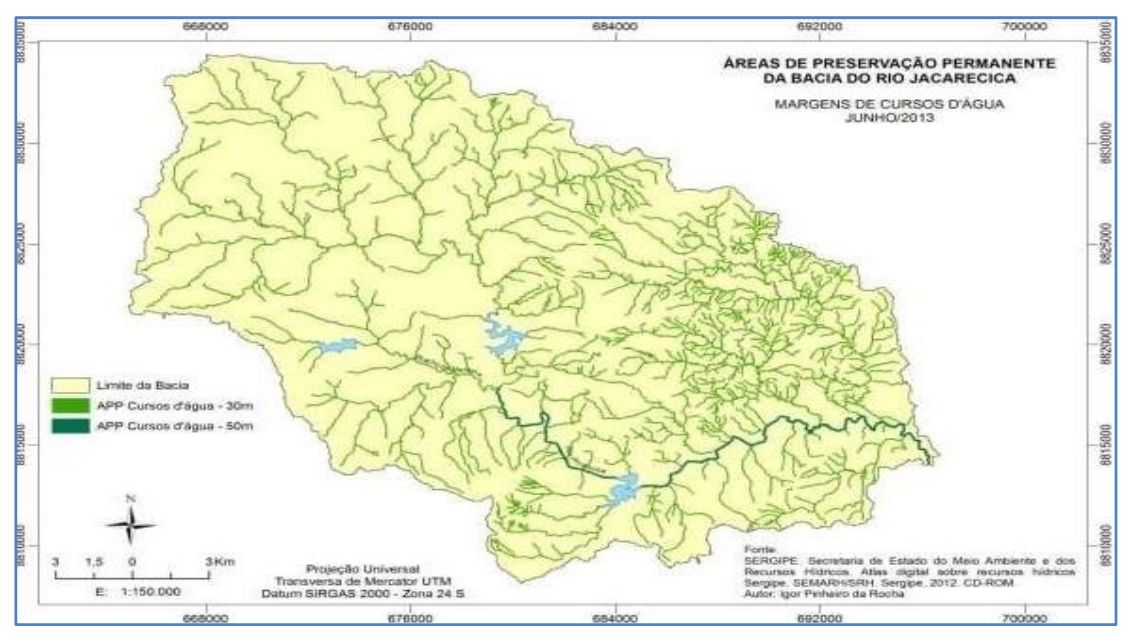

A largura dos cursos d'água nos pontos amostrados variou entre 1,9 e 24,20m, desta forma, observando a legislação, a bacia do rio Jacarecica deve possuir somente áreas de preservação permanente ao longo dos cursos d'água com larguras iguais a 30 e 50m. Conforme pode ser observado na Figura 2, as áreas de preservação permanente ao longo dos cursos d'água com largura de 50 metros, totalizando 3,16 km², ocorrem desde a foz do rio Jacarecica até o ponto de deságue do riacho da Marcela no rio Jacarecica. Isto pode ser explicado devido ao fato de o riacho da Marcela ser um dos principais tributários do rio Jacarecica, contribuindo para um significativo aumento do volume de água no rio principal à jusante do encontro e consequentemente aumentando a largura da sua seção molhada.

À montante do referido ponto, estima-se, com base na amostragem realizada, que os demais cursos d'água possuem largura inferior a $10 \mathrm{~m}$, e, portanto, devem apresentar APPs com 30 metros de largura. Estas áreas somadas perfazem um total de $53,09 \mathrm{~km}^{2}$, ou 10,46\% da área total da bacia.

\section{DEMARCAÇÃO DAS ÁREAS DE PRESERVAÇÃO PERMANENTE AO REDOR DE NASCENTES}

O mapa temático Áreas de Preservação Permanente ao redor de nascentes foi elaborado a partir das seguintes definições, parâmetros e limites dispostos na Lei no 12.651 , de 2012:

"Art. 3oPara os efeitos desta Lei, entende-se por: [...]

- nascente: afloramento natural do lençol freático que apresenta perenidade e dá início a um curso d'água;

- olho d'água: afloramento natural do lençol freático, mesmo que intermitente; [...]

Art. 4o Considera-se Área de Preservação Permanente, em zonas rurais ou urbanas, para os efeitos desta Lei: [...]

IV - as áreas no entorno das nascentes e dos olhos d'água perenes, qualquer que seja sua situação topográfica, no raio mínimo de 50 (cinquenta) metros;"

Para a determinação destas áreas de preservação foi utilizado foi utilizado o arquivo shape representativo da hidrografia da bacia, obtido no banco de dados geográfico do Atlas Digital Sobre 
Recursos Hídricos de Sergipe (SERGIPE, 2012). Com o uso da ferramenta Feature Vertices To Points, do ArcToolbox, foi possível criar um novo arquivo shape no qual foram automaticamente gerados os pontos na extremidade à montante de cada curso d'água, representando assim as nascentes da bacia hidrográfica. Assim, foi aplicada a ferramenta buffer com raio de 50 metros para determinação das áreas de preservação permanente e gerado o mapa temático Áreas de Preservação Permanente ao redor de nascentes (Figura 3).

Figura 3. Mapa temático das Áreas de Preservação Permanente ao redor de nascentes da bacia do rio Jacarecica.

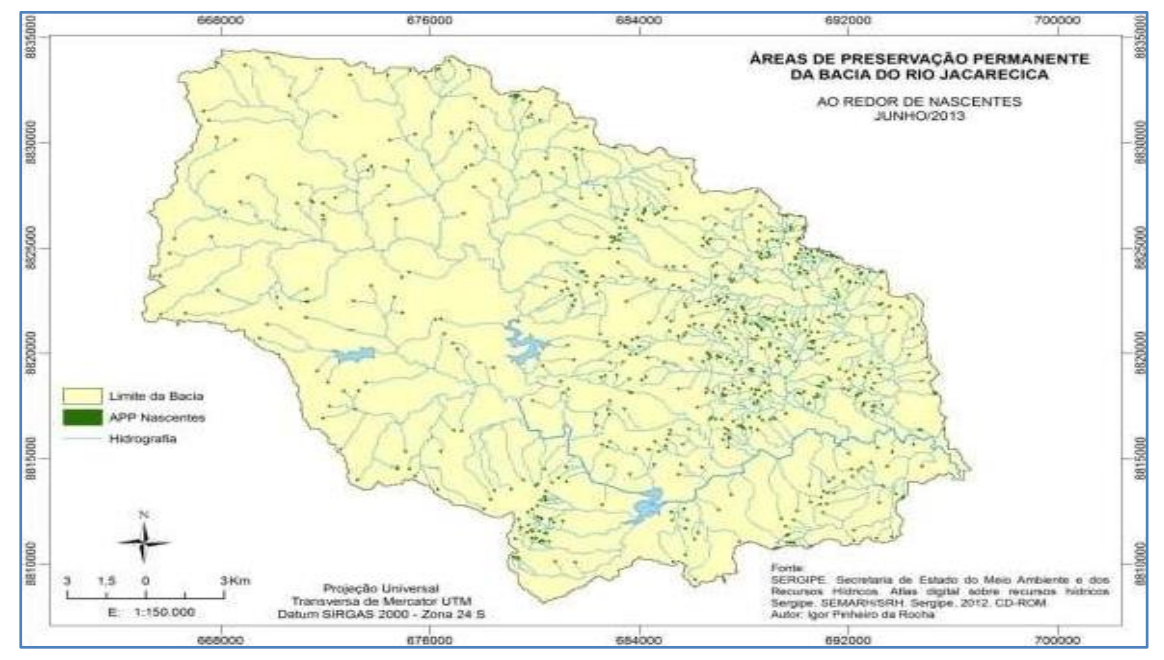

Ao todo são visualizadas 614 nascentes, que somadas suas áreas de preservação permanente têm-se uma área equivalente a $5,07 \mathrm{~km}^{2}$, aproximadamente $1 \%$ da área total da bacia. Percebe-se que ocorre maior concentração de nascentes na porção Nordeste da bacia, o que pode estar associado à zona climática daquela região, apresentada por Rocha (2013) como sendo Litoral Úmido, e à sua formação geológica, composta pelas unidades Barreiras, Frei Paulo - unidade 1 e Ribeirópolis, de acordo com Santos et al. (2001).

\section{DEMARCAÇÃo DAS ÁREAS DE PRESERVAÇÃO PERMANENTE AO REDOR DE LAGOS E RESERVATÓRIOS}

A partir das seguintes definições, parâmetros e limites dispostos na Lei no 12.651 , de 2012 foi elaborado o mapa de Áreas de Preservação Permanente ao redor de lagos e reservatórios pertencentes à bacia do rio Jacarecica, de acordo com o texto da referida lei:

“Art. 4o Considera-se Área de Preservação Permanente, em zonas rurais ou urbanas, para os efeitos desta Lei: [...]

- as áreas no entorno dos lagos e lagoas naturais, em faixa com largura mínima de:

100 (cem) metros, em zonas rurais, exceto para o corpo d'água com até 20 (vinte) hectares de superfície, cuja faixa marginal será de 50 (cinquenta) metros;

30 (trinta) metros, em zonas urbanas; [...]

- as áreas no entorno dos reservatórios d'água artificiais, decorrentes de barramento ou represamento de cursos d'água naturais, na faixa definida na licença ambiental do empreendimento;

XI - em veredas, a faixa marginal, em projeção horizontal, com largura mínima de 50 (cinquenta) metros, a partir do espaço permanentemente brejoso e encharcado. 
§ 1o Não será exigida Área de Preservação Permanente no entorno de reservatórios artificiais de água que não decorram de barramento ou represamento de cursos d'água naturais. *...+

§ 4o Nas acumulações naturais ou artificiais de água com superfície inferior a 1 (um) hectare, fica dispensada a reserva da faixa de proteção prevista nos incisos II e III do caput, vedada nova supressão de áreas de vegetação nativa, salvo autorização do órgão ambiental competente do Sistema Nacional do Meio Ambiente - Sisnama.[...]

Art. 5o Na implantação de reservatório d'água artificial destinado a geração de energia ou abastecimento público, é obrigatória a aquisição, desapropriação ou instituição de servidão administrativa pelo empreendedor das Áreas de Preservação Permanente criadas em seu entorno, conforme estabelecido no licenciamento ambiental, observando-se a faixa mínima de 30 (trinta) metros e máxima de 100 (cem) metros em área rural, e a faixa mínima de 15 (quinze) metros e máxima de 30 (trinta) metros em área urbana."

A determinação das APPs ao redor de lagos e reservatórios foi realizada a partir do arquivo shape representativo dos reservatórios e lagos da bacia, obtido no banco de dados geográfico do Atlas Digital Sobre Recursos Hídricos de Sergipe (SERGIPE, 2012).

Com o uso da ferramenta Buffer aplicada sobre esta feição foi possível elaborar o mapa temático Áreas de Preservação Permanente ao redor de lagos e reservatórios da bacia (Figura 4).

Figura 4. Mapa temático das Áreas de Preservação Permanente ao redor de lagos e reservatórios da bacia do rio Jacarecica.

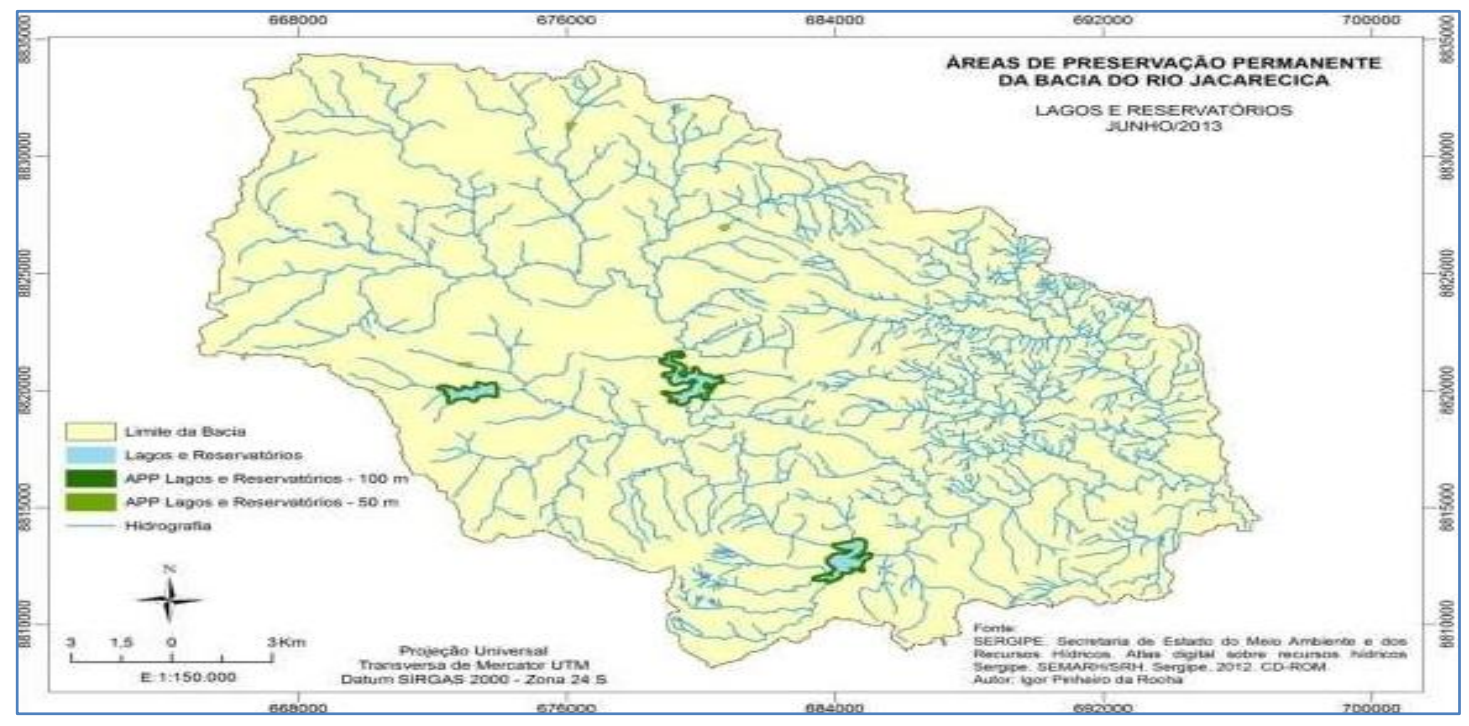

É importante destacar que todos os espelhos d'água apresentados na Figura 4 são classificados como reservatórios d'água artificiais, decorrentes de barramento ou represamento de cursos d'água naturais, conforme o inciso III do parágrafo 4ํ da Lei no 12.651 (BRASIL, 2012). Para a correta determinação das APPs seria necessário ter acesso às Licenças de Operação de tais empreendimentos. Como tal acesso não foi possível por questões burocráticas do órgão estadual representante do Sisnama, optou-se por estabelecer o limite mínimo para lagos e lagoas naturais.

Em tempo, observam-se 8 corpos d'água contidos na bacia, perfazendo área total de preservação igual a 2,85 $\mathrm{km}^{2}$, dos quais, de acordo com a legislação, 3 possuem APPs com largura de $50 \mathrm{~m}$, representando $0,14 \mathrm{~km}^{2}, 3$ possuem APPs com largura de $100 \mathrm{~m}$, representando 2,71 km², e 2 estão dispensados da faixa de proteção (Figura 5). 
Figura 5. Reservatórios isentos de Área de Proteção Permanente na bacia do rio Jacarecica.

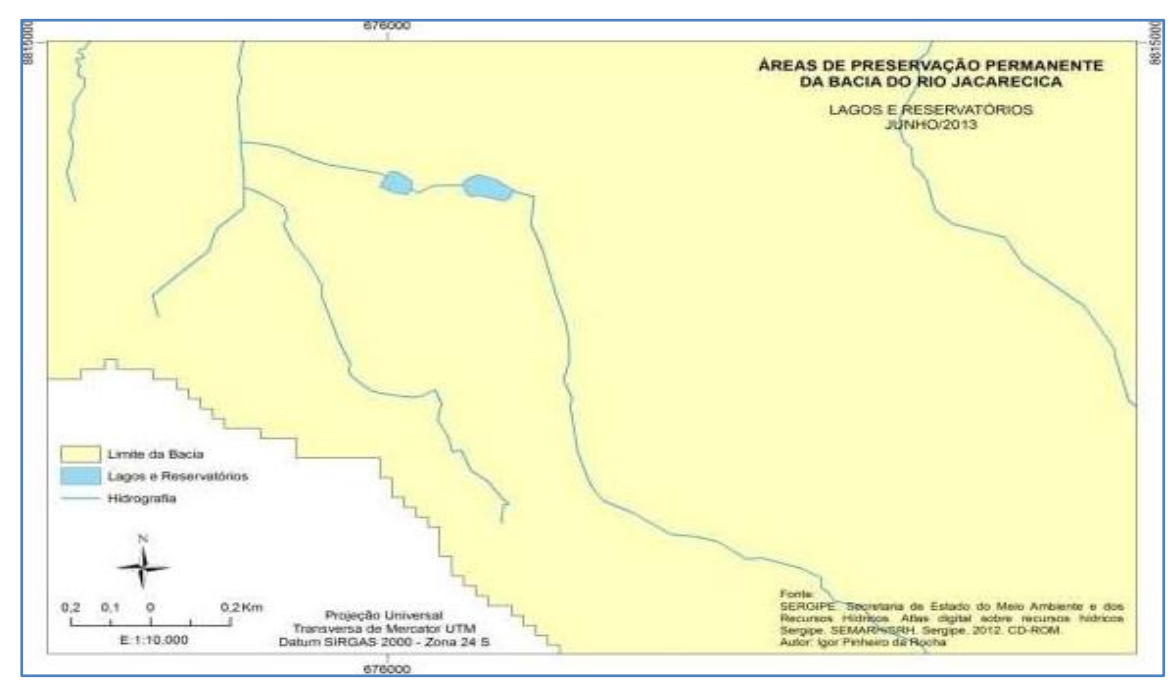

Estes dois reservatórios estão situados na porção Noroeste da bacia, mais especificamente no município de Itabaiana, somados representam aproximadamente $1 \mathrm{~km}^{2}$ de superfície.

\section{7 ÁREAS DE PRESERVAÇÃO PERMANENTE DA BACIA}

Unindo todos os mapas temáticos foi possível visualizar todas as áreas de preservação permanente da bacia do rio Jacarecica e gerar um novo mapa temático compilado. 0 valor total das APPs encontrado neste trabalho soma uma área de $64,17 \mathrm{~km}^{2}$, o equivalente a $12,64 \%$ da área da bacia (Figura 6).

Figura 6. Áreas de Preservação Permanente da bacia.

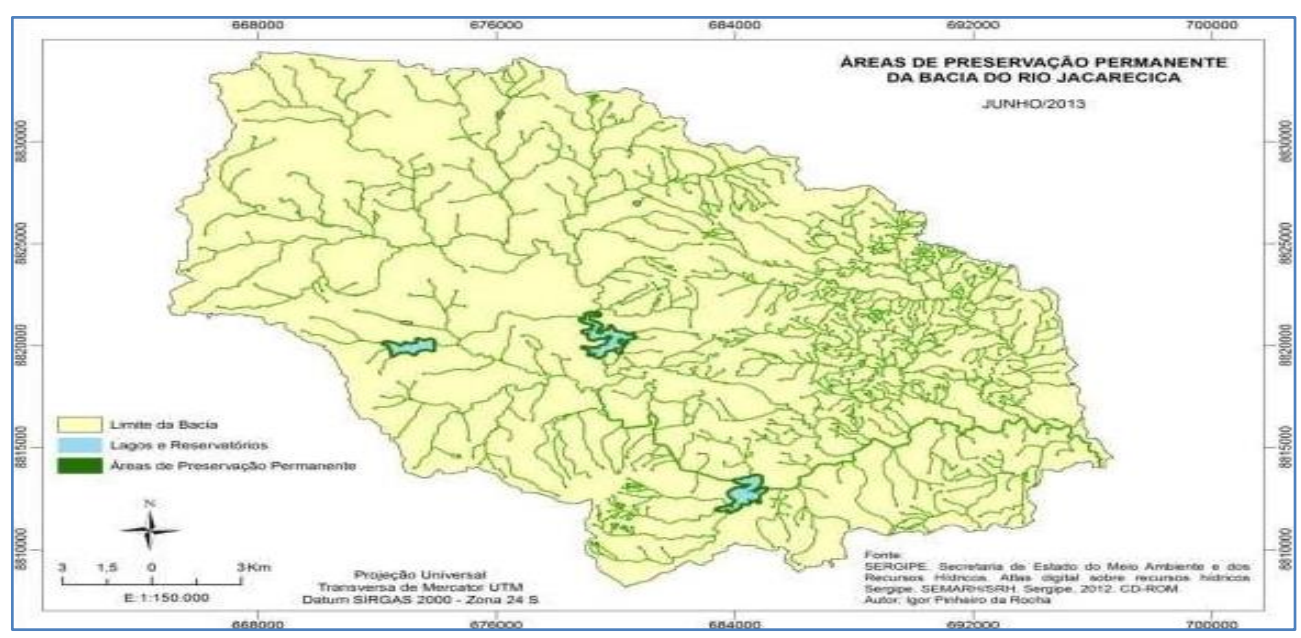

\section{CONSIDERAÇÕES FINAIS}

Percebe-se que a maior concentração de áreas de preservação permanente ocorre no bioma Mata Atlântica, especialmente na porção Nordeste da bacia. Esta ocorrência pode estar associada ao clima e à geologia da região.

A demarcação de áreas de preservação permanente com o auxílio do Software ArcGIS, versão 9.3, se mostrou uma metodologia simples de ser executada, porém de grande utilidade para quantificação das áreas que devem ser protegidas por lei. 
Este recurso pode ser utilizado por tomadores de decisões para, aliado a um trabalho de diagnóstico de remanescentes florestais em campo, auxiliar o planejamento de ações na bacia hidrográfica, podendo, por exemplo, ajudar a indicar áreas prioritárias para execução de projetos de recuperação florestal.

É importante destacar que este trabalho abordou somente as APPs ao longo de corpos d'água (rios, lagos e reservatórios) e APPs ao redor de nascentes. Não obstante, a legislação brasileira contempla outras formas de APPs, como os topos de morros, encostas com declividade maior que 45으, entre outras.

\section{REFERÊNCIAS}

[1] BOLFE, E. L. Geoprocessamento e sensoriamento remoto aplicados à análise de recursos florestais. Ciência Rural, v.34, n.1, 2004, p.105-111.

[2] BRASIL. Lei no 12.651, de 25 de maio de 2012. Diário Oficial [da] República Federativa do Brasil, Poder Executivo, Brasília, DF, 28 mai. 2012. Seção 1. p.1-8.

[3] BRASIL. Ministério do Meio Ambiente. Mapas de Cobertura Vegetal dos Biomas Brasileiros. Disponível em: <http://mapas.mma.gov.br/mapas/aplic/probio/datadownload.htm>. Acesso em: 11 jun, 2013.

[4] DAVIDE, A. C.; FERREIRA, R. A.; FARIA, F. M. R.; BOTELHO, S. A. Restauração de matas ciliares. Informe Agropecuário, Belo Horizonte, v.21, n.207, p.65- 74, 2000.

[5] GREGORY, S. V.; SWANSON, F. J.; McKEE, W. A.; CUMMINS, K. W. An ecosystem perspective of riparian zones. BioScience, v.41, n.8, p.540-551, 1992.

[6] KOBIYAMA, M. Conceitos de zona ripária e seus aspectos geobiohidrológicos. In: SEMINÁRIO DE HIDROLOGIA FLORESTAL: ZONAS RIPÁRIAS, I, 2003,

[7] Alfredo Wagner. Anais... Pós-Graduação em Engenharia Ambiental - PPGEAUFSC, Florianópolis. 2003. Versão eletrônica.

[8] LIMA, W. P. Função hidrológica da mata ciliar. In: SIMPÓSIO SOBRE MATA CILIAR, 1., 1989, Campinas. Anais... Campinas: Fundação Cargil, 1989. p 25-42.

[9] LIMA, W. P.; ZAKIA, M. J. B. Hidrologia de matas ciliares. In: RODRIGUES, R. R.; LEITÃO FILHO, H. F. (ed.). Matas Ciliares: Conservação e recuperação. São Paulo: EDUSP, FAPESP, 2.ed. 2004.

[10] LOUREIRO, K. A. S. Arquitetura Sergipana do Açúcar. Aracaju: Unit, 1999.

[11] PEREIRA, R. C.; LEITE, H. G. Considerações sobre o Manejo Sustentável de Matas Ciliares. In: SIMPÓSIO INTERNACIONAL SOBRE ECOSSISTEMAS

[12] FLORESTAIS, 4., 1996, Belo Horizonte. Volume de resumos. Belo Horizonte: Biosfera, 1996, p. 222 e 223.

[13] ROCHA, S. L. Análise Morfométrica da Bacia Hidrográfica do Rio Jacarecica utilizando o aplicativo ArcHydro Tools. 2013. 30f. Trabalho de conclusão de curso (Especialização) - Departamento de Engenharia Agronômica, Universidade Federal de Sergipe, São Cristóvão, 2013.

[14] SAnTos, R. A.; MARTinS, A. A. M.; NEVES, J. P.; LEAL, R. A. (Orgs.) Programa Levantamentos Geológicos Básicos do Brasil - PLGB. Geologia e recursos minerais do Estado de Sergipe. Escala 1:250.000. Texto explicativo do Mapa geológico do Estado de Sergipe. Brasília: CPRM/DIEDIG/DEPAT; CODISE, 2001.

[15] SERGIPE. Secretaria de Estado do Meio Ambiente e dos Recursos Hídricos. Atlas digital sobre recursos hídricos Sergipe. SEMARH/SRH. Sergipe, 2012. CD- ROM.

[16] SOS MATA ATLÂNTICA. Atlas dos Remanescentes Florestais da Mata Atlântica Período de 2000-2005. São Paulo: SOS Mata Atlântica, 2008. 


\title{
CAPÍTULO 04 Avaliação da qualidade da água do
açude da Marcela na sub-bacia
hidrográfica do rio Jacarecica - SE
}

\author{
Karine Resende Araújo \\ Elisangela de Andrade Passos \\ Carlos Alexandre Borges Garcia
}

\section{INTRODUÇÃO}

As questões ambientais ocupam um lugar de destaque nos meios de comunicação, nas ações governamentais e inclusive nas entidades educacionais, mas neste cenário, além da tendência de escassez devido à crescente demanda da água, o aspecto de ordem qualitativa, especialmente nas regiões de maior concentração de demandas hídricas aparece como um fator agravante, frente ao comprometimento dos mananciais de abastecimento, pela poluição resultante dos efluentes originados dos diversos usos e ocupação inadequados (BARBOSA,2002).

Considerada um recurso estratégico para a humanidade, a água mantém a vida no planeta, sustenta a biodiversidade, a produção de alimentos e suporta todos os ciclos naturais. Atualmente, a escassez dos recursos hídricos nos aspectos quantitativos e qualitativos, em várias regiões do mundo tem levado à percepção da necessidade de controle dos diferentes tipos de usos. Essa degradação aponta para mudanças substanciais na direção do planejamento, gerenciamento de águas superficiais e subterrâneas, regulando-os de forma a assegurar a sua disponibilidade futura (PRADO,2004).

Segundo Watanabe et al. (1999), a maioria dos reservatórios que existe no Nordeste do Brasil tem mais de noventa anos, mas, apesar de sua importância, não se sabe muito sobre eles. Os Estudos Integrados de Pesquisas Hidrológicas do Projeto Nordeste calculam que o número de barragens na região está entre cinqüenta mil e setenta mil, o que demonstra a importância social destes reservatórios.

Para Prado (2004), a situação é delicada, pois impactos negativos consideráveis, como a redução da capacidade de depuração do curso d'água, o aumento da capacidade de retenção de sedimentos e nutrientes e a alteração das características físicas, químicas e biológicas do sistema ocorrem na parte aquática. Fatores como estes, podem levar a um incremento do processo de eutrofização e dependendo do nível atingido, comprometer os usos múltiplos a que é destinado o reservatório, afetando assim a sustentabilidade dos sistemas do seu entorno.

Essas alterações podem produzir impactos estéticos, fisiológicos - distúrbios em organismos aquáticos causados pela variação de amônia - ou ecológicos. O conceito de poluição da água torna-se cada vez mais amplo em função de maiores exigências com relação à conservação e ao uso racional dos recursos hídricos (BRAGA et al., 2002).

A Resolução CONAMA № 357, de 17 de Março de 2005, que dispõe sobre a classificação dos corpos de água e diretrizes ambientais para o seu enquadramento, estabelece as condições e padrões de lançamento de efluentes, sendo esta, utilizada na avaliação de ecossistemas aquáticos. A Resolução CONAMA N ${ }^{\circ} 410 / 2009$ prorroga o prazo para complementação das condições e padrões de lançamento de efluentes, previsto no art. 44 da Resolução no 357/2005, e no art. 3o da Resolução no 397/2008 e a Resolução CONAMA N ${ }^{\circ} 430 / 2011$ dispõe sobre condições e padrões de lançamento de efluentes, complementa e altera a Resolução CONAMA no 357/2005, esta analisada em nosso estudo.

A necessidade de monitorar e analisar o uso da terra de uma bacia hidrografia, parte da concepção de que todas as atividades impactam os cursos d' água e, por conseguinte, a qualidade da água e a disponibilidade hídrica da bacia hidrográfica. As práticas agrícolas e pecuárias, cada vez mais recursos hídricos, causando principalmente erosão nas margens e o assoreamento dos cursos d' água (RIBEIRO e PARTENIANI,2008). 
Um aspecto importante na avaliação da qualidade da água de um corpo hídrico é acompanhar a sua tendência de evolução no tempo, possibilitando, dessa forma, a identificação de medidas preventivas, bem como, a eficiência de algumas medidas adotadas. Essa avaliação será possível, através da implantação de programas sistemáticos de monitoramento. Isso resultará, em séries históricas, que futuramente poderão ser analisadas a fim de estabelecerem padrões de distribuição sazonais e espaciais para indicadores bióticos e abióticos (PRAD0,2004).

Este trabalho objetiva avaliar a qualidade da água do Açude da Marcela, localizado na Sub-Bacia Hidrográfica do Rio Jacarecica, no município de Itabaiana no Estado de Sergipe, através de parâmetros físicos, químicos e biológicos, coletados entre junho de 2012 e março de 2013. Dados esses disponibilizados no site da Administração Estadual do Meio Ambiente do Estado de Sergipe (ADEMA) que funcionam como indicadores dos potenciais riscos do uso deste recurso para usuários.

\section{MATERIAL E MÉTODOS}

\section{1 ÁREA DE ESTUDO}

A área que compreende a sub-bacia hidrográfica do rio Jacarecica está localizada na região Agreste do Estado de Sergipe, composta por sete municípios, com áreas totais ou parcialmente, incluídas, como: Itabaiana, Areia Branca, Riachuelo, Santa Rosa de Lima, Malhador, Moita Bonita e Ribeiropólis, entre as coordenadas geográficas $10^{\circ} 44^{\prime}$ Sul e $37^{\circ} 20^{\prime}$ Oeste, afluente da bacia do rio Sergipe pela margem direita e possui uma área de aproximadamente $504 \mathrm{~km}^{2}$. Tendo as barragens Jacarecica I e II e o Açude da Marcela como importantes reservatórios de água para a irrigação de hortaliças, consumo humano, entre outros usos (DEHIDRO, 2004).

O reservatório da Marcela está localizado no município de Itabaiana no Estado de Sergipe e foi construído no período entre 1953 e 1957 pelo Departamento Nacional de Obras Contra Seca (DNOCS), com o barramento do riacho Fuzil, tendo como objetivo a manutenção do homem no campo. A capacidade de armazenamento é de $2.710 .000 \mathrm{~m}^{3}$ de água, ocupando uma área de $14 \mathrm{~km}^{2} \mathrm{com}$ fornecimento de água para irrigação em 156 hectares (DEHIDRO, 2004). Figura1.

Figura 1 - Vista Parcial do Açude da Marcela - SE.

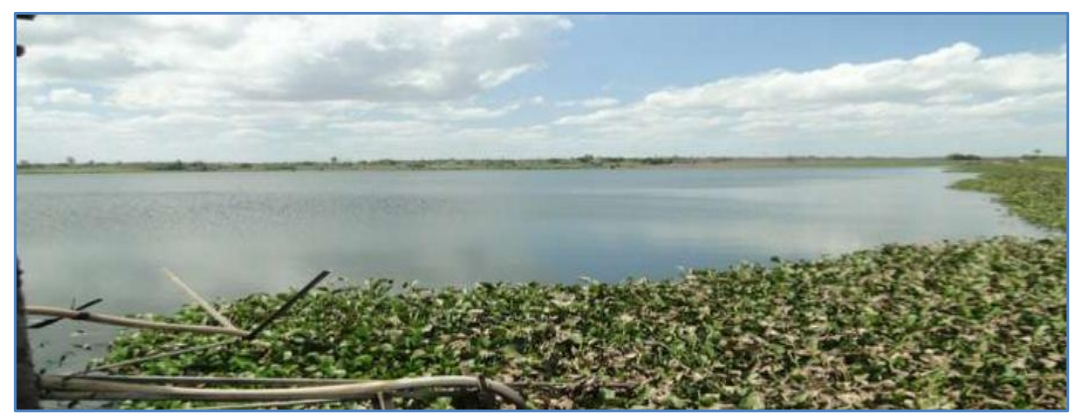

Fonte: Luis Carlos Sousa Silva - DESO, 2012.

O clima da região, de acordo com a classificação Köeppen é do tipo AS' clima tropical chuvoso, com temperatura média anual no mês mais quente (janeiro) de $26,2{ }^{\circ} \mathrm{C}$ e no mês mais frio (julho) de $22,5 \stackrel{\circ}{\circ} \mathrm{C}$. A precipitação pluviométrica média anual é de $886 \mathrm{~mm} /$ ano (DEHIDRO, 2004).

A geologia da sub-bacia do rio Jacarecica constitui-se de três unidades tectonoestratigráficas bem caracterizadas: o embasamento gnássio, a baixa de Dobramentos sergipanos e a bacia sedimentar Sergipe/Alagoas (FONTES e CORREIA, 2006). Os solos de maior importância, do ponto de vista espacial na Sub-Bacia são: planossolo nátrico e o argissolo vermelho-amarelo. Secundariamente ocorrem os neossolos litólicos, quartzarênicos e flúvicos (FONTES, 2003).

O planossolo nátrico na sub-bacia é derivado, predominantemente, dosaprolito do ganisse, em relevo plano (0 a 3\%), que corresponde à superfície depediplanação, de relevo suave ondulado. Atualmente, esse solo é muitoutilizado com a oleiricultura, principalmente no município de Itabaiana. Ébastante suscetível a erosão e as condições físicas do horizonte Bt são poucofavoráveis ao desenvolvimento do sistema radicular das plantas (FONTES, 2003). 
0 argissolo vermelho-amarelo eutrófico é de relevante potencial agrícola em decorrência de sua moderada ou baixa acidez, soma de bases trocáveis normalmente, média a alta e boa reserva de minerais primários facilmente disponíveis (FONTES, 2003).

A vegetação característica da sub-bacia, de acordo com o Atlas de Sergipe, pertence à formação denominada Floresta Mesófila Decídua (SEMARH/SHR, 2004). A acidez é alta e o seu uso para fins agrícolas exige a utilização de fertilizantes. A textura arenosa aumenta o risco da erosão principalmente quando o terreno é ondulado (SANTOS e ANDRADE, 1998).

\subsection{AMOSTRAGEM E ANÁLISES}

A qualidade da água de um determinado recurso hídrico é avaliada dependendo das substâncias presentes, denominada de parâmetros de qualidade da água. Tais substâncias caracterizam as condições em que a água se encontra para os mais variados usos, inclusive para sua preservação no meio ambiente.

A qualidade das águas superficiais depende do clima, da litologia da influência do homem. A ação antropogênica sobre recurso hídrico é talvez a responsável pelas maiores alterações da composição da água. Porto et al. (1991), consideram que as alterações da qualidade da água representam uma das maiores evidências do impacto das atividades humanas sobre abiosfera.

As diretrizes para a avaliação da qualidade das águas brasileiras foram estabelecidas pelo Conselho Nacional do Meio Ambiente, através da Resolução no 357/2005 do CONAMA. Esta resolução dividiu as águas do território brasileiro em três grandes categorias: águas doces, salobras e salinas. Em função dos usos preponderantes destas categorias foram estabelecidas nove classes, sendo cinco destas destinadas para águas doces (Classe especial, Classe 1, Classe 2, Classe 3 e Classe 4), duas para águas salobras (Classes 5 e 6) e duas para águas salinas (Classes 7 e 8). Cada classe é avaliada por parâmetros de qualidade e indicadores específicos, de modo a assegurar a qualidade necessária para seus usospreponderantes.

Foram levantadas no site da Administração Estadual do Meio Ambiente - (ADEMA) informações de coletas realizadas por este órgão para monitorar a qualidade da água, em determinados pontos, no Açude da Marcela na sub-bacia do rio Jacarecica - SE. Estas informações contemplam dados de identificação dos pontos de coletas, coordenadas geográficas, variáveis qualitativas da água. As variáveis físicas, químicas e biológicas foram analisadas, de acordo com a Resolução CONAMA n 357/05.

O monitoramento foi realizado pela Administração Estadual do Meio Ambiente do Estado de Sergipe, entre os meses de junho/2012 a março/2013. Estas amostras foram coletadas em três pontos distribuídos ao longo do Açude da Marcela, no município de Itabaiana no Estado de Sergipe.

O ponto 1 apresenta coordenadas geográficas em UTM, 24L 672849 e 88197 09, este situado no açude, a margem direita, nas imediações do Porto dos Barcos. 0 Ponto 2 está localizado nas imediações da Casa de Bombas,88 198 28. E o ponto 3 situado na margem esquerda do açude, em uma propriedade particular, com coordenadas geográficas em UTM, 24L 673525 e 8820211 . A Figura 2 apresenta a distribuição espacial dos pontos de coletas levantados na área de estudo na Sub-Bacia do Rio Jacarecica SE.

Figura 2 - Localização dos Pontos Coletados pela ADEMA no Açude da Marcela.

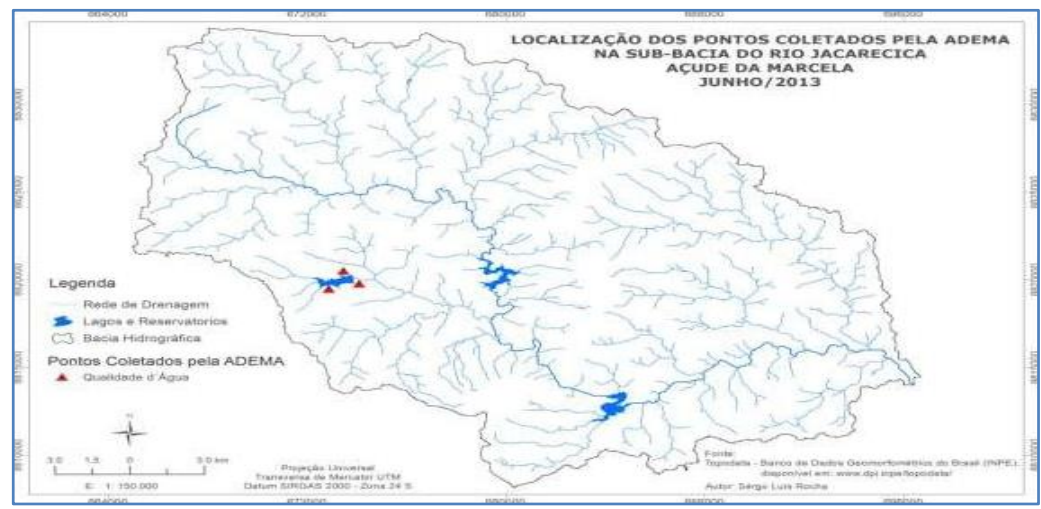

Fonte: Topodata - Banco de Dados Geomorfométrico do Brasil, 2013. 
Segundo os relatórios da Administração Estadual do Meio Ambiente do Estado de Sergipe, as amostras foram preservadas de acordo com o Guia de Coleta e Preservação de Amostras de Água da CETESB/1988 e os métodos analíticos utilizados foram do Standard Méthodos of Examination Water and Wosterwater, 2005.

As variáveis selecionadas para o estudo foram: Temperatura da Água, pH, Oxigênio Dissolvido (OD), Demanda Bioquímica de Oxigênio (DBO),A Figura 3 apresenta os dados de precipitação de chuva no município de Itabaiana no Estado de Sergipe no período de junho de 2012 a março de 2013, que foram cedidos pelo Centro de Análises e Previsão do Tempo e Clima da Secretária de Estado do Meio Ambiente e Recursos Hídricos - SE (SEMARH).

Figura 3 - Valores Mensais da Precipitação no Município de Itabaiana - SE.

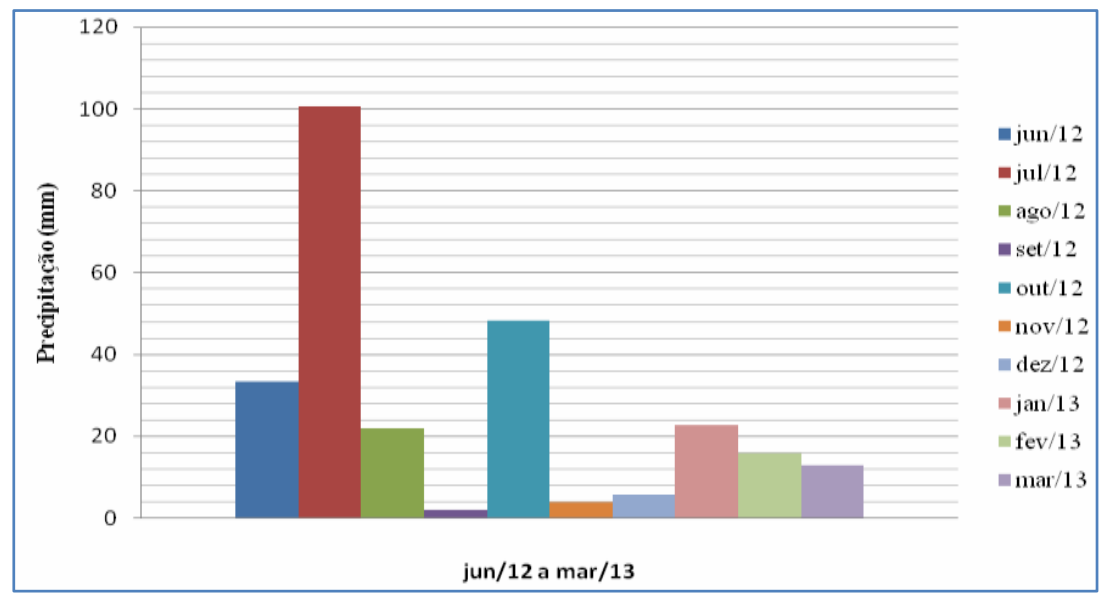

Fonte: Centro de Análises e Previsão do Tempo e Clima - SEMARH, 2013.

\section{RESULTADOS E DISCUSSÕES}

A análise exploratória realizada sobre os dados coletados pela ADEMA forneceu os resultados apresentados no Quadro 1. Pode-se observar que algumas variáveis não foram analisadas em todas as coletadas, por motivo de equipamento quebrado.

Segundo o Plano Estadual de Recursos Hídricos de Sergipe (2009) que estabelece diretrizes, metas, programas e projetos para a gestão dos recursos hídricos do Estado de Sergipe, que contempla o reenquadramento dos corpos d'água do Estado, classifica as águas do Açude da Marcela em Itabaiana, como água doce, classe 2. 
Quadro 1 - Variáveis de qualidade da água do Açude da Marcela no período de junho/2012 a março/2013.

\begin{tabular}{|c|c|c|c|c|c|c|c|c|}
\hline $\begin{array}{l}\text { Data da Coleta/ } \\
\text { Parâmetros }\end{array}$ & $\begin{array}{c}\text { Temperatur } \\
\text { a da água } \\
\left({ }^{\circ} \mathrm{C}\right)\end{array}$ & $\mathrm{pH}$ & $\begin{array}{c}\text { OD } \\
(\mathrm{mg} / \mathrm{L})\end{array}$ & $\begin{array}{c}\text { DBO } \\
(\mathrm{mg} / \mathrm{L})\end{array}$ & $\begin{array}{c}\text { Nitrogênio } \\
\text { Amonia cal } \\
\text { (mg/L) }\end{array}$ & $\begin{array}{l}\text { Salinidade } \\
\text { (mg/L) }\end{array}$ & $\begin{array}{l}\text { Fósforo } \\
\text { (mg/L) }\end{array}$ & $\begin{array}{c}\text { Coliformes } \\
\text { Termotolera } \\
\text { ntes } \\
\text { (Ufc/100mL) }\end{array}$ \\
\hline 19/06/12-Ponto1 & 25,7 & 7,6 & 5,2 & 22,3 & 0,39 & 549 & 1,98 & 14000 \\
\hline 19/06/12-Ponto2 & 26,8 & 7,6 & 2,3 & 35,2 & 0,34 & 564 & 1,88 & 18000 \\
\hline 19/06/12-Ponto3 & 27,2 & 7,6 & 7,3 & 34,6 & 0,28 & 557 & 1,94 & 6000 \\
\hline 04/07/12-Ponto1 & 26 & 7,7 & 5,3 & 71,7 & 0,02 & 526 & 1,8 & 37000 \\
\hline 04/07/12-Ponto2 & 26 & 7,7 & 4 & 63,6 & $* *$ & 528 & 2,08 & 2000 \\
\hline 04/07/12-Ponto3 & 26 & 7,7 & 5,4 & 53,1 & $* *$ & 529 & 2,24 & 6000 \\
\hline 02/08/12-Ponto1 & 26 & 8,2 & 11,3 & $*$ & 0,02 & 490 & 1,64 & 35100 \\
\hline 02/08/12-Ponto2 & 25 & 8,1 & 8,3 & $*$ & $* *$ & 497 & 1,71 & 2500 \\
\hline 02/08/12-Ponto3 & 25 & 8,2 & 10,1 & $*$ & $* *$ & 499 & 1,75 & 1300 \\
\hline 05/09/12-Ponto1 & 26,1 & 7,9 & 5,5 & 32,4 & 0,02 & 472 & 0,6 & 151000 \\
\hline 05/09/12-Ponto2 & 26,2 & 7,9 & 4,1 & 23,7 & $* *$ & 478 & 0,6 & 9000 \\
\hline 05/09/12-Ponto3 & 26,4 & 8 & 6,5 & 22,9 & $* *$ & 476 & 0,6 & 7000 \\
\hline 17/10/12-Ponto1 & 26,5 & 8 & 9,4 & $*$ & 0,01 & 449 & 1,64 & 5200 \\
\hline 17/10/12-Ponto2 & 26,5 & 7,9 & 4,9 & $*$ & 0,03 & 451 & 1,42 & 2900 \\
\hline 17/10/12-Ponto3 & 27 & 7,8 & 7 & $*$ & 0,01 & 453 & 1,51 & 900 \\
\hline 05/11/12-Ponto1 & 29 & 8,6 & 16,8 & 14,8 & $* *$ & 467 & 1,52 & 12200 \\
\hline 05/11/12-Ponto2 & 28 & 8,2 & 9,4 & 8,9 & 0,02 & 477 & 1,43 & 1500 \\
\hline 05/11/12-Ponto3 & 29 & 7,8 & 3,4 & 19,3 & 0,03 & 481 & 1,65 & 2600 \\
\hline 06/12/12-Ponto1 & 27,9 & 8,7 & 8,7 & 11,7 & 0,01 & 484 & 1,62 & 7800 \\
\hline 06/12/12-Ponto2 & 28 & 8,3 & 5 & 10 & 0,02 & 479 & 1,75 & 2400 \\
\hline 06/12/12-Ponto3 & 27 & 8,2 & 8,9 & 16,3 & 0,04 & 482 & 1,44 & 900 \\
\hline 03/01/13-Ponto1 & 26 & 8,5 & 4,1 & 12,7 & $* *$ & 499 & 1,62 & 14800 \\
\hline 03/01/13-Ponto2 & 27 & 8 & 1,6 & 10,5 & 0,02 & 500 & 1,62 & 3800 \\
\hline 03/01/13-Ponto3 & 27 & 8,3 & 4,9 & 14,6 & 0,01 & 492 & 1,67 & 1600 \\
\hline 06/02/13-Ponto1 & 27 & 8,2 & 7,9 & $*$ & 0,02 & 513 & 2,04 & 27700 \\
\hline 06/02/13-Ponto2 & 27 & 8,3 & 5,3 & $*$ & 0,01 & 517 & 2,04 & 18800 \\
\hline 06/02/13-Ponto3 & 28 & 8,8 & 12,8 & $*$ & $* *$ & 512 & 1,76 & 2200 \\
\hline 05/03/13-Ponto1 & 27 & 8,9 & 10,7 & 14,8 & 0,07 & 533 & 1,94 & 12100 \\
\hline 05/03/13-Ponto2 & 28 & 8,5 & 6,4 & 33,3 & 0,06 & 542 & 1,77 & 500 \\
\hline 05/03/13-Ponto3 & 28 & 8,9 & 5,7 & 24,6 & 0,05 & 539 & 1,81 & 1800 \\
\hline CONAMA 357/05 & & 6 a9 & $\geq 5,00$ & $\leq 5,00$ & 0,5 a 3,7 & $\leq 500$ & $\leq 0,05$ & $\leq 1000$ \\
\hline
\end{tabular}




\subsection{PARÂMETROS ANALISADOS}

\subsubsection{TEMPERATURA DA ÁGUA}

A temperatura da água é ditada pela radiação solar, condução e convecção ou pelos despejos industriais, esgotos e etc. Esta exerce influência nas atividades biológicas e no crescimento das espécies (VON SPERLING,1996).

As coletas foram realizadas no período da manhã entre $10 \mathrm{~h}$ e $12 \mathrm{~h}$, por funcionários da ADEMA - SE. As maiores temperaturas nas águas do Açude da Marcela ocorreram no mês de novembro/2012, com a máxima atingindo os $29^{\circ} \mathrm{C}$ nos pontos 1 e 3 e a mínima, $25^{\circ} \mathrm{C}$, verificada nos pontos 2 e 3 , no mês de agosto/2012, como pode ser observado nas Figuras 4, 5 e 6.

Figura 4 - Valores para a Temperatura da Água no ponto 1 coletados no Açude da Marcela

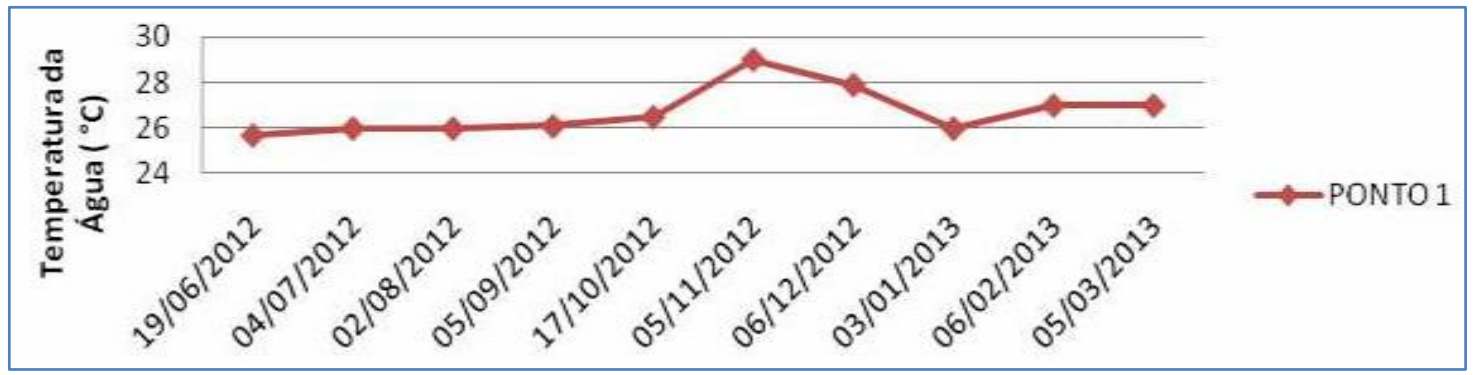

Figura 5 - Valores para a Temperatura da Água no ponto 2 coletados no Açude da Marcela

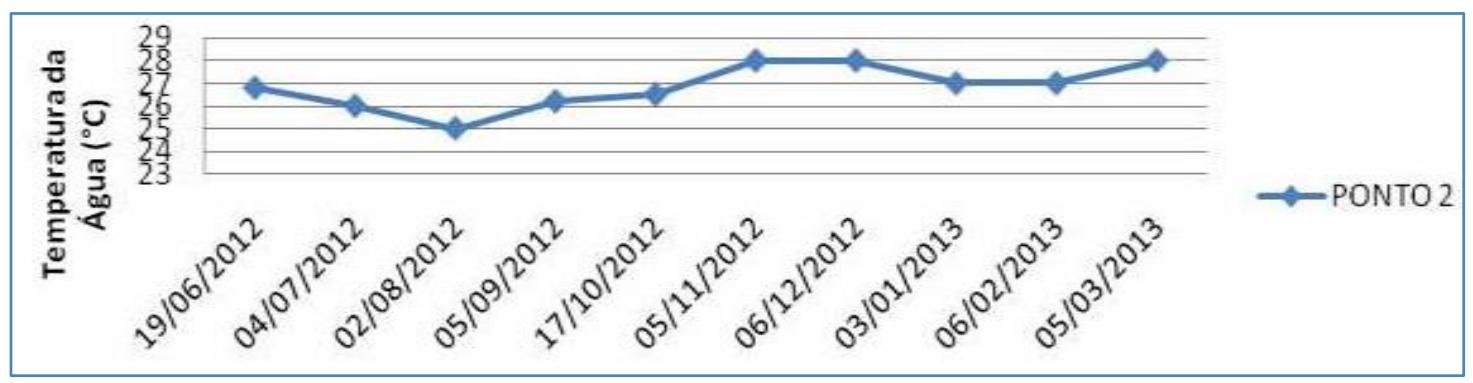

Figura 6 - Valores para a Temperatura da Água no ponto 3 coletados no Açude da Marcela

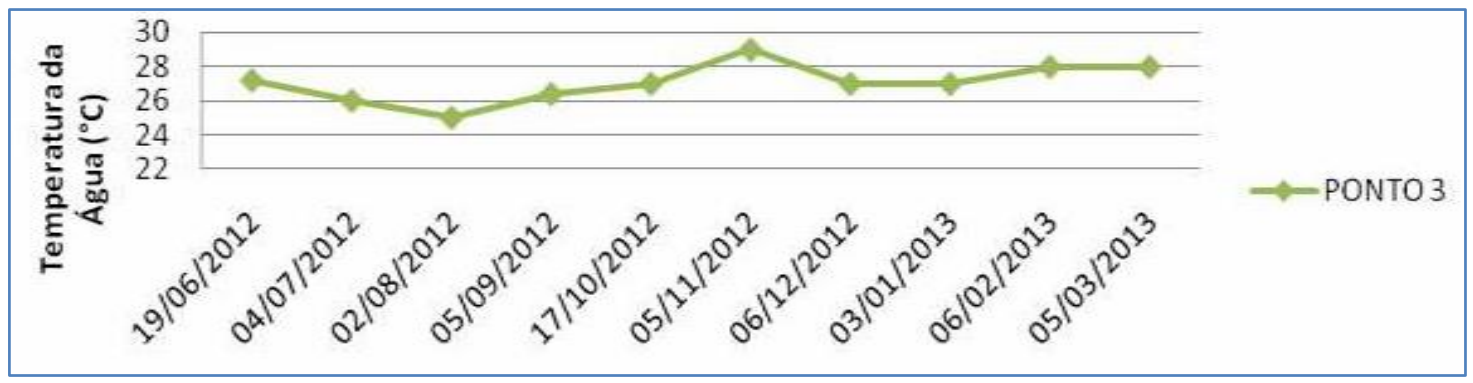

\subsubsection{POTENCIAL HIDROGENIÔNICO (PH)}

0 pH das águas é considerado um parâmetro fundamental para os ambientes aquáticos, mas a sua interpretação torna-se complexa devido ao grande números de fatores que podem influenciá-lo. No Açude da Marcela, o valor do pH variou entre 7,56 a 8,90, valores considerados entre os limites estabelecidos pela Resolução no 357/2005 do CONAMA, onde o pH pode variar entre 6 e 9, para águas doces, classe 2 (Figuras 7, 8 e 9) . 
Figura 7 - Valores para o pH no ponto 1 coletados no Açude da Marcela - SE.

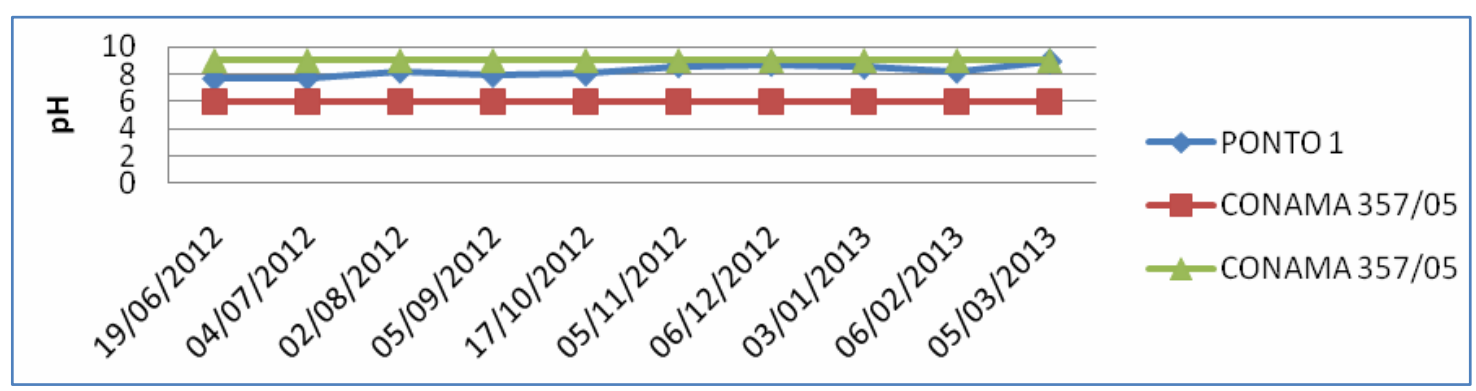

Figura 8 - Valores para o pH no ponto 2 coletados no Açude da Marcela - SE.

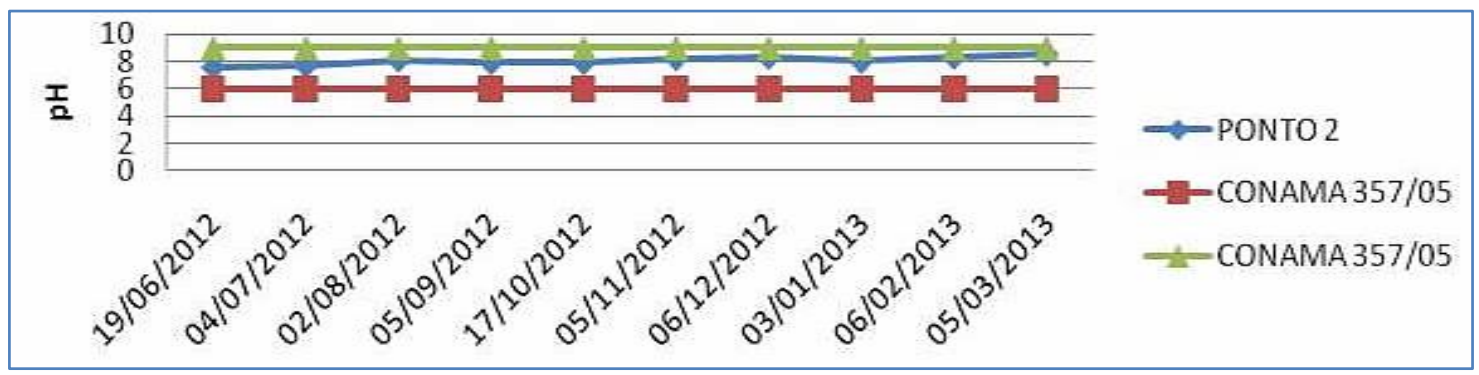

Figura 9 - Valores para o pH no ponto 3 coletados no Açude da Marcela - SE.

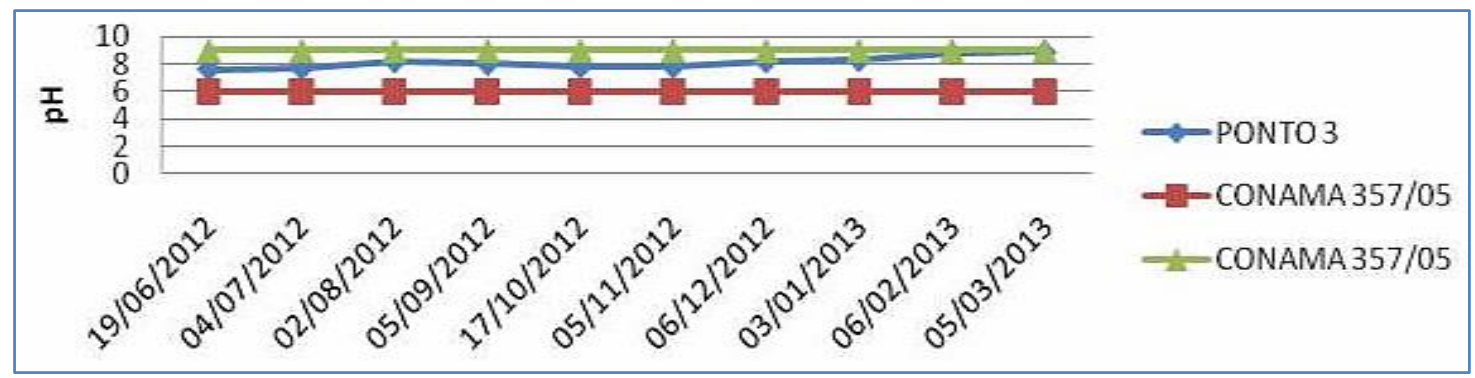

Mas, esse rápido aumento do pH ocasiona um acréscimo na concentração de amônia que é tóxica. E em condições de pH elevado, o ferro tende a tornar-se menos disponível para algumas plantas e a produção de toda comunidade aquática pode ser afetada. Em correntes e cursos d'água, o efeito mais significativo de valores extremos de pH é o provável efeito letal para peixes e outras vidas aquáticas (SPERLING, 2005).

Esse parâmetro pode interferir no processo de coagulação- precipitação química durante o tratamento da água, na corrosão de tubulações e equipamentos, no crescimento microbiano dos sistemas biológicos de tratamento, na toxidez de certos compostos e nos constituintes da alcalinidade e acidez da água (SPERLING,2005).

Barreto e Garcia (2010), observaram que os valores encontrados em todas as coletas realizadas por eles, nas águas do Açude do Buri, no município de Frei Paulo - SE, estavam dentro das normas da Resolução no 357/05 do CONAMA para águas doces de classe 1, que é de 6,0 a9,0.

Para Barbosa (2002), no caso do semiárido nordestino, cuja precipitação é menor que a evaporação, é comum encontrar valores de pH superiores a 8,0. Segundo Lima e Garcia (2008), os valores de $\mathrm{pH}$ encontrados, na água do Açude do Cajueiro no município de Ribeirópolis - SE, em todos os pontos estudados, apresentaram-se alcalinos, estando dentro dos limites estabelecidos para águas doce, classe 1 (entre 6,0 e 9,0) . 


\subsubsection{OXIGÊNIO DISSOLVIDO(OD)}

Nas Figuras 10, 11 e 12 observa-se a variação da concentração deoxigênio dissolvido na água do Açude da Marcela, durante o período estudado,ocorrendo algumas variações abaixo do estabelecido pela Resolução 375/05 doCONAMA, que determina valores acima de $5 \mathrm{mg} / \mathrm{L} \mathrm{02,} \mathrm{para} \mathrm{águas} \mathrm{doces,} \mathrm{classe} 2.0$ ponto 1 apresentou apenas um valor abaixo do determinado pelaResolução no 357/05 do CONAMA. 0 ponto 2 apresentou em quatro meses deanálises valores abaixo do determinado pela resolução, chegando a apresentarum valor de $1,6 \mathrm{mg} / \mathrm{L}$ de 02 , no mês de janeiro de 2013. Além disso, o ponto 2apresentou no mês de junho/12, um valor de $2,3 \mathrm{mg} / \mathrm{L}$ e nos meses de julho/12e setembro/12, valores de $4,0 \mathrm{mg} / \mathrm{L}$ e 4,1 mg/L, respectivamente. Esses valoresencontrados indicam problemas graves de disponibilidade de oxigênio no meioaquático, pois, podem comprometer a qualidade da vida aquáticaexistente nomeio. A baixa taxa de fotossíntese do fitoplâncton associada à redução datransparência, também, contribui para a redução da concentração de oxigêniodissolvido (LIBÂNIO, 2005). O ponto 3 apresentou apenas um valor abaixo do estabelecido pela resolução, este ocorrendo no mês de novembro/2012.

Figura 10 - Valores para o Oxigênio Dissolvido no ponto 1 coletados no Açude da Marcela

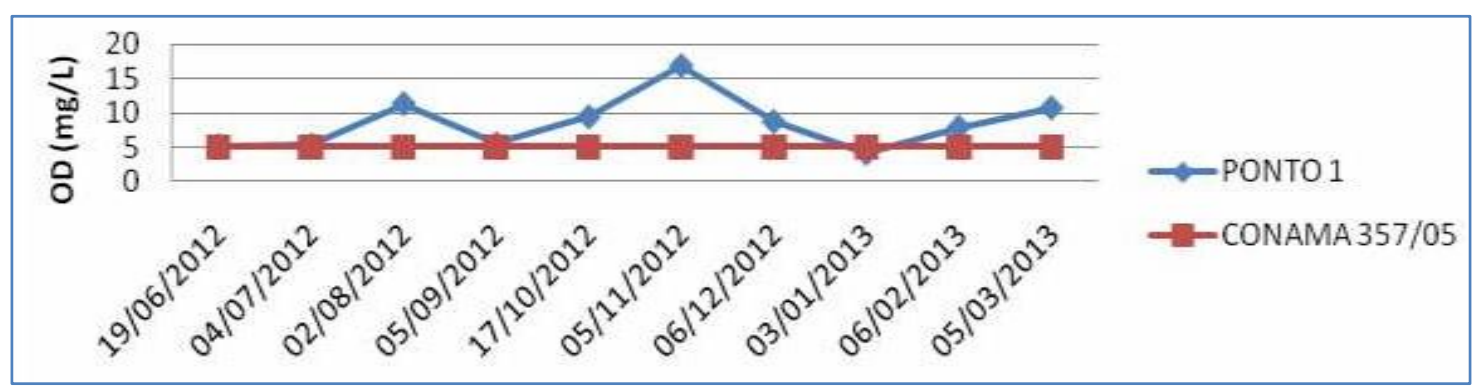

Figura 11 - Valores para o Oxigênio Dissolvido no ponto 2 coletados no Açude da Marcela

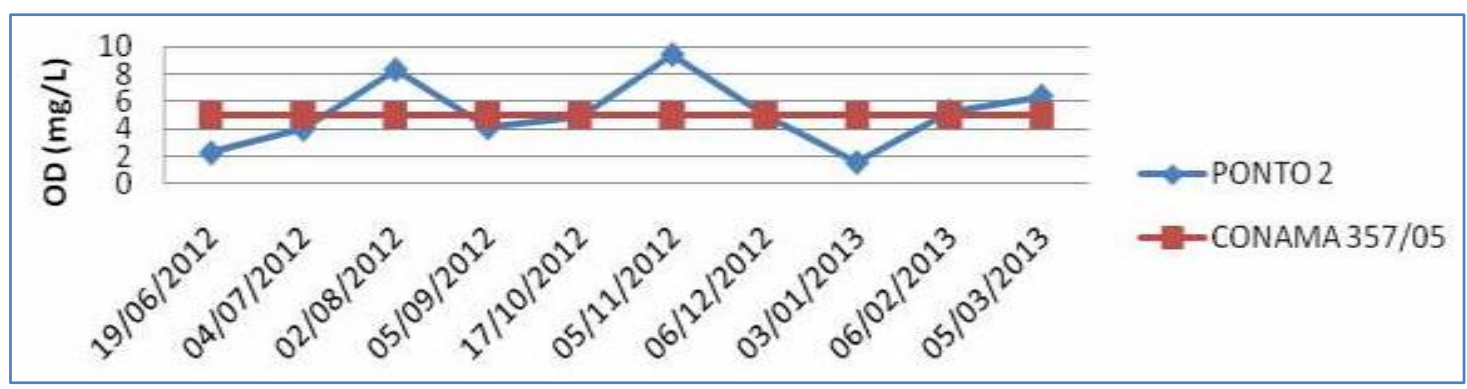

Figura 12 - Valores para o Oxigênio Dissolvido no ponto 3 coletados no Açude da Marcela

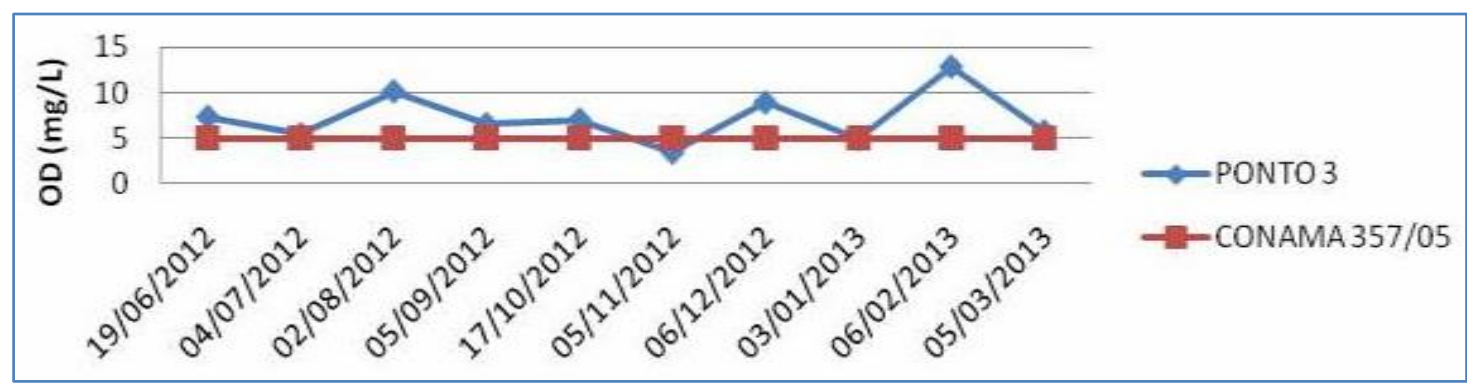

A quantidade de oxigênio dissolvido em águas naturais é muito variável, sendo dependente da temperatura, salinidade, turbulência da água e pressão atmosférica. Por outro lado, as flutuações diurnas e sazonais, ocasionadas pelas variações de temperatura, atividade fotossintética e descarga dos rios, também, influenciam na concentração de oxigênio dissolvido na água. Para os organismos aquáticos, são particularmente prejudiciais, as variações de oxigênio dissolvido, sendo a quantidade 
mínima do gás, que permite a manutenção dos processos metabólicos, variável, dependendo da espécie e dentro da espécie, para cada indivíduo. Em quantidades mínimas de oxigênio.

Segundo Lima e Garcia (2008), as concentrações de oxigênio dissolvido encontradas na água do Açude do Cajueiro no município de Ribeirópolis - SE, variaram entre $0,89 \mathrm{mg} / \mathrm{L}$ a $10,22 \mathrm{mg} / \mathrm{L}$. Para os autores, esses resultados demonstraram que a água do açude é classificada como água doce, classe 4 na época chuvosa e classe 3 na época seca. Sendo observado que existe uma homogeneidade nos valores de oxigênio dissolvido para os pontos de superfície e meio do açudeestudado.

Nas águas da barragem do João Ferreira, no município de Ribeirópolis SE analisadas também, por Lima e Garcia (2008), a classificação é para águas doces de classe 3, no período chuvoso e classe 1 no período seco. Entretanto, em determinado ponto da barragem, este apresentou elevados valores de oxigênio dissolvido, possivelmente, por ser um ponto onde ocorre maior movimentação do corpo d'água.

\subsubsection{DEMANDA BIOQUÍMICA DE OXIGÊNIO(DBO)}

A Demanda Bioquímica de Oxigênio é a quantidade de oxigênio necessária para oxidar a matéria orgânica por decomposição microbiana aeróbica para uma forma inorgânica estável. Considerada como a qualidade de oxigênio consumida durante um determinado período de tempo, numa temperatura de incubação específica $\left(5\right.$ dias a $\left.20^{\circ} \mathrm{C}\right)($ CETESB, 2012).

No caso da Demanda Bioquímica de Oxigênio (DBO) no Açude da Marcela, os valores determinados nas amostras estão muito acima do limite da Resolução em questão $(5 \mathrm{mg} / \mathrm{L}$ 02). Açude que aporta esgotamento doméstico e sanitário da água urbana da cidade de Itabaiana, contribuindo para a degradação da qualidade da água na bacia (Figuras 13, 14 e15).

Essa degradação pode ser explicada, já que os maiores aumentos em termos desse indicador em um corpo d'água são provocados por despejos de completa extinção do oxigênio na água, provocando o desaparecimento de peixes e outras formas de vida aquática. A baixa taxa de fotossíntese do fitoplâncton associado à redução da transparência, também, contribui para a redução da concentração de oxigênio dissolvido neste período (CETESB, 2012).

Figura 13 - Valores para a Demanda Bioquímica de Oxigênio no ponto 1 coletados no Açude da Marcela $-\mathrm{SE}$.

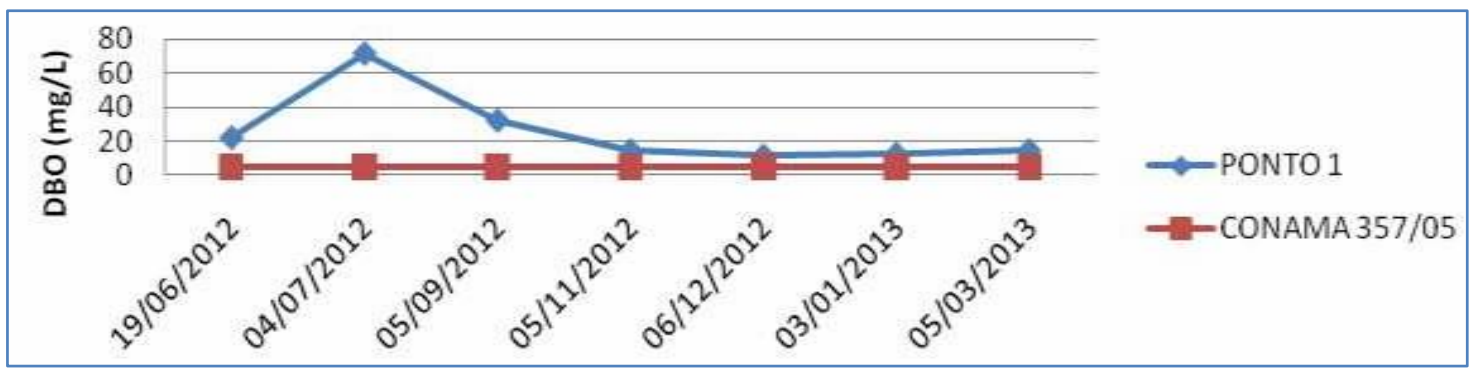

Figura 14 - Valores para a Demanda Bioquímica de Oxigênio no ponto 2 coletados no Açude da Marcela $-\mathrm{SE}$.

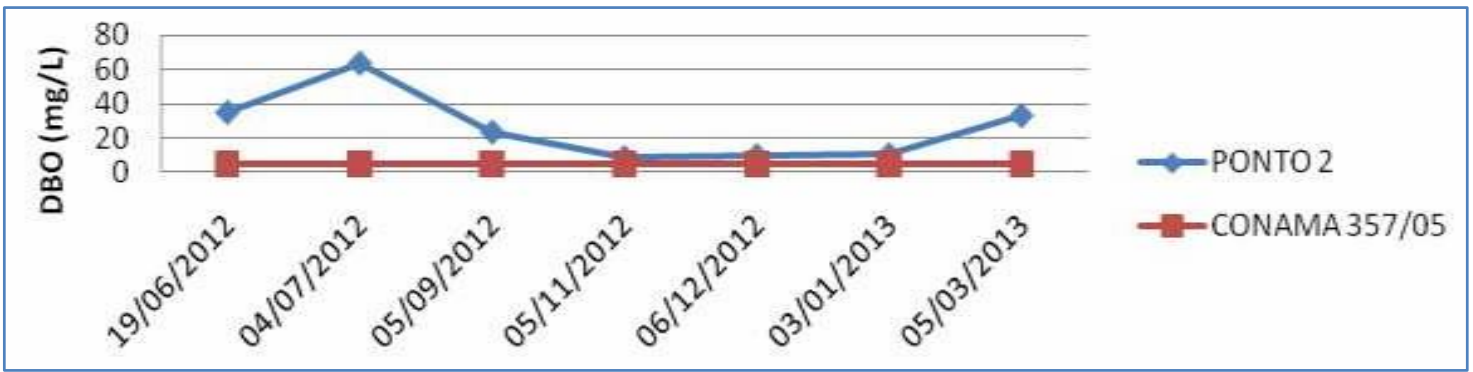


Figura 15 - Valores para a Demanda Bioquímica de Oxigênio no ponto 3 coletados no Açude da Marcela $-\mathrm{SE}$.

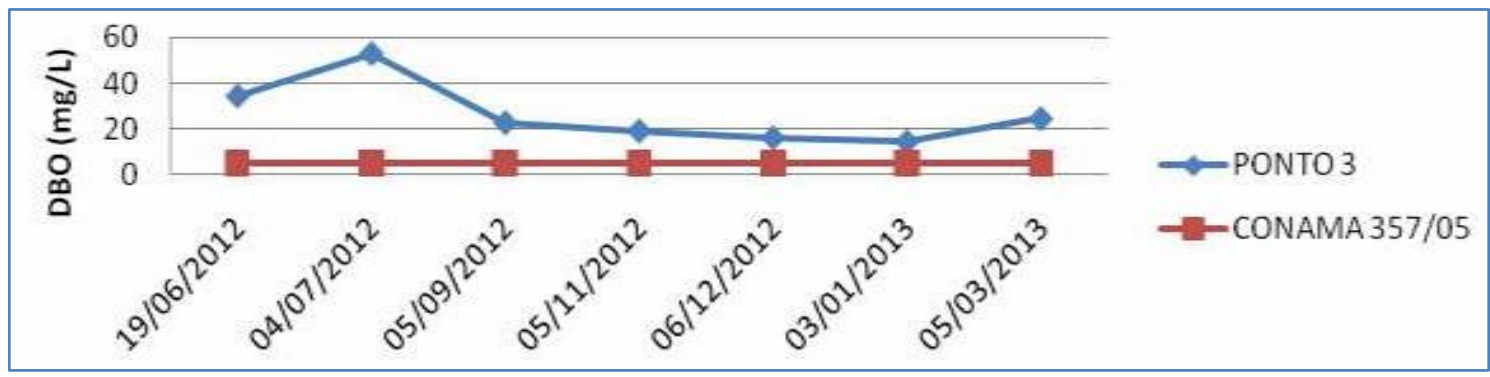

No caso do Açude da Marcela observou-se que os maiores valores de DBO foram identificados no mês de julho/2012, onde a precipitação neste mês atingiu 100,6 mm, podendo ser explicado pelo fato que os maiores aumentos do DBO são provocados por despejos de origem predominantemente orgânicos, estes carreados pela ação das águas pluviais para o leito do açude, interferindo na concentração de oxigênio dissolvido.

Ceretta (2004), avaliou os aspectos da qualidade da água na sub-bacia hidrográfica do Arroio Cadena, no município de Santa Maria - RS, observando que determinados pontos apresentaram valores acima do limite de $5 \mathrm{mg} / \mathrm{L}$ em todas as campanhas realizadas. Um ponto apresentou valores extremos de DBO, demonstrando uma grande quantidade de matéria orgânica presente. E um determinado ponto, em duas campanhas, apresentou os teores de matéria orgânica superiores ao limite de concentração para águas doces, classe 2.

\subsubsection{NITROGÊNIO AMONIACAL}

0 nitrogênio amoniacal esteve dentro da normalidade com a determinação da Resolução 357/05 do CONAMA para águas doce, classe 2, apresentando concentrações inferiores a 3,7 mg/L N, para pH $\leq 7,5$, $2,0 \mathrm{mg} / \mathrm{L} \mathrm{N}$, para 7,5 < pH $\leq 8,0,1,0 \mathrm{mg} / \mathrm{L} \mathrm{N}$, para $8<\mathrm{pH} \leq 8,5$ e 0,5 mg/L, para $\mathrm{pH}>8,5$, nas amostras no Açude da Marcela.

Em termos de valores, no ponto 1, o valor mínimo e máximo encontrado foi 0,01 mg/L $\mathrm{N}$ e 0,39 mg/L N, respectivamente. No ponto 2, o valor mínimo e máximo encontrado foi 0,01 $\mathrm{mg} / \mathrm{L} \mathrm{N}$ e 0,34 mg/L $\mathrm{N}$, respectivamente. Enquanto, que no ponto 3, o valor mínimo e máximo encontrado foi 0,01mg/L $\mathrm{N}$ e 0,28 mg/L N, respectivamente. (Figuras 16, 17 e 18). A ocorrência desses valores demonstra que o nitrogênio amoniacal não apresenta possíveis fontes podem evidenciar presença de poluição e a redução da eficácia no processo de desinfecção da água pelo uso do cloro (ALABURDA e NISHIHARA, 1998).

Vasco et al. (2010), com resultados encontrados em análise das águas que entram no estuário do Rio Vaza Barris nas imediações do município de Itaporanga d'Ajuda, SE, concluíram que a montante, não houve indícios de contaminação por nitrogênio nas suas diversas formas. Porém, a jusante foram detectados indícios de contaminação por nitrogênio nas formas de nitrito e nitrato com concentrações $0,02 \mathrm{mg} / \mathrm{L} \mathrm{N}$ e 0,15 mg/L N, respectivamente. Esses valores indicam uma contaminação remota por nutrientes.

Figura 16 - Valores para o Nitrogênio Amoniacal no ponto 1 coletados no Açude da Marcela - SE.

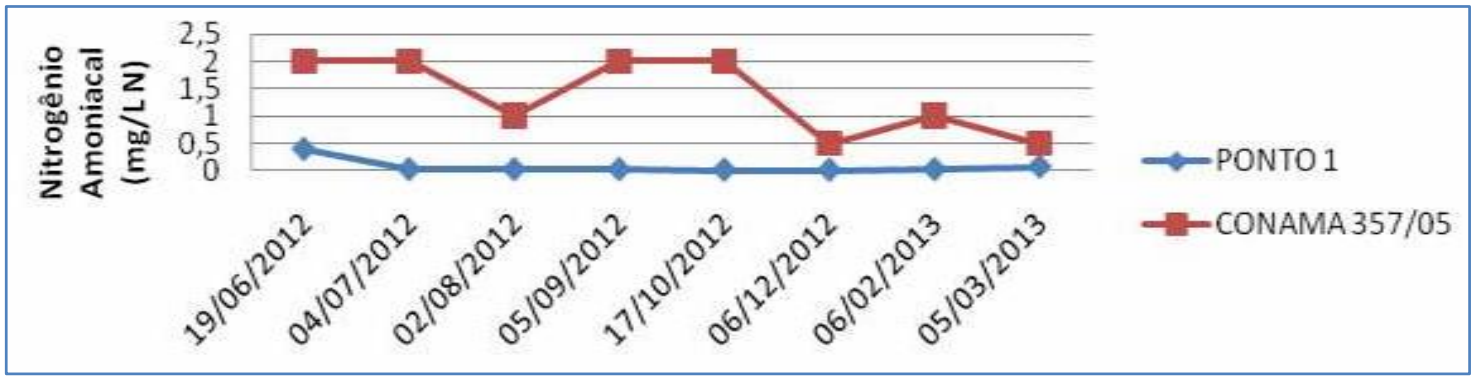


Figura 17 - Valores para o Nitrogênio Amoniacal no ponto 2 coletados no Açude da Marcela - SE.

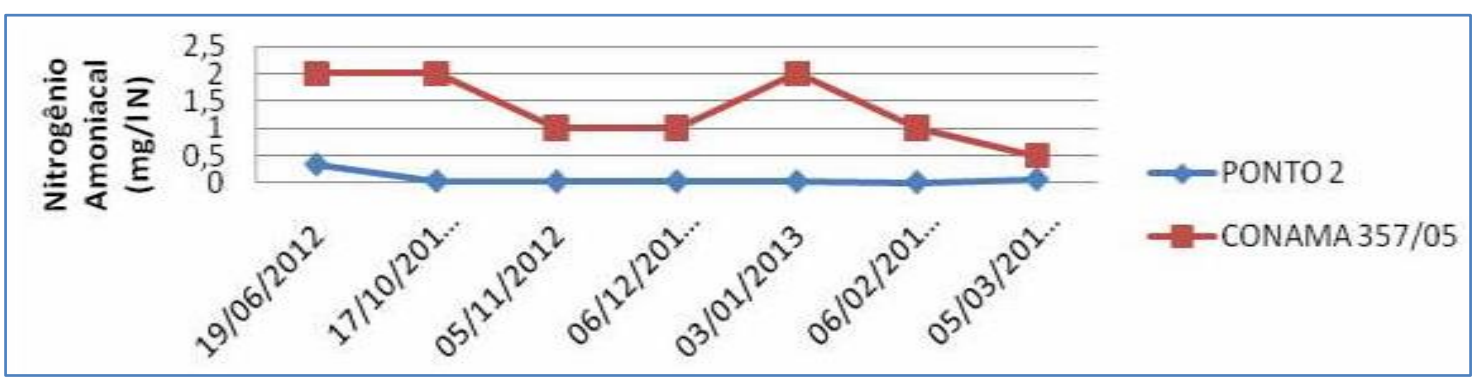

Figura 18 - Valores para o Nitrogênio Amoniacal no ponto 3 coletados no Açude da Marcela - SE.

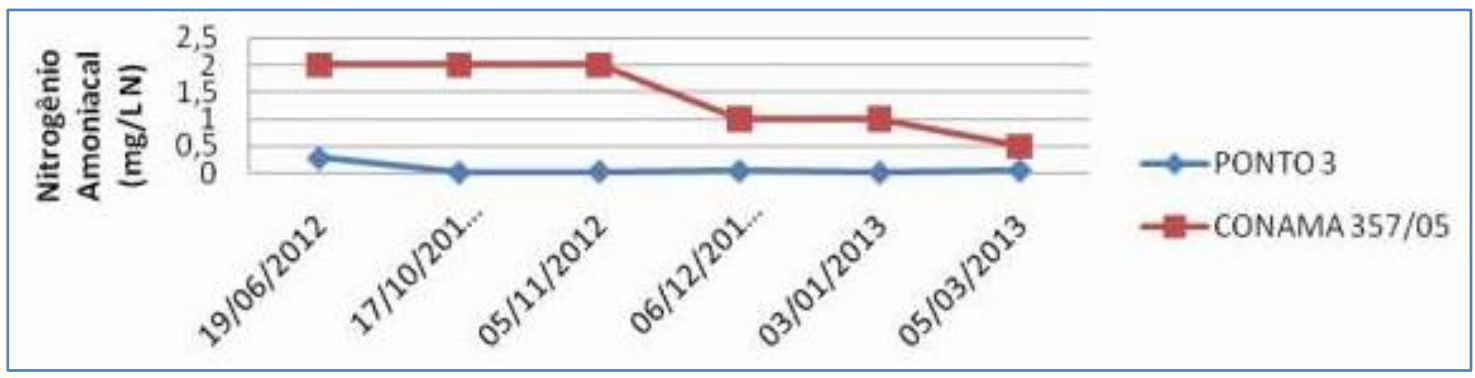

\subsubsection{SALINIDADE}

Comparando os valores dos parâmetros com o valor máximo permissível estabelecido pela Resolução noㅜ 357/05 do CONAMA de 500 mg/L, nota-se que a salinidade no Açude da Marcela variou de 449 mg/L no ponto 1 a $557 \mathrm{mg} / \mathrm{L}$ no ponto 3, (Figuras 19, 20 e 21).

Figura 19 - Valores para a Salinidade no ponto 1 coletados no Açude da Marcela - SE.

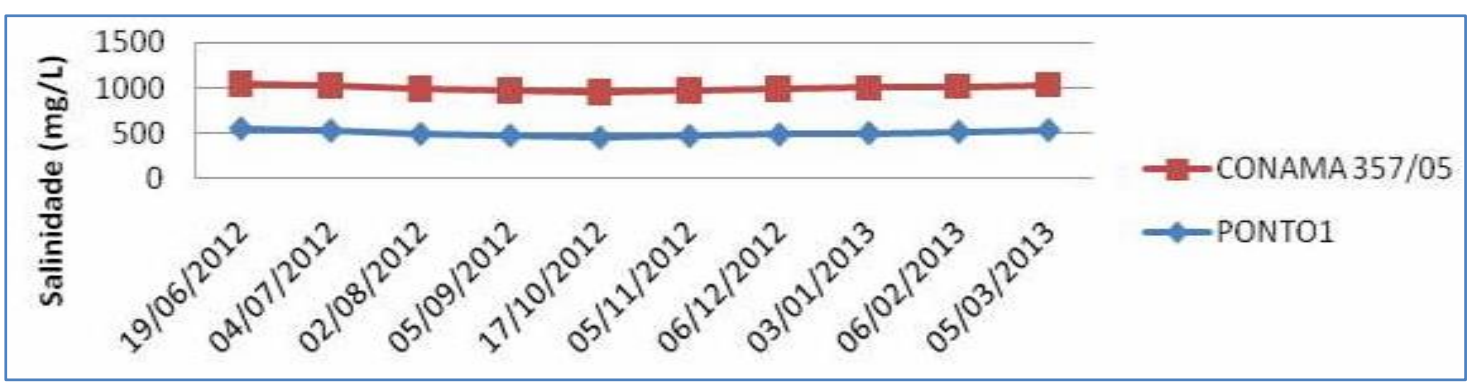

Figura 20 - Valores para a Salinidade no ponto 2 coletados no Açude da Marcela - SE.

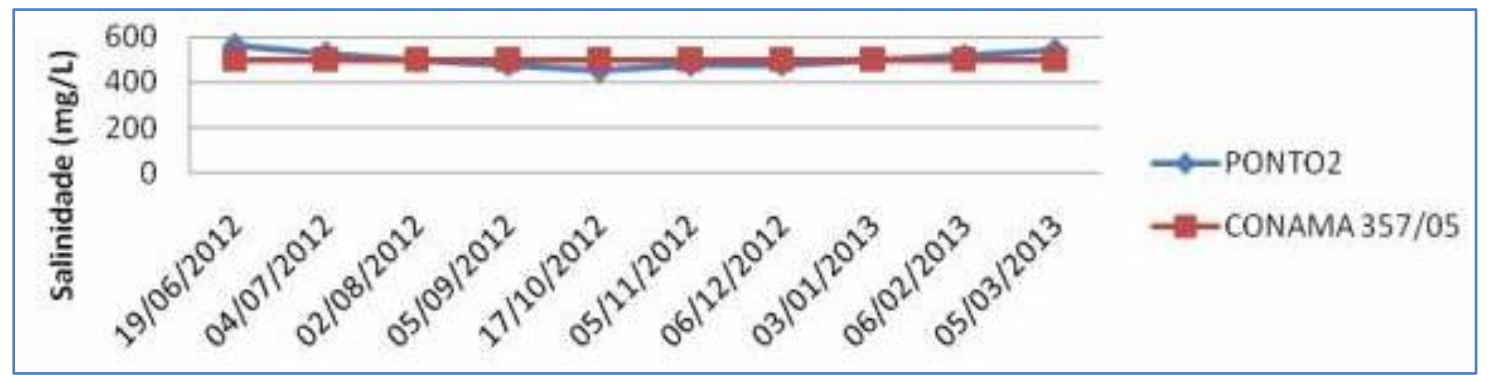


Figura 21 - Valores para a Salinidade no ponto 3 coletados no Açude da Marcela - SE.

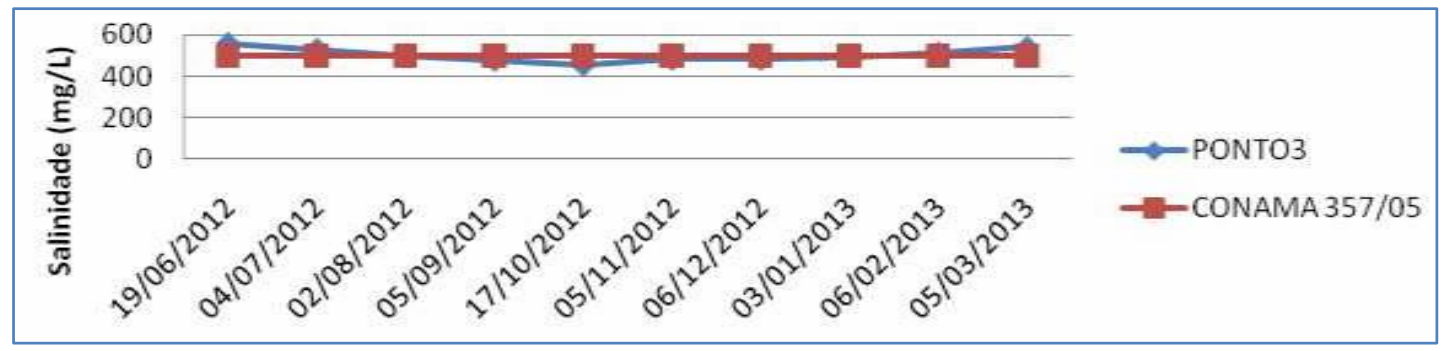

Segundo Von Sperling (1996), as principais contribuições antrópicas para o aumento da qualidade de sólidos na água dos mananciais são: o despejo de esgotos e o uso dos solos para a agricultura. Os esgotos domésticos não tratados podem contribuir com uma variação típica de 700 a $1350 \mathrm{mg} / \mathrm{L}$ de sólidos totais. Observando os dados coletados, quase todos os valores estão dentro do limite dos parâmetros da Resolução do CONAMA no 357/05 para água doce, classe 2.

Barreto e Garcia (2010), na análise da água do Açude Buri - Frei Paulo/SE, encontraram concentrações no período seco de 7,0 mg/L a 10,0 mg/L e no período chuvoso de 76,0 mg/L e 88,0 mg/L. Esses valores obtidos ficaram muito abaixodos estabelecidos pelaResolução CONAMA 357/05paraáguas doce, classe 1 e 2 , que é de $500 \mathrm{mg} / \mathrm{L}$.

\subsubsection{FÓSFORO TOTAL(P)}

0 fósforo é essencial para o crescimento de organismos e pode ser o nutriente que limita a produtividade primária de um corpo d'água. No Açude da Marcela, $100 \%$ dos valores das amostras que variaram de 0,60 a 2,24 mg/L, estavam acima dos limites definidos pela Resolução no 357/2005 do CONAMA para a classe 2, água doce $(0,05 \mathrm{mg} / \mathrm{L})$ (Figuras 22, 23 e 24).

Considerado limitante da produtividade primária dos ecossistemas aquáticos, o fósforo é apontado como principal responsável pela eutrofização artificial desses sistemas. Todo fósforo presente em águas naturais pode ter origem das rochas da bacia de drenagem, do material particulado na atmosfera, além de fontes artificiais, como esgoto e deflúvio superficial agrícola que carreiam compostos químicos e fertilizantes.

No Açude em estudo, os maiores valores de fósforo foram apresentados nos meses de junho e julho de 2012, podendo ser explicado pela pluviosidade ocorrida nestes meses $(33,6 \mathrm{~mm}$ e $100,6 \mathrm{~mm}$, respectivamente), pois essas concentrações possivelmente foram influenciadas pelo uso de fertilizantes aplicados na agricultura, geralmente nos meses de plantio, que nessa região ocorre no período chuvoso e por ação das águas pluviais que carreiam para o leito do açude compostos que interferem essa concentração.

Figura 22 - Valores para o Fósforo Total no ponto 1 coletados no Açude da Marcela - SE.

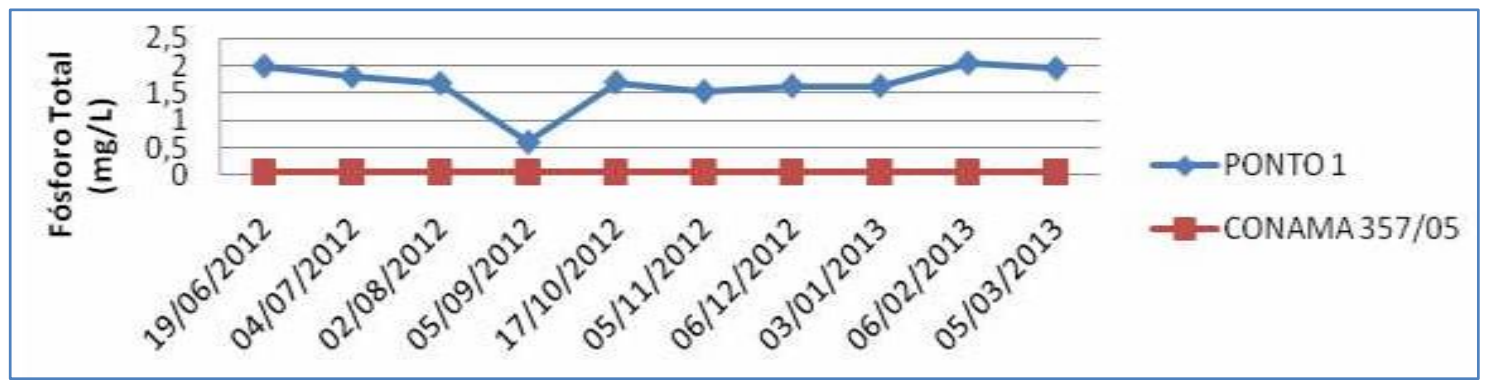


Figura 23 - Valores para o Fósforo Total no ponto 2 coletados no Açude da Marcela - SE.

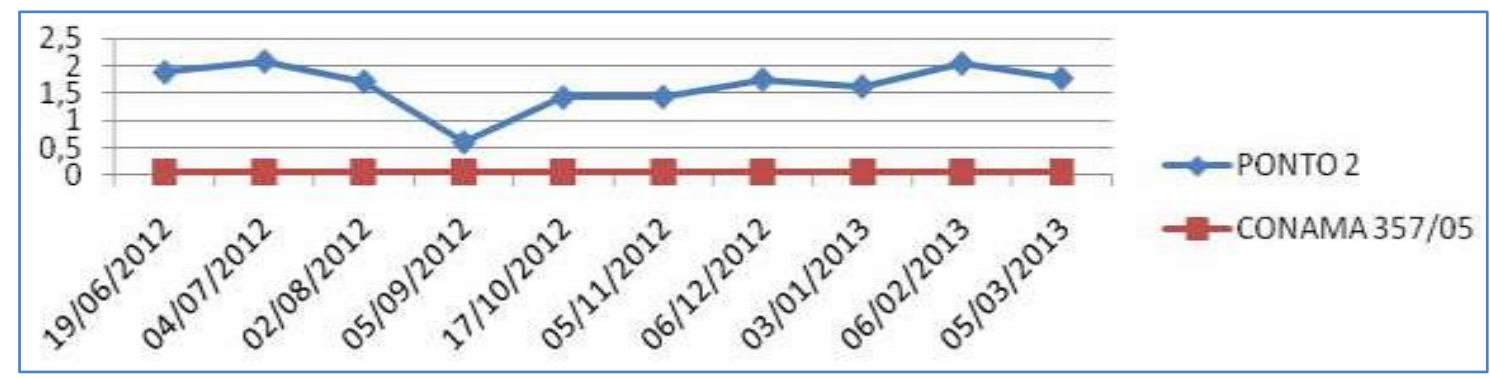

Figura 24 - Valores para o Fósforo Total no ponto 3 coletados no Açude da Marcela - SE.

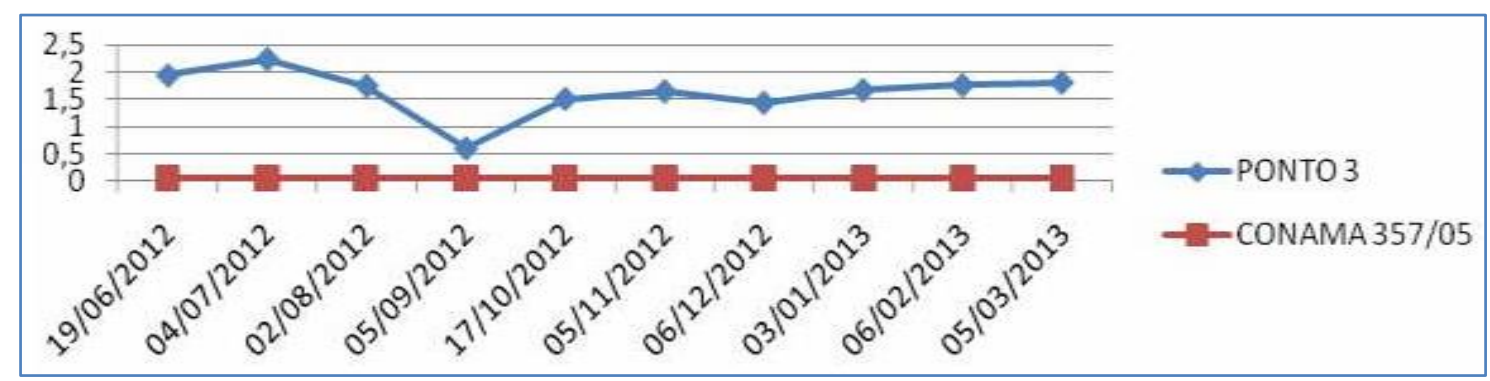

Segundo Netto et al. (2011), as concentrações de fósforo total, encontradas na avaliação da qualidade da água do córrego Terra Branca no município de Uberlândia - MG, apresentaram valores que ultrapassaram o determinado pela Resolução CONAMA 357/05 (0,050 mg/L), para ambiente lótico, que é o caso do córrego estudado. Essas altas concentrações evidenciam que os compostos aplicados permanecem na estrutura do solo por longos períodos.

\subsubsection{COLIFORMES TERMOTOLERANTES}

Com relação aos coliformes termotolerantes, somente três amostras analisadas no Açude da Marcela apresentaram valores inferiores ao limite de $1000 \mathrm{NMP} / 100 \mathrm{~mL}$. Sendo que a maioria apresentou valores superiores ao limite em comparação aos parâmetros definidos para água doce, classe 2, de acordo com a Resolução no 357/2005 do CONAMA (Figuras 25, 26 e 27). Vários fatores podem ter contribuído para essa baixa qualidade da água, como atividades antrópicas diversas relacionadas ao lançamento de efluentes domésticos e agropastoris e depósitos de lixo.

O dado coletado no ponto 1 no dia 05/09/2012 apresenta uma discrepância em relação aos demais dados, mas foi avaliado como um valor acima do valor limite da Resolução no 357/05 do CONAMA, para águas doces, classe 2 .

Silva (2006), analisou a qualidade da água na Barragem Jacarecica I em Itabaiana - Sergipe. No seu estudo, nenhuma das amostras analisadas excedeu o limite de 200 coliformes termotolerantes, considerado limite da classe 1 de águas doces, de acordo com a Resolução no 357/05 do CONAMA. Concluindo que, a água é adequada para a irrigação das culturas a que se destina nos agroecossistemas daregião.

Vasco et al. (2010), nos resultados encontrados na análise da água que entra no estuário do rio Vaza Barris nas imediações do município de Itaporanga d'Ajuda, SE, concluíram que a montante, o valor para coliformes termotolerantes de $400 \mathrm{NMP} / 100 \mathrm{~mL}$, esteve abaixo do seu valor de referência pela legislação (1000NMP/100mL), porém, seu uso estava comprometido para irrigação, cujo limite define valores abaixo de $200 \mathrm{NMP} / 100 \mathrm{~mL}$. A água coletada à montante ultrapassou em duas vezes esse limite e a água analisada à jusante ultrapassou em dezessetevezes.

Considerando o limite de 1000NMP/100 mL, para as demais finalidades de uso da água do rio, Vasco et al. (2010), concluíram que, somente, a água tomada a jusante do perímetro urbano estaria desqualificada, pois ultrapassou em 3,4 vezes o limite da Resolução CONAMA no 357/05 e que vários fatores podem ter contribuído para essa baixa qualidade da água. 
Figura 25 - Valores para os Coliformes Termotolerantes no ponto 1 coletados no Açude da Marcela - SE.

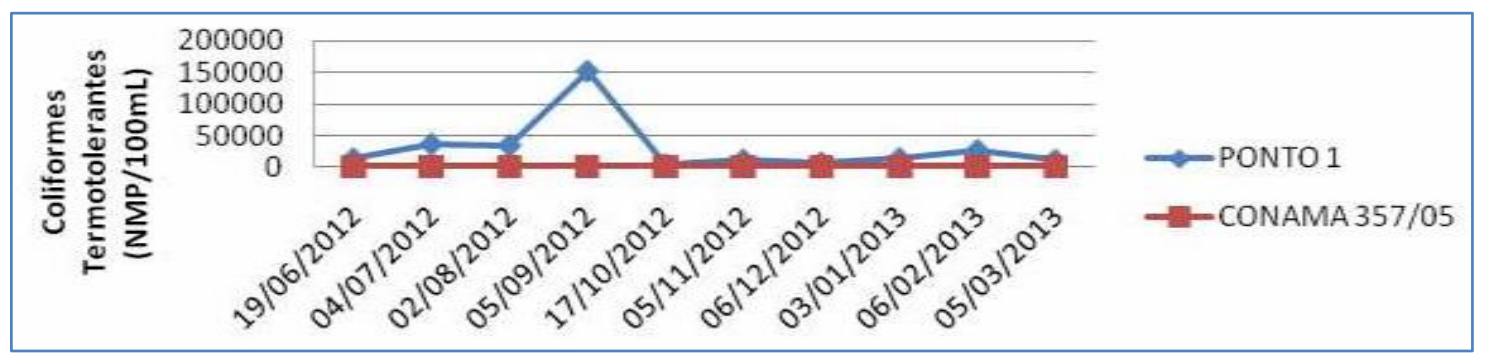

Figura 26 - Valores para os Coliformes Termotolerantes no ponto 2 coletados no Açude da Marcela - SE.

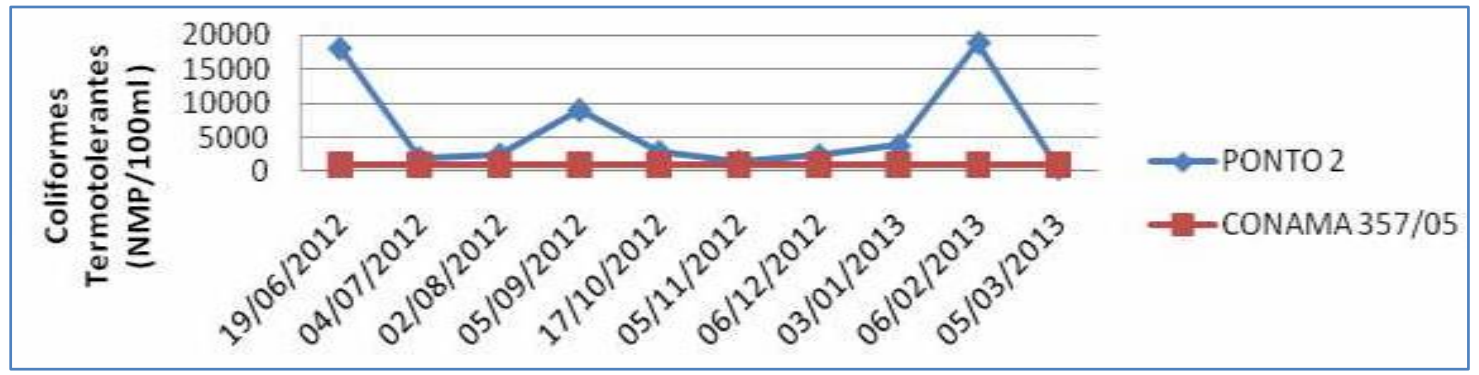

Figura 27 - Valores paraos Coliformes Termotolerantes no ponto 3 coletados no Açude da Marcela - SE.

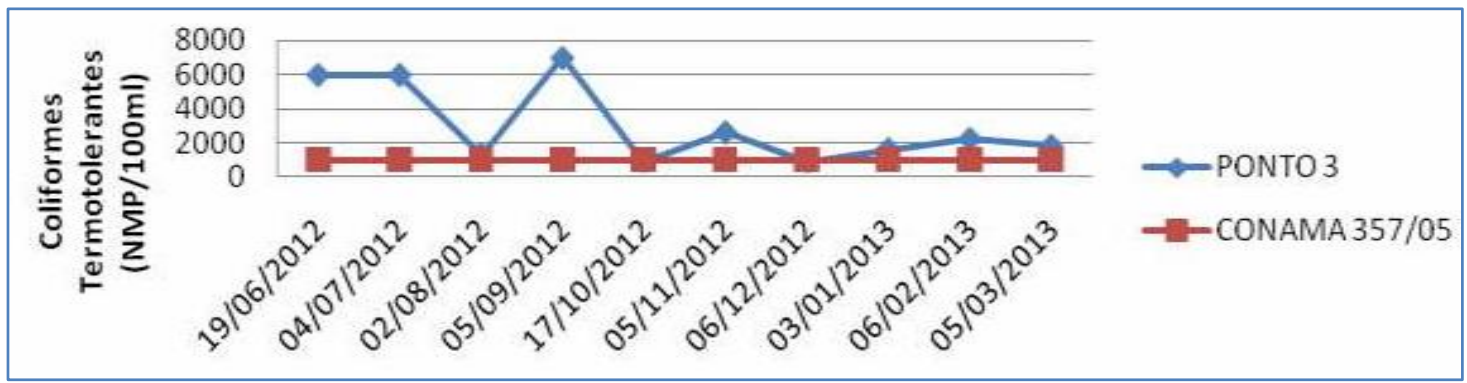

\section{CONCLUSÕES}

A qualidade da água do Açude da Marcela, de acordo com os resultados dos parâmetros físicos, químicos e biológicos obtidos no presente estudo, apresenta limitação para o seu uso, uma vez que foram detectados problemas nos parâmetros: a Demanda Bioquímica de Oxigênio (DBO), o Fósforo Total e os Coliformes Termotolerantes. Estes, em desacordo com os limites estabelecidos na Resolução noㅜ 357/2005 do CONAMA, para águas doces, classe2.

Os resultados observados evidenciam que os altos índices de coliformes termotolerantes encontrados demonstram problemas de saneamento no açude em questão. Verifica-se através das análises da água realizadas, que os coliformes termotolerantes foram os maiores responsáveis pela deterioração da qualidade da água.

Segundo os resultados apresentados, frente às características de uso e ocupação do solo na área em estudo, é possível associar as principais fontes de aporte de poluentes nos corpos hídricos. O Açude da Marcela apresenta uma característica de ocupação rural, utilizando agrotóxicos nas plantações, e o despejo do esgotamento doméstico e sanitário da área urbana da cidade de Itabaiana, considerado um grande contribuinte na mudança da qualidade da água, com o aumento da carga orgânica e microbiológica.

A ausência de esgotamento sanitário em parte deste setor e a atitude de parcela da população, nos aspectos relativos aos resíduos sólidos (acondicionamento não adequado) e a própria disposição nas margens, são as principais causas da degradação da qualidade da água observada. A dinâmica de uso e a ocupação do solo de forma desordenada em áreas urbanas e rurais da sub-bacia hidrográfica do rio Jacarecica contribuem substancialmente para a degradação da qualidade da água, e o fator determinante deve-se às cargas poluidoras (difusas e pontuais) de origem doméstica. 
É recomendável que o Conselho de Recursos Hídricos do Estado proponha ações preventivas para a melhoria das condições sanitárias da bacia, principalmente nas imediações dos perímetros urbanos. Neste aspecto, é necessário que as entidades ambientais, órgãos públicos e privados, e a sociedade, de modo geral, conscientizem-se para a recuperação e preservação dos recursos naturais, não somente na sub- bacia hidrografica em questão, como no seu entorno. Além disso, essa recuperação e prevenção podem ser realizadas através do tratamento adequado dos esgotos domésticos dos municípios da bacia, bem como, a adoção de novas tecnologias de manejo nas áreas agrícolas.

\section{REFERÊNCIAS}

[1] ALABURDA, J. e NiShiARA, L. Presença de Compostos de Nitrogênio em Águas de Poços. Revista de Saúde Pública, v.32, n. 2, São Paulo. p. 160-165. Disponível em: <http://www.scielosp. org/scielo.php>. Acesso em: 02 dez. 2012.

[2] APHA, 2005. Standard Methods for the Examination of water and Wastewater. 21a ed. United States of American Public Health Association, 2005.

[3] BARBOSA, J. E. L. Dinâmica do fitoplancton e condicionantes limnológicos nas escalas de tempo (nictimeral/sazonal) e de espaço (vertical/horizontal) no açude Taperoá II. Trópico semi-árido paraibano. 2002, 208f. Tese (Doutorado em Recursos Naturais) - Departamento de Ecologia e Recursos Naturais - Universidade Federal de São Carlos, São Carlos - SP.

[4] BARRETO, P. R. e GARCIA, C. A. B. Caracterização da qualidade da água do açude Buri - Frei Paulo/SE.Revista Scientia Plena.V. 6, n. 9 2010. Disponível em: <http://www.scientiaplena.org.br>. Acesso em: 07 jan. 2013.

[5] BRAGA, B.; PORTO, M.; TUCCI, C. E. M. Monitoramento de qualidade das águas. In: REBOUÇAS, A C.; BRAGA, B.; TUNDISI, J. G. Org. Águas doces no Brasil: Capitalecológico,usoeconservação. 3ed.,SãoPaulo:EscriturasEditoras,2006. cap. 5, p.145-160.

[6] CETESB - COMPANHIA DE TECNOLOGIA DE SANEAMENTO AMBIENTAL. Variáveis <http://www.cetesb.sp.gov.br/agua/rios/variaveis.asp> Acesso em: 26 set. 2012.

[7] CERETTA, M. C. Avaliação dos aspectos da qualidade da água na sub-bacia hidrográfica do Arroio Cadena Município de Santa Maria - RS. UFSM, 2004. Dissertação de Mestrado.

[8] CONSELHO NACIONAL DO MEIO AMBIENTE - CONAMA. Resolução CONAMA no 357, 2005. Disponível em: <http://www.mma.gov.br/port/conama/res/res05/res35705.pdf> Acessado em: 03 set. 2012.

[9] ESTEVES, F. de A. Fundamentos de Limnologia. Ed. Interciência, Rio de Janeiro, 1998.

[10] FONTES, A. L. e CORREIA, A. L. F. Agricultura e meio ambiente na sub-bacia do rio Jacarecica (SE). VI Simpósio Nacional de Geomofologia, 2006. Disponível em: <http://pergamum.bibliotecas.ufs.br/>. Acesso em: 09 nov. 2012.

[11] FONTES, E. M. C. A. Agricultura e meio ambiente: sustentabilidade ambiental do sistema agrícola olericultura na sub-bacia do Rio Jacarecica (SE). Universidade Federal de Sergipe, 2003. 221p. Dissertação de Mestrado.

[12] LIBÂNIO, M. Fundamentos de qualidade e tratamento de água. Campinas, SP: Editora Átomo, 2005.

[13] LIMA, W. S. e GARCIA, C. A. B. Qualidade da água em Ribeirópolis - SE: O Açude do Cajueiro e a Barragem do João Ferreira. Revista Scientia Plena. V. 4, n. 12 Disponível em: <http://www.scientiaplena.org.br>. Acesso em: 07 jan. 2013.

[14] NETTO, F. M. L., DANELON, J. R. B., RODRIGUES, S. C. Avaliação da Qualidade da Água e do uso da terra da Bacia Hidrográfica do córrego Terra Branca - Uberlândia - MG. Rev. Geogr. Acadêmica. v.5, n.2. 2011. Disponível em:<http://www.rga.ggf.br/index.php>. Acesso em:18 nov. 2012.

[15] PORTO, M. F. A; BRANCO, S. M. \& DE LUCA, S. J. Caracterização da qualidade da água. In: PORTO, R. L.L. (Org.) Hidrologia Ambiental. São Paulo: Editora da Universidade de São Paulo: Associação Brasileira de Recursos Hídricos, 1991. p. 27-66 (Coleção ABRH de Recursos Hídricos,; v. 3)

[16] PRADO, R. B. Geotecnologias aplicadas a analise espaço temporal do uso e cobertura da terra e qualidade da água do reservatório de Barra Bonita, SP, como suporte à gestão de recursos hídricos. São Carlos, Centro de Recursos Hídricos e Ecologia Aplicada, Escola de Engenharia de São Carlos, Universidade de São Paulo, 2004. Tese de Doutorado.

[17] RIBEIRO, A. F. A.; BRITO, R. F.; FRANCA, R. R. da; CARVALHO, M. E. S. Estudo Ambiental do Rio Jacarecica no Povoado Candeias, Moita Bonita - SE. Revista Geonorte. Edição Especial, V.3, N.4, p.933-945, 2012. Disponível em: <http://www.revistageonorte.ufm.edu.br/index.php>. Acesso em: 24 out. 2012. 
[18] RIBEIRO, T. A . P.; PATERNIANI, J. E. S. Microaspersores entupidos devido a problemas de ferro na água. Ciência Rural, v. 38, n. 5, p. 1456-1459. 2008.

[19] SANTOS, A. F.; ANDRADE, J. A. Nova Geografia de Sergipe. Aracaju, Secretária de EstadoeEducaçãoedoDesporteeLazer;UniversidadeFederaldeSergipe,1998.

[20] SERGIPE, Departamento Estadual de Recursos Hídricos e Irrigação de Sergipe. Fichas Técnicas, 2004.

[21] SERGIPE, SEMAH/SRH. Atlas Digital dos Recursos Hídricos. Aracaju. 2004.

[22] SILVA, M. G. da. Caracterização da qualidade da água na barragem do perímetro irrigado Jacarecica I. São Cristóvão, 2006 74p. Disponível em: <http://pergamum.bibliotecas.ufs.br/> Acesso em: 8 Ago. 2012.

[23] SPERLING, M. V. Introdução à qualidade das águas e ao tratamento de esgotos. Departamento de engenharia sanitária e ambiental UFMG, 2005. 452p.

[24] VASCO, A. N.; MELLO JÚNIOR A. V.; SANTOS, A. C. A. da S.; RIBEIRO, D. O.; TAVARES, E. D.; NOGUEIRA, L. C. Qualidade da água que entra no estuário do rio Vaza Barris pelo principal fluxo de contribuição de água doce. Revista Scientia Plena. Vol.6, n.9, 2010. Disponível em: <http://www.scientiaplena.org.br//ojs/index.php/sp>. Acesso em: 01 nov. 2012.

[25] VON SPELING, M. Introdução à qualidade das águas e ao tratamento de esgotos. 2ª edição. Belo Horizonte, 1996.

[26] WATANABE, T., COLER, R. A., e PAZ, R. J. The implementaion of a reginal biomonitoring program in northrast Brazil. Aquatic Ecosystem Health \& Management, V. 2, 1999. 


\title{
CAPÍTULO \\ Avaliação do sistema agreste de abastecimento de água potável
}

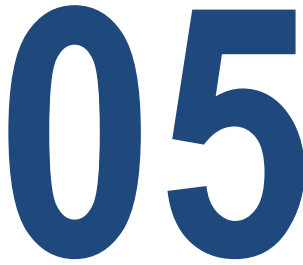

\author{
Mário Leo de Oliveira Rodrigues \\ Gregorio Guirado Faccioli
}

\section{INTRODUÇ̃̃̃O}

O saneamento básico é um dos direitos humanos que deve ser assegurado. Para isto, dentre os diversos campos de atuação da engenharia sanitária, o tratamento de água tem papel de suma importância. Assim, este estudo visa descrever e discutir o Sistema de Abastecimento do Agreste que compreende aos municípios de Areia Branca, Campo do Brito, Itabaiana, Macambira, Ribeirópolis e São Domingos e seus respectivos povoados, que são operados pela Companhia de Saneamento de Sergipe (DESO), onde alguns desses sistemas estão inclusos totalmente na área da Bacia do Rio Jacarecica e outros entorno da mesma.

Para tanto, foi necessário coletar informações junto as Supervisões Comercial e Operacional da Unidade de Negócios Centro-Oeste (UNCO) responsável pelo abastecimento de água potável na região. Tendo como base nas informações coletadas, abordamos o funcionamento dos sistemas, passando pela captação, adução, tratamento, reservação, distribuição, tipos de ligações e suas principais anomalias. Segundo a Organização Mundial da Saúde (OMS), o investimento em água potável e saneamento básico geram grandes retornos econômicos. Atualmente estima-se que 2,4 bilhões de pessoas no mundo não tenham acesso a saneamento básico, enquanto mais de 1 bilhão não tem água potável disponível. As metas para o desenvolvimento do milênio, estabelecidas em consenso pelos países membros da ONU, propõem que até 2015 mais 2 bilhões de pessoas tenham acesso a água potável e esgoto.

A água, essencial ao surgimento e à manutenção da vida em nosso planeta, é indispensável para o desenvolvimento das diversas atividades criadas pelo ser humano, e apresenta, por essa razão, valores econômicos, sociais e culturais (MIERZAWA e HESPANHOL, 2005, p 89).

A água destinada ao consumo humano deve atender a condições mínimas para que possa ser ingerida ou utilizada para fins higiênicos, o que se consegue por meio de tratamento como é realizada pela Companhia de Saneamento responsável pela região citada neste artigo. Os múltiplos usos que se fazem da água presente na Bacia Hidrográfica do Jacarecica são conflitantes, principalmente para o abastecimento doméstico, pois a qualidade da água bruta disponível tem piorado ao longo dos anos, devido à expansão demográfica, à ocupação urbana nas margens dos mananciais, à falta de proteção por inexistência de matas ciliares, à poluição e contaminação causada por despejos urbanos, industriais, agrícolas, principalmente em decorrência do desenvolvimento agrícola e industrial e à conseqüente eutrofização.

Com o aumento da população e o incremento do comércio e da indústria na região, a água passou a ser cada vez mais utilizada, como se fosse um recurso abundante e infinito. 0 conceito de abundância de água ainda é muito forte, principalmente no Brasil, um dos países que mais dispõem desse recurso, pois cerca de $13 \%$ de toda a água doce do planeta encontra-se em território brasileiro. 0 problema com a água no Brasil diz respeito à sua distribuição já que as perdas de água totais em sistemas de abastecimento no Brasil têm uma média de 40,5\%, valor considerado muito elevado, necessitando, portanto urgentemente uma redução de pelo menos $30 \%$ em curto prazo e de $50 \%$ em médio prazo, em face desta situação é necessário relatar que mais de $2 \%$ do consumo total de energia elétrica do Brasil são consumidos pelos prestadores de serviços de saneamento, sendo que $90 \%$ dessa energia são consumidas pelos conjuntos motobomba.

Este artigo tem como objetivo geral caracterizar e avaliar os sistemas de abastecimento de água potável dos municípios e seus povoados que fazem parte do Sistema do Agreste e como objetivos específicos 
levantar as características de cada sistema, tipos de ligações, verificar as principais anomalias no sistema de micromedição e apresentar os índices das anomalias encontradas.

Para chegarmos aos objetivos propostos, adotamos os seguintes procedimentos metodológicos, foram feitos levantamentos bibliográficos em teses, artigos e documentos de Companhias de Saneamento, visando dados literários acerca da questão das perdas e gestão do recurso hídrico em sistemas de abastecimento, foram elaborados instrumentos de coleta de dados, tipo tabela, levantados dados em campo para preenchimento dessas tabelas e outros informados pelos sistemas operacionais e comerciais da Companhia de Saneamento, foram feitos processamento e análise desses dados e a criação de índices para observamos a atual situação do sistema. Tendo como base nas informações coletadas, abordamos o funcionamento de todo o sistema, tipos de ligações, além das 04 ocorrências mais relevantes de anomalias na micromedição desses sistemas.

Nota-se também que as empresas de saneamento do país estão atualmente direcionando e aprimorando as suas atividades no que tange ao controle de perdas para diminuir as despesas operacionais e a quantidade de água bruta captada dos mananciais uma vez que os índices constatados se apresentam elevados. Os sistemas de abastecimento dos municípios em torno oferecidas pela Unidade de Negócios Centro-Oeste, com a identificação das anomalias funcionais do sistema de micromedição é necessário implementar ações para reduzir as perdas, diminuir as despesas operacionais e a quantidade captada nos mananciais aumentando assim disponibilidade do recurso para que seja possível atender outras demandas.

Faz-se necessário para resolver esses problemas implantar políticas no sistema de macromedição, setorização, na micromedição, correção das irregularidades nos ramais prediais, substituição de hidrômetros que apresentam anomalias funcionais e melhor controle operacional do sistema distribuidor, aonde aos poucos a Unidade vem se aprimorando com a ampliação da automação do Sistema do Agreste que abrange os municípios de Areia Branca, Campo do Brito, Itabaiana, Macambira, e São Domingos e seus respectivos povoados, compreendendo a $83 \%$ dos sistemas dos municípios entorno Bacia Hidrográfica do Jacarecica.

\section{CARACTERIZAÇÃO DOS SISTEMAS DE ABASTECIMENTO}

A produção de água de boa qualidade depende de um bom controle operacional dos diversos processos e operações unitárias de tratamento, a água coletada do manancial é levada à ETA por meio de um sistema de captação que é constituído de estruturas e dispositivos para a sua retirada e destinação ao sistema de abastecimento. A maioria dos sistemas possui estação elevatória, que é um conjunto de obras destinadas a recalcar a água para a unidade seguinte ou aumentar a vazão e/ou pressão em adutoras ou redes de distribuição de água. As adutoras são canalizações que conduzem a água entre as unidades que precedem a rede de distribuição ou entre a captação e ETA. A ETA define-se como as unidades destinadas a tratar a água, seguindo-se padrões de potabilidade e após ser tratada, a água é destinada a um reservatório que regulariza as variações entre as vazões de adução e de distribuição e condiciona as pressões na rede de distribuição, esta última finalizando o sistema e responsável por colocar água potável à disposição dos consumidores por meio de tubulações, como está representado na tabela a seguir.

Para o planejamento e gerenciamento de sistemas de abastecimento de água, a previsão do consumo de água é um dos fatores de fundamental importância. A operação dos sistemas e as suas ampliações e/ou melhorias estão diretamente associadas à demanda de água. Os consumidores de água são classificados em quatro categorias de consumo pelas prestadoras de serviços de saneamento, são elas doméstica, comercial, industrial e pública. A categoria de economias residenciais é a mais homogênea, apresentando uma variabilidade de consumo relativamente pequena, quando comparada à variabilidade das outras. As categorias comercial e industrial são mais heterogêneas. 
Tabela 1-Constituição dos Sistemas de Abastecimento e Distribuição de Água.

\begin{tabular}{l|l|l}
\multicolumn{1}{c|}{ MACRO PROCESSO } & \multicolumn{2}{c}{ UNIDADE } \\
Captação & Estações de Captação & $\begin{array}{l}\text { Captar água bruta nas origens superficiais e/ou subterrâneas, de acordo com } \\
\text { as disponibilidades e as necessidades. }\end{array}$ \\
\hline Elevação & Estações Elevatórias & $\begin{array}{l}\text { Bombear água bruta ou tratada entre um ponto de cota mais baixa e um ou } \\
\text { mais pontos de cota mais elevada. }\end{array}$ \\
\hline Transporte ou Adução & $\begin{array}{l}\text { Adutoras, Aquedutos e } \\
\text { Canais }\end{array}$ & $\begin{array}{l}\text { Conjunto de obras destinadas a transportar a água desde a origem à } \\
\text { distribuição, que pode ser em pressão por gravidade e por bombeamento ou } \\
\text { com superficie livre por meio de aquedutos e canais. }\end{array}$ \\
\hline Tratamento & $\begin{array}{l}\text { Estações de Tratamento de } \\
\text { Água (ETA) }\end{array}$ & $\begin{array}{l}\text { Produzir a água potável a partir de água bruta, obedecendo às normas de } \\
\text { qualidade (Decreto-Lei 236 de 1 de Agosto 1998). }\end{array}$ \\
\hline Armazenamento & $\begin{array}{l}\text { Reservatórios (Elevados e } \\
\text { Apoiados) }\end{array}$ & $\begin{array}{l}\text { Servir de volante de regularização, compensando as flutuações de consumo } \\
\text { face à adução. Constituir reservas de emergência como combate a incêndios } \\
\text { ou em casos de interrupção voluntária ou acidental do sistema além de } \\
\text { equilibrar as pressões na rede de distribuição. }\end{array}$ \\
\hline Distribuição & $\begin{array}{l}\text { Rede Geral Pública de } \\
\text { Distribuição de Água }\end{array}$ & $\begin{array}{l}\text { Conjunto de tubulaçóes e vários elementos acessórios para transportar a água } \\
\text { para vários tipos de distribuição. }\end{array}$ \\
\hline Ligação & Ramais de Ligação & $\begin{array}{l}\text { Asseguram o abastecimento predial de água, desde a rede pública até ao } \\
\text { limite da propriedade a servir, em boas condições de vazão e pressão. }\end{array}$ \\
\hline
\end{tabular}

Fonte: Macro Processos- ADE, 2013.

\section{PERDAS DE ÁGUA NOS SISTEMAS}

As elevadas perdas de água tornaram-se um dos maiores problemas dos sistemas de abastecimento de água brasileiro. Contribuem para tal situação, dentre outros motivos, a baixa capacidade institucional e de gestão dos sistemas; a pouca disponibilidade de recursos para investimentos, sobretudo em ações de desenvolvimento tecnológico na rede de distribuição e na operação dos sistemas; a cultura do aumento da oferta e do consumo individual, sem preocupações com a conservação e o uso racional; e as decisões pragmáticas de ampliação da carga hidráulica e extensão das redes até áreas mais periféricas dos sistemas, para atendimento aos novos consumidores, sem os devidos estudos de engenharia (MIRANDA, 2006). Combater e controlar a perda é uma questão fundamental, em cenários em que há, por exemplo: escassez de água e conflitos pelo seu uso; elevados volumes de água não faturadas, comprometendo a saúde financeira do operador; um ambiente de regulação, em que os indicadores que retratam as perdas de água estão entre os mais valorizados para a avaliação de desempenho.

0 gerenciamento das perdas exige o seu conhecimento pleno e identificar e quantificar as perdas constitui-se em ferramenta essencial e indispensável para a implementação de ações de combate (TARDELI FILHO, 2004, p 56).

Nos sistemas de abastecimento e distribuição de água entende-se por perdas e fugas todo o volume de água que não é faturado. 0 volume de água não faturado pode, em termos gerais, ser dividido nas seguintes parcelas:

- Perdas Físicas, que correspondem aos volumes de água não faturados e não consumidos;

- Perdas Não Físicas, que correspondem aos volumes de água não faturados, mas consumidos.

As perdas físicas, são ligadas estritamente à rede de distribuição de água, correspondem às rupturas que se verificam ao longo de todo o sistema, envolvendo a ruptura de tubulação e perdas em reservatórios, além das decorrentes dos procedimentos de descargas ou purgas na rede. As perdas não físicas têm origem distinta, podendo ser equacionadas as seguintes causas principais: ligações clandestinas; ligações sem contador (por exemplo, nos casos de chafarizes, bocas de rega e de lavagem, hidrantes, entre outros); contadores com funcionamento anômalo e erros de leitura de contadores.

Ao analisarmos as ocorrências de vazamentos registradas no sistema comercial GSAM através dos Registros de Atendimentos efetuados nos municípios e seus respectivos povoados nos escritórios da UNCO, observamos que as características das ocorrências no Sistema do Agreste são semelhantes aos índices identificados por CHAMA NETO como vemos na figura abaixo: 
Figura 1-Freqüência de Vazamentos em Rede, Ramal Predial e Cavalete.

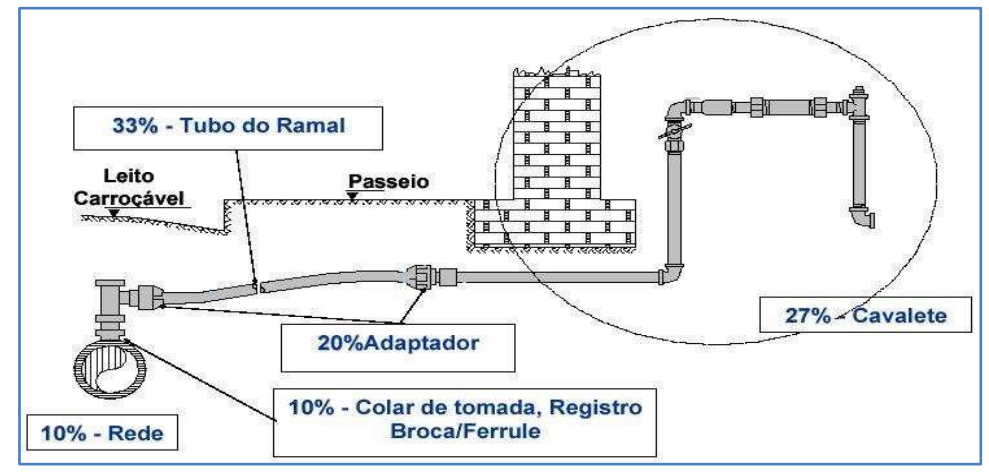

Fonte: CHAMA NETO (2006).

A redução das perdas físicas permite diminuir os custos de produção e ampliar a capacidade do sistema sem investimentos adicionais, enquanto que a redução das perdas não físicas permite aumentar a faturação, melhorando a eficiência dos serviços prestados e o desempenho financeiro da entidade gestora. Um programa de combate às perdas e fugas exige a adoção de medidas que permitam reduzir as perdas físicas e não físicas, e mantê-las permanentemente em nível adequado, considerando a viabilidade técnico- econômica das ações desencadeadas em relação ao processo operacional de todo o sistema. Neste sentido, é indispensável à realização de um diagnóstico da situação preciso, por forma a conhecer-se, com o máximo rigor possível, o que são perdas físicas e não físicas, e estabelecerem-se as medidas de ação adequadas ao seu combate.

\section{SISTEMA DE ABASTECIMENTO DO MUNICÍPIO DE AREIA BRANCA}

A sede dispõe de sistema de abastecimento de água tratada atendido pelo Sistema do Agreste, não possui sistema de tratamento de esgoto lançando assim seus efluentes "in natura" na drenagem pluvial, valas, lagos ou rios próximos à sede municipal. Possui 03 (três) povoados sendo um atendido pelo Sistema Agreste e os outros por Sistemas Independentes como mostra nas tabelas a seguir, que apresentam as características dos sistemas, quantidades e as características das ligações existentes.

Tabela 2-Características dos Sistemas de Abastecimento no Município.

\begin{tabular}{|c|c|c|}
\hline LOCALIDADES & Areia Branca / Pov. Manilha & Pov. Ladeira / Pov. Pedrinhas \\
\hline NOME DO SISTEMA & Sistema Integrado do Agreste & Independente \\
\hline NOME DA CAPITAÇÃO & Barragem Jacarecica II & Poço \\
\hline TIPO DO MANANCIAL & Superficial & Subterrâneo \\
\hline QUANTIDADES DE POÇOS & & 1 \\
\hline OPERAÇÃO EM ETA & Sim & Não \\
\hline ETA AUTOMATIZADA & Não & \\
\hline REGIME DE FUNCIONAMENTO DA ETA & 24 horas & Bombeamento 24 horas \\
\hline TIPO DE TRATAMENTO & Floto-Filtração & Simples Desinfecção \\
\hline QUANTIDADES DE FILTROS & 3 & \\
\hline VAZÃO L/S & 120 & 49 \\
\hline PORTE DA ETA/SISTEMA & Médio & Pequeno \\
\hline QUANTIDADE DE RESERVATÓRIOS & 4 & 1 \\
\hline TIPO DE RESERVATÓRIO & 2 Apoiados / 2 Elevados & Elevado \\
\hline CAPACIDADE DE RESERVATÓRIO EM M M & $700,500,150$ e 100 & 100 \\
\hline
\end{tabular}


Ao analisamos os dados coletados em campo e junto à supervisão comercial, chegamos à conclusão que 11,03\% das ligações reais do município estão suprimidas, ou seja, com corte de fornecimento definitivo sem gerar talão de cobrança, ligações que necessitam serem constantemente fiscalizadas para que sejam evitadas as religações clandestinas, que apresentam as características dos sistemas e as quantidades e as características das ligações existentes nos mesmos.

Tabela 3-Características das Ligações do Município.

\begin{tabular}{|c|c|c|c|c|c|c|c|c|c|c|c|}
\hline \multirow{2}{*}{$\begin{array}{l}\text { MUNICÍPIO/ } \\
\text { POVOADOS }\end{array}$} & \multicolumn{2}{|c|}{ RESIDENCIAL } & \multicolumn{2}{|c|}{ COMERCIAL } & \multicolumn{2}{|c|}{ INDUSTRIAL } & \multicolumn{2}{|c|}{ PÚBLICO } & \multicolumn{3}{|c|}{ LIGAÇÕES } \\
\hline & C/HID & S/HID & C/HID & S/HID & C/HID & S/HID & C/HID & S/HID & ATIVAS & SUPRI. & REAIS \\
\hline Areia Branca & 3.077 & - & 27 & - & - & - & 28 & - & 3.132 & 297 & 3.429 \\
\hline Pov. Ladeira & 47 & - & - & - & - & - & 1 & - & 48 & 13 & 61 \\
\hline Pov. Pedrinhas & 541 & - & 6 & - & - & - & 4 & - & 551 & 114 & 665 \\
\hline Pov. Manilha & 153 & - & - & - & - & - & 3 & - & 156 & 58 & 214 \\
\hline TOTAL & 3.818 & - & 33 & - & - & - & 36 & - & 3.887 & 482 & 4.369 \\
\hline
\end{tabular}

Fonte: Fonte: GSAN - Gestão de Sistema de Saneamento-DESO-UNCO-2013.

As quatro mais recorrentes ocorrências de anomalias na micromedição desse sistema foram coletas, e após serem analisadas chegamos à conclusão que somadas elas correspondem a 14,19\% das ligações ativas, como mostra a tabela abaixo. Em face desta situação as informações coletadas nas leituras não revelam o real consumo, pois quando efetuada a leitura no hidrômetro é considerada a média dos consumos anteriores, gerando assim dados inconsistentes.

Tabela 4- Ocorrências das anomalias na micromedição

\begin{tabular}{c|c|c|c|c|c|c|c|c}
\hline \multirow{2}{*}{$\begin{array}{c}\text { Município/ } \\
\text { povoados }\end{array}$} & \multicolumn{7}{|c|}{ Ocorrências } & Parado \\
\cline { 2 - 9 } & $\%$ & Quebra & $\%$ & Suado & $\%$ & Soter & $\%$ \\
\hline Areia Branca & 306 & 9,77 & 89 & 2,84 & 29 & 0,93 & 22 & 0,7 \\
\hline Pov. Ladeira & 7 & 14,58 & - & 0 & - & 0 & - & 0 \\
\hline Pov. Pedrinhas & 77 & 13,97 & 5 & 0,91 & 1 & 0,18 & 1 & 0,18 \\
\hline Pov. Manilha & 14 & 8,97 & 1 & 0,64 & - & 0 & - & 0 \\
\hline TOTAL & 404 & 10,39 & 95 & 2,44 & 30 & 0,77 & 23 & 0,59 \\
\hline
\end{tabular}

\section{SISTEMA DE ABASTECIMENTO DO MUNICÍPIO DE CAMPO DO BRITO}

A sede dispõe de sistema de abastecimento de água tratada, o município é atendido pelo Sistema do Agreste, não possui sistema de tratamento de esgoto lançando assim seus efluentes "in natura" na drenagem pluvial, valas, lagos ou rios próximos à sede municipal. Possui 12 (doze) povoados atendidos pelo Sistema Agreste como mostra nas tabelas a seguir, que apresentam as características dos sistemas, as quantidades e as características das ligações existentes nos mesmos. 
Tabela 5-Características dos Sistemas de Abastecimento no Município.

\begin{tabular}{|c|c|c|c|c|c|c|}
\hline Nome da capitação & $\begin{array}{l}\text { Captação da } \\
\text { Cajaíba }\end{array}$ & $\begin{array}{c}\text { Captação da } \\
\text { Cajaíba }\end{array}$ & $\begin{array}{l}\text { Captação da } \\
\text { Cajaiba }\end{array}$ & $\begin{array}{l}\text { Captação da } \\
\text { Cajaiba }\end{array}$ & $\begin{array}{l}\text { Captação da } \\
\text { Cajaíba }\end{array}$ & $\begin{array}{l}\text { Captação da } \\
\text { Cajaíba }\end{array}$ \\
\hline \multicolumn{7}{|l|}{ Quantidades de poços } \\
\hline Operação em eta & Não & Não & Não & Não & Não & Não \\
\hline Eta automatizada & Não & Não & Não & Não & Não & Não \\
\hline Regime de funcionamento & \multicolumn{6}{|c|}{24 Horas } \\
\hline Porte do sistema & \multicolumn{6}{|c|}{ Médio } \\
\hline $\begin{array}{l}\text { Quantidade de } \\
\text { reservatórios }\end{array}$ & 3 & 1 & 0 & 1 & 0 & 1 \\
\hline Tipo de reservatório & $\begin{array}{l}2 \text { Apoiados / } 1 \\
\text { Elevado }\end{array}$ & Elevado & & Elevado & & Elevado \\
\hline $\begin{array}{l}\text { Capacidade de reservatório } \\
\text { em m }{ }^{3}\end{array}$ & 700,200 e 150 & 250 & & 150 & & 100 \\
\hline
\end{tabular}

Fonte: Supervisão Operacional UNCO, 2013.

Tabela 5.1-Características dos Sistemas de Abastecimento no Município.

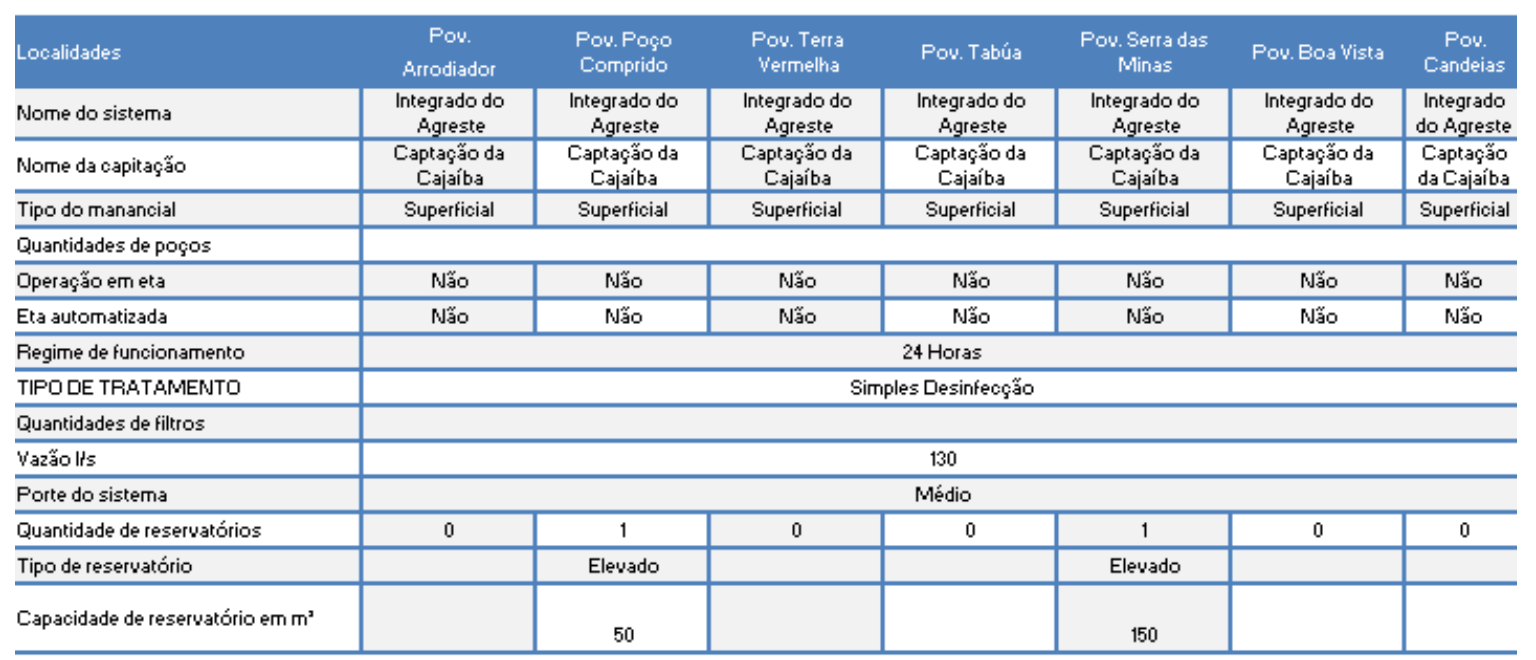

Fonte: Supervisão Operacional UNCO, 2013.

Ao analisamos os dados coletados em campo e junto à supervisão comercial, chegamos à conclusão que $16,36 \%$ das ligações reais do município estão suprimidas, ou seja, com corte de fornecimento definitivo sem gerar talão de cobrança, ligações que necessitam serem constantemente fiscalizadas para que sejam evitadas as religações clandestinas. 
Tabela 6-Características das Ligações do Município.

\begin{tabular}{|c|c|c|c|c|c|c|c|c|c|c|c|}
\hline \multirow{2}{*}{$\begin{array}{l}\text { MUNICÍPIO/ } \\
\text { POVOADOS }\end{array}$} & \multicolumn{4}{|c|}{ RESIDENCIALCOMERCIAL } & \multicolumn{2}{|c|}{ INDUSTRIAL } & \multicolumn{2}{|c|}{ PÚBLICO } & \multicolumn{3}{|c|}{ LIGAÇÕES } \\
\hline & $\begin{array}{l}\text { C/ } \\
\text { HID }\end{array}$ & S/HID & $\mathrm{C} / \mathrm{HID}$ & $\begin{array}{l}\text { S/ } \\
\text { HID }\end{array}$ & $\begin{array}{l}\text { C/ } \\
\text { HID }\end{array}$ & $\begin{array}{l}\text { S/ } \\
\text { HID }\end{array}$ & C/ HID & $\begin{array}{l}\text { S/ } \\
\text { HID }\end{array}$ & ATIVAS & SUPRI. & REAIS \\
\hline Campo do Brito & 3.399 & 2 & 57 & 1 & 1 & - & 36 & - & 3.496 & 379 & 3.875 \\
\hline Pov. Garangal & 34 & - & - & - & - & - & 3 & - & 37 & 35 & 72 \\
\hline $\begin{array}{l}\text { Pov. Caatinga } \\
\text { Redonda }\end{array}$ & 63 & - & - & - & - & - & 2 & - & 65 & 33 & 98 \\
\hline Pov. Gameleira & 15 & - & 1 & - & - & - & 1 & & 17 & 63 & 80 \\
\hline $\begin{array}{l}\text { Pov. Tapera da } \\
\text { Serra }\end{array}$ & 80 & - & - & - & - & - & 2 & - & 82 & 34 & 116 \\
\hline Pov. Brito Velho & 58 & - & - & - & - & - & 1 & - & 59 & 10 & 69 \\
\hline Pov. Arrodiador & 75 & 1 & 1 & - & - & - & 2 & - & 79 & 14 & 93 \\
\hline $\begin{array}{l}\text { Pov. Poço } \\
\text { Comprido }\end{array}$ & 101 & - & - & - & - & - & 2 & - & 103 & 11 & 114 \\
\hline $\begin{array}{l}\text { Pov. Terra } \\
\text { Vermelha }\end{array}$ & 79 & - & - & - & - & - & 3 & - & 82 & 24 & 106 \\
\hline Pov. Tábua & 11 & - & - & - & - & - & 1 & - & 12 & 9 & 21 \\
\hline $\begin{array}{l}\text { Pov. Serra das } \\
\text { Minas }\end{array}$ & 73 & - & - & - & - & - & 1 & - & 74 & 38 & 112 \\
\hline Pov. Boa Vista & 49 & - & - & - & - & - & 1 & - & 50 & 9 & 59 \\
\hline Pov. Candeias & 232 & 8 & - & - & - & - & 5 & - & 245 & 202 & 447 \\
\hline TOTAL & 4.269 & 11 & 59 & 1 & 1 & - & 60 & - & 4.401 & 861 & 5.262 \\
\hline
\end{tabular}

Fonte: Fonte: GSAN - Gestão de Sistema de Saneamento-DESO-UNCO-2013.

As quatro mais recorrentes ocorrências de anomalias na micromedição desse sistema foram coletas, e após serem analisadas chegamos à conclusão que somadas elas correspondem a 5,96\% das ligações ativas, como mostra a tabela abaixo. Em face desta situação as informações coletadas nas leituras não revelam o real consumo, pois quando efetuada a leitura no hidrômetro é considerada a média dos consumos anteriores, gerando assim dados inconsistentes.

Tabela 7-Características das Anomalias das Ligações do Município.

\begin{tabular}{|c|c|c|c|c|c|c|c|c|}
\hline \multirow[b]{2}{*}{ MUNICÍPIO/POVOADOS } & \multicolumn{8}{|c|}{ OCORRÊNCIAS } \\
\hline & PARADO & $\%$ & QUEBRA. & $\%$ & SUADO & $\%$ & $\begin{array}{c}\text { SOT } \\
\text { ER }\end{array}$ & $\%$ \\
\hline Campo do Brito & 169 & 4,83 & 8 & 0,23 & 11 & 0,31 & 4 & 0,11 \\
\hline Pov. Garangal & 2 & 5,41 & - & 0,00 & - & 0,00 & - & 0,00 \\
\hline Pov. Caatinga Redonda & 6 & 9,23 & - & 0,00 & - & 0,00 & - & 0,00 \\
\hline Pov. Gameleira & - & 0,00 & - & 0,00 & 1 & 5,88 & - & 0,00 \\
\hline Pov. Tapera da Serra & 14 & 17,07 & - & 0,00 & 1 & 1,22 & - & 0,00 \\
\hline Pov. Brito Velho & 3 & 5,08 & 1 & 1,69 & - & 0,00 & - & 0,00 \\
\hline Pov. Arrodiador & 1 & 1,27 & 1 & 1,27 & - & 0,00 & - & 0,00 \\
\hline Pov. Poço Comprido & 4 & 3,88 & 2 & 1,94 & - & $\mathbf{0 , 0 0}$ & - & 0,00 \\
\hline Pov. Terra Vermelha & 5 & 6,10 & - & 0,00 & 1 & 1,22 & - & 0,00 \\
\hline Pov. Tábua & 1 & 8,33 & - & 0,00 & 1 & 8,33 & - & 0,00 \\
\hline Pov. Serra das Minas & 7 & 9,46 & - & 0,00 & 1 & 1,35 & - & 0,00 \\
\hline Pov. Boa Vista & - & 0,00 & - & 0,00 & - & 0,00 & - & 0,00 \\
\hline Pov. Candeias & 12 & 4,90 & 2 & 0,82 & 1 & 0,41 & 3 & 1,22 \\
\hline TOTAL & 224 & 5,09 & 14 & 0,32 & 17 & 0,39 & 7 & 0,16 \\
\hline
\end{tabular}

Fonte: Fonte: GSAN - Gestão de Sistema de Saneamento-DESO-UNCO-2013. 


\section{SISTEMA DE ABASTECIMENTO DO MUNICÍPIO DE ITABAIANA}

A sede dispõe de sistema de abastecimento de água tratada, o município é atendido pelo Sistema do Agreste e não possui sistema de tratamento de esgoto lançando assim seus efluentes "in natura" na drenagem pluvial, valas, lagos ou rios próximos à sede municipal. Possui 18 (dezoito) povoados atendidos pelo Sistema Agreste, como mostra nas tabelas abaixo, que apresentam as características dos sistemas, as quantidades e as características das ligações existentes nos mesmos.

Tabela 8-Características dos Sistemas de Abastecimento no Município.

\begin{tabular}{|c|c|c|c|c|c|}
\hline Localidades & Itabaiana & Pov. Cajaíba & $\begin{array}{c}\text { Pov. } \\
\text { Queimadas }\end{array}$ & Pov. Ribeira & $\begin{array}{l}\text { Pov. Rio das } \\
\text { Pedras }\end{array}$ \\
\hline Nome do sistema & $\begin{array}{c}\text { Sistema } \\
\text { Integrado do } \\
\text { Agreste / } \\
\text { Barragem Cajaíba }\end{array}$ & $\begin{array}{c}\text { Sistema } \\
\text { Integrado do } \\
\text { Agreste / } \\
\text { Barragem } \\
\text { Cajaíba }\end{array}$ & $\begin{array}{c}\text { Sistema } \\
\text { Integrado do } \\
\text { Agreste / } \\
\text { Barragem } \\
\text { Cajaíba }\end{array}$ & $\begin{array}{c}\text { Sistema } \\
\text { Integrado do } \\
\text { Agreste / } \\
\text { Barragem } \\
\text { Cajaíba }\end{array}$ & $\begin{array}{c}\text { Sistema } \\
\text { Integrado do } \\
\text { Agreste / } \\
\text { Barragem } \\
\text { Cajaíba }\end{array}$ \\
\hline Nome da capitação & $\begin{array}{l}\text { Jacarecica II, } \\
\text { Barragem da } \\
\text { Cajaíba, } \\
\text { Barragem da } \\
\text { Ribeira }\end{array}$ & $\begin{array}{l}\text { Jacarecica II, } \\
\text { Barragem da } \\
\text { Cajaíba, } \\
\text { Barragem da } \\
\text { Ribeira }\end{array}$ & $\begin{array}{l}\text { Jacarecica II, } \\
\text { Barragem da } \\
\text { Cajaíba, } \\
\text { Barragem da } \\
\text { Ribeira }\end{array}$ & $\begin{array}{l}\text { Jacarecica II, } \\
\text { Barragem da } \\
\text { Cajaíba, } \\
\text { Barragem da } \\
\text { Ribeira }\end{array}$ & $\begin{array}{c}\text { Jacarecica II, } \\
\text { Barragem da } \\
\text { Cajaíba, } \\
\text { Barragem da } \\
\text { Ribeira }\end{array}$ \\
\hline Tipo do manancial & Superficial & Superficial & Superficial & Superficial & Superficial \\
\hline Quantidades de poços & & & & & \\
\hline Operação em eta & \multicolumn{5}{|c|}{ Sim } \\
\hline Eta automatizada & \multicolumn{5}{|c|}{ Não } \\
\hline Regime de Funcionamento & \multicolumn{2}{|c|}{24 Horas } & 8 Horas & 8 Horas & 8 Horas \\
\hline Tipo de tratamento & \multicolumn{5}{|c|}{ Filtração Direta Descendente } \\
\hline Quantidades de Filtros & \multicolumn{5}{|c|}{4} \\
\hline Vazão l/s & \multicolumn{5}{|c|}{$720 \mathrm{~m}^{3}$} \\
\hline Porte da eta & \multicolumn{5}{|c|}{ Grande } \\
\hline $\begin{array}{l}\text { Quantidade de } \\
\text { Reservatórios }\end{array}$ & 8 & 1 & 1 & 1 & 1 \\
\hline Tipo de Reservatório & $\begin{array}{l}04 \text { Apoiados / } 04 \\
\text { Elevados }\end{array}$ & Elevado & Elevado & Elevado & Elevado \\
\hline $\begin{array}{l}\text { Capacidade de } \\
\text { reservatório em m³ }\end{array}$ & $\begin{array}{c}1000,1000,350 \\
350,4000,400 \\
400,400\end{array}$ & 100 & 100 & 100 & 100 \\
\hline
\end{tabular}

Fonte: Supervisão Operacional

Tabela 8.1-Características dos Sistemas de Abastecimento no Município.

\begin{tabular}{|c|c|c|c|c|c|}
\hline Localidades & $\begin{array}{l}\text { Pov. Terra } \\
\text { Dura }\end{array}$ & Pov. Carrilho & $\begin{array}{c}\text { Pov. } \\
\text { Queimadinhas }\end{array}$ & Pov. Prensa & $\begin{array}{c}\text { Pov. } \\
\text { Vermelho }\end{array}$ \\
\hline Nome do sistema & $\begin{array}{l}\text { Sistema } \\
\text { Integrado do } \\
\text { Agreste / } \\
\text { Barragem } \\
\text { Cajaíba }\end{array}$ & $\begin{array}{l}\text { Sistema } \\
\text { Integrado do } \\
\text { Agreste / } \\
\text { Barragem } \\
\text { Cajaíba }\end{array}$ & $\begin{array}{c}\text { Sistema Integrado } \\
\text { do Agreste / } \\
\text { Barragem Cajaíba }\end{array}$ & $\begin{array}{l}\text { Sistema } \\
\text { Integrado do } \\
\text { Agreste / } \\
\text { Barragem } \\
\text { Cajaíba }\end{array}$ & $\begin{array}{c}\text { Sistema } \\
\text { Integrado do } \\
\text { Agreste / } \\
\text { Barragem } \\
\text { Cajaíba }\end{array}$ \\
\hline Nome da capitação & $\begin{array}{l}\text { Jacarecica II, } \\
\text { Barragem da } \\
\text { Cajaíba, } \\
\text { Barragem da } \\
\text { Ribeira }\end{array}$ & $\begin{array}{l}\text { Jacarecica II, } \\
\text { Barragem da } \\
\text { Cajaíba, } \\
\text { Barragem da } \\
\text { Ribeira }\end{array}$ & $\begin{array}{c}\text { Jacarecica II, } \\
\text { Barragem da } \\
\text { Cajaíba, Barragem } \\
\text { da Ribeira }\end{array}$ & $\begin{array}{l}\text { Jacarecica II, } \\
\text { Barragem da } \\
\text { Cajaíba, } \\
\text { Barragem da } \\
\text { Ribeira }\end{array}$ & $\begin{array}{c}\text { Jacarecica II, } \\
\text { Barragem da } \\
\text { Cajaíba, } \\
\text { Barragem da } \\
\text { Ribeira }\end{array}$ \\
\hline Tipo do manancial & Superficial & Superficial & Superficial & Superficial & Superficial \\
\hline \multicolumn{6}{|l|}{ Quantidades de poços } \\
\hline Operação em eta & \multicolumn{5}{|c|}{ Sim } \\
\hline Eta automatizada & \multicolumn{5}{|c|}{ Não } \\
\hline Regime de funcionamento & 8 Horas & 8 Horas & 8 Horas & 8 Horas & 8 Horas \\
\hline Tipo de tratamento & \multicolumn{5}{|c|}{ Filtração Direta } \\
\hline Quantidades de filtros & \multicolumn{5}{|c|}{4} \\
\hline Vazão l/s & \multicolumn{5}{|c|}{720} \\
\hline Porte da eta & \multicolumn{5}{|c|}{ Grande } \\
\hline $\begin{array}{l}\text { Quantidade de } \\
\text { reservatórios }\end{array}$ & 1 & 1 & & & \\
\hline Tipo de reservatório & Elevado & Elevado & & & \\
\hline $\begin{array}{l}\text { Capacidade de } \\
\text { Reservatório em } \mathrm{m}^{3}\end{array}$ & 100 & 100 & & & \\
\hline
\end{tabular}


Tabela 8.2-Características dos Sistemas de Abastecimento no Município.

\begin{tabular}{|c|c|c|c|c|c|}
\hline Localidades & Pov. Gandu I & Pov. Gandu II & $\begin{array}{l}\text { Pov. Lagoa do } \\
\text { Forno }\end{array}$ & Pov. Taboca & $\begin{array}{c}\text { Pov. } \\
\text { Dendezeiro }\end{array}$ \\
\hline Nome do sistema & $\begin{array}{c}\text { Sistema } \\
\text { Integrado do } \\
\text { Agreste / } \\
\text { Barragem } \\
\text { Cajaíba } \\
\text { Jacarecica II, }\end{array}$ & $\begin{array}{c}\text { Sistema } \\
\text { Integrado do } \\
\text { Agreste / } \\
\text { Barragem } \\
\text { Cajaíba } \\
\text { Jacarecica II, }\end{array}$ & $\begin{array}{c}\text { Sistema } \\
\text { Integrado do } \\
\text { Agreste / } \\
\text { Barragem } \\
\text { Cajaíba } \\
\text { Jacarecica II, }\end{array}$ & $\begin{array}{c}\text { Sistema } \\
\text { Integrado do } \\
\text { Agreste / } \\
\text { Barragem } \\
\text { Cajaíba } \\
\text { Jacarecica II, }\end{array}$ & $\begin{array}{c}\text { Sistema } \\
\text { Integrado do } \\
\text { Agreste / } \\
\text { Barragem } \\
\text { Cajaíba } \\
\text { Jacarecica II, }\end{array}$ \\
\hline Nome da capitação & $\begin{array}{l}\text { Barragem da } \\
\text { Cajaíba, } \\
\text { Barragem da } \\
\text { Ribeira }\end{array}$ & $\begin{array}{l}\text { Barragem da } \\
\text { Cajaíba, } \\
\text { Barragem da } \\
\text { Ribeira }\end{array}$ & $\begin{array}{l}\text { Barragem da } \\
\text { Cajaíba, } \\
\text { Barragem da } \\
\text { Ribeira }\end{array}$ & $\begin{array}{l}\text { Barragem da } \\
\text { Cajaíba, } \\
\text { Barragem da } \\
\text { Ribeira }\end{array}$ & $\begin{array}{l}\text { Barragem da } \\
\text { Cajaíba, } \\
\text { Barragem da } \\
\text { Ribeira }\end{array}$ \\
\hline Tipo do manancial & Superficial & Superficial & Superficial & Superficial & Superficial \\
\hline Quantidades de poços & & & & & \\
\hline Operação em eta & \multicolumn{5}{|c|}{ Sim } \\
\hline Eta automatizada & \multicolumn{5}{|c|}{ Não } \\
\hline $\begin{array}{l}\text { Regime de } \\
\text { Funcionamento }\end{array}$ & \multicolumn{5}{|c|}{8 Horas } \\
\hline Tipo de tratamento & \multicolumn{5}{|c|}{ Filtração Direta } \\
\hline $\begin{array}{l}\text { Quantidades de } \\
\text { Filtros }\end{array}$ & \multicolumn{5}{|c|}{ 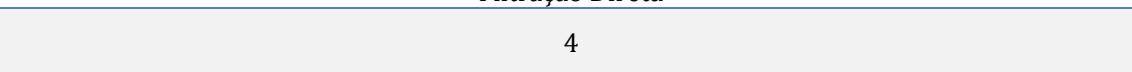 } \\
\hline Vazão l/s & \multicolumn{5}{|c|}{720} \\
\hline Porte da eta & \multicolumn{5}{|c|}{ Grande } \\
\hline $\begin{array}{l}\text { Quantidade de } \\
\text { reservatórios }\end{array}$ & & & & & \\
\hline Tipo de reservatório & & & & & \\
\hline $\begin{array}{l}\text { Capacidade de } \\
\text { reservatório em } \mathrm{m}^{3}\end{array}$ & & & & & \\
\hline
\end{tabular}

Fonte: Supervisão Operacional UNCO, 2013.

Tabela 8.3-Características dos Sistemas de Abastecimento no Município.

\begin{tabular}{|c|c|c|c|c|}
\hline Localidades & Pov. Mundo Novo & Pov. São José & Pov. Forno & Pov. Mangabeira \\
\hline Nome do sistema & $\begin{array}{l}\text { Sistema Integrado } \\
\text { do Agreste / } \\
\text { Barragem Cajaíba }\end{array}$ & $\begin{array}{c}\text { Sistema Integrado } \\
\text { do Agreste / } \\
\text { Barragem Cajaíba }\end{array}$ & $\begin{array}{c}\text { Sistema Integrado } \\
\text { do Agreste / } \\
\text { Barragem Cajaíba }\end{array}$ & $\begin{array}{c}\text { Sistema Integrado } \\
\text { do Agreste / } \\
\text { Barragem Cajaíba }\end{array}$ \\
\hline Nome da capitação & $\begin{array}{c}\text { Jacarecica II, } \\
\text { Barragem da } \\
\text { Cajaíba, Barragem } \\
\text { da Ribeira }\end{array}$ & $\begin{array}{c}\text { Jacarecica II, } \\
\text { Barragem da } \\
\text { Cajaíba, Barragem } \\
\text { da Ribeira }\end{array}$ & $\begin{array}{c}\text { Jacarecica II, } \\
\text { Barragem da } \\
\text { Cajaíba, Barragem } \\
\text { da Ribeira }\end{array}$ & $\begin{array}{c}\text { Jacarecica II, } \\
\text { Barragem da } \\
\text { Cajaíba, Barragem } \\
\text { da Ribeira }\end{array}$ \\
\hline Tipo do manancial & Superficial & Superficial & Superficial & Superficial \\
\hline Quantidades de poços & & & & \\
\hline Operação em eta & \multicolumn{4}{|c|}{ Sim } \\
\hline Eta automatizada & \multicolumn{4}{|c|}{ Não } \\
\hline Regime de funcionamento & \multicolumn{4}{|c|}{8 Horas } \\
\hline Tipo de tratamento & \multicolumn{4}{|c|}{ Filtração Direta } \\
\hline Quantidades de filtros & \multicolumn{4}{|c|}{4} \\
\hline Vazão l/s & \multicolumn{4}{|c|}{720} \\
\hline Porte da eta & \multicolumn{4}{|c|}{ Grande } \\
\hline Quantidade de Reservatórios & 1 & & & 1 \\
\hline Tipo de reservatório & Elevado & & & Elevado \\
\hline $\begin{array}{l}\text { Capacidade de reservatório em } \\
\mathrm{m}^{3}\end{array}$ & 100 & & & 100 \\
\hline
\end{tabular}

Fonte: Supervisão Operacional UNCO, 2013. 
Ao analisamos os dados coletados em campo e junto à supervisão comercial, chegamos à conclusão que 6,45\% das ligações reais do município estão suprimidas, ou seja, com corte de fornecimento definitivo sem gerar talão de cobrança, ligações que necessitam serem constantemente fiscalizadas para que sejam evitadas as religações clandestinas.

Tabela 9-Características das Ligações do Município.

\begin{tabular}{|c|c|c|c|c|c|c|c|c|c|c|c|}
\hline \multirow{2}{*}{ Município/Povoados } & \multicolumn{2}{|c|}{ Residencial } & \multicolumn{2}{|c|}{ Comercial } & \multicolumn{2}{|c|}{ Industrial } & \multicolumn{2}{|c|}{ Público } & \multicolumn{3}{|c|}{ Ligações } \\
\hline & $\mathrm{CD} / \mathrm{HI}$ & $\mathrm{SD} / \mathrm{HI}$ & $\mathrm{CID} / \mathrm{H}$ & $\mathrm{SD} / \mathrm{HI}$ & $\mathrm{CD} / \mathrm{HI}$ & $\mathrm{SD} / \mathrm{HI}$ & $\mathrm{CID} / \mathrm{H}$ & $\mathrm{SD} / \mathrm{HI}$ & AASTIV & SI.UPR & RS EAI \\
\hline Itabaiana & 22.953 & 109 & 1.05 & 2 & 12 & - & 88 & 2 & 24.201 & 1.433 & 25.634 \\
\hline Pov. Cajaíba & 647 & 1 & 4 & - & - & - & 10 & - & 662 & 73 & 735 \\
\hline Pov. Queimadas & 162 & - & 5 & - & 5 & - & 4 & - & 176 & 234 & 410 \\
\hline Pov. Ribeira & 176 & - & - & - & - & - & 9 & - & 185 & 31 & 216 \\
\hline Pov. Rio das Pedras & 444 & - & 2 & - & 1 & - & 4 & - & 451 & 45 & 496 \\
\hline Pov. Terra Dura & 123 & - & 1 & - & - & - & 2 & - & 126 & 19 & 145 \\
\hline Pov. Carrilho & 199 & - & 2 & - & - & - & - & - & 201 & 18 & 219 \\
\hline Pov. Queimadinhas & 45 & - & - & - & 1 & - & 1 & - & 47 & 7 & 54 \\
\hline Pov. Prensa & 49 & - & - & - & - & - & 1 & - & 50 & 4 & 54 \\
\hline Pov. Vermelho & 41 & - & 1 & - & - & - & - & - & 42 & - & 42 \\
\hline Pov. Gandu I & 63 & - & - & - & - & - & - & - & 63 & 3 & 66 \\
\hline Pov. Gandu II & 69 & - & - & - & - & - & 1 & - & 70 & 3 & 73 \\
\hline Pov. Lagoa do Forno & 205 & - & - & - & - & - & 1 & - & 206 & 9 & 215 \\
\hline Pov. Taboca & 152 & - & - & - & - & - & - & - & 152 & 13 & 165 \\
\hline Pov. Dendenzeiro & 21 & - & - & - & - & - & - & - & 21 & - & 21 \\
\hline Pov. São José & 224 & - & - & - & - & - & 3 & - & 227 & 8 & 235 \\
\hline Pov. Forno & 100 & - & - & - & 3 & - & - & - & 103 & 4 & 107 \\
\hline Pov. Mangabeira & 186 & - & - & - & - & - & 3 & - & 189 & 9 & 198 \\
\hline Pov. Siebra & 22 & 1 & - & - & - & - & - & - & 23 & - & 23 \\
\hline Pov. Matapuã & 76 & 4 & 1 & - & - & - & 1 & - & 82 & 3 & 85 \\
\hline Pov. Cabeça do Russo & 95 & 4 & - & - & - & - & 1 & - & 100 & 4 & 104 \\
\hline Pov. Serra do Cágado & 8 & - & - & - & - & - & - & - & 8 & - & 8 \\
\hline Pov. Tabuleiro do Chico & 58 & 3 & - & - & - & - & - & - & 61 & - & 61 \\
\hline Pov. Tabuleiro da Telha & 21 & 2 & - & - & - & - & - & - & 23 & - & 23 \\
\hline Pov. Serra & 180 & - & - & - & - & 1 & - & - & 181 & 8 & 189 \\
\hline Pov. Lagamar & 201 & - & - & - & - & 1 & - & - & 202 & 3 & 205 \\
\hline Pov. Barro Preto & 189 & - & - & - & - & - & 1 & - & 190 & 3 & 193 \\
\hline Pov. Bula Cinza & 79 & - & - & - & - & - & - & - & 79 & 7 & 86 \\
\hline TOTAL & 26.788 & 124 & 1.051 & 2 & 22 & 2 & 130 & 2 & 28.121 & 1.941 & $\begin{array}{c}30.0 \\
62\end{array}$ \\
\hline
\end{tabular}

Fonte: Fonte: GSAN - Gestão de Sistema de Saneamento-DESO-UNCO-2013. 
As quatro mais recorrentes ocorrências de anomalias na micromedição desse sistema foram coletas, e após serem analisadas chegamos à conclusão que somadas elas correspondem a 16,77\% das ligações ativas, como mostra a tabela a seguir. Em face desta situação as informações coletadas nas leituras não revelam o real consumo, pois quando efetuada a leitura no hidrômetro é considerada a média dos consumos anteriores, gerando assim dados inconsistentes.

Tabela 10-Características das Anomalias das Ligações do Município.

\begin{tabular}{|c|c|c|c|c|c|c|c|c|}
\hline \multirow{2}{*}{ Município/Povoados } & \multicolumn{8}{|c|}{ Ocorrências } \\
\hline & Parado & $\%$ & Quebra. & $\%$ & Suado & $\%$ & Soter & $\%$ \\
\hline Itabaiana & 2.936 & 12,13 & 876 & 3,62 & 275 & 1,14 & 314 & 1,30 \\
\hline Pov. Cajaíba & 62 & 9,37 & 24 & 3,63 & 7 & 1,06 & 3 & 0,45 \\
\hline Pov. Queimadas & 48 & 27,27 & 6 & 3,41 & 6 & 3,41 & 5 & 2,84 \\
\hline Pov. Ribeira & 7 & 3,78 & 2 & 1,08 & - & 0,00 & 6 & 3,24 \\
\hline Pov. Rio das Pedras & 25 & 5,54 & 3 & 0,67 & - & 0,00 & 1 & 0,22 \\
\hline Pov. Terra Dura & 7 & 5,56 & 2 & 1,59 & 1 & 0,79 & - & 0,00 \\
\hline Pov. Carrilho & 7 & 3,48 & - & 0,00 & - & 0,00 & - & 0,00 \\
\hline Pov. Queimadinhas & 2 & 4,26 & - & 0,00 & - & 0,00 & - & 0,00 \\
\hline Pov. Prensa & 3 & 6,00 & - & 0,00 & - & 0,00 & - & 0,00 \\
\hline Pov. Vermelho & 2 & 4,76 & - & 0,00 & - & 0,00 & - & 0,00 \\
\hline Pov. Gandu I & 3 & 4,76 & - & 0,00 & - & 0,00 & - & 0,00 \\
\hline Pov. Gandu II & 9 & 12,86 & - & 0,00 & - & 0,00 & - & 0,00 \\
\hline Pov. Lagoa do Forno & 7 & 3,40 & - & 0,00 & - & 0,00 & - & 0,00 \\
\hline Pov. Taboca & 23 & 15,13 & - & 0,00 & - & 0,00 & - & 0,00 \\
\hline Pov. Dendenzeiro & - & 0,00 & - & 0,00 & - & 0,00 & - & 0,00 \\
\hline Pov. São José & 1 & 0,44 & 2 & 0,88 & - & 0,00 & - & 0,00 \\
\hline Pov. Forno & 12 & 11,65 & - & 0,00 & - & 0,00 & - & 0,00 \\
\hline Pov. Mangabeira & 9 & 4,76 & - & 0,00 & - & 0,00 & - & 0,00 \\
\hline Pov. Siebra & 1 & 4,35 & - & 0,00 & - & 0,00 & - & 0,00 \\
\hline Pov. Matapuã & 2 & 2,44 & - & 0,00 & - & 0,00 & - & 0,00 \\
\hline Pov. Cabeça do Russo & 4 & 4,00 & - & 0,00 & - & 0,00 & - & 0,00 \\
\hline Pov. Serra do Cágado & - & 0,00 & - & 0,00 & - & 0,00 & - & 0,00 \\
\hline Pov. Tabuleiro do Chico & - & 0,00 & - & 0,00 & - & 0,00 & - & 0,00 \\
\hline Pov. Tabuleiro da Telha & - & 0,00 & - & 0,00 & - & 0,00 & - & 0,00 \\
\hline Pov. Serra & 4 & 0,00 & - & 0,00 & - & 0,00 & - & 0,00 \\
\hline Pov. Lagamar & 5 & 0,00 & - & 0,00 & - & 0,00 & - & 0,00 \\
\hline Pov. Barro Preto & 3 & 0,00 & - & 0,00 & - & 0,00 & - & 0,00 \\
\hline Pov. Bula Cinza & - & 0,00 & - & 0,00 & - & 0,00 & - & 0,00 \\
\hline TOTAL & 3.182 & 11,32 & 915 & 3,25 & 289 & 1,03 & 329 & 1,17 \\
\hline
\end{tabular}

Fonte: Fonte: GSAN - Gestão de Sistema de Saneamento-DESO-UNCO-2013. 


\section{SISTEMA DE ABASTECIMENTO DO MUNICÍPIO DE MACAMBIRA}

A sede dispõe de sistema de abastecimento de água tratada, o município é atendido pelo Sistema do Agreste e não possui sistema de tratamento de esgoto lançando assim seus efluentes "in natura" na drenagem pluvial, valas, lagos ou rios próximos à sede municipal. Possui 05 (cinco) povoados atendidos pelo Sistema Agreste como mostra nas tabelas a seguir, com as quantidades e as características das ligações existentes no mesmo.

Tabela 11-Características dos Sistemas de Abastecimento no Município.

\begin{tabular}{|c|c|c|c|c|c|c|}
\hline NOME DO SISTEMA & Macambi ra & $\begin{array}{l}\text { Pov. Barro } \\
\text { Preto }\end{array}$ & $\begin{array}{l}\text { Pov. Lagoa } \\
\text { Seca }\end{array}$ & Pov. Tapera & $\begin{array}{c}\text { Pov. } \\
\text { Sobrado }\end{array}$ & $\begin{array}{c}\text { Pov. } \\
\text { Malhadinh a }\end{array}$ \\
\hline Nome da capitação & $\begin{array}{c}\text { Sistema } \\
\text { Integrado } \\
\text { do Agreste } \\
\text { Captação da } \\
\text { Cajaíba }\end{array}$ & $\begin{array}{c}\text { Sistema } \\
\text { Integrado } \\
\text { do Agreste } \\
\text { Captação } \\
\text { da Cajaíba }\end{array}$ & $\begin{array}{c}\text { Sistema } \\
\text { Integrado } \\
\text { do Agreste } \\
\text { Captação } \\
\text { da Cajaíba }\end{array}$ & $\begin{array}{c}\text { Sistema } \\
\text { Integrado } \\
\text { do Agreste } \\
\text { Captação da } \\
\text { Cajaíba }\end{array}$ & $\begin{array}{c}\text { Sistema } \\
\text { Integrado } \\
\text { do Agreste } \\
\text { Captação da } \\
\text { Cajaíba }\end{array}$ & $\begin{array}{c}\text { Sistema } \\
\text { Integrado do } \\
\text { Agreste } \\
\text { Captação da } \\
\text { Cajaíba }\end{array}$ \\
\hline Tipo do manancial & Superfici al & Superficial & Superficial & Superficial & Superficial & Superficial \\
\hline \multicolumn{7}{|l|}{ Quantidades de poços } \\
\hline Operação em eta & \multicolumn{6}{|c|}{ Não/Bombeamento em elevatória } \\
\hline \multicolumn{7}{|l|}{ Eta automatizada } \\
\hline $\begin{array}{l}\text { Regime de } \\
\text { funcionamento }\end{array}$ & \multicolumn{6}{|c|}{24 Horas } \\
\hline Tipo de tratamento & \multicolumn{6}{|c|}{ Simples Desinfecção } \\
\hline \multicolumn{7}{|l|}{ Quantidades de filtros } \\
\hline Vazão l/s & \multicolumn{6}{|c|}{72} \\
\hline Porte do sistema & \multicolumn{6}{|c|}{ Pequeno } \\
\hline $\begin{array}{l}\text { Quantidade de } \\
\text { Reservatórios }\end{array}$ & 2 & 1 & 0 & 0 & 0 & 0 \\
\hline Tipo de reservatório & $\begin{array}{c}01 \\
\text { Apoiado/ } \\
\text { 01 Elevado }\end{array}$ & Elevado & & & & \\
\hline $\begin{array}{l}\text { Capacidade de } \\
\text { reservatório em m }{ }^{3}\end{array}$ & $\begin{array}{c}700 \text { e } 150 \\
\text { m3 }\end{array}$ & 100 & & & & \\
\hline
\end{tabular}

Ao analisamos os dados coletados em campo e junto à supervisão comercial, chegamos à conclusão que $10,92 \%$ das ligações reais do município estão suprimidas, ou seja, com corte de fornecimento definitivo sem gerar talão de cobrança, ligações que necessitam serem constantemente fiscalizadas pra que sejam evitadas as religações clandestinas.

Tabela 12-Características das Ligações do Município.

\begin{tabular}{|c|c|c|c|c|c|c|c|c|c|c|c|}
\hline \multirow[t]{2}{*}{$\begin{array}{c}\text { Município/ } \\
\text { Povoados }\end{array}$} & \multicolumn{2}{|c|}{ Residencial } & \multicolumn{2}{|c|}{ Comercial } & \multicolumn{2}{|c|}{ Industrial } & \multicolumn{2}{|c|}{ Público } & \multicolumn{3}{|c|}{ Ligações } \\
\hline & $\mathrm{CID} / \mathrm{H}$ & S/DHI & $\mathrm{CID} / \mathrm{H}$ & SI/DH & ID/H & S/DHI & ID/H & SI/DH & ASTIV & RUI.P & AEIS \\
\hline Macambira & 1.092 & - & 19 & - & 1 & - & 29 & - & 1.141 & 105 & 1.246 \\
\hline Pov. Barro Preto & 180 & - & - & - & - & - & 2 & - & 182 & 44 & 226 \\
\hline Pov. Lagoa Seca & 53 & - & - & - & - & - & 2 & - & 55 & 12 & 67 \\
\hline Pov. Tapera & 88 & - & - & - & - & - & - & - & 88 & 12 & 100 \\
\hline Pov. Sobrado & 112 & - & - & - & - & - & - & & 112 & 19 & 131 \\
\hline Pov. Malhadinha & 28 & - & - & - & - & - & - & - & 28 & 5 & 33 \\
\hline TOTAL & 1.553 & - & 19 & - & 1 & - & 33 & - & 1.66 & 197 & $\begin{array}{l}1.8 \\
03\end{array}$ \\
\hline
\end{tabular}

Fonte: Fonte: GSAN - Gestão de Sistema de Saneamento-DESO-UNCO-2013.

As quatro mais recorrentes ocorrências de anomalias na micromedição desse sistema foram coletas, e após serem analisadas chegamos à conclusão que somadas elas correspondem a 9,33\% das ligações ativas, como mostra a tabela a seguir. Em face desta situação as informações coletadas nas leituras não revelam o real consumo, pois quando efetuada a leitura no hidrômetro é considerada a média dos consumos anteriores, gerando assim dados inconsistentes. 
Tabela 13-Características das Anomalias das Ligações do Município.

\begin{tabular}{|c|c|c|c|c|c|c|c|c|}
\hline \multirow{2}{*}{ MUNICÍPIO/POVOADOS } & \multicolumn{8}{|c|}{ OCORRÊNCIAS } \\
\hline & PARADO & $\%$ & QUEBRA. & $\%$ & SUADO & $\%$ & SOTER & $\%$ \\
\hline Macambira & 94 & 8,24 & 14 & 1,23 & 8 & 0,70 & 4 & 0,35 \\
\hline Pov. Barro Preto & 14 & 7,69 & - & 0,00 & 1 & 0,55 & - & 0,00 \\
\hline Pov. Lagoa Seca & 4 & 7,27 & - & 0,00 & - & 0,00 & - & 0,00 \\
\hline Pov. Tapera & 2 & 2,27 & - & 0,00 & - & 0,00 & 1 & 1,14 \\
\hline Pov. Sobrado & 5 & 4,46 & 1 & 0,89 & 1 & 0,89 & 1 & 0,89 \\
\hline Pov. Malhadinha & - & 0,00 & - & 0,00 & - & 0,00 & - & 0,00 \\
\hline TOTAL & 119 & 7,41 & 15 & 0,93 & 10 & 0,62 & 6 & 0,37 \\
\hline
\end{tabular}

\section{SISTEMA DE ABASTECIMENTO DO MUNICÍPIO DE RIBEIRÓPOLIS}

A sede dispõe de sistema de abastecimento de água tratada, o município é atendido por um Sistema do Independente e não possui sistema de tratamento de esgoto lançando assim seus efluentes "in natura" na drenagem pluvial, valas, lagos ou rios próximos à sede municipal. Possui 01 (um) povoado atendido por um Sistema Independente como mostra na tabela abaixo, que apresenta as características dos sistemas, as quantidades e as características das ligações existentes nos mesmos.

Tabela 14-Características dos Sistemas de Abastecimento no Município.

\begin{tabular}{l|c|c}
\multicolumn{1}{c}{ LOCALIDADES } & Ribeirópolis & Pov. Serra do Machado \\
Nome do sistema & Independente & Independente \\
\hline Nome da capitação & Poços & Subços \\
\hline Tipo do manancial & 8 & 2 \\
\hline Quantidades de poços & Não & Não \\
\hline Operação em eta & Bombeamento 24 horas & Bombeamento 24 horas \\
\hline Eta automatizada & Simples Desinfecção & Simples Desinfecção \\
\hline Regime de funcionamento da eta & 108 & \\
\hline Tipo de tratamento & & 8 \\
\hline Quantidades de filtros & 1 & \\
\hline Vazão l/s & & \\
\hline Porte da eta & Elevado & Elevado \\
\hline Quantidade de reservatórios & 100 & 50 \\
\hline Tipo de reservatório & & \\
\hline Capacidade de reservatório em $\mathrm{m}^{3}$ & & \\
\hline
\end{tabular}

Fonte: Supervisão Operacional UNCO, 2013.

Ao analisamos os dados coletados em campo e junto à supervisão comercial, chegamos à conclusão que 8,38\% das ligações reais do município estão suprimidas, ou seja, com corte de fornecimento definitivo sem gerar talão de cobrança, ligações que necessitam serem constantemente fiscalizadas para que sejam evitadas as religações clandestinas.

Tabela 15-Características das Ligações do Município.

\begin{tabular}{|c|c|c|c|c|c|c|c|c|c|c|c|}
\hline \multirow[t]{2}{*}{ Município/ Povoados } & \multicolumn{2}{|c|}{ Residencial } & \multicolumn{2}{|c|}{ Comercial } & \multicolumn{2}{|c|}{ Industrial } & \multicolumn{2}{|c|}{ Público } & \multicolumn{3}{|c|}{ Ligações } \\
\hline & $\mathrm{CID} / \mathrm{H}$ & $\mathrm{SD} / \mathrm{HI}$ & $\mathrm{CID} / \mathrm{H}$ & SI/DH & ID/H & S/DHI & $\mathrm{ID} / \mathrm{H}$ & ID/H & ASTIV & RUI.P & AEIS \\
\hline Ribeirópolis & 4.444 & 11 & 68 & - & 1 & - & 33 & - & 4.557 & 400 & 4.957 \\
\hline Pov. Serra do Machado & 307 & - & 3 & - & - & - & 3 & 1 & 314 & 46 & 360 \\
\hline TOTAL & 4.751 & 11 & 71 & - & 1 & - & 36 & 1 & 4.871 & 446 & 5.317 \\
\hline
\end{tabular}

Fonte: Fonte: GSAN - Gestão de Sistema de Saneamento-DESO-UNCO-2013.

As quatro mais recorrentes ocorrências de anomalias na micromedição desse sistema foram coletas, e após serem analisadas chegamos à conclusão que somadas elas correspondem a 15,91\% das ligações ativas, como mostra a tabela a seguir. Em face desta situação as informações coletadas nas leituras não revelam o real consumo, pois quando efetuada a leitura no hidrômetro é considerada a média dos consumos anteriores, gerando assim dados inconsistentes. 
Tabela 16-Características das Anomalias das Ligações do Município.

\begin{tabular}{|c|c|c|c|c|c|c|c|c|}
\hline \multirow{2}{*}{ Município/ Povoados } & \multicolumn{8}{|c|}{ Ocorrências } \\
\hline & POARAD & $\%$ & QUEBRA & $\%$ & SUADO & $\%$ & SROTE & $\%$ \\
\hline Ribeirópolis & 495 & 10,86 & 135 & 2,96 & 85 & 1,87 & 28 & 0,61 \\
\hline Pov. Serra do Machado & 31 & 9,87 & - & 0,00 & 1 & 0,32 & - & 0,00 \\
\hline TOTAL & 526 & 10,80 & 135 & 2,77 & 86 & 1,77 & 28 & 0,57 \\
\hline
\end{tabular}

Fonte: Fonte: GSAN - Gestão de Sistema de Saneamento-DESO-UNCO-2013.

\section{SISTEMA DE ABASTECIMENTO DO MUNICÍPIO DE SÃO DOMINGOS}

A sede dispõe de sistema de abastecimento de água tratada, o município é atendido pelo Sistema do Agreste e não possui sistema de tratamento de esgoto lançando assim seus efluentes "in natura" na drenagem pluvial, valas, lagos ou rios próximos à sede municipal. Possui 01 (um) povoado atendido pelo Sistema Agreste como mostra nas tabelas abaixo, que apresentam as características dos sistemas, as quantidades e as características das ligações existentes nos mesmos.

Tabela 17-Características dos Sistemas de Abastecimento no Município.

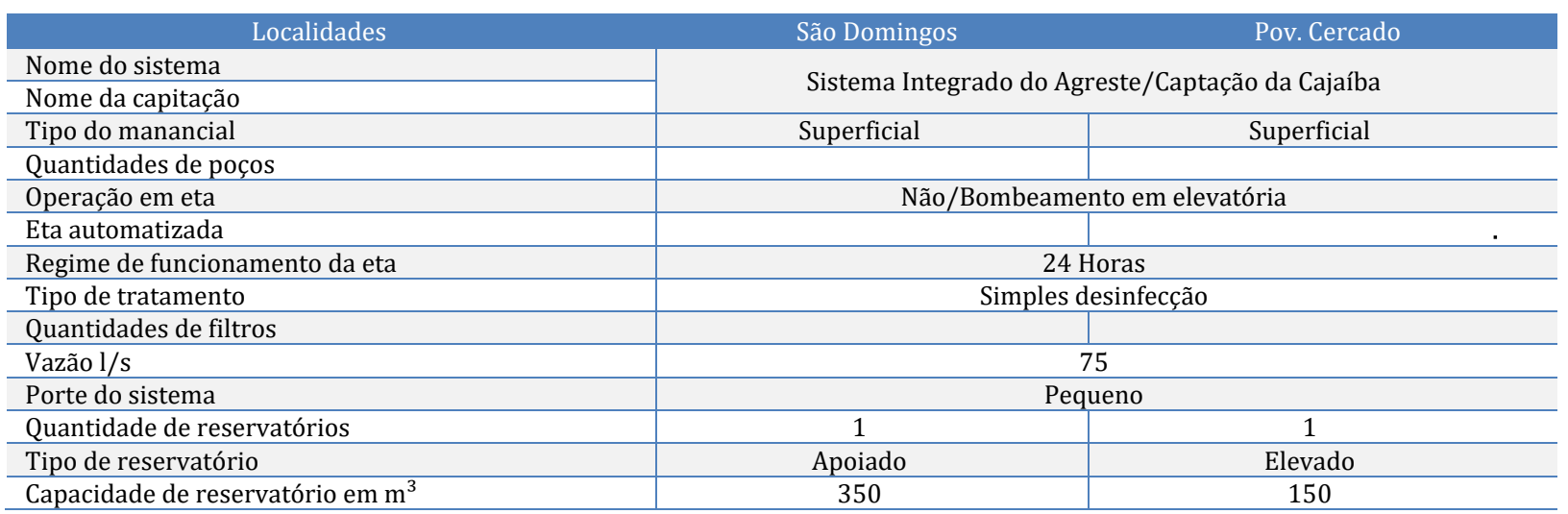

Fonte: Supervisão Operacional UNCO, 2013.

Ao analisamos os dados coletados em campo e junto à supervisão comercial, chegamos à conclusão que $13,65 \%$ das ligações reais do município estão suprimidas, ou seja, com corte de fornecimento definitivo sem gerar talão de cobrança, ligações que necessitam serem constantemente fiscalizadas para que sejam evitadas as religações clandestinas.

Tabela 18-Características das Ligações do Município.

\begin{tabular}{|c|c|c|c|c|c|c|c|c|c|c|c|}
\hline \multirow{2}{*}{ Município/ Povoados } & \multicolumn{2}{|c|}{ Residenc ial } & \multicolumn{2}{|c|}{ Comerc ial } & \multicolumn{2}{|c|}{ Industr ial } & \multicolumn{2}{|c|}{ Públic o } & \multicolumn{3}{|c|}{ Ligações } \\
\hline & $\mathrm{CID} / \mathrm{H}$ & S/DHI & $\mathrm{CID} / \mathrm{H}$ & $\mathrm{SI} / \mathrm{DH}$ & $\mathrm{CI} / \mathrm{DH}$ & S/DHI & $\mathrm{ID} / \mathrm{H}$ & SI/DH & ASTIV & RUI.P & AEIS \\
\hline São Domingos & $\begin{array}{c}1.98 \\
0\end{array}$ & r & 37 & F & $f_{1}$ & 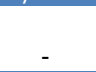 & 25 & 皮 & $\begin{array}{c}2.04 \\
2\end{array}$ & 322 & $\begin{array}{l}2.3 \\
64\end{array}$ \\
\hline Pov. Cercado & 114 & - & - & - & - & - & - & - & 114 & 19 & 133 \\
\hline Total & $\begin{array}{c}2.09 \\
4\end{array}$ & - & 37 & - & - & - & 25 & - & $\begin{array}{c}2.15 \\
6\end{array}$ & 341 & $\begin{array}{l}2.4 \\
97\end{array}$ \\
\hline
\end{tabular}

Fonte: GSAN - Gestão de Sistema de Saneamento-DESO-UNCO-2013.

As quatro mais recorrentes ocorrências de anomalias na micromedição desse sistema foram coletas, e após serem analisadas chegamos à conclusão que somadas elas correspondem a 2,78\% das ligações ativas, como mostra a tabela a seguir. Em face desta situação as informações coletadas nas leituras não revelam o real consumo, pois quando efetuada a leitura no hidrômetro é considerada a média dos consumos anteriores, gerando assim dados inconsistentes. 
Tabela 19 - Características das Anomalias das Ligações do Município.

\begin{tabular}{|c|c|c|c|c|c|c|c|c|}
\hline \multirow{2}{*}{ MUNICÍPIO/POVOADOS } & \multicolumn{6}{|c|}{ OCORRÊNCIAS } & \multirow[b]{2}{*}{ SROTE } & \multirow[b]{2}{*}{$\%$} \\
\hline & POARAD & $\%$ & QUEBRA & $\%$ & SUADO & $\%$ & & \\
\hline São Domingos & 45 & 2,20 & 5 & 0,24 & 3 & 0,15 & 5 & 0,24 \\
\hline Pov. Cercado & 1 & 0,88 & - & 0,00 & 1 & 0,88 & - & 0,00 \\
\hline TOTAL & 46 & 2,13 & 5 & 0,23 & 4 & 0,19 & 5 & 0,23 \\
\hline
\end{tabular}

Fonte: Fonte: GSAN - Gestão de Sistema de Saneamento-DESO-UNCO-2013.

\section{CONSIDERAÇÕES FINAIS}

Considerando as análises feitas neste estudo podemos afirmar que foram encontrados nos municípios analisados índices no tocante:

As ligações suprimidas variam de 6,45\% a 16,36\% das ligações reais, nas localidades analisadas fator este que requer sempre recurso da empresa, pois precisam ser constantemente fiscalizadas face às religações clandestinas que não tem controle já que a empresa não fatura, não arrecada e alem de tudo oferta uma grande quantidade, pois os consumidos não se preocupam com os esperdícios;

As anomalias na micromedição variam de 2,78\% a 16,77\% das ligações ativas, como mostra na tabela a baixo, obrigando assim a empresa a faturar e tentar arrecadar pela média consumida elevando a oferta, pois deixa o consumidor despreocupado já que o mesmo sabe que independente da quantidade consumida só pagará à média.

Tabela 20-Características das Anomalias das Ligações dos Municípios.

\begin{tabular}{|c|c|c|c|c|c|c|c|c|c|}
\hline \multirow{2}{*}{ Sistema de abastecimento } & \multicolumn{8}{|c|}{ Ocorrênc ias } & \multirow{2}{*}{ TOTA L } \\
\hline & Parado & $\%$ & Quebrado & $\%$ & Suado & $\%$ & Soterrado & $\%$ & \\
\hline Areia Branca/Povoados & 404 & 10,39 & 95 & 2,44 & 30 & 0,77 & 23 & 0,59 & 14,19 \\
\hline $\begin{array}{l}\text { Campo do } \\
\text { Brito/Povoados }\end{array}$ & 224 & 5,09 & 14 & 0,32 & 17 & 0,39 & 7 & 0,16 & 5,96 \\
\hline Itabaiana/Povoados & 3.182 & 11,32 & 915 & 3,25 & 289 & 1,03 & 329 & 1,17 & 16,77 \\
\hline Macambira/Povoados & 119 & 7,41 & 15 & 0,93 & 10 & 0,62 & 6 & 0,37 & 9,33 \\
\hline Ribeirópolis/Povoados & 526 & 10,80 & 135 & 2,77 & 86 & 1,77 & 28 & 0,57 & 15,91 \\
\hline $\begin{array}{l}\text { São } \\
\text { Domingos/Povoados }\end{array}$ & 46 & 2,13 & 5 & 0,23 & 4 & 0,19 & 5 & 0,23 & 2,78 \\
\hline
\end{tabular}

Fonte: GSAN - Gestão de Sistema de Saneamento-DESO-UNCO-2013.

3-A grande quantidade de hidrômetros que estão com as suas idades de operação fora dos padrões da ABNT/INMETRO, fator que compromete as informações com precisão do que foi distribuído, faturado e do que será arrecadado, além de não ajudar a indicar melhor os trechos onde se encontram os desperdícios.

Com o que foi encontrado faz-se necessário implantar políticas no sistema de macromedição, setorização, micromedição, correção das irregularidades nos ramais prediais, substituição de hidrômetros que apresentam anomalias funcionais e melhorar o controle operacional do sistema distribuidor.

Promover a redução de perdas além de fatores econômicos existe um fator ambiental importantíssimo que é a redução da quantidade de água captada dos mananciais já que hoje o índice de perdas é muito grande. Não é porque hoje o recurso é abundante que se postergará a adoção de medidas que visem seu uso sustentável. É no próprio ambiente de abundância que a gestão estruturada deve iniciar-se para agir de forma preventiva e não corretiva, é imprescindível integrar o planejamento das atividades das companhias estaduais e municipais de saneamento com os planos de gestão das bacias hidrográficas, associados ao controle da poluição de corpos receptores e de efluentes.

A gestão das águas deve ser integrada, participativa e descentralizada onde o gestor público compartilha com todos os cidadãos a responsabilidade de garantir água em quantidade e qualidade suficientes. A cultura predominante do desperdício de água se contrapõe aos programas e propostas de gestão sustentável dos recursos hídricos, apesar dos inúmeros apelos direcionados para este propósito.

Assim, diante desse cenário e considerando todas as abordagens ao longo deste artigo, fica evidente que a questão da água, está diretamente relacionada e dependente de dois aspectos básicos, a cultura do 
desperdício embasada na falsa premissa de que temos água em abundância e a ausência de políticas que discipline e controle de forma mais enérgica, o consumo.

\section{REFERÊNCIAS}

[1] ABES-Associação Brasileira de Engenharia Sanitária e Ambiental. Combate ao Desperdício de Energia e Água em Saneamento Ambiental. Programa do 10을 Curso, Rio de Janeiro, 2006.

[2] Chama NeTO, P. J. Ramal Predial de Água em Polietileno. Curso de Combate ao Desperdício de Água e Energia Elétrica. Sabesp/Eletrobrás. São Paulo, 2006.

[3] Companhia de Saneamento de Sergipe (DESO). Unidade de Negócios Centro- Oeste. Planilha de Características das Ligações da Unidade. Supervisão Comercial. Itabaiana, 2013.

[4] Companhia de Saneamento de Sergipe (DESO). Unidade de Negócios Centro- Oeste. Planilha de Características dos Sistemas Operacionais da Unidade. Supervisão Operacional. Itabaiana, 2013.

[5] MIERZWA, J. C.; HESPANHOL, I. Água na Indústria: Uso Racional e Reuso. São Paulo: Oficina de Textos, 2005.

[6] MIRANDA, E. C. Gerenciamento de Perdas de Água. Capítulo 17. In: Abastecimento de Água para Consumo Humano. Léo Heller e Valter Lúcio de Pádua (Organizadores). Belo Horizonte: Editora UFMG, 2006.

[7] SNIS-Serviços de Água e Esgotos. Parte 1 - Texto. Visão Geral de Prestação de Serviços. Sistema Nacional de Informações sobre Saneamento. Ministério das Cidades, Brasília, 2005.

[8] TARDELLI FILHO, J. Controle e Redução de Perdas. Capítulo 10. In: Abastecimento de Água. Departamento de Engenharia Hidráulica e Sanitária da Escola Politécnica da Universidade de São Paulo. São Paulo, 2004. 


\title{
CAPÍTULO 06 Avaliação do desempenho de sistemas de irrigação em lotes do perímetro irrigado Jacarecica I
}

\author{
Valbério Paolilo dos Santos \\ Ariovaldo Antonio Tadeu Lucas
}

\section{INTRODUÇÃO}

As fontes hídricas são mal distribuídas na superfície do planeta, em algumas áreas, as retiradas são tão elevadas em comparação com a recarga, que a disponibilidade superficial de água está sendo reduzida e os recursos subterrâneos rapidamente esgotados, sendo, portanto, de fundamental importância o uso eficiente dos recursos hídricos, principalmente pela agricultura irrigada, seu principal consumidor (Medeiros et al.,2003).

Dentre as diversas atividades que exploram os recursos água e solo, a agricultura se destaca, pois além de demandar grande quantidade de água, aproximadamente $70 \%$ da água doce do planeta, muitas de suas práticas preconizam o uso excessivo de produtos que podem contaminar o solo e as próprias fontes de água (Carvalho \& Oliveira, 2012).

A irrigação é uma técnica essencial para a produção de alimentos no mundo, pois é possível se ter uma escala de produção, com oferta de alimentos em época que não seria possível em agricultura de sequeiro, principalmente tratando-se da região Nordeste que apresenta elevadas taxas evaporativas e variações anuais de precipitação. Além disso, com a introdução da irrigação, ocorre um incremento de áreas que passam a ser produtivas e que sem a irrigação isto não seria possível.

Com o crescimento da populacional há uma preocupação em aumentar a produção de alimentos e de outros produtos agrícolas. Sendo que o aumento daprodutividade média das culturas, ainda tem potencial de crescimento e pode ser facilmente superada, utilizando-se tecnologia adequada.Além do que a abertura de novas fronteiras agrícolas gera sérios impactos ambientais, principalmente pelo desmatamento de florestas,como o que ocorreu no passado de forma intensa.

A irrigação é destacadamente uma das práticas agrícolas que possibilita maior impacto no aumento da produtividade agrícola, viabilizando, inclusive, a produção em regiões com baixa disponibilidade hídrica. Apesar disso a irrigação ainda é realizada de forma inadequada, geralmente com grandes desperdícios de água. Estima-se que, de toda a água captada para fins de irrigação, apenas $50 \%$ seja utilizada pelas plantas e em sistemas de irrigação por superfície, as perdas podem ultrapassar 75\% (Sousa et al.,2011).

Porémnem toda água perdida é efetivamente desperdiçada, levando a definição de usos benéficos e não benéficos da água no contexto da agricultura irrigada, bem como das definições de uso consuntivo e não consuntivo da água (Burt et al., 1997).No entanto, essas perdas não devem ser mais aceitas, pois atualmente a demanda por água é muito grande, sendo muitas vezes motivo de conflito entre os usuários, além do fato da água ser extremamente limitante em algumas regiões do país,situação que se agrava ainda mais no período de estação seca e em condições de precipitações pluviométricas abaixo damédia.

Segundo Oliveira et al (2010) 40\% da produção mundial de alimentos são oriundas de áreas irrigadas. No entanto deve-se considerar que a irrigação consome muitaágua, mas este fato pode ser minimizadoe melhorado com a implantação de sistemas mais eficientes, associado à prática de manejo de água nas áreas irrigadas.

Sistemasde irrigação são planejados e implantados com o propósito de fornecer às culturas a água necessária ao seu ótimo desenvolvimento e produção, adotando-se medidas capazes de proporcionar um manejo racional e de maneira eficiente da irrigação (Bernardo et al., 2005). 
Os sistemas de irrigação localizados são mais eficientes e consequentemente se manejados de forma correta propiciam reduções no consumo de água para a irrigação, contudo é necessário serem mais difundidos junto aos agricultores. Os sistemas de irrigação localizados são muitosutilizados onde a água é fator limitante, tanto pelo seu custo quanto pela sua quantidade e qualidade, devendo os agricultores maximizar a produtividade por milímetro de água aplicado (Oliveira, 1999).

A irrigação muitas vezes é utilizada de forma desordenada sem um controle da lâmina de irrigação, e que em geral, a aplicação de água é realizada em excesso, ocasionando perdas de água e nutrientes no solo por erosão ou lixiviação, contribuindo para uma redução da fertilidade natural dos solos. É necessário conscientizar os irrigantes que o uso da água para irrigação deve ser feito de forma racional, a fim de evitar desperdícios e contaminação dos mananciais, garantindo para a atividade sustentabilidade econômica e ambiental.

O presente estudo teve como objetivo avaliar sistemas de irrigação por aspersão e o manejo adotado pelos agricultores do PerímetroIrrigado Jacarecica I, localizado na região agreste do Estado de Sergipe, utilizando-se os parâmetros de uniformidade, eficiência de distribuição de água e lâmina aplicada.

\section{MATERIAL EMÉTODOS}

\subsection{PERÍMETRO IRRIGADO JACARECICA I}

O Perímetro Irrigado Jacarecica I está localizado no município de Itabaiana, região agreste do Estado de Sergipe, distante 65,0 Km de Aracaju, com clima classificado tipo megatérmico seco e subúmido, temperatura média anual de $24,7^{\circ} \mathrm{C}$, precipitação pluviométrica média no ano de $858,5 \mathrm{~mm}$ e período chuvoso de março a agosto.

0 perímetro é constituído de 130 lotes com área média de 2,0 ha, dos quais 4 lotes foram reservados para a construção da sede do perímetro, do escritório da Cohidro e construção de uma agrovila para os 124 irrigantes selecionados.A área irrigável é de 252,0 ha, com 02 lotes destinados a pesquisa agrícola e 124 lotes atendendo a famílias de agricultores que foram assentados.

Toda a área do perímetro está contida na sub-bacia do rio Jacarecica, afluente a margem direita do rio Sergipe. A captação de água é feita na barragem com $20 \mathrm{~m}$ de altura máxima e $420 \mathrm{~m}$ de comprimento. A área inundada atinge 155,4 ha,com um volume de acumulação em torno de 4.700.000,0 metros cúbicos deágua.

Os irrigantes cultivam exclusivamente olerícolas com destaque para as culturas da batata-doce, quiabo, amendoim, coentro, pepino, maxixe,alface, milho e pepino.Observou-se que a batata-doce é a cultura predominante, segundo estimativa da Cohidro, $75 \%$ da área irrigada se encontram com a referida cultura. Dado que se assemelha ao obtido por Lopes (1997) que em teste de campo realizado em 1994 registrou como principais culturas a batata-doce e o amendoim, com destaque para a batata-doce, ocupando aproximadamente $85 \%$ da área.

O sistema de irrigação é por aspersão semifixo e iniciou o seufuncionamento em 1987, ano em que foi concluído o projeto executivo. Masapesar do projeto ser concebido para sistema de irrigação por aspersão semifixo, atualmente existe vinte três lotes que fizeram alteração, utilizando sistema localizado de microaspersão e sistema de tubo perfurado a laser. Dos cento e vinte quatro lotes de irrigantes, $81 \%$ permanecem com o sistema por aspersão semifixo, quinze lotes utilizam sistema localizado de microaspersão, correspondendo a $12 \%$ dos lotes e oito lotes estão utilizando sistema de irrigação por tubo perfurado a laser.

Entretanto, em consulta ao projeto do perímetro irrigado Jacarecica I, realizada no escritório central da Cohidro, verificou-se que o projeto inicial foi concebido para funcionar com quatro aspersores por lateral, espaçados de $12 \times 18 \mathrm{~m}$, sendo o aspersor com as seguintes características operacionais, bocal: 5,6 x 2,5 mm; pressão de serviço: 30 m.c.a.; vazão: 2,3 m3.h-1 e raio de alcance: 16,5 m.Em visitas realizadas ao perímetro, constatou-se junto aos técnicos da Cohidro que atualmente, dentre os lotes que ainda utilizam o sistema de aspersão semiportátil, nenhum utiliza o espaçamento de aspersores projetado, utilizando os espaçamentos $6 \times 12 \mathrm{~m}$ e $12 \times 12 \mathrm{~m}$ e que os que utilizam o espaçamento $6 \times 12$ $\mathrm{m}$ a linha lateral funciona com seisaspersores.

Nos lotes estudados foram encontrados dois tipos de aspersores, comsuas características operacionais descritas na Tabela 1. 
Tabela 1. Características operacionais dos aspersores utilizados pelos irrigantes.

\begin{tabular}{|c|c|c|c|c|c|}
\hline Diâmetro & Pressão & Vazão & Diâmetro de & Espaçamento & Intensidade \\
\hline \multicolumn{4}{|c|}{ Nominal do bocal de 3-1 alcance(m) } & entre aspersores & de aplicação \\
\hline \multicolumn{6}{|c|}{ Serviço (m . h ) } \\
\hline$(\mathrm{mm})$ & (m.c.a.) & & & $(\mathrm{m})$ & $(\mathrm{mm})$ \\
\hline $4,0 \times 3,0$ & 25 & 1,489 & 30,0 & $6,0 \times 12,0$ & 20,67 \\
\hline $5,0 \times 4,6$ & 25 & 2,43 & 31,8 & $12 \times 12$ & 16,88 \\
\hline
\end{tabular}

Considerando o tempo em que o sistema foi implantado e as diversas alterações realizadas pelos agricultores irrigantes, do projeto original, uma avaliação das condições em que se encontram os equipamentos e os materiais, com o intuito de analisar os reflexos das condições dos mesmos na uniformidade da irrigação é de extrema importância para verificação da necessidade de mudanças para melhorias.

\subsection{AVALIAÇÃO DO SISTEMA DE IRRIGAÇÃO}

Foram escolhidos para este estudo, três lotes de agricultores que utilizam sistema de irrigação por aspersão, os quais foram avaliados em condições usuais de operação, refletindo assim as condições reais de operação do sistema e a qualidade da irrigação praticada pelos irrigantes.

Para a avaliação da uniformidade de distribuição foram realizados testes em campo, utilizando-se coletores plásticos com capacidade para $400 \mathrm{~mL}$, colocados verticalmente sobre o solo, dispostos, obedecendo ao espaçamento de $3 \times 3 \mathrm{~m}$, conforme Figura 1. Cada teste teve a duração de trinta minutos que ao final, utilizando-se de provetas, foram medidos os volumes de água em cada coletor, sendo posteriormente convertido o volume medido em $\mathrm{mL}$ de cada coletor paramm.

A uniformidade de distribuição da água em áreas irrigadas influencia diretamente o manejo, a qualidade, a eficiência e o custo da irrigação, assim como o desempenho da cultura no campo. Uma reduzida uniformidade de distribuição da água faz com que determinadas plantas irrigadas pelo sistema recebam mais água do que outras resultando em desenvolvimento desuniforme da cultura (Pereira et al., 2011).

Para avaliação do desempenho dos sistemas de irrigação, foramutilizadas as equações para os cálculos dos índices de uniformidade eeficiência que se encontram descritas abaixo.

Coeficiente de Uniformidade de Christiansen(CUC)

$$
C U C=100\left[1-\frac{\sum_{i=1}^{N}(L i-L m)}{N L m}\right]
$$

$\mathrm{Li}=$ lâmina coletada em cada coletor $(\mathrm{mm}) \mathrm{Lm}=$ média das lâminas coletadas (mm)

$\mathrm{N}=$ número de coletores

Coeficiente de Uniformidade de Distribuição(CUD)

$$
C U D=100\left(\frac{L_{25}}{L_{m c}}\right)
$$


L25 = média equivalente aos $25 \%$ menores valores coletados $(\mathrm{mm})$ Lmc = média das lâminas coletadas

\subsection{LINHA DE DISTRIBUIÇÃO}

Para os aspersores selecionados foram coletados também dados de pressão e vazão. As medidas de pressão de serviço foram determinadas diretamente no bocal do aspersor, por meio de manômetro de glicerina, acoplado a um tubo de Pitot. E para a medição da vazão, utilizou-se um tubo coletor que conduziu toda a água que seria aspergida para um recipiente de volume conhecido, onde, simultaneamente, mediu-se o tempo para completar esse volume.

Foram utilizados dados da estação meteorológica instalada no perímetro irrigado, na área do escritório da Cohidro.

\section{RESULTADOS E DISCUSSÕES}

A pressão de serviço medida nos aspersores dos lotes estudados em condições normais de funcionamento se encontra abaixo da preconizada no projeto técnico original que é de 30,0 m.c.a., com variação entre os lotes, conforme Tabela 2 que contém os resultados das médias da pressão de serviço determinada do aspersor avaliado. No entanto, deve-se considerar o desgaste do sistema de bombeamento já que o perímetro irrigado teve seu início de funcionamento em 1987 e queaté o momento deste estudo o perímetro continua operando com o mesmo sistema. Observou-se que no lote 1P51 a pressão de serviço encontrada está mais próxima da estabelecida no projeto, enquanto que a dos lotes 1P32 e 3P05 estão bem mais baixas da projetada.

0 resultado da vazão nos aspersores variou bastante entre os lotes estudados e nos três a vazão está abaixo da projetada que é de $2,3 \mathrm{~m} 3$. h-1. Além dos fatos acima relatados, considerando o desgaste natural do sistema de bombeamento, destaca-se que a observação de diversos pontos de vazamentos, resultando em desperdício de água e redução na vazão dosaspersores, podendo ocasionar aumento no tempo de irrigação ou aplicaçãode água inferior à necessidadeda cultura, comprometendo bastante o manejo da irrigação o que vem a afetar o desenvolvimento e a produção das culturas.

Os valores médios de vazão do aspersor avaliado, também são, inferiores ao projetado (Tabela 2), certamente estão relacionados aos problemas citados anteriormente, pois são inúmeros os pontosde vazamentos e o perímetro está operando com a mesma tubulaçãoque é de aço zincado, desde a sua implantação. Consequentemente está se encontra em estado ruim e a situação se agrava pelo fato do sistema de irrigação ser semiportátil, onde as linhas laterais são móveis, com a tubulação de engate rápido que se encontra com as borrachas de vedação bastantecomprometidas.

Tabela 2. Pressão de serviço e vazão dos aspersores avaliados nos respectivos lotes do perímetro irrigado Jacarecica I.

\begin{tabular}{c|c|c} 
LOTES & PRESSÃO (mca) & VAZÃO (m3.h-1) \\
\hline 1P51 & 25,5 & 1,584 \\
\hline 1 P32 & 19,4 & 0,886 \\
\hline 3P05 & 15,3 & 0,908 \\
\hline
\end{tabular}


Nas Figuras 2,3 e 4 se encontram os resultados das lâminas coletadas, após sobreposição, dos três lotes estudados.

\begin{tabular}{|c|c|c|c|}
\hline $\mathbf{X} 3,21$ & 10,53 & 11,48 & 13,36 \\
\hline 10,85 & 8,57 & 12,26 & 13,28 \\
\hline 9,43 & 11,47 & 12,42 & 9,91 \\
\hline$X$ & 8,02 & 8,97 & 7,86 \\
\hline 8,31 & 8,33 & 10,85 & 7,86 \\
\hline 8,80 & 7,55 & 9,59 & 7,24 \\
\hline 8,09 & $X$ \\
\hline
\end{tabular}

Lote $1 \mathrm{P} 32(6 \mathrm{~m} \times 12 \mathrm{~m})$

Lote $1 \mathrm{P} 51(12 \mathrm{~m} \times 12 \mathrm{~m})$

Figura 2. Resultados das lâminas de irrigação (mm) coletadas nos lotes 1P51 e1P32, após a sobreposição.

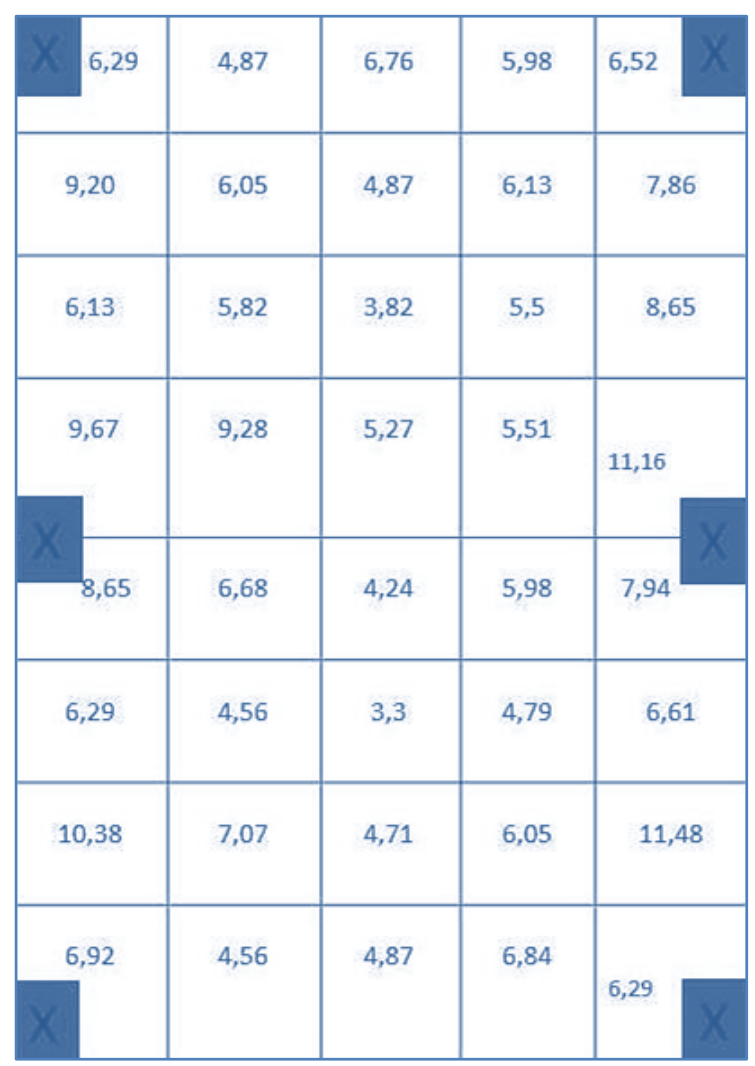

Lote 3P05 (6 m x $12 \mathrm{~m})$ 
Figura3. Resultados das lâminas de irrigação (mm) coletadas no lote 3P05, após a sobreposição

\begin{tabular}{|c|c|c|c|}
\hline 7,47 & 10,93 & 12,26 & 7,63 \\
\hline 7,63 & 11,0 & 8,64 & 7,39 \\
\hline 6,60 & 7,71 & 9,44 & 8,49 \\
\hline 7,23 & 8,80 & 7,94 & 8,34 \\
\hline 8,96 & 8,81 & 8,17 & 9,59 \\
\hline 6,60 & 8,01 & 6,36 & 6,45 \\
\hline
\end{tabular}

Os resultados obtidos para avaliação do coeficiente de uniformidade de Christiansen (CUC)se encontram na Tabela 3. Onde se pode observar que o pior resultado do coeficiente de uniformidade de Christiansenfoi encontrado no lote 1P51, exatamente no lote em que os aspersores estão dispostos com espaçamentos maiores que é de 12 x12 m. No entanto o valor encontrado que foi de 77,06 \% está classificado como razoável de acordo com Mantovani(2001).

O lote 3P05 foi o que apresentou o melhor resultado de CUC que foi de 86,65 \% seguido do lote 1 P32 que foi de 82,39\%, ambos com aspersores espaçados de 6 × 6 m e classificados como bom, segundo Mantovani (2001).

Pereira et al.(2011) avaliou o CUC no perímetro irrigado de Formoso, município de Bom Jesus da LapaBA para três diferentes espaçamentos e em geral os resultados foram piores quando o espaçamento entre os aspersores aumentou. Para o espaçamento 12 × $12 \mathrm{~m}$ os resultados variaram de 71,30\% a $87,30 \%$ sendo que o CUC em $57 \%$ dos lotes foi classificado como razoável em quanto que em $43 \%$ dos lotes foi classificado com bom.

Tabela 3. Coeficiente de Uniformidade de Christiansen e Coeficiente de Uniformidade de Distribuição nos lotes do perímetro irrigado Jacarecica I.

\begin{tabular}{|c|c|c|c|c|}
\hline LOTES & CUC (\%) & Classificação & CUD (\%) & Classificação \\
\hline 1P51 & 77,06 & Razoável & 67,68 & Razoável \\
\hline 1P32 & 82,39 & Bom & 77,33 & Bom \\
\hline 3Р05 & 86,65 & Bom & 81,08 & Bom \\
\hline
\end{tabular}

Fonte: Mantovani 2001.

Na Tabela 3 também contém os resultados obtidos do coeficiente de uniformidadede distribuição (CUD) dos três lotes avaliados. Em que os resultados se assemelham ao do CUC e a classificação segundo Mantovani (2001) permaneceu inalterada, com o lote 1P51 classificado como razoável e os lotes 2P05 e 1P32 como bom.

Rocha et al. (1999) avaliaram CUC e CUD em sistema de irrigação por aspersão com os aspersores espaçados 12 x 12 m,encontrando valores de CUC entre 69,3 e 78,0\% e de CUD entre 55,4 e 68,4\%, valores estes que consideraram aquém dos valores mínimos recomendados, destacando que baixos valores de uniformidade de aplicação de água na superfície do solo, principalmente em solos leves, podem resultar em elevadas perdas de água porpercolação.

Os valores de CUC e de CUD encontrados estão em níveis dentro dos padrões de classificação, considerando que os irrigantes não estão trabalhando com culturas de alto valor econômico. Mas não se 
pode deixar de registrar as diversas alterações realizadas pelos irrigantes em relação ao projeto original e dos diversos vazamentos que podem ser facilmente visualizados tanto nas linhas principal e de distribuição, como na linha lateral. Sendo que estes problemas de vazamentos podem ser resolvidos com a troca da tubulação, apresentando ainda um melhor resultado se for realizado uma alteração para um sistema fixo, pois as movimentações das linhas laterais nas posições para funcionamento da irrigação sobre a área do projeto ocasionam perdas de água e requerem uma maior atenção na manutenção para não gerarem vazamentos, além da economia de mão-de-obra que se encontra cada vez mais escassa.

Entretanto esse procedimento tem um custo que necessita levar em consideração que o perímetro é composto por pequenos lotes, pertencentes a agricultores familiares, com pouco recurso financeiro para investimento na atividade e que o perímetro irrigado é público. Entretanto este desperdício de água não pode ser aceito nos dias atuais devendo o poder público tomar providências para resolver tal situação.

\section{CONCLUSÕES}

A pressão de serviço e a vazão dos aspersores avaliados estão bem abaixo dos valores estabelecidos no projeto.

Os valores encontrados de CUC e CUD estão dentro dos níveis de classificação entre razoável e bom.

Foram constatados inúmeros vazamentos nas tubulações e nas conexões que resultam em desperdício de água e comprometem o desempenho do sistema de irrigação.

0 perímetro irrigado está funcionando totalmente em desacordo com o que foi projetado, necessitando de intervenção para que seja realizado um redimensionamento e implantação de um novo sistema de irrigação substituindo os materiais existentes.

\section{REFERÊNCIAS}

[1] BERNARDO, S.; SOARES, A.A.; MANTOVANI, E.C. Manual de irrigação. $7^{\circ}$ ed. Viçosa, MG, UFV, 2005. 611p.

[2] BURT, C.M.; CLEMMENS, A.J.; STRELKOFF, T.S.; SOLOMON, K.H.; BLIESNER, R.D.; HARDY,

[3] L.A.; HOWELL, T.A.; EISENHAUER, D.E. Irrigacion performance measures: efficiency and uniformity. Journal of Irrigation and Drainage Engineering, New York, v. 123, n. 6, p. 432-

[4] 442. Nov.-Dec, 1997.

[5] CARVALHO, D.F.; OLIVEIRA, L.F.C. Planejamento e manejo da água na agricultura irrigada. Viçosa, MG: Ed. UFV, 2012. 240p.

[6] LOPES, E.S.A.; MOTA, D.M. Tecnologia e renda na agricultura familiar irrigada de Sergipe. São Cristovão, SE: Universidade Federal de Sergipe; Aracaju, SE: Embrapa CPATC, 1997.

[7] MANTOVANI, E.C. Avalia: Programa de Avaliação da irrigação por aspersão e localizada. Viçosa, MG: UFV, 2001.

[8] MEDEIROS, S.S.; SOARES, A.A.; RAMOS, M. M.; MONTOVANI, E.C.; SOUZA, J.A.A. Avaliação do manejo da irrigação no perímetro irrigado de Pirapora, MG. Revista Brasileira de Engenharia Agrícola e Ambiental, v.27, n1, p.80-84, 2003.

[9] OLIVEIRA, F.G.; FIGUEIREDO, F.P.; OLIVEIRA, P.M.; COSTA, E.L. Avaliação de sistemas de irriação. Informe Agropecuário, v.31, n.259, p.43-49, 2010.

[10] OLIVEIRA, S.L.Irrigação. In: ALVES, E.J. A cultura da banana: aspectos técnicos, socioeconômicos e agroindustriais. 2.ed. rev. Brasília: Embrapa-SPI/ Cruz das Almas: Embrapa-CNPMF, 1999, p.317-332.

[11] PEREIRA, F.A.C.; SANTOS, R.P.; INIGUEZ, L.M.; PAZ, V.P.S., GOMES JUNIOR, J.F. Avaliação

[12] da qualidade da irrigação e caracterização físico-hídrica em lotes do perímetro irrigado do formoso, Bom Jesus da Lapa, Bahia, Brasil. In: LUCAS, A.A.T.; AGUIAR NETTO, A.O. Águas do São Francisco. São Cristovão, SE: Editora UFS,2011.

[13] ROCHA, E.M.M.; COSTA, R.N.T.; MAPURUNGA, S.M.S.; CASTRO, P.T. Uniformidade de distribuição de água por aspersão convencional na superfície e no perfil do solo. Revista Brasileira de Engenharia Agrícola e Ambiental. V.3, n.2, p.154-160. Campina Grande, PB, UFPB, 1999.

[14] SOUSA, V.F.; MAROUELLI, W.A.; COELHO, E.F.; PINTO, J.M.; COELHO FILHO, M.A.Irrigação e fertirrigação em fruteiras e hortaliças. Brasília, DF: Embrapa Informação Tecnológica, 2011. 771p. 


\section{ANEXOS}

Figura 4. Medição da pressão de serviço do aspersor avaliado.

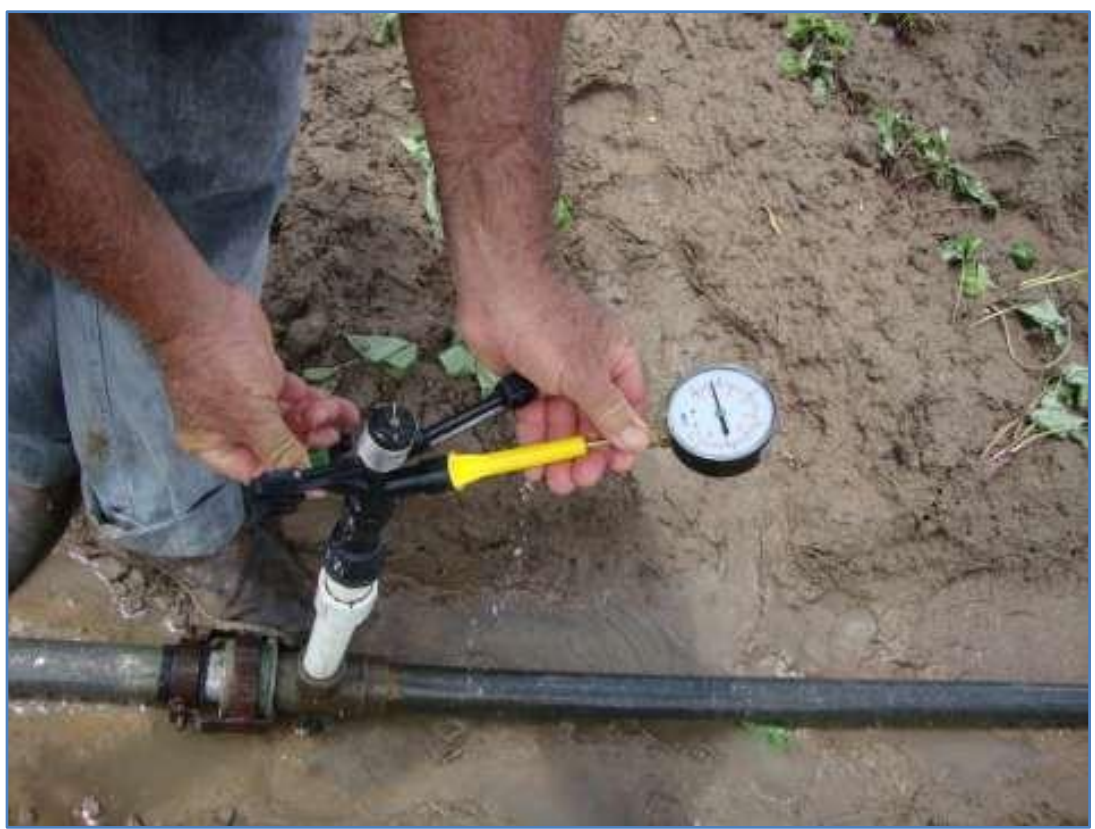

Figura 5. Sistema de irrigação em funcionamento na ocasião do teste, área ocupada com a cultura da batata em fase inicial.

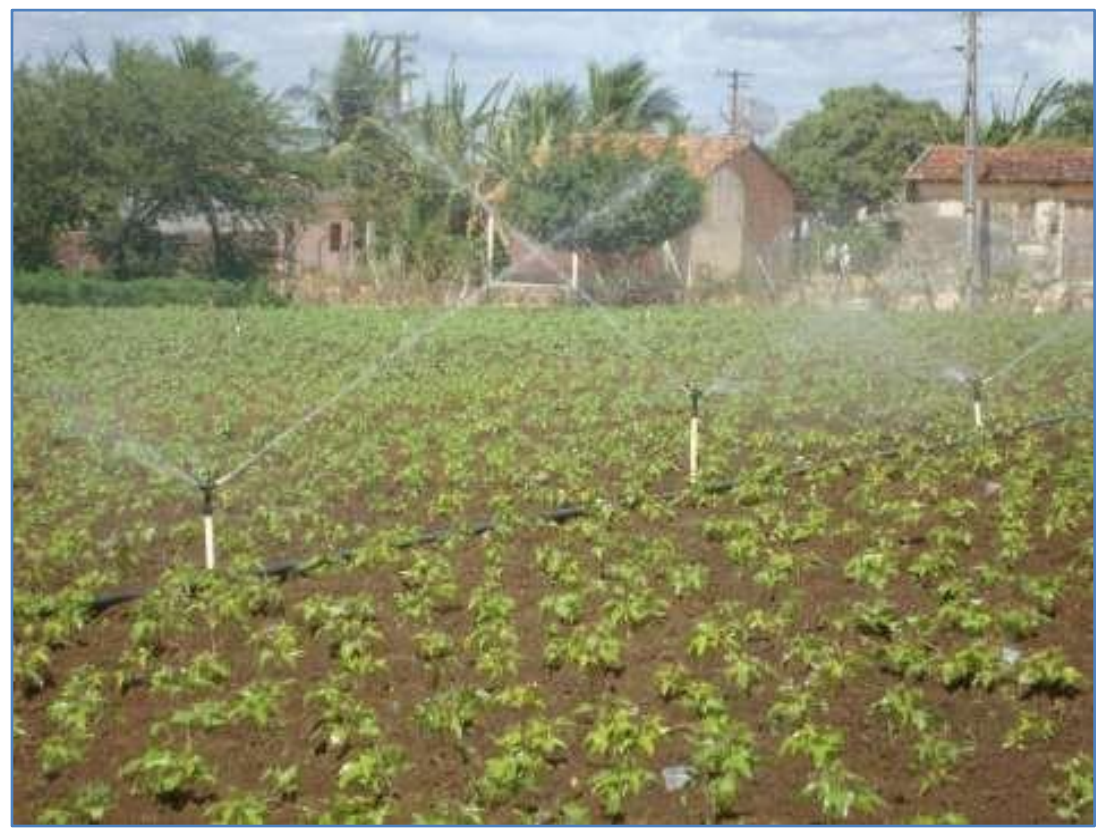


Figura 6. Cultivo da batata-doce irrigada no perímetro.

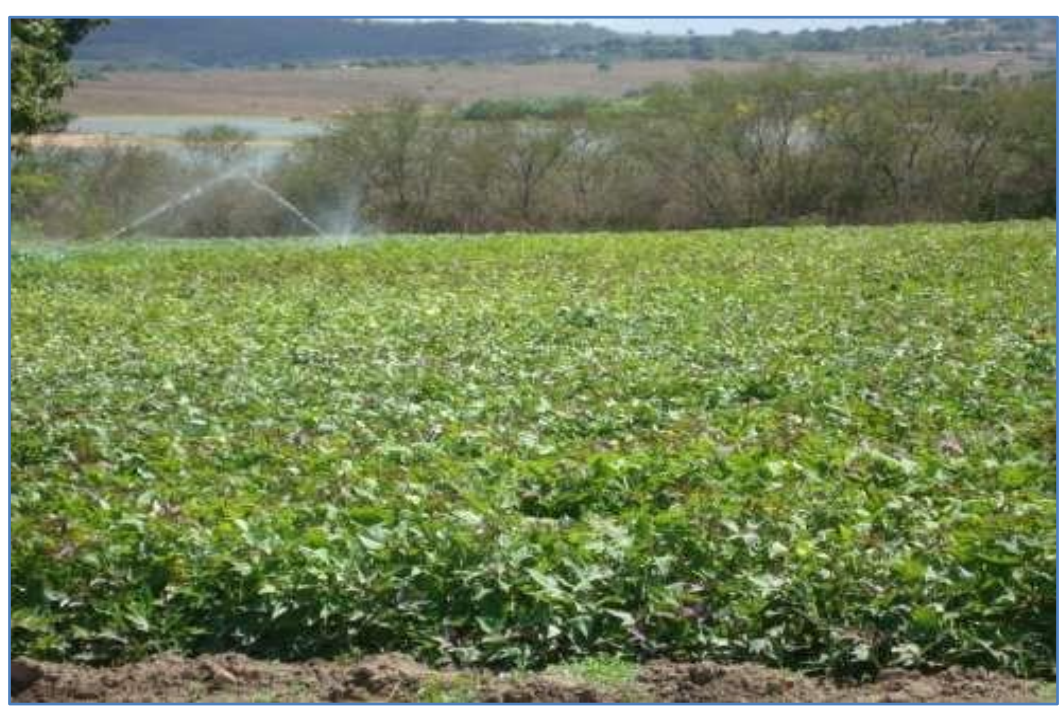

Figura 7. Vazamentos nas conexões de engate rápido com a linhalateral.

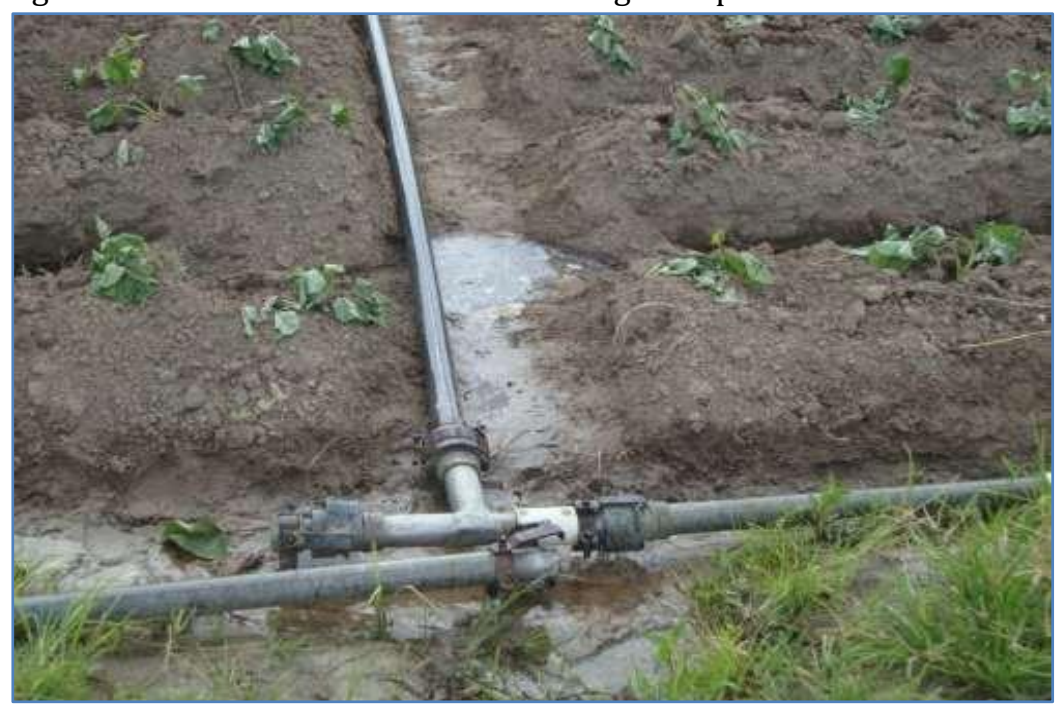


Figura 8. Vazamento próximo ao aspersor comprometendo o seu funcionamento, diminuição da vazão.



Figura 9. Acúmulo de água após irrigação da cultura da batata-doce transplantada.

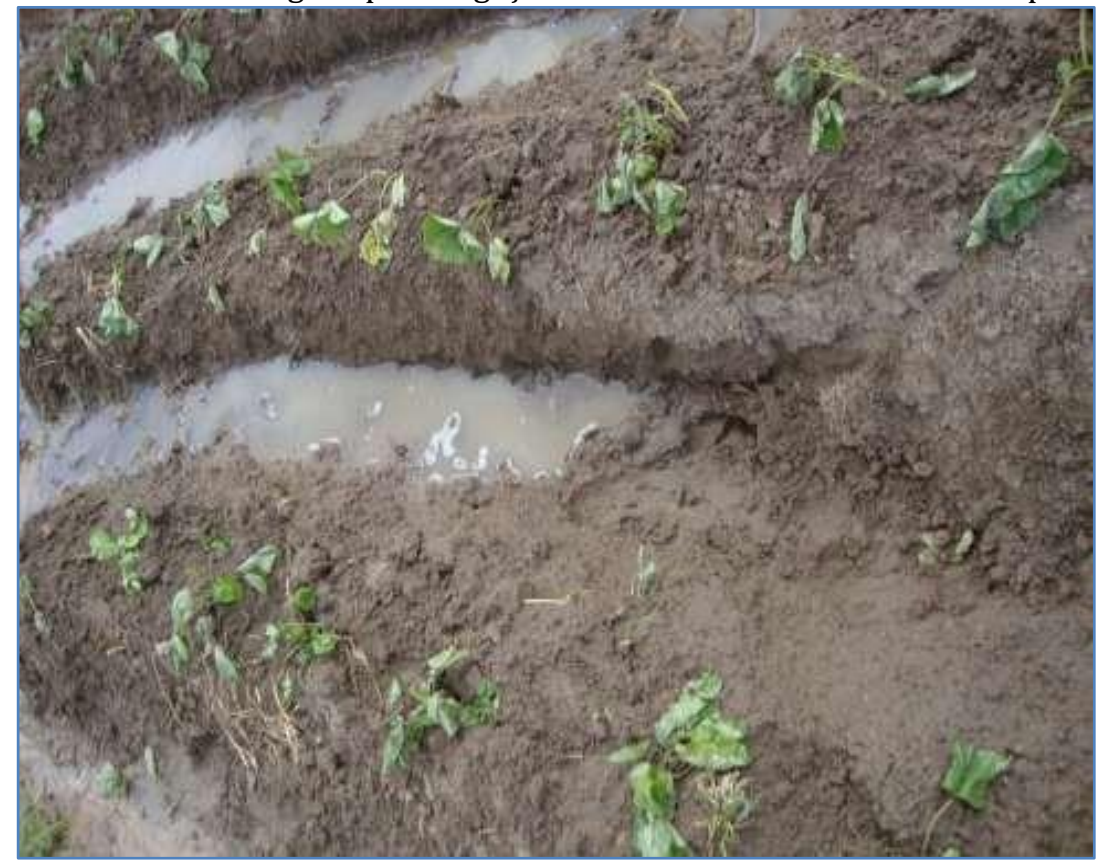


Figura 10. Vazamento na tubulação nas proximidades do hidrante.

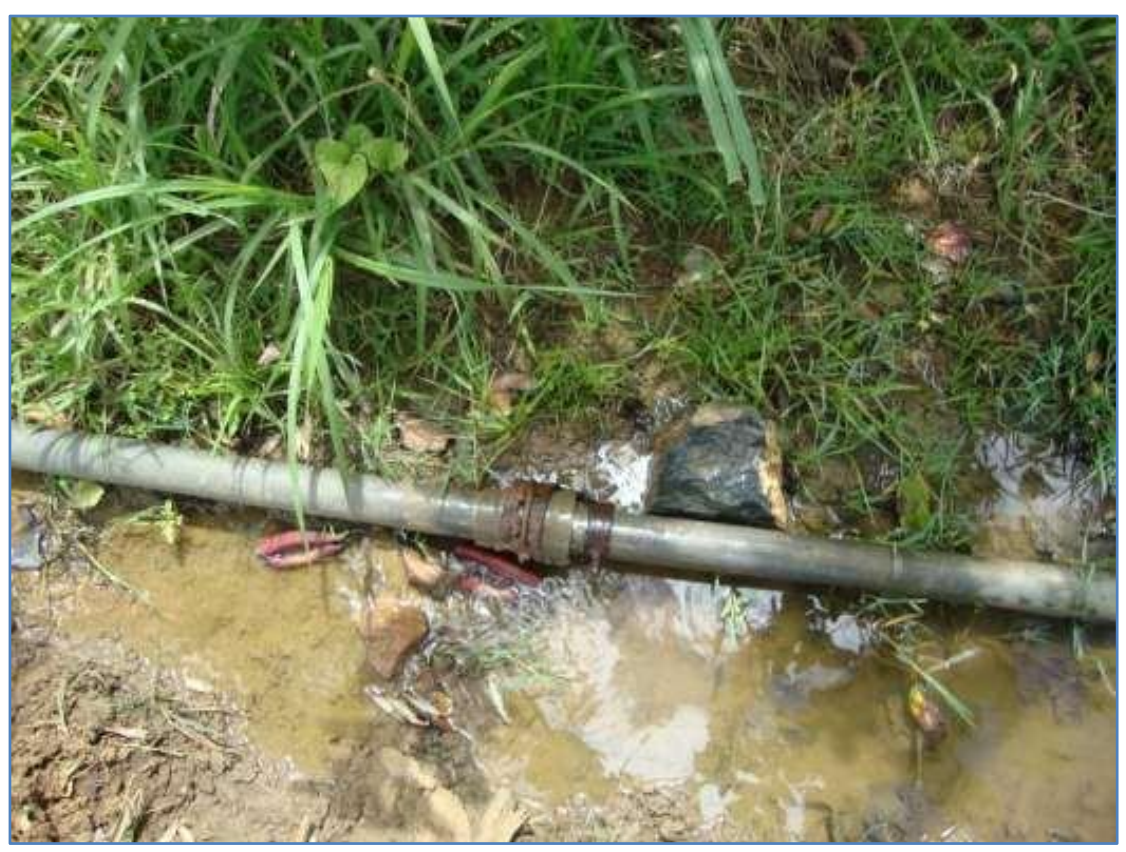

Figura 12. Estação agrometeorológica do perímetro irrigado Jacarecica.

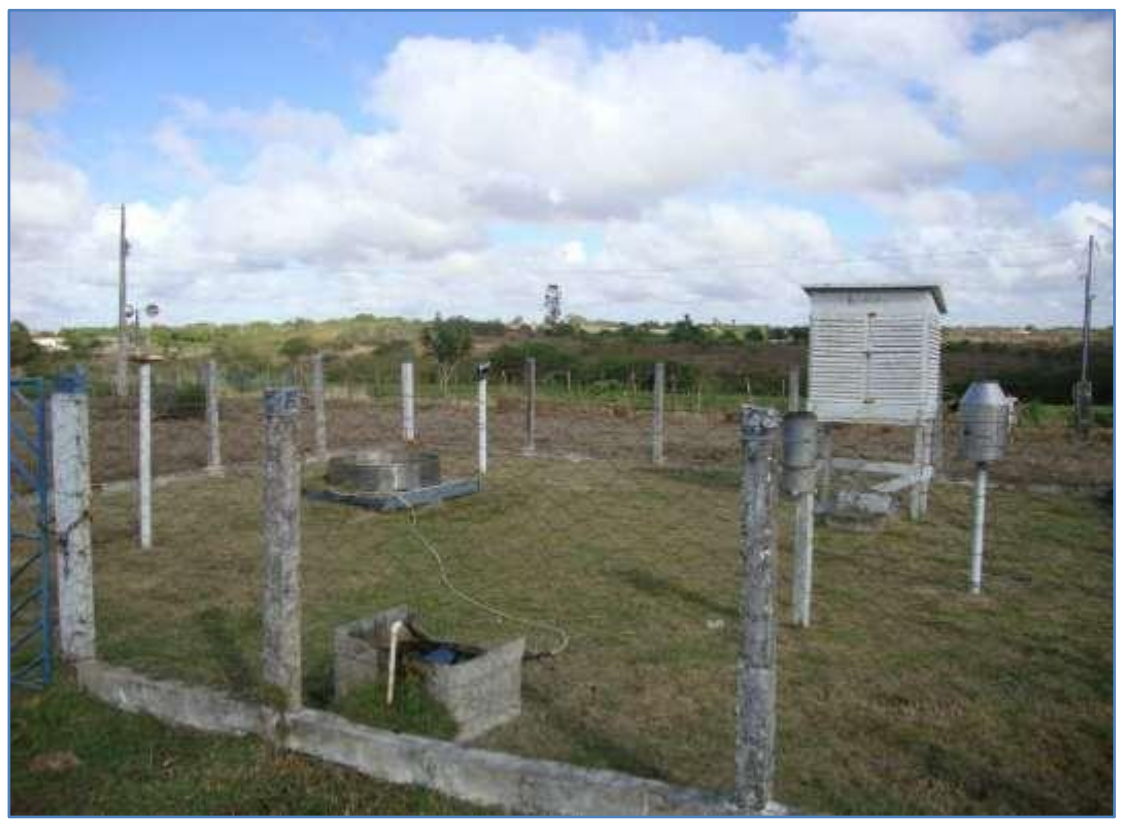




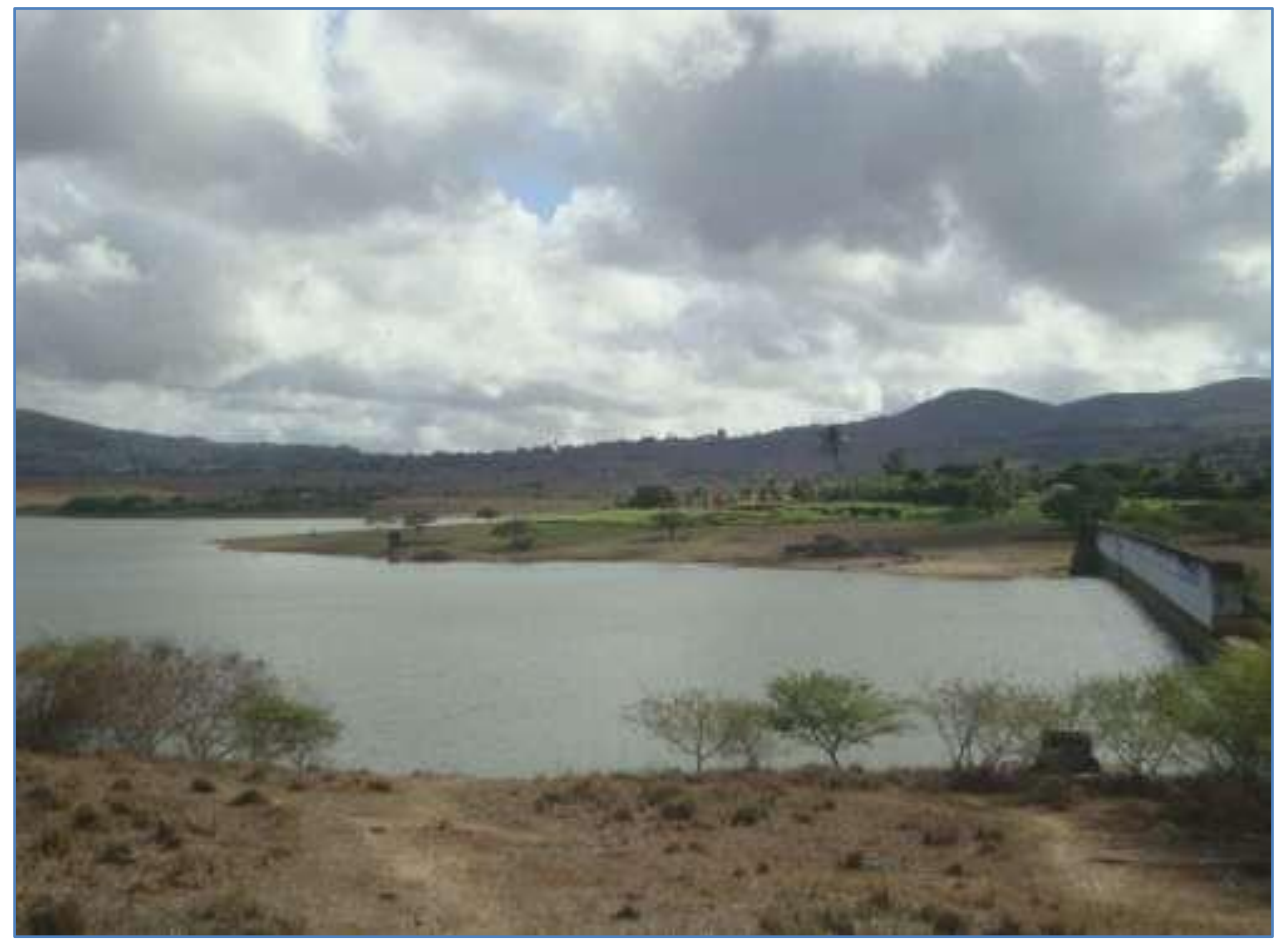




\title{
CAPÍTULO \\ Impactos ambientais na sub-bacia hidrográfica do rio Jacarecica
} 07

\author{
Lanielle Amarante Santana \\ Josefa Eliane Santana de Siqueira Pinto
}

\section{INTRODUCCÃO}

Na história da humanidade a relação homem versus natureza foi marcante. Desde a formação das primeiras civilizações, o homem se preocupa em armazenar água, tanto para uso comunitário como para irrigação de cultivos agrícolas ou para dessedentação animal. E, talvez por isso, o agrupamento social tenha ocorrido próximo aos cursos dos rios, como maneira de garantir a sua subsistência.

Com a evolução agrícola, as civilizações que povoaram a Europa modificaram por completo os territórios ocupados, explorando bosques, florestas e transformando em campos agrícolas. Esse foi o modelo adotado pelo Brasil no século XVIII e baseia-se no desmatamento de extensas áreas florestadas para exploração da madeira, depois abandonada para a pecuária extensiva, sendo substituída para vegetação rasteira manipulada de forma inadequada, levando a maior exposição do solo, susceptível a processos erosivos e perda da capacidade de absorção de água, provocando escoamento superficial, intensificando a erosão e o assoreamento dos rios. Cordani (2000, P.31).

Por sua vez, com o aperfeiçoamento das técnicas de trabalho e aumento da população, novas e maiores exigências foram surgindo, quer para o abastecimento humano, dos animais, da agricultura, quer para uso industrial e produção de energia.

Assim, com a crescente utilização e exploração dos recursos naturais pelo homem, a natureza vem adquirindo sinais de fragilidade, e, dentre as consequências desta exploração, destaca-se a degradação ambiental nas bacias, sub-bacias e microbacias hidrográficas. Entende-se que o impacto ambiental agrava o desequilíbrio regional principalmente no que se refere ao aspecto socioeconômico, comprometendo a produção agrícola, levando a população atingida a migrar para os centros urbanos, dentre outros.

Como tentativa de diminuir os impactos socioambientais, nas últimas décadas, foram iniciadas discussões sobre a temática ambiental, entre as quais vale destacar a Conferência das Nações Unidas para o Meio Ambiente, em Estocolmo 1972, Conferência das Nações Unidas sobre o Meio ambiente e Desenvolvimento (Rio 92), em que os recursos naturais, sobretudo os renováveis vêm sendo pautados. Essas conferências foram importantes, pois apontaram os problemas ambientais e seus efeitos para toda sociedade e natureza, frisando a necessidade de mudanças no modelo de desenvolvimento econômico e no comportamento do homem em relação aos recursos naturais, com a finalidade de buscar soluções para a problemática apresentada, dentre elas, a ocorrência de degradação dos mananciais e afluentes em bacias hidrográficas podendo vir a comprometer a disponibilidade e sustentabilidade hídrica no mundo.

Com isto, busca-se aqui identificar, refletir e disseminar discussões a respeito de impactos ambientais em função da exploração e degradação de recursos naturais, tendo como referência a sub-bacia hidrográfica do rio Jacarecica em Sergipe.

Este tema tem a importância de estimular governantes a elaborarem um Plano de Gestão de Recursos Hídricos, com o objetivo de regularizar e ordenar o uso do território, preservar e recuperar os mananciais, garantindo para as gerações futuras, o desenvolvimento sustentável local. Entende-se que o processo de conscientização deve ser também direcionado para a sociedade.

Para o desenvolvimento da temática, os procedimentos metodológicos são importantes como guia do raciocínio, da pesquisa e do leitor, pois propiciam uma visão holística do que está sendo abordado e de que forma, tendo um conhecimento das etapas da elaboração, do caminho operacional, fundamentadas em estudos anteriores sobre tema semelhante, abordando realidades diversas. 
Entre indicadores e guias utilizados, faz-se necessário: Detectar os agentes causadores da degradação ambiental; identificar as localidades com maior impacto; Avaliar as consequências dos problemas ambientais e seus reflexos.

Segundo Marconi e Lakatos (2001, p. 105) a metodologia responde ao mesmo tempo às questões como? com que?, onde? e quanto?. Desta forma, a escolha dos elementos irá depender de fatores distintos, a exemplo dos objetivos, natureza e questões norteadoras da pesquisa.

A problemática do meio ambiente não é um tema novo para a Geografia, mas tratá-la por meio de um aporte teórico- metodológico que pretenda lidar com a complexidade dos fenômenos entre natureza e sociedade se torna um desafio. (COSTA, 2013, P.39)

Sendo assim, trata-se de uma pesquisa do tipo explicativo-descritiva que pretendeu analisar os principais problemas ambientais, promotores da degradação na sub- bacia do rio Jacarecica, em Sergipe. Tem-se em mente que os atributos naturais estão sendo alvo de interferências antrópicas, quer em seu aspecto positivo, quer em seu aspecto negativo.

As informações obtidas no primeiro momento fundaram-se em pesquisa bibliográfica e documental, com análise dos problemas ambientais nas Bacias Hidrográficas no Brasil, através de livros, artigos científicos, Dissertações de Mestrado e Teses de Doutorado. Tais informações levaram em consideração aspectos geográficos no contexto da bacia, para a caracterização da área estudada. Foram realizadas viagens, visando identificar áreas com maior degradação, detectando as suas causas, podendo assim diagnosticar as consequências ocorridas nos últimos anos.

\section{AMBIENTE NATURAL, IMPACTOS, RISCOS E VULNERABILIDADE}

A Constituição Federal de 1988 foi a primeira constituição brasileira a tratar do termo meio ambiente, no caput do artigo 225, onde retrata ser dever do Poder Público e da coletividade preservar e conservar o meio ambiente, pois ele é de uso e bem comum de todos os povos, essencial para qualidade de vida. "A Constituição define meio ambiente como "um bem de uso comum do povo" e determina ao Poder Público, bem como a toda a população, o dever de defendê-lo e preservá-lo para os presentes e futuras gerações". A partir daí resultou a implementação de políticas públicas com caráter ambiental no Brasil. No período colonial a legislação restringia-se, á proteção florestal, com poucos resultados.

Segundo Ruscheinsky (2002), a exploração predatória do meio ambiente não pode ser impedida com a simples imposição da ideia de intocalidade, contenção ou retenção do uso do ambiente; exige sim, a inclusão social e econômica de forma a buscar o bem-estar social para todos. Meio Ambiente e sociedade encontram-se intimamente associados; por isso é necessário compreender a problemática ambiental na sua complexidade.

Nascimento (2006), citando Trigueiro, considera que o meio ambiente é "um conjunto de fatores naturais, sociais e culturais que envolvem um indivíduo e com os quais ele interage influenciando e sendo influenciado por eles". Dessa forma, cabe à sociedade usufruir o meio ambiente de modo que não agrida os recursos naturais, sabendo utilizar a natureza de acordo com as suas necessidades, servindo de práticas agroecológicas e manejo adequado da água e do solo.

A água é a fonte de vida mais importante do mundo, pois sem ela os seres vivos não sobreviveriam. Mesmo assim, as ações humanas vêm comprometendo a qualidade e quantidade de água potável existente no planeta. Dessa forma o fornecimento de água potável poderá ser um grande desafio para toda a humanidade, uma vez que a contaminação vem crescendo, em todo mundo, principalmente nas zonas costeiras, e nas grandes cidades. Segundo MORAES (2005), a devastação vegetal associada ao crescimento urbano e a expansão agrícola, são os fatores que mais contribuem para o comprometimento dos mananciais.

Assim, com a falta de planejamento nos centros urbanos, a deficiência da coleta do lixo e os impactos das construções e indústrias, estão poluindo cada vez mais os rios, e, em muitos casos a degradação se torna irreversível, pois os elevados índices de poluição das águas dificultam o tratamento e reduz a oferta de água potável.

Há de se pronunciar sobre os altos custos de tratamento e que ainda hoje, os dejetos da maioria das grandes cidades, são lançados nos rios e que a poluição e assoreamento têm crescido, devido ao desmatamento, queimadas, ocupação desordenada nas áreas de mananciais e florestas. Tais fatores 
associados ou isolados levam a população a contrair doenças como amebíase, cólera, dengue, esquistossomose, febre amarela, hepatite e leptospirose, malária entre outras. Entretanto se tivermos água de boa qualidade a aquisição de diversas doenças poderá reduzir, diminuir a taxa de mortalidade aumentando a expectativa de vida da população.

Relatórios da Organização Mundial de Saúde mostram que cerca de 4,6 milhões de crianças de até cinco anos morrem por ano de diarreia, doenças relacionadas à ingestão de água não potável, agravada pela fome e má distribuição de renda, que atinge cerca de meio milhão de pessoas em países pobres.

Levantamento do Ministério da Saúde em 2005 conclui que a população está adoecendo por causa da poluição da água e do solo. As atividades humanas quando não realizadas de forma ordenada podem causar alterações no meio ambiente ocasionando desequilíbrios. Como integrante direto deste processo o homem pode ser afetado por ela, trazendo prejuízo à sua saúde e provocando danos aos seus bens (FALKENMARK, 1992, p. 67). O Planeta nas ultimas décadas, vem sofrendo mudanças, vista por todo o mundo, como a redução das florestas, as chuvas ácidas, poluição do ar, degradação das águas e exaustão dos mananciais, agravamento da seca, como contingente de ações em diversas regiões no mundo (NASCIMENTO, 2006).

o CONAMA-Conselho Nacional de Meio Ambiente, em sua resolução 001(23/01/86) define impacto ambiental, como:

Qualquer alteração física, química e biológica do meio ambiente causada por qualquer forma de ação humana [...] e que afetam a saúde, segurança e bem estar da população; as atividades sociais e econômicas; a biota; as condições estéticas e sanitárias do meio ambiente e a qualidade dos recursos ambientais.

Esse conceito leva em consideração a ação humana sobre a natureza, sociedade e economia. E com a ausência de planejamento dos recursos hídricos ocorre a degradação ambiental e a partir do estudo da bacia hidrográfica faz entender os problemas ambientais. Guerra (1996) diz que a bacia deve compreender espaço de preservação ambiental, desenvolvimento econômico, integrando as condições do comportamento natural e humano, sendo necessário um planejamento sustentável de sua utilização.

Cazulo citando Christofoletti (1980) assegura que as bacias hidrográficas são compostas por um conjunto de canais de escoamento de água. A quantidade de água que a bacia hidrográfica vai receber depende do tamanho da área ocupada pela bacia hidrográfica e por processos naturais que envolvem precipitação, evaporação, infiltração, escoamento, etc. Também compreendida como rede hidrográfica, a mesma é uma unidade natural que recebe a influência da região que drena, é um receptor de todas as interferências naturais e antrópicas que ocorrem na sua área tais como: topografia, vegetação, clima, uso e ocupação etc. Assim um corpo de água é o reflexo da contribuição das áreas no entorno, que é a sua bacia hidrográfica.

Esta, além de ser uma unidade física, também é um espaço de ação política, administrativa, de tomada de decisões, principalmente quando os problemas de poderes públicos começam a intervir sobre forma de comitês de bacia, de forma partilhada e participativa com representantes dos usuários, sociedade civil e governo.

O modelo de gestão das bacias hidrográficas, adotada na legislação brasileira e baseado na descentralização das tomadas de decisões, nesse sentido os comitês de bacias e as agencias de água representam (re) arranjos institucionais com o objetivo de conciliar interesses diversos e muitas das vezes antagônicos, assim como controlar conflitos e repartir responsabilidades. Cunha e Coelho (2003, P.71)

A partir da lei 9.433/97 as bacias hidrográficas foram reconhecidas como unidades, de planejamento, valor econômico, gestão no plano público, tendo como base legal a implementação dos planos estaduais de recursos hídricos. Foi então definida a Política Nacional de Recursos Hídricos e criado o Sistema Nacional de Gerenciamento de Recursos Hídricos, assegurando a disponibilidade de água para as gerações futuras com qualidade e a preservação e a defesa dos recursos naturais. Essa lei fortalece a mudança de atitude dos administradores públicos e dos usuários perante o processo de gerenciamento dos mananciais. Com a necessidade de um modelo de gestão descentralizado e participativo. Essa discussão também foi feita de forma mais ampla pela Agenda 21, no eixo de gestão de recursos naturais, destacando os aspectos sociais, políticos, ressaltando a necessidade de mapear, quantificar e proteger os recursos hídricos doces para uso e melhoria de sua qualidade hídrica. 
A utilização dos recursos hídricos vem gerando discussões nos últimos anos, de como melhorar sua gestão e evitar a escassez. Uma vez que vem sofrendo um processo de degradação de suas características, físicas, biológicas e químicas, resultando num quadro em que a água doce do mundo, apresenta algum tipo de contaminação, acarretando efeitos nocivos á saúde humana. Assim os impactos ambientais como desmatamento, assoreamento, erosão, compactação, dentre outras degradações, tem contribuído para a desertificação, o desaparecimento de rios e lagos, afetando profundamente o ciclo da água e do clima.

Segundo Borsato (2004), com o crescente uso da água para diversos fins, o estado de degradação em que se encontram os mananciais, é necessário administrar sua disponibilidade e uso, além do conhecimento atualizado do quadro degradante quando houver e criar processos de gerenciamento para sua recuperação e/ou conservação, assegurando desta maneira a qualidade e quantidade dos recursos que esta pode oferecer.

É interessante ressaltar que natureza e sociedade se completam e interagem, considerando que cada período e cada espaço têm suas singularidades e que estudá-los constitui-se tentativas de compreensão de processos em permanente transformação.

Neste sentido, a Natureza não pode ser compreendida como algo dado, estático e objetivo. Ela é subjetiva e não podemos considerá-la como verdade absoluta, externa ao homem; ela é criada por ele dentro de um contexto histórico, filosófico e geográfico específico. Em tempo algum ela é o que é; a Natureza é o que os homens denominam que ela seja, uma vez que: conceito ou definição nada mais é do que uma construção humana. E a partir desta construção humana estabelecemos formas de concebê-la e de nos relacionarmos com ela. (MENDONÇA, 2012, P. 380)

Portanto é imprescindível que desde o planejamento a gestão de bacias hidrográficas ocorra a participação dos usuários para que possam ter conhecimento do ambiente em que vivem das suas fragilidades e potencialidades e respeitar as normas de uso e conservação do solo e da água, utilizando de forma sustentada, evitando os impactos ambientais em torno da bacia.

Para Christofoletti (1994), os impactos ambientais significam ações realizadas pelas mudanças do meio ambiente nas circunstâncias que envolvem a vida dos seres humanos, que aqui se incluem as transformações provocadas pelas ações humanas nos aspectos do meio ambiente físico e que se refletem, por interação, nas condições ambientais que envolvem a vida humana. Assim o impacto ambiental pode ser tanto positivo ou negativo ocasionado pelo homem ou pela própria ação da natureza. Sendo mais importante que identificar os impactos, é prevê-los. Portanto é fundamental a realização de estudos ambientai antes de instalar qualquer atividade econômica na bacia.

Impactos de grande proporção e em uso habitual dizem respeito ao desmatamento, as técnicas agrícolas inadequadas, o mau uso do agrotóxico que leva contaminação dos corpos hídricos, modificando as condições naturais dos mananciais, alterando a qualidade da água. Em muitas vezes é conduzida por produtores rurais que não possuem consciência de preservar a natureza e/ou não tem conhecimento de técnicas

Além dos recursos tecnológicos não estão disponíveis em termos favoráveis aos pequenos agricultores familiares, não se adequam as suas condições econômicas e não foram capazes de resolver os problemas ambientais nem a miséria no campo nos países em desenvolvimento.

Após o surgimento da questão ambiental, eclodiu importantes mudanças na visão do mundo, e a humanidade percebeu que os recursos naturais são finitos e que seu uso incorreto representar o fim de sua própria existência, e com o surgimento da consciência ambiental, a ciência e a tecnologia passaram a ser questionadas. BERNARDES e FERREIRA (2003:27).

Alguns movimentos ambientalistas, associações de moradores, comunidades, naturalistas, estudantes vem se organizando no intuito de defender o meio ambiente, impedindo a degradação dos espaços em que vivem. Pressionando mudanças nas políticas públicas e na própria sociedade, na busca por um desenvolvimento econômico que seja sustentável. Segundo Ferreira (2003) a salvação da humanidade e do planeta depende, antes, da mudança entre os homens de forma consciente para ser eficaz, resultante de uma inteligência critica, descobrindo as reais formas de organização política da vida, com uma nova 
sociedade no processo de produção, na organização do trabalho, que se estabeleça em novas bases de cooperação.

Assim o levantamento dos impactos ambientais em uma bacia hidrográfica é importante para traçar estratégias de planejamento e elaboração de projetos na busca de preservar, conservar e minimizar os riscos ambientais.

Por Risco Ambiental, a maioria dos autores se refere a uma situação constantemente negativa, associada a uma situação de catástrofe, perigo, ameaça ou probabilidade; a vulnerabilidade pode ser compreendida como risco de degradação do ambiente natural (erosão do solo, assoreamento, perda da biodiversidade etc).

E, por conseguinte, analisar a vulnerabilidade de um espaço permite identificar os do meio ambiente. É a partir desses três elementos risco, impacto, vulnerabilidade, uso e ocupação do território, que se entende os impactos de cada sistema ambiental. Para Santos citando Degg (1992, P.43).

A vulnerabilidade ambiental e a incidência de riscos às vidas humanas encontram-se intimamente relacionados às condições socioeconômicas da população residente em determinado ambiente.

o desequilíbrio ambiental tem sido atribuído ao crescimento desordenado urbano, ao mau uso das terras agrícolas, ao desmatamento da vegetação, vindo a contribuir para o empobrecimento do solo, com impactos para o meio rural, com reflexos no ambiente urbano.

Conservar o meio ambiente passou a ser valorizar o homem assim, busca-se com a proteção ambiental, o desenvolvimento de condições que possam melhorar o conforto, a saúde, alimentação, entre outros, que compõem a elevação da qualidade de vida. (MULLER, 1995, P. 18)

Logo os órgãos ambientais devem avaliar constantemente as atividades industriais, as pedreiras, os matadouros, e demais serviços nas bacias hidrográficas, para fazer avaliações periódicas dos impactos ambientais e se estão cumprindo a legislação ambiental. Sendo fundamental o estímulo da educação ambiental, devendo ser implementada nas escolas, no sentido de conscientizar os alunos, os pais, políticos e comunidade em geral, como uma ferramenta de sensibilização aos problemas ambientais, buscando-se mudança de atitude para uma sociedade sustentável.

Nessa relação dialética entre individuo, sociedade e natureza é que se constrói o processo de uma educação política que forma indivíduos (educandos e educadores) como atores (sujeitos) sociais, aptos a atuarem coletivamente no processo de transformações sociais em busca de uma nova sociedade ambientalmente sustentável. (Cunha, 2003).

Defendida por Paulo Freire, em uma Pedagogia da Esperança, capaz de construir e inovar por aqueles que têm firmeza para a construção de um mundo melhor.

Alguns pesquisadores como Seva (2003) consideram que estamos vivenciando uma crise ambiental devido a uma combinação de fenômenos da natureza (atmosférico, oceânicos e radiação solar) com processos de origem provocados pela ação humana, acompanhado de um padrão tecnológico e energético que vem gerando alterações e riscos a todo planeta, comprometendo a dinâmica da terra e da vida.

Cunha e Coelho (2003, P.64) citando Terborh (1999) alertam que os maiores desafios para a preservação da natureza são problemas de caráter social: superpopulação, desigualdade de poder e riqueza, exaustão dos recursos naturais, corrupção, falta de leis, pobreza e intranquilidade social. E as pressões exercidas pela busca do desenvolvimento econômico e pelo crescimento populacional, seriam as principais causas de destruição da natureza nos trópicos.

Muito embora a relação entre demanda e disponibilidade hídrica seja muito inferior a $100 \%$ para valores médios, isso não significa que não existam déficits. A relação estabelecida na tabela não identifica o conjunto de conflitos de diversas naturezas envolvendo recursos hídricos, bem como aspectos da qualidade dos mananciais, alguns fortemente afetados por poluição, especialmente nas regiões metropolitanas e zonas de sazonalidade climática acentuada. (TOMASONI, PINTO \& SILVA, 2009, P.124). 
Os autores referem-se à construção e análise de uma tabela sobre disponibilidade hídrica para algumas bacias brasileiras, referendando questões relativas aos impactos ambientais sobre recursos hídricos, definidos como elemento central na temática ambiental. Consideram um cenário complexo para a agricultura e um desafio urbano, em áreas justapostas às bacias e sub-bacias hidrográficas.

\section{IMPACTOS AMBIENTAIS NO CONTEXTO DO JACARECICA}

A título de resultado operacional da pesquisa, algumas expropriações foram comprovadas no trabalho de campo, comprometendo o ambiente natural da sub-bacia do rio Jacarecica, na tentativa de percorrer caminhos entre a teoria e a prática.

Um dos fatores de possível contaminação das águas da bacia do Jacarecica, observados em campo é a instalação de Cemitérios em seu entorno, sem cumprir os critérios da legislação. Segundo o CONAMA, sua instalação deve ocorrer a uma distância segura para garantir a qualidade de corpos de água, superficiais e subterrâneos, com estudos e critérios para sua instalação. Tal medida visa assegurar o respeito às Áreas de Preservação Permanente - APP, como também garantir a ausência de risco por contaminação de micro-organismos que proliferam no processo de decomposição dos corpos. Podem contaminar as águas subterrâneas cujas águas alimentam as águas superficiais da bacia do Jacarecica.

0 primeiro trecho diagnosticado fica próximo a nascente no município de Ribeirópolis, no povoado Oiteiro do capim, com aparência degradada pela retirada de argila para ser utilizada na cerâmica, pela lavagem de roupas, conforme afirmação dos moradores. Ao seu redor há criação de bovinos e o cultivo de milho. A vegetação foi retirada para ser útil nas atividades agrícolas e na pecuária extensiva. (Fig.1)

Figura 1 - Extração de areia próximo a nascente

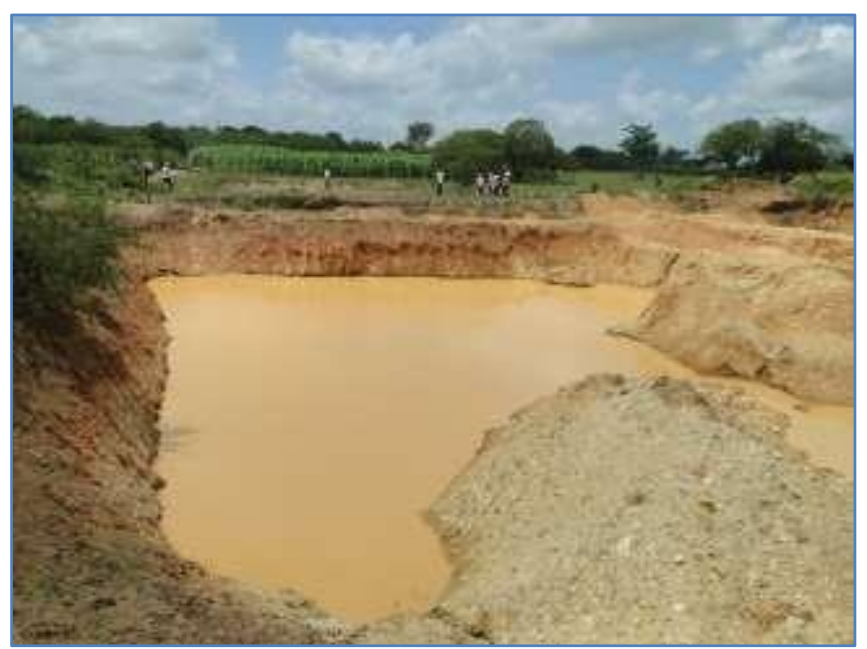

Luiz Carlos Sousa Silva (2012)

Observações locais indicam que a mata ciliar foi substituída por pastagens e agricultura, agravando os impactos ambientais, oriundos de modelos não conservacionistas, pelos quais foram explorados os solos, com a destruição da vegetação, como vem acontecendo com as margens do rio estudado. 0 solo desagrega com mais facilidade, pois perde sua vegetação natural, lançando os sedimentos das margens nas calhas dos rios. (Fig. 2). 
Figura 2 - Município de Itabaiana

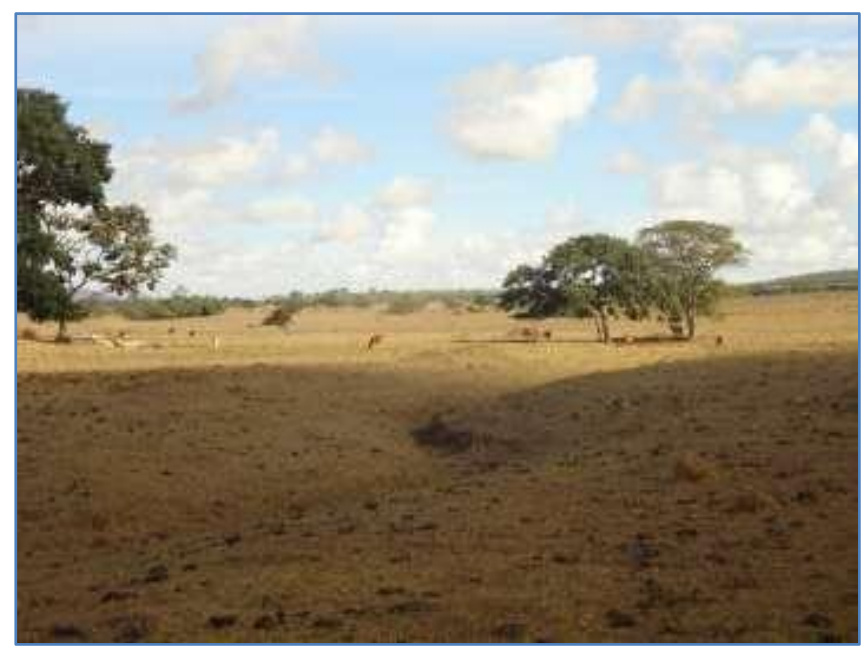

Acervo das Autoras (2013)

Atividades como o corte da mata ciliar, e da vegetação em torno do rio, contribuem para redução da qualidade e quantidade de água do rio e aumenta o processo erosivo culminando com o assoreamento do rio Jacarecica, como observado de fato em alguns trechos. (Fig.3)

Figura 3 - Município de Itabaiana

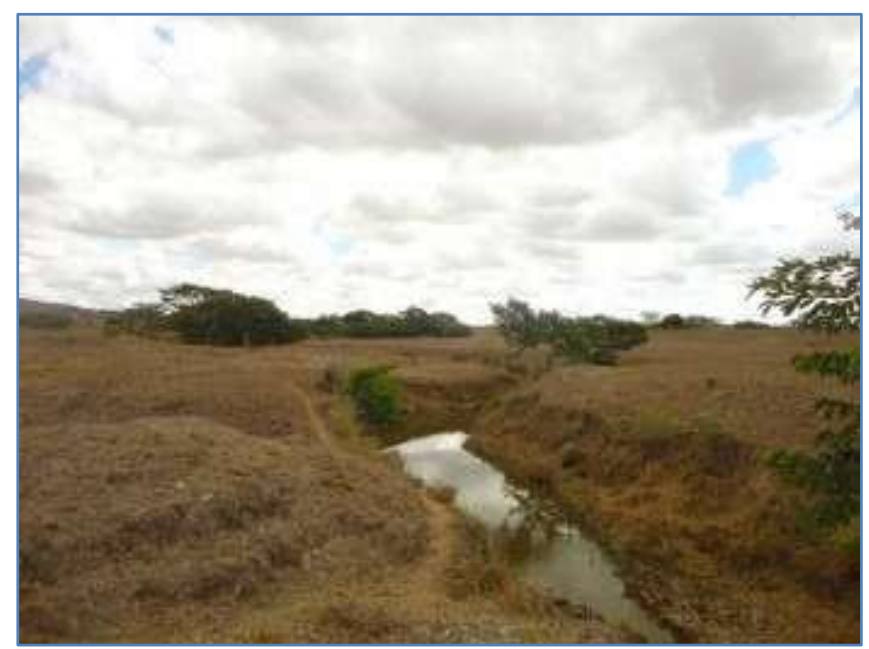

Acervo das Autoras (2013)

Durante as visitas ao local, no período de janeiro á abril, a maioria dos corpos de água encontrava-se secos, e nos trechos em que havia água, pouca presença de mata ciliar, no seu entorno, bastante degradada em virtude da retirada da vegetação principalmente para exploração da pecuária. 0 leito tinha a aparência ressecada dos solos sertanejos, tão reincidente. (Fig.4) 
Figura 4 - Médio Curso do Rio Jacarecica

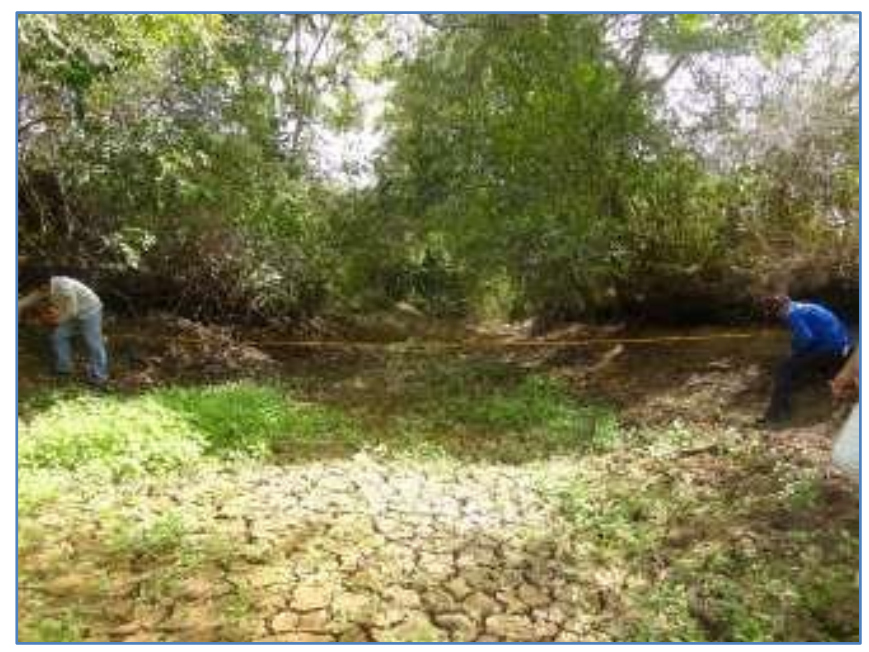

Acervo das Autoras (2013)

A Jusante da Barragem do Jacarecica II, próximo à adutora de captação de água da DESO, no município de Malhador, a agricultura estava presente, com aplicação de agrotóxico no cultivo, contaminando o solo e o corpo hídrico, além do que o agricultor sem equipamento de proteção individual - EPI. (Fig.5). A presença de substâncias tóxicas na água é uma das causas mais graves de contaminação da água destinada ao abastecimento público, principalmente quando se refere aos agrotóxicos, necessitando de programas de monitoramento ambiental para regular seu uso.

Figura 5 - Próximo á adutora de captação de água da Deso.

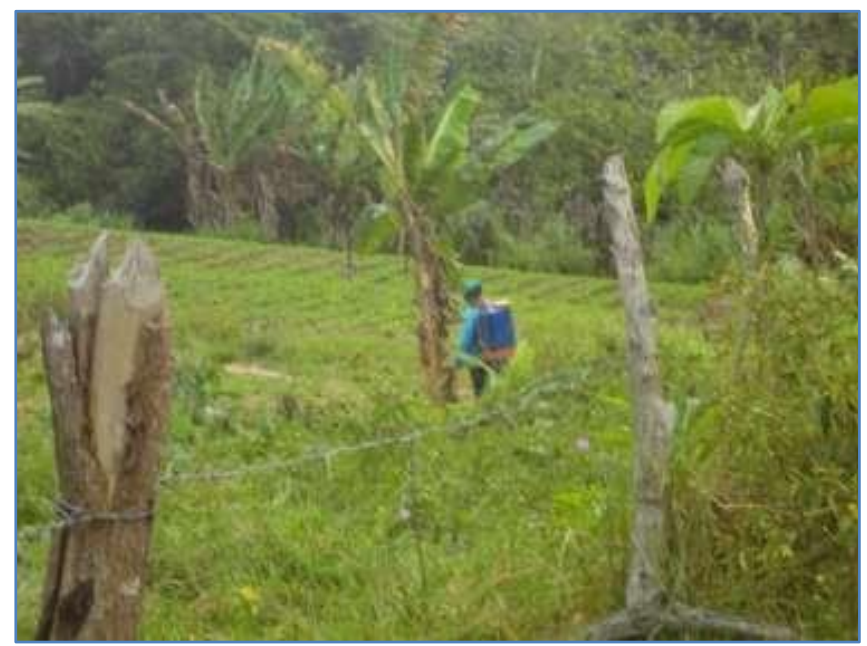

Acervo das Autoras (2012)

A Estação de captação de água do Riacho do Cajueiro do Veado, na sub-bacia em questão, encontrava-se com o curso de água de nível baixo no período de novembro. No percurso, há formação de assoreamento e de bancos de areia. (Fig.6) 
Figura 6 - Estação de captação de água-Malhador

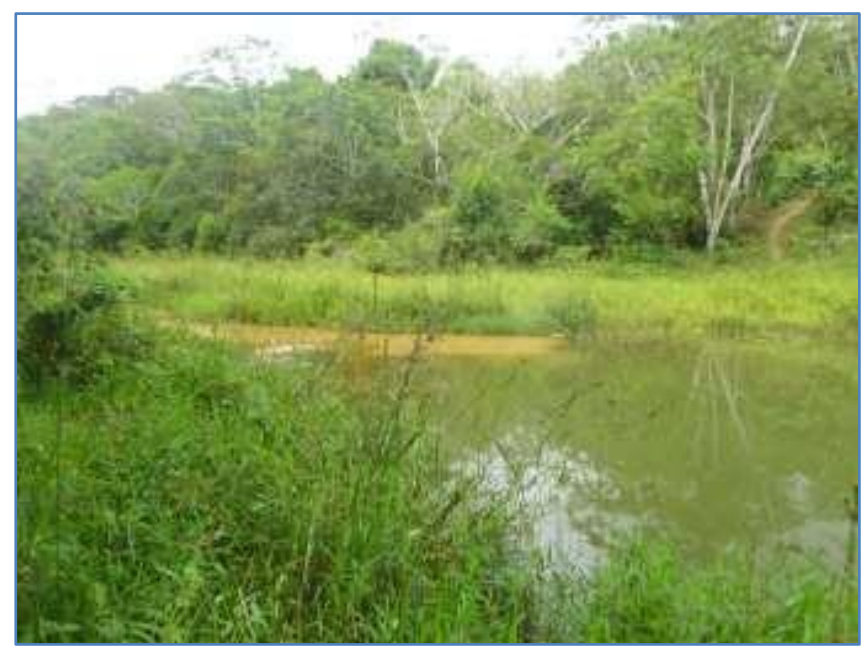

Acervo das Autoras (2012)

Na junção do rio Dangra com o Jacarecica nas proximidades do acampamento Mario Lago, há presença de lavagem de roupas e retirada de areia da margem do rio e alguns poços furados para abastecimento das famílias do assentamento. (Fig.7)

Figura 7 - Margem do rio Dangra com o Jacarecica - Município Riachuelo

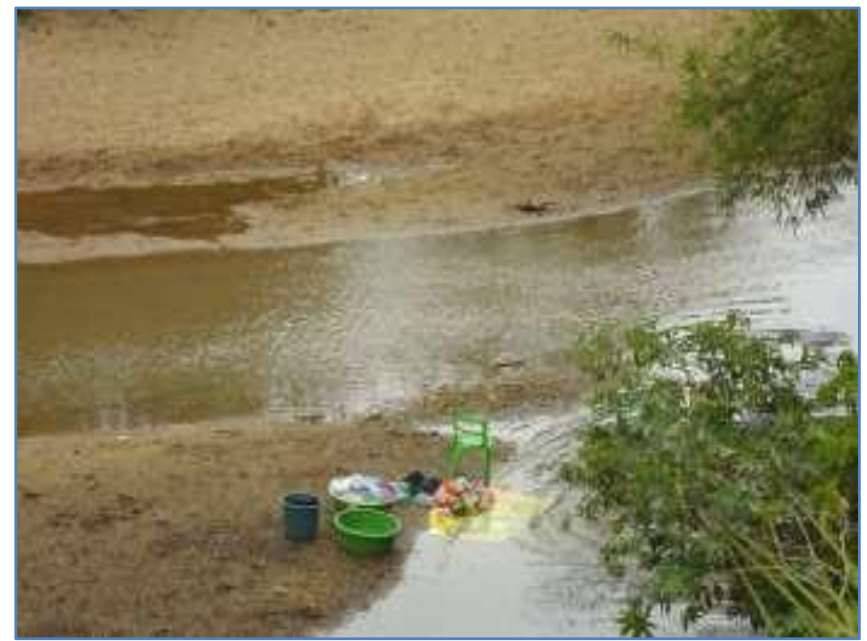

Acervo das autoras (2012)

Na foz do Jacarecica, junção com o rio Sergipe, foi registrada a retirada de areia, em vários pontos. Observou-se que a areia lavada havia sido extraída, aguardando apenas a retirada do local, com a finalidade de ser utilizada na construção civil. É empregada em obras e, junto com o cimento industrial, produz uma liga com grande capacidade impermeabilizante. (Fig.8) 
Figura 8 - Extração de areia lavada na foz- Município Riachuelo.

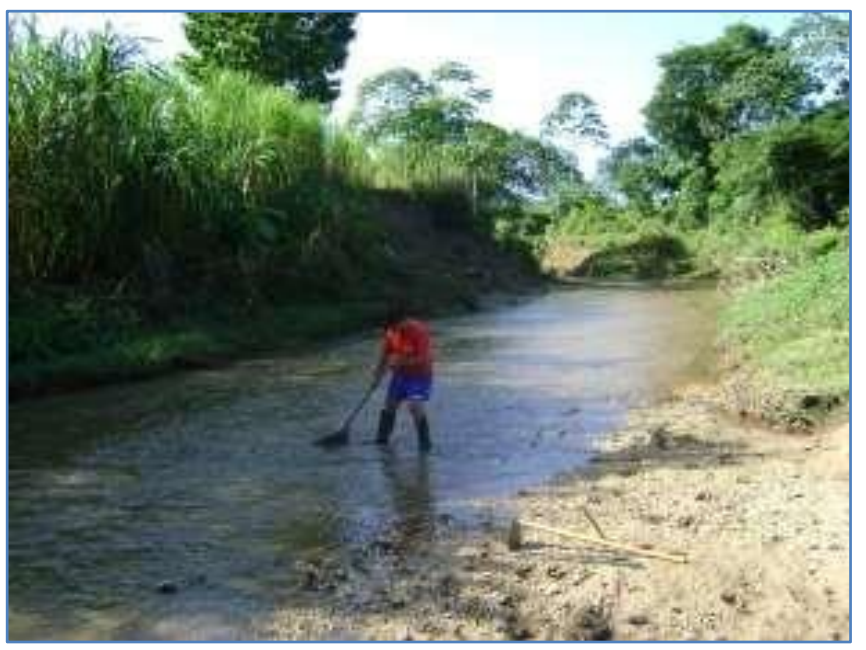

Luiz Carlos Sousa Silva (2012)

0 rio Jacarecica é fonte de abastecimento de cidades de grande e pequeno porte integrantes da bacia como um todo, e no período seco, já não consegue atender a demanda. Tal fato tem se agravado pelo uso indiscriminado da irrigação, perfuração de poços irregulares, desvio ou barramento do curso do rio, entre outros.

As barragens do Jacarecica I e II estavam com o nível de água baixo, com utilização para a pesca, irrigação e piscicultura. Com isto observou-se presença de mata ciliar apenas no Jacarecica II, ainda que insuficiente.

A partir da sanção da lei Florestal 12.727, de 17 de outubro de 2012, que prevê a continuidade das atividades agrossilvopastoris, ecoturismo e de turismo rural, entendendo a convivência necessária entre o meio ambiente e a produção rural é que dá aos agricultores familiares, um tratamento diferenciado. É autorizada a continuidade dessas atividades em áreas rurais consolidadas até 22 de julho de 2008, desde que não desmate nestes locais.

Alinhava que as propriedades rurais devem ser registradas no Cadastro Ambiental Rural- CAR, para fins de monitoramento, exigindo dos proprietários a adoção de técnicas de conservação do solo e água para minimizar os impactos ambientais causados pela presença das atividades humanas nas APP's. Contudo é obrigatória no entorno de nascentes e olhos d'água permanente a recomposição das faixas marginais de no mínimo 15 (quinze) metros, contados da borda da calha do leito regular. Sendo que a Recomposição em APP no entorno de lagos e lagos naturais, vária de acordo com o módulo fiscal da propriedade.

Os lixões são vistos a céu aberto e as cidades no entorno da bacia não possuemNa lei 12.305 de 02 de agosto de nal de Resíduos Sólidos prevê o fim dos lixões a céu aberto, a gestão do lixo de forma compartilhada entre a sociedade, poder público e iniciativa privada e a obrigatoriedade dos estados e municípios elaborarem um plano da coleta seletiva. Determinando que as prefeituras construam aterros sanitários, adequado ambientalmente onde só serão depositados resíduos sem qualquer possibilidade de reaproveitamento ou reciclagem. E a realização de estudos das áreas para instalação dos aterros sanitários buscando equilíbrio social e biótico, culminando na preservação do meio ambiente.

A maioria das bacias hidrográficas está comprometida por esgotos domésticos não tratados, dejetos de animais sem destino adequado (suinocultura, avicultura, piscicultura, bovinocultura de leite), agrotóxicos, poluição industrial, poluição por mineração, lixo urbano e rural, produtos químicos em geral e falta de proteção dos mananciais superficiais e subterrâneos. Uma das consequências disso é o custo de doenças veiculadas pela água que giram em torno de dois bilhões de reais por ano para o Brasil (FRIEDRICH, 2005).

Outro fator possível de degradação na bacia é a instalação de cerâmicas no entorno da bacia do rio Jacarecica no município de Itabaiana, uma vez que práticas de exploração mais antiga tem efeito devastador ao meio ambiente e a saúde humana. Podendo, outrossim, ocorrer a contaminação do solo, dos aquíferos e da água, provocando a erosão, a emissão de poluentes com a queima de seus produtos, perda da biodiversidade entre outros. De acordo com a (FIESP 2008) os gases emitidos durante a 
queima e a secagem da cerâmica podem contribuir com a emissão de outros poluentes para o meio ambiente, afetando também a saúde respiratória dos seres humanos com o pó proveniente das cerâmicas.

Preocupação que se soma é o destino desses resíduos sobre o solo, podendo contaminar os lençóis freáticos por meio da lixiviação dos metais pesados que com as chuvas acelerar esse impacto.

Há de considerar a presença dos matadouros nas proximidades dos corpos d' água, devido ao descarte dos resíduos sólidos gerados nas etapas do processo industrial, da limpeza dos equipamentos que constituem fonte de poluição e contaminação ao meio ambiente. 0 abatedouro visitado encontrava-se com precárias instalações e condições de higiene e não dispondo de sistema de tratamento e disposição final adequada de seus resíduos, o que torna um grande impacto ambiental para bacia. Portanto é imprescindível a fiscalização para garantir condições higiênicas sanitárias e alimentos saudáveis e a preservação do meio ambiente.

\section{CONSIDERAÇÕES FINAIS}

Impactos ambientais em bacias e sub-bacias hidrográficas reportam-se a riscos e vulnerabilidade em seus aspectos negativos. Gestão e planejamento de uso e ocupação do solo se constituem em políticas públicas de contenção de desgaste, aqui tratadas como projeção, em função do que foi visto no trabalho e registrado nos experimentos do campo.

0 processo de degradação ambiental é bastante severo, atingindo áreas protegidas por lei, necessitando, portanto, de ações imediatas, tanto dos produtores rurais como do poder publico, no sentido de repensar o modelo atual de exploração das terras e a adoção de técnicas de recuperação destas áreas. 0 desafio é superar as culturas socioeconômicas que impedem a restauração do meio ambiente.

Portanto é importante a assistência técnica aos produtores rurais aliando práticas ambientais sustentáveis, levando sempre em consideração as condições socioeconômicas da comunidade local e, assim terá êxito para definir práticas para o manejo de bacia hidrográfica. 0 que se pode projetar a curto, médio e longo prazo são as necessidades da comunidade inserida na bacia, podendo visualizar projetos de preservação e manutenção dos recursos naturais, atendendo a toda população, procurando evitar futuros conflitos. Uma vez que no rio Jacarecica as ações humanas são as principais causas de degradação dos mananciais e solos, com as queimadas, extração de areia, cultivo agrícola, pastagens etc.

Segundo Souza e Fernandes (2000), o manejo integrado de bacias deve levar em consideração o desenvolvimento da produção com preservação ambiental, adequando as necessidades antrópicas, com integração e participação na gestão de todos os atores sociais no entorno dos recursos hídricos, garantindo o desenvolvimento sustentável.

Contudo seria importante que os órgãos ambientais responsáveis mobilizassem as comunidades para discutir a importância da biodiversidade existente em suas áreas de reserva legal e promover a sua recuperação e preservação, focando principalmente na recuperação no entorno das nascentes e da mata ciliar dos rios e riachos existentes nessas áreas, valorizando suas potencialidades turísticas, socioeconômicas e medicinais, e, conscientizando a população sobre os prejuízos ambientais e sanitários provocados pelo uso de agrotóxicos e da inadequada forma de eliminação de suas embalagens, bem como das queimadas e extração desordenada dos recursos naturais.

\section{REFERÊNCIAS}

[1] COSTA, Jailton de Jesus. Transformações ambientais das restingas na planície costeira sergipana. Aracaju, 2013. Tese (Doutorado em Geografia). Núcleo de Pós-Graduação em Geografia da Universidade Federal de Sergipe.

[2] CRUZ, B.S. Diagnóstico ambiental da bacia hidrográfica do rio Uberaba. 2003, 180 p. (Tese de Doutorado), USP-Campinas/SP.

[3] CUNHA, L. H.; COELHO. M. C. N. Política dos recursos hídricos e gestão de bacias hidrográficas. IN: CUNHA. S. B.; GUERRA. A. J. T: A questão ambiental: diferentes abordagens, 2003, Rio de Janeiro: Bertrand Brasil.

[4] FEDERAÇÃO DA INDÚSTRIA DO ESTADO DE SÃO PAULO (FIESP) Guia Técnico Ambiental Da Indústria de Cerâmica (2008).

[5] GONÇALVES, Carlos Walter Porto. Os (dês)caminhos do meio ambiente. 14ํae ed. São Paulo: Contexto, 2006. (cap. V e VI). 
[6] LAGO, André Aranha C. do. AGENDA 21. Disponível em: <http://pt.wikipedia.org/wiki/ECO- 92>. Acessado em 29/02/2013.

[7] LEFF; Enrique. A construção da racionalidade ambiental. In: Racionalidade Ambiental: a reapropriação social da natureza. Tradução: Luís Carlos Cabral. Rio de Janeiro: Civilização Brasileira, 2006.

[8] MENDES, I. A. Dinâmica Ambiental e Preservação dos Recursos Naturais. IN:MENEZES, A. V. C.;PINTO,J.E.S.S: Geografia 2001,Aracaju:NPGEO/UFS,2000.

[9] MENDONÇA, Francisco de A. \& SPRINGER, Kalina Salaib. A(s) ideia(s) de natureza na Geografia: elementos para a compreensão e debate. In: COSTA, Jailton de Jesus, SANTOS, Cleane Oliveira dos, SANTOS, Marcelo Alves dos, ALMEIDA, Maria Geralda de, SOUZA, Rosemeri Melo e. (ORGS). Questões geográficas em debate. São Cristóvão: Editora UFS, 2012, $184 \mathrm{p}$.

[10] NASCIMENTO, Flavio Rodrigues. Degradação e Desertificação no Nordeste Brasileiro: o contexto da bacia hidrográfica do rio Acaraú-Ceará. 2006(Tese de Doutorado), UFF- Niterói/RJ.

[11] TEIXEIRA, W. et. al. Recursos Hídricos. IN:HIRATA.R: Decifrando a Terra,2003,São Paulo; Oficina de Textos.

[12] TOMASONI, Marco A., PINTO, Josefa Eliane S. de S. e SILVA, Heraldo P. da. A questão dos recursos hídricos e as perspectivas para o Brasil. GEOTEXTOS, Salvador: Revista da Pós-Graduação em Geografia da Universidade Federal da Bahia, Ano 2009 - vol.5 - n.2, dezembro de 2009.

[13] BRASIL. Presidência da República. Código Florestal Disponível em: www.planalto.gov.br. Acessado em $12 / 06 / 2013$. 


\title{
CAPITULO 08 \\ Riscos ambientais no uso de agrotóxicos nos perímetros irrigados Jacarecica I e II
}

\author{
Ismeralda Maria Castelo Branco do Nascimento Barreto \\ Josefa Eliane Santana de Siqueira Pinto
}

\section{INTRODUÇÃO}

O foco da problemática dos agrotóxicos, e seu uso contínuo e indiscriminado na agricultura, se encontram em impactos socioambientais, nos padrões de produção e de consumo agrícola, além das dificuldades de implementação da logística reversa das embalagens consumidas, causando danos ao meio físico e a população.

Esta abordagem se apresenta como observações resultantes de revisão bibliográfica sobre as ações impactantes socioambientais dos agrotóxicos na agricultura desenvolvida nos perímetros irrigados Jacarecica I e Jacarecica II na sub-bacia do Jacarecica, em Sergipe.

A relevância do artigo se justifica pela necessidade de observar a situação do uso destes produtos nos cultivos alimentares e seus possíveis impactos socioambientais na área de abrangência da sub-bacia hidrográfica.

Entende-se que a agricultura brasileira, buscando atender aos padrões de produção voltados para a agricultura comercial, alterou a política agrícola de governo, cuja meta tem sido alcançar níveis elevados de produtividade em suas lavouras de hortifrutigranjeiros no país por décadas.

O setor agrícola brasileiro, buscando obter produção e produtividade, introduziu em áreas plantadas insumos modernos e rentáveis economicamente, mas de elevado impacto tanto na natureza que vai da água, do solo e do ar, ao agricultor e ao consumidor destes produtos agrícolas.

Os agrotóxicos são classificados de acordo com seu poder de ação como: inseticidas, fungicidas, herbicidas, reguladores e inibidores de crescimento etc. compostos significativamente utilizados para eliminar organismos, ou alvos biológicos, que atacam a produção agrícola. Estes produtos tem mercado concentrado e, conforme Pelaez et al (2010), 70\% são controlados por Syngenta, Bayer, Monsanto, DuPont, Dow e BASF, as seis maiores empresas do ramo.

Considera-se a produção segmentada, devido às especificidades dos produtos, de efeitos tóxicos que variam com o metabolismo, pela diversidade de organismos como: insetos, fungos, plantas daninhas, ácaros e roedores, como também da interação desses organismos com os cultivos agrícolas (PELAEZ et al, 2010).

Com base no exposto, vê-se a literatura associada à realidade local nos aspectos relacionados à produção agrícola; ao uso de agrotóxicos e seus impactos socioambientais; nos documentos regulatórios e institucionais contribuidores da fundamentação e estruturação do artigo.

A literatura mostra que o uso de agrotóxicos na agricultura é um processo que se desenvolveu em escala global a partir, principalmente, da Revolução Verde, desde a década de sessenta (MMA. 2010; BOTELHO e LIMA, 2011) aos dias atuais, no sentido de aumentar a produtividade na agricultura alimentar, atendendo não apenas a demanda crescente da população, mas por outro lado, ao processo de desenvolvimento e difusão de tecnologias (SOARES, 2010).

Por sua vez, o aumento do consumo de fertilizantes em 1994 eleva-se, enquanto o uso de máquinas e equipamentos na agricultura diminui (Zandonadi, 1996 apud LUCENA e SOUZA, 2001) e, desencadeiam por outro lado, problemas ambientais e sérias transformações sociais no setor agrícola (BOTELHO e LIMA, idem). 
0 grande desafio da agricultura tem sido o aumento de sua produtividade média de alimentos para suprir a demanda da população, sempre crescente em escala planetária. Lucena e Souza (2001) entendem que basta observar o horizonte a ser alcançado de quatro bilhões de toneladas de grãos no ano de 2025, enquanto na década de 1990 a produção foi de 2,5 toneladas por hectare.

Todavia, as inter-relações entre agricultores e agricultoras, produção alimentar e disponibilidade de solo, água e ar, assim com a geração de resíduos nos alimentos, causam também efeitos negativos no meio ambiente, afetando a saúde e a segurança alimentar e nutricional da população (Adissi \& Sobreira, 1999 apud BOTELHO E LIMA, 2011).

Ainda, a agricultura brasileira transformou-se, principalmente na década de 1990, com a abertura econômica, oriunda da implantação do Plano Real via elevação do nível de renda no país, oportunizando sua circulação e ampliação no setor rural (LUCENA E SOUZA, 2001).

Reitera-se que o crescimento da agricultura no Brasil está diretamente relacionado às políticas relativas a fertilizantes, agrotóxicos e máquinas agrícolas, tendo em vista a elevação em $20 \%$ ao ano no consumo de fertilizantes que passou de 300 mil toneladas em 1965 para quatro milhões de toneladas em 1980 (Rezende, 1999 apud LUCENA e SOUZA, 2001).

Neste período, diz Lucena e Souza (op. cit.) que a prioridade dada pelo governo ao setor agrícola oportunizou sua expansão na década de 70, e retração elevada ao longo da década de 80 e, uma nova expansão em 1994, com o advento do Plano Real e a da produção interna de fertilizantes da ordem de 12 milhões de toneladas, e um consumo médio de $261 \mathrm{~kg} / \mathrm{ha}$ contra $185 \mathrm{~kg} / \mathrm{ha}$ no final da década de 80 (Zandonadi, 1996 apud LUCENA e SOUZA, 2001).

Em escala global o consumo de fertilizantes em 1998 totalizou 14,7 milhões de toneladas, enquanto em 1997 foi de 13,8 milhões de toneladas. Todavia, a desvalorização do Real em janeiro de 1999 provoca uma elevação de preços pagos por fertilizantes pelos agricultores, alterando o seu emprego na agricultura (op. cit.).

Consideram os autores que, ao cumprirem o papel de proteção dos cultivos agrícolas de pragas, doenças e ervas daninhas, de forma frequente e até incorretamente, causam riscos de contaminação nos solos agrícolas, nas águas superficiais e subterrâneas e em cadeia. Spadotto et al (2004) referem-se ao risco de intoxicação ocupacional em trabalhadores e produtores rurais.

A capacidade de suporte, segundo Junk (1995) "é a capacidade de um ecossistema ou de uma região para suportar sustentadamente um número máximo de população humana sob um dado sistema de produção" (p.52), compreendendo, todos os que utilizam recursos renováveis, no caso a agricultura.

Assegura Junk ainda (op. cit) que outros fatores determinantes da capacidade de suporte de ecossistemas são: clima, solos, geomorfologia, e um conjunto de espécies vegetais e animais disponíveis, cujo desenvolvimento sustentável é alcançado pelas inter- relações entre tais fatores. Porém, a otimização da capacidade de suporte de ecossistemas pode ser alcançada via manejo, redução ou eliminação de fatores limitantes com o uso de tecnologias e intelecto humano.

A produção agrícola pode ter a água como um fator restritivo, em determinado uso da água, tal como se observa em projeto de irrigação desenvolvido em Israel, no qual se transfere água adicional há um ecossistema onde existe água em excesso (Idem).

0 impacto da poluição pelo uso de agrotóxicos relaciona-se diretamente com as dimensões espaço e tempo, do qual o meio físico ar, solo e água são transportadores de poluentes. A poluição migra através do lançamento de rejeitos gerados em determinada região onde seus efeitos são sentidos também em outras regiões, até distantes. Quanto a dimensão tempo, a poluição pode ser percebida por efeito cumulativo, onde o poluente isolado ou em contato com outros entra na cadeia alimentar e, dependendo do grau de contaminação atinge vegetais e animais. Estes rejeitos lançados de forma inadequada no meio físico, sentidos pela população, causam poluição cumulativa cujos efeitos são sentidos no longo prazo.

No Brasil o mercado de agrotóxicos engloba 107 empresas produtoras; o maior do mundo, com uma fatia de $16 \%$ do mercado mundial. Em 2009, foram vendidas mais de 780 mil toneladas de produtos em todo o país, e ainda ocupa a sexta posição no ranking mundial de importação de agrotóxicos. A entrada desses produtos no Brasil aumentou 236\% entre 2000 e 2007. Pelaez afirma, no estudo "Monitoramento do Mercado de Agrotóxicos", que a consolidação do Brasil como o maior mercado do mundo de agrotóxicos é também o que tem o maior ritmo de expansão. 
Ao longo desta década, o mercado brasileiro cresceu $176 \%$, quase quatro vezes mais do que a média mundial. Ainda, as dez maiores empresas do setor de agrotóxicos concentram mais de $80 \%$ das vendas no Brasil. Tal cenário aponta, por outro lado, que os agrotóxicos constituem-se na segunda maior causa de intoxicação no Brasil, depois de medicamentos, conforme o Ministério da Saúde. Há que se considerar que, em 2008, o país ultrapassa os Estados Unidos e assume a liderança no consumo de agrotóxicos no mundo. De acordo com a Agência Nacional de Vigilância Sanitária (ANVISA) foi dado o sinal vermelho para frutas, verduras e legumes que estão chegando contaminados à mesa dos consumidores.

Uma pesquisa do Programa de Análise de Resíduos de Agrotóxicos em Alimentos (PARA), realizada em vinte e seis estados brasileiros em 2009, demonstrou que foram encontrados, em amostras de alimentos, resíduos de agrotóxicos proibidos, acima do limite permitido. Ainda, grande parte das frutas, verduras e legumes em diversos pontos de venda do Brasil não tem a origem identificada.

Segundo a avaliação da ANVISA desde 2008 que há, com regularidade, quatorze ingredientes ativos utilizados na composição de mais de 200 agrotóxicos, muitos dos quais são proibidos em diversos países do mundo. Todavia, a indústria brasileira de agrotóxicos entrou na justiça questionando a ação. Assim, continuam chegando ao mercado nacional produtos proibidos tanto na União Europeia, a exemplo do Acefato, quanto nos Estados Unidos, Canadá, Japão e na China.

A partir dessa pesquisa bibliográfica e projeção dos resultados foram obtidos dados e análises específicas sobre a realidade da sub-bacia em estudo, referente ao uso dos agrotóxicos na agricultura, que se apresenta como reflexão sobre novos rumos para as políticas públicas de gestão agroecológica para Sergipe.

0 rio Jacarecica constitui-se em um recurso hídrico significativo em sua área de tem a função de abastecer parte significativa do mercado de feiras livres, especialmente com cultivos de hortifruticultura, daí sua importância. É mister ressaltar que na sua foz está o município de Aracaju, polarizador de atividades urbanas que lhe confere a importância de ser a capital sergipana.

A relevância do estudo destaca a agricultura, tendo em vista ser a principal atividade econômica da subbacia hidrográfica do rio Jacarecica, que abastece os perímetros de irrigação por aspersão, Jacarecica I e Jacarecica II (Figura 1), cujos cultivos são desenvolvidos por pequenos agricultores na produção de cereais, frutas, verduras e hortaliças, como mandioca, batata doce, manga, tomate, feijão e cebola, além de amendoim, quiabo, repolho, pepino, banana etc.

Área localizada na região do Agreste Central, considerada como centro hortifrutigranjeiro e celeiro principal do Estado, que abastece grande parte do território de Sergipe. Também deve relevar seu papel no abastecimento do município de Itabaiana, um dos maiores e importantes economicamente do Estado.

Diante deste contexto o estudo no âmbito da bacia hidrográfica resultou em observações das condições de uso de agrotóxicos, a incidência de doenças humanas; os impactos no solo e na água, as perdas econômicas e, como superar o desafio de produzir alimentos com qualidade socioambiental. Consideram-se entre outros fatores, as condições de clima, solo, água, aspectos econômicos, de saúde e ambientais da região.

Este artigo está estruturado em três seções: na primeira, abordam-se os marcos históricos e conceituais relacionados aos agrotóxicos e ao seu uso na agricultura brasileira. $\mathrm{Na}$ segunda seção, os marcos regulatórios. E na terceira seção, observa-se o uso de agrotóxicos nas áreas dos projetos de irrigação Jacarecica I e Jacarecica II.

\section{ANTECEDENTES HISTÓRICOS E CONCEITOS}

O uso de substâncias orgânicas e inorgânicas para melhorar o rendimento de cultivos agrícolas vem desde a antiguidade clássica quando os gregos e romanos utilizavam arsênio no controle de insetos (BOZIKI et. al., 2011), enquanto na China por volta de 2000 anos atrás, os inseticidas naturais eram à base de extrato de piretrina das flores do crisântemo (Chrysanhemun sp). Segundo Marques (2005) as tendas no deserto de armazenamento de cereais eram protegidas com pó de piretro, colocados sobre os grãos ou suas flores eram colocadas na entrada das tendas. Cita-se ainda a utilização de outros compostos vegetais por suas propriedades inseticidas, como a raiz de timbó, através de seus extratos nicotina e retinona.

Na Europa do século XIX, extratos vegetais e compostos inorgânicos eram aplicados no controle de pragas e doenças tanto na agricultura quanto na pecuária. 0 avanço no uso de produtos químicos em 
escala mundial na proteção de plantios contra as pragas e doenças deu-se no final do século e nas três primeiras décadas do século XX, com o uso dos compostos inorgânicos a base de flúor, arsênico, mercúrio, selênio, chumbo, bórax, sais de cobre e zinco (BOZIKI, 2011; MARQUES, 2005).

Desde a Primeira Guerra Mundial que as substâncias agrotóxicas são utilizadas, porém alteradas e igualmente empregadas na Segunda Guerra Mundial. Lutzenberger apud Boziki (2011) comentam que os grandes estoques de veneno do pós-guerra, aliados a elevada capacidade de produção instalada nos parques industriais, proporcionaram aos químicos lembrarem "que o que mata gente também poderia matar insetos".

O desenvolvimento da síntese orgânica e a estruturação da base tecnológica, conforme Spadotto et al (2007), assim como do padrão tecnológico da agricultura moderna contribuíram para dinamizar a indústria mundial de agrotóxicos.

Todavia, o marco das alterações nas técnicas de controle fitossanitário das culturas agrícolas foi a descoberta em 1939 das propriedades inseticidas do organoclorado Dicloro Difenil Tricloetano (DDT) sintetizado inicialmente por Othmar Zeidler em 1873. Porém foi Paul Muller que descobre suas propriedades inseticidas em 1939, cuja importância foi registrada ao receber o Prêmio Nobel em 1948. Ainda, 0 estímulo crescente na síntese da química orgânica com propriedades biocidas, no qual a Alemanha na tentativa de produzir gases tóxicos para uso na guerra e fez a síntese do organofosforado. Enquanto os Estados Unidos através do desenvolvimento de suas pesquisas químicas desenvolveu substâncias a serem aplicadas para destruir áreas de colheitas inimigas (MARASCHIN, 2003).

Assim, após a guerra estabeleceu-se um novo padrão na agricultura cuja base tecnológica assentou-se no uso de agroquímicos como agrotóxicos, fertilizantes e corretivos, além da mecanização, dos cultivares de elevada produtividade e as técnicas de irrigação que a partir da década de 1960 expande-se para as regiões do Sul do Planeta, com a chamada Revolução Verde (SPADOTTO et al, 2004).

A expansão industrial dos agrotóxicos começou a ser reavaliada pela comunidade técnica internacional em seus aspectos de segurança e eficácia a partir de 1962, após as denúncias de Rachel Carson, no livro Primavera Silenciosa (Silent Spring), que aborda o problema de persistência e de danos ambientais causados pelo uso de agrotóxico e, seus riscos e benefícios, com ênfase no DDT. Ocorre que, apenas na década seguinte é que a agência ambiental americana (Environmental Protection Agency EPA) retira de circulação produtos sintéticos ou os mantêm sob-restrição de uso, em decorrência de comprovação dos malefícios à saúde e ao ambiente (MARQUES, 2005).

Os agrotóxicos cumprem o papel de proteger as culturas agrícolas das pragas, doenças e plantas daninhas, mas por outro lado podem oferecer riscos à saúde humana e ao ambiente, tanto pelo uso frequente, quanto pelo uso incorreto. Os riscos estão voltados a contaminação dos solos agrícolas, das águas superficiais e subterrâneas, dos alimentos com apresentação de efeitos negativos citados em Spadotto et al (2004) que se dá em:

"organismos terrestres e aquáticos e de intoxicação humana pelo consumo de água e de alimentos contaminados, assim como o risco de intoxicação ocupacional de trabalhadores e produtores rurais (p.7)".

No Brasil, a terminologia de defensivos agrícolas, produtos fitossanitário, pesticidas e agrotóxicos é conhecida, no qual o termo agrotóxico é recorrente na literatura e na legislação do país. Neste artigo, seguindo Spadotto et al op. cit., agrotóxico é o termo utilizado e que agrega as seguintes categorias: inseticidas, acaricidas, nematicidas, fungicidas, bactericidas e herbicidas.

Somente a partir de 1943 é que os agrotóxicos organossintéticos e suas primeiras amostras de DDT foram introduzidos no Brasil (MARQUES, 2005; BORGES FILHO, sd), com intenso uso ao longo de décadas, segundo o serviço de defesa sanitária vegetal, mas apenas em 1985, através de portaria do Ministério da Agricultura, define a proibição dos agrotóxicos organoclorados no país.

\section{CONCEITOS FUNDAMENTAIS}

O termo agrotóxico tem sido oralmente utilizado e divulgado em mídia, o que o torna conhecido da população leiga, todavia, é necessário conhecer seus significados, pois agrotóxico segundo Maraschin (2003) é também conhecido por pesticida, biocida, defensivo agrícola e praguicida, classificados em diferentes grupos de substâncias químicas. 
Pesticidas são materiais orgânicos tóxicos ou substâncias com potencial de controle direto de um organismo indesejável, que pode matar diretamente. Passos (2012) afirma que o processo metabólico dos organismos vivos pode ser bloqueado por pesticidas. Portanto, os pesticidas têm impacto significativo sobre a saúde humana, que pode se processar pela ingestão de alimentos contaminados.

Dentre os pesticidas existentes no mercado, as três categorias mais usadas são os inseticidas, utilizados para matar os insetos; os herbicidas para matar as plantas e; os fungicidas, usados no controle de fungos.

Os organoclorados são pesticidas ou compostos orgânicos que contém o cloro em sua estrutura e em geral são clorobenzeno, do ciclo-hexano ou do ciclodieno, de estrutura química do organoclorado BHC hexaclorociclohexano, dos quais cita-se: Aldrin, Endrin, Dieldrin, BHC, DDT, Endossulfam, Heptacloro, Lindano, Mirex. São produtos carcinogênicos, tóxicos, de contaminação crônica e, persistentes no meio ambiente (PASSOS, 2012). Ou seja, conforme Faria (2000) estas substâncias permanecem presentes na cadeia alimentar, através do solo, da água e da atmosfera, mantendo relação com a flora e fauna ou a biodiversidade do ecossistema envolvido.

Dentre os alimentos contaminados por pesticidas, os dez alimentos mais contaminados por agrotóxicos, entre as amostragens analisadas pela Agência de Vigilância Sanitária (ANVISA) com uma frequência maior foram os alimentos, conforme Tabela 1 :

Tabela 1 - Alimentos contaminados por pesticidas segundo amostragens da Agência de Vigilância Sanitária em 2012

\begin{tabular}{c|c|c} 
NNo $^{-}$ & ALIMENTOS & PERCENTUAL (\%) \\
1 & Pimentão & $80,0 \%$ \\
\hline 2 & Uva & $56,40 \%$ \\
\hline 3 & Pepino & $54,80 \%$ \\
\hline 4 & Morango & $50,80 \%$ \\
\hline 5 & Couve & $44,20 \%$ \\
\hline 6 & Abacaxi & $44,10 \%$ \\
\hline 7 & Mamão & $38,80 \%$ \\
\hline 8 & Alface & $38,40 \%$ \\
\hline 10 & Tomate & $32,60 \%$ \\
\hline
\end{tabular}

Os pesticidas organofosforados compreendem os compostos orgânicos à base de fósforo, derivados do ácido fosfórico, do ácido tiofosfórico ou do ácido ditiofosfórico e que contém sem exceção fósforo pentavalente, ligado ao oxigênio ou enxofre. São organofosforados parationa metílica encontrada nos produtos: Folidol, Azodrin, Malationa, Diazinona, Dimetoato, Nuvacron, Tamaron, Rhodiatox. Substâncias de alta degradabilidade, alta toxidade aguda, lipossolúveis, inibidores da acetilcolinesterase e são os mais usados na agricultura (PASSOS, 2012).

Inicialmente, Spadotto (2004) se refere que a avaliação ambiental estava voltada à classificação da periculosidade de cada agrotóxico, ou seja, dos dados ecotoxicológicos do produto. Atualmente, a avaliação ambiental considera os riscos de ecotoxidade, exposição, e os efeitos que cada produto pode causar nos organismos em exposição.

A classificação toxicológica dos pesticidas orgânicos tóxicos mencionados acima segue os valores de DL50 oral aguda. No Quadro 1 a seguir se observam os malefícios potenciais contidos. 
Quadro 1 - Classificação Toxicológica Ambiental dos Agrotóxicos baseada nos valores de DL50 Oral Aguda

\begin{tabular}{l|c|c|l}
\multicolumn{1}{c}{ Classificação } & Rótulo & $\begin{array}{c}\text { DL50 } \\
(\mathrm{mg} / \mathrm{kg})\end{array}$ & Dose capaz de matar uma pessoa adulta \\
I - Extremamente tóxico & Vermelho & Até 5 & 1 pitada - algumas gotas \\
\hline II - Altamente tóxico & Amarelo & $5-50$ & 1 colher de chá - algumas gotas \\
\hline III - Medianamente tóxico & Azul & $50-500$ & 1 colher de chá - 2 colheres de sopa \\
\hline IV - Pouco tóxico & Verde & Acima 500 & 2 colheres de sopa - 1 copo \\
\hline
\end{tabular}

Os produtos orgânicos tóxicos hidrocarbonetos policíclicos aromáticos (HPAs), compreendem uma família de compostos químicos caracterizados por possuírem dois ou mais anéis aromáticos condensados, dos quais em humanos, seus derivados podem ser absorvidos através da pele, por ingestão ou por inalação, rapidamente distribuída pelo organismo. As principais fontes são: processos de combustão de material orgânico (particularmente a exaustão de motores a diesel ou a gasolina), a queima de carvão, a exaustão de plantas de incineração de rejeitos, a fumaça de cigarro além de vários processos industriais como, por exemplo, a produção de alumínio e a gaseificação do coque. (PASSOS, op. cit.)

Passos (2012) afirma que os produtos orgânicos tóxicos polychlorinated biphenyls (PCBs) bifenilas policloradas, são hidrocarbonetos clorados que contém benzeno unidos por uma ligação simples de carbono-carbono, com cloro. São substâncias altamente resistentes à degradação, capaz de bioacumular e biomagnificar na cadeia trófica com ampla distribuição ambiental, onde o transporte é o principal mecanismo para a dispersão global.

O uso e a produção de PCBs foram severamente restritos ou banidos em muitos países a partir da década de 70, com a data limite para o seu uso expirando em 2025. O Brasil proibiu a fabricação, a comercialização e o uso de PCBs, através da Portaria Interministerial no 19, de 2 de janeiro de 1981. Entretanto, permite o funcionamento de equipamentos já instalados, até sua substituição integral ou a troca do fluído dielétrico por produto isento de PCBs. Os PCBs são utilizados em sistemas de transferência de calor, fluidodielétrico em transformadores e capacitadores, fluídos, lubrificantes, plastificantes para tinta e outras. No Brasil, as misturas de PCBs foram comercializadas com o nome de Ascarel (WHO 1976, Safe 1986, Hoivik \& Safe 1998 apud PASSOS, 2012).

Ainda sobre os produtos orgânicos tóxicos, o Ministério do Meio Ambiente (2009), reitera doze Produtos Orgânicos Persistentes (POPs), classificados segundo as Convenções de Basiléia, Roterdã e Estocolmo, a) pesticidas: Aldrin, clordano, mirex, dieldrin, endrin, heptacloro, BCH e o toxafeno; b) produtos de uso geral: DDT, PCBs (bifenilas policloradas) e; c) produtos não intencionais: Dioxinas, furanos (PASSOS, 2012). Os efeitos provocados são doenças graves, como o câncer, além de má-formação em seres vivos, muitas vezes encontrados em locais distantes das fontes emissoras, portanto, é um problema de caráter global. A maioria dos 12 compostos listados foi banida, ou teve seu uso restringido em boa parte do mundo, reduzindo o impacto econômico da ratificação da convenção e facilitando sua entrada em vigor; O Brasil, por exemplo, não produz diretamente nenhum dos doze compostos, mas importa três deles para uso industrial. Entretanto, as dioxinas e os furanos, por serem produzidos de forma não intencional, demorarão mais a ser eliminados (Idem).

O principal problema dos POPs caracteriza-se segundo o autor por ser pouco solúveis em água, mas são solúveis em gorduras. Os animais têm um ótimo sistema de eliminação de toxinas solúveis em água, que são expelidas na urina, mas não possuem mecanismo eficaz de eliminação de substâncias pouco solúveis na água.

Tal efeito é intensificado em animais ditos superiores, que se alimentam das gorduras de outros animais. Podem percorrer longas distâncias pelas correntes aéreas e oceânicas. Ou seja, eles não contaminam só o local de emissão, mas também locais distantes e remotos, cadeias montanhosas e oceanos; Evaporam rapidamente em regiões quentes e lentamente em locais frios.

Ainda, sobre o termo agrotóxico, no Brasil a Lei no 7.802, de 11 de julho de 1989, diz que: 


\begin{abstract}
“agrotóxicos são os produtos e os agentes de processos físicos, químicos ou biológicos, destinados ao uso nos setores de produção, no armazenamento e beneficiamento de produtos agrícolas, nas pastagens, na proteção de florestas, nativas ou implantada, e de outros ecossistemas e também de ambientes urbanos, hídricos e industriais, cuja finalidade seja alterar a composição da flora e da fauna, a fim de preservá-las da ação danosa de seres considerados nocivos, bem como as substâncias e produtos empregados como desfolhantes, dessecantes estimuladores e inibidores do crescimento" (BRASIL, 1989).
\end{abstract}

Sobre a definição brasileira Maraschin (2003) afirma que excluem-se os fertilizantes ou nutrientes, drogas veterinárias, amadurecedores, aditivos alimentares e antibióticos.

Assim, agrotóxico é também chamado de defensivo agrícola, pesticida, praguicida, além de outras citadas. Segundo Rocha, et al. (1992):

"Trata-se de substâncias químicas, naturais ou sintéticas e se destinam a matar ou controlar insetos, fungos, bactérias ou outros tipos de pragas prejudiciais à lavoura ou à pecuária."

Agrotóxico é um termo conhecido na sociedade contemporânea, porém sua complexidade no processo de gestão ambiental requer tratamento interdisciplinar tendo em vista suas interfaces acadêmicas e científicas, tal como exige a dinâmica ambiental no esforço complementar e integrado de visões tanto generalista quanto especialista de fenômenos complexos.

"somente o conhecimento aprofundado, adquirido pela prática da interdisciplinaridade, aliado à capacidade de discernimento e de simplificação consciente podem resultar no avanço metodológico, científico e tecnológico consciente".

Embora secularmente utilizado na agricultura, somente a partir da década de sessenta é que a problemática dos agrotóxicos passa a ter o viés ambiental no contexto de discussão de fóruns internacionais, tal como o Clube de Roma em 1968, visando à adoção de políticas de proteção a saúde pública e o meio ambiente (MARQUES, 2005).

Desde então surge à necessidade de criar organismos responsáveis, normas e padrões de controle de qualidade e estabelecimento de critérios, para disciplinar o uso e igualmente atender tanto as prioridades nacionais, os fatores econômicos, à segurança e saúde pública considerando o conhecimento tecnológico.

\title{
4 GESTÃO AMBIENTAL REGULAÇÃO DOS AGROTÓXICOS
}

Para implementar a gestão das substâncias químicas em escala global criam-se as agências internacionais com sugestões de critérios permissíveis de uso nos Estados Unidos e Europa como a Agência de Proteção Ambiental Americana, Environmental Protection Agency (EPA), bem como a Agência Ambiental Européia, European Environmental Agency (EEA). Entretanto, sobre a definição de qualidade de água potável em escala mundial, a sugestão é de responsabilidade da Organização Mundial de Saúde (OMS).

Segundo o Ministério do Meio Ambiente (MMA), os fundamentos do manejo global ecologicamente saudável das substâncias químicas tóxicas e perigosas estão indicadas no Capitulo 19 da Agenda 21 Global, desenvolvidos em três Convenções que juntas tratam do manejo de substâncias químicas, tais como:

- Convenção de Basiléia define o Controle do Movimento Transfonteiriço de Resíduos Perigosos e seu Depósito;

- a Certos Agrotóxicos e Substâncias Químicas Perigosas, Objeto de Comércio Internacional e;

- Convenção de Estocolmo, sobre Poluentes Orgânicos Persistentes (POPs).

Tanto a Convenção de Basiléia, quanto a Convenção de Estocolmo em Genebra são patrocinadas pelo Programa das Nações Unidas para o Meio Ambiente (PNUMA) e a Organização das Nações Unidas para a Agricultura e a Alimentação (FAO). 0 secretariado da Convenção de Roterdã se localiza em Genebra e em Roma (MMA, 2009), este é o arcabouço do sistema internacional de segurança química, cuja missão de gestão é a redução de riscos de acidentes pelo uso inadequado das substâncias do acordo. 
Reiteram as convenções que o uso de produtos químicos visa alcançar os objetivos sociais e econômicos da comunidade mundial e que as melhores práticas modernas podem ser utilizadas com boa relação custo eficiência e com elevado grau de confiança, desde que os parâmetros sejam atendidos, que haja o monitoramento e a fiscalização por técnicos e agrônomos especialista tal como consta na legislação brasileira, e na Agenda $21 \mathrm{Global}$, assinada por todos os países presentes na Conferência Mundial para o Meio Ambiente e o Desenvolvimento no Rio de Janeiro, em 1992.

O Capítulo 20, da Agenda 21, trata do manejo ambientalmente saudável dos resíduos perigosos e, inclui a prevenção do tráfico internacional ilícito desses resíduos perigosos. Desde 1985, o PNUMA e a FAO começaram a desenvolver a promoção de programas voluntários e troca de informações, para Código Internacional de Conduta sobre Distribuição e Uso de Agrotóxicos, enquanto o PNUMA em 1987 estabeleceu as Diretrizes de Londres para a Troca de Informações sobre Substâncias Químicas Objeto de Comércio Internacional, cujo desdobramento é o Procedimento de Consentimento Prévio Informado (PIC), em 1989, programa que garante aos governos a obtenção de informação necessária sobre substâncias químicas perigosas, para avaliar os riscos e tomar decisões sobre as importações de substâncias químicas objeto de comércio internacional, da

A segurança química global sobre os Poluentes Orgânicos Persistentes (POPs) tem como instrumento de regulação a Convenção de Estocolmo, realizada na Suécia em 2001, com assinatura de 92 países e a Comunidade Européia, ratificada no Brasil em 16 de Junho de 2004, regulamentada em Decreto Executivo no 5.472 , de 20 de junho de 2005.

Trata-se de determinações e obrigações a serem adotadas pelos países parte relacionadas ao controle em todas as etapas do ciclo de vida das 12 substâncias POPs, que envolve a produção, importação, exportação, disposição e uso destas substâncias classificadas, inclusive define sua eliminação total.

O Programa das Nações Unidas para o Meio Ambiente (PNUMA) desde 1995 solicitou a avaliação dos seguintes produtos: aldrin, DDT, dieldrin, dioxinas, endrin, furanos, hexaclorobenzeno, heptacloro, mirex, PCBs e toxafeno, no Fórum Intergovernamental sobre Segurança Química (FISQ), para recomendações em escala global.

No Brasil a execução da gestão para a proteção ambiental distribui-se as responsabilidades entre os Ministérios da Agricultura; da Saúde e; do Meio Ambiente. Órgãos de gestão, controle, monitoramento e fiscalização, com atuação focada em atender as diretrizes internacionais e nacionais vigentes, recepcionadas na Constituição Federal de 1988, cuja tutela ambiental é administrativa, civil e penal (CHIUVITE, 2010).

A gestão ambiental brasileira rege-se na Lei oㅡ 6.938, de 31 de agosto de 1981, que regula a Política Nacional de Meio Ambiente, define instrumentos legais, técnicos, científicos, políticos e econômicos, institui o Sistema Nacional de Meio Ambiente (SISNAMA), que trata da estruturação e articulação de órgãos entre as esferas de poder para implementá-la e executá-la, dos quais o Conselho Nacional de Meio Ambiente (CONAMA), é responsável pela elaboração de normas e padrões compatíveis com o meio padrões de qualidade ambiental estão estabelecidos em resoluções do Conama relativas ao ar, à água, ao solo e aos níveis de ruído.

Produzir, exportar, importar, comercializar e utilizar os agrotóxicos deve-se previamente registrá-los no Instituto Brasileiro do Meio Ambiente e dos Recursos Naturais Renováveis (IBAMA), órgão responsável pela avaliação do potencial de periculosidade ambiental de todos os agrotóxicos, de competência federal, atende as diretrizes e exigências dos órgãos de setores da saúde, do meio ambiente e da agricultura no mesmo âmbito (IBAMA, 2009).

A regulação dos agrotóxicos no Brasil tem acompanhado a dinâmica do setor industrial de agrotóxicos e igualmente do setor agropecuário, visando o estabelecimento de regras para que o setor busque eficiência e garantias de minimizar os riscos inerentes do seu uso, manuseio e consumo. Cabe ao Ministério da Agricultura, Pecuária e Abastecimento que realiza a avaliação do desempenho agronômico do produto; enquanto o Ministério da Saúde com a Agência Nacional de Vigilância Sanitária compete à avaliação toxicológica das substâncias e, ao Ministério do Meio Ambiente (MMA) com o Ibama a avaliação dos aspectos ambientais (TERRA e PELAZ, 2008), ou seja realiza a avaliação do potencial de periculosidade ambiental de todos os agrotóxicos registrados no Brasil (MMA, 2013).

Na escala dos Estados as secretarias de Agricultura atuam com os órgãos ambientais locais, do qual faz parte da gestão em Sergipe, a Superintendência do Ibama, a Secretaria de Estado da Agricultura, com a Empresa Estadual de Desenvolvimento Agropecuário (EMDAGRO), Secretaria de Estado da Saúde e a Agência de Vigilância Sanitária Estadual e a, Administração Estadual de Meio Ambiente (ADEMA). Este é 
o modelo institucional operacional brasileiro da gestão dos agrotóxicos para atender as legislações vigentes.

\section{LEGISLAÇÃO RELACIONADA AOS AGROTÓXICOS NO BRASIL}

A Constituição Federal de 1988, aliada a Lei no 6.938, de 31 de agosto de 1981, que trata da Política Nacional de Meio Ambiente (PNMA) visam o controle do lançamento de poluentes no meio ambiente, além de proibir o descarte em níveis nocivos ou perigosos para os seres humanos e outras formas de vida.

No Brasil, os agrotóxicos tem uma cobertura legal ampla, pelo expressivo número de normas legais. Destas, a referência significativa é a Lei no 7.802, de 11 de julho de 1989, que trata do processo de registro de um produto agrotóxico, regulamentada pelo Decreto no 98.816, de 11 de janeiro de 1990.

A Lei no 7.802 de 1989, foi alterada pela Lei no 9.974, de 06 de junho de 2000, dispondo sobre a pesquisa, a experimentação, a produção, a embalagem e rotulagem, o transporte, o armazenamento, a comercialização, a propaganda comercial, a utilização, a importação, a exportação, o destino final dos resíduos e embalagens, o registro, a classificação, o controle, a inspeção e a fiscalização de agrotóxicos, seus componentes e afins.

Porém, o Decreto no 98.816, de 11 de janeiro de 1990, que regulamentou a Lei no 7.802, de 11 de julho de 1989, era mais rigoroso na aplicação de agrotóxicos no meio ambiente, foi substituído pelo Decreto no 4.074, de 04 de janeiro de 2000, regulando de forma objetiva, os agrotóxicos. Em seu Art. 10, diz que é de competência Estadual legislar e fiscalizar o uso dos agrotóxicos e, no Art. 11, supletivamente, os municípios.

Ainda no Art 13, determina a venda de agrotóxicos aos usuários através de receita, por agrônomo habilitado, conforme recomendações da bula. Atribui responsabilidade por danos causados à saúde humana e ao meio ambiente pelo uso em desacordo seja do receituário, seja de recomendação do fabricante ou de órgão sanitário - agrotóxico pelo mesmo agrônomo que prescreveu o uso. Esta ausência tem oportunizado as falhas no mau uso do produto.

Segundo o Ministério do Meio Ambiente (MMA, 2013), essa lei no artigo 3oㅡ, parágrafo 6ํㅜ, proíbe no Brasil, o registro de agrotóxicos nos seguintes casos:

a) Para os quais o Brasil não disponha de métodos para desativação de seus componentes, de modo a impedir que os seus resíduos remanescentes provoquem riscos ao meio ambiente e à saúde pública;

b) para os quais não haja antídoto ou tratamento eficaz no Brasil;

c) que revelem características teratogênicas, carcinogênicas ou mutagênicas, de acordo com os resultados atualizados de experiências da comunidade científica;

d) que provoquem distúrbios hormonais, danos ao aparelho reprodutor, de acordo com procedimentos e experiências atualizadas na comunidade científica;

e) que se revelem mais perigosos para o homem do que os testes de laboratório, com animais, tenham podido demonstrar, segundo critérios técnicos e científicos atualizados; f) cujas características causem danos ao meio ambiente (MMA, 2013)".

Ainda sobre legislação de âmbito Federal, o Decreto Legislativo no 204, de 07 de maio de 2004, ratificou o texto da Convenção de Estocolmo sobre os Poluentes Orgânicos Persistentes (POPs). Acresce-se a Lei no 9.433, de 08 de janeiro de 1997, instituiu a Política Nacional dos Recursos Hídricos, que institui a bacia hidrográfica como unidade de planejamento. Esta lei das águas nos indica que o desenvolvimento sustentável fundamenta- se em princípios da função ecológica da propriedade, da prevenção, da precaução, do poluidor-pagador, do usuário-pagador e da integração, bem como no reconhecimento de valor intrínseco a natureza (CHRISTOFIDIS, 2006).

No caso de delitos ambientais por práticas que envolvam os agrotóxicos, tais condutas são observadas principalmente à luz da Lei no 9.605, de 1998, conhecida como Lei de Crimes Ambientais, e complementada inclusive com o Decreto no 4074 de 2002, acima

Uma regulação criteriosa a ser mencionada são as normas estabelecidas pelo Conselho Nacional de Meio Ambiente (Conama), das quais cita-se a Resolução no 334, de 3 de abril de 2003, dispõe sobre o licenciamento ambiental de estabelecimentos destinados ao recebimento de embalagens vazias de 
agrotóxicos. Trata de recolher as embalagens vazias de agrotóxicos e afins, em conformidade com as legislações mencionadas anteriormente e atende ao que a Política nacional de Resíduos Sólidos, Lei no 12.305 de 2010 disciplina dentre os resíduos perigosos implementar a logística reversa.

Ainda, a Resolução no 357, de 17 de março de 2005, define a classificação dos corpos de água e diretrizes ambientais para o seu Enquadramento, bem como estabelece as condições e padrões de lançamento de efluentes e; b) Resolução CONAMA no 430, de 13 de maio de 2011, que dispõe sobre as condições e padrões de lançamento de efluentes, complementada e alterada na Resolução no 357, de 17 de março de 2005.

Mas com a Portaria Normativa no 84, de 15 de outubro de 1996, que confere ao IBAMA o registro e avaliação do potencial de periculosidade ambiental (PPA) de agrotóxicos, trata de procedimentos de: a) classificação do potencial de periculosidade ambiental; b) estudo de conformidade; c) avaliação do risco ambiental; d0 divulgação de informações; e) monitoramento ambiental; f) fiscalização ( Art. $2^{\circ}$ ).

A classificação dos agrotóxicos quanto ao potencial de periculosidade ambiental segundo esta Portaria, refere-se aos parâmetros bioacumulação, persistência, transporte, toxidade a diversos organismos, potencial mutagênico, teratogênico, carcinogênico, conforme: i) Classe I - Produto Altamente Perigoso; ii) Classe II - Produto Muito Perigoso; iii) Produto Perigoso; iv) Produto Pouco perigoso (Art. $3^{\circ}$ ).

Ainda, define-se no Parágrafo Único, deste artigo, que caso o agrotóxico se enquadre em uma das classes o produto é classificado de "Periculosidade Impeditiva à Obtenção de Registro". E disciplina parâmetros de análise de solos segundo suas classes.

A Avaliação de Risco Ambiental segue a classificação de periculosidade ambiental com base no uso proposto, de acordo com o estabelecido no Anexo VI e da situação de cada caso. Sua divulgação visa promover a Educação Ambiental no estímulo do uso seguro e eficaz para reduzir os impactos negativos no meio ambiente e de prevenir acidentes pelo uso inadequado. Ressalta-se que risco ambiental configura-se segundo Valle e Lage (2008) no dano que um impacto pode causar sobre o meio ambiente.

Todavia, a Lei Federal no 10.831, de 23 de dezembro de 2003, consagra a agricultura orgânica no Brasil e institucionaliza a gestão ambiental sustentável no meio rural, ao promover um sistema de produção orgânico, no qual as práticas agrícolas resultam do uso saudável do solo, da água e do ar, além de reduzir ao mínimo todas as formas de contaminação desses elementos e, mais, reciclar os resíduos orgânicos, reduzindo ao mínimo o emprego de recursos não renováveis, dentre outras finalidades da proteção ao meio ambiente (Art 1으, § 1으, IV e VI).

A legislação diz que o conceito de sistema orgânico de produção agropecuária e industrial considera também o ecológico, biodinâmico, natural, regenerativo, biológico, agroecológicos, permacultura e outros compatíveis aos princípios definidos na mesma (Art. $1^{\mathbf{o}}, \S 2^{\circ}$ ). Portanto está no papel a alternativa sustentável propriamente saudável do sistema de produção agrícola alimentar no país, resta sensibilizar, principalmente, o setor agrícola sua implementação.

\section{CARACTERIZAÇÃO DA ÁREA DE ESTUDO}

\subsection{PERÍMETRO IRRIGADO JACARECICA I}

O projeto público estadual de irrigação do Jacarecica I (Figura 1), planejado em 1983, compreende um área total do perímetro com 398 hectares (ha), segundo a COHIDRO (2013), a viabilidade social e econômica concluído em 1984, mas entrou em operação, somente em março de 1987, com uma área líquida irrigável de 252 ha. Trata-se de uma intervenção fundiária para irrigação por aspersão, onde desapropriaram-se 70 propriedades. Constituiu-se o perímetro em 130 lotes de 2,0 hectares cada unidade, totalizando uma área de aproximadamente 282 ha, correspondente à área adquirida em 1985, pela COHIDRO, órgão responsável pelo projeto. A quantidade de assentados é de 124 famílias, ou 124 unidades produtivas que corresponde a uma área de 248 hectares. Ressalta-se que a área líquida irrigável do perímetro foi reduzida para 252 hectares, pois há dois lotes destinados à pesquisa agrícola. 
Figura 1: Perímetro Irrigado Jacarecica I.

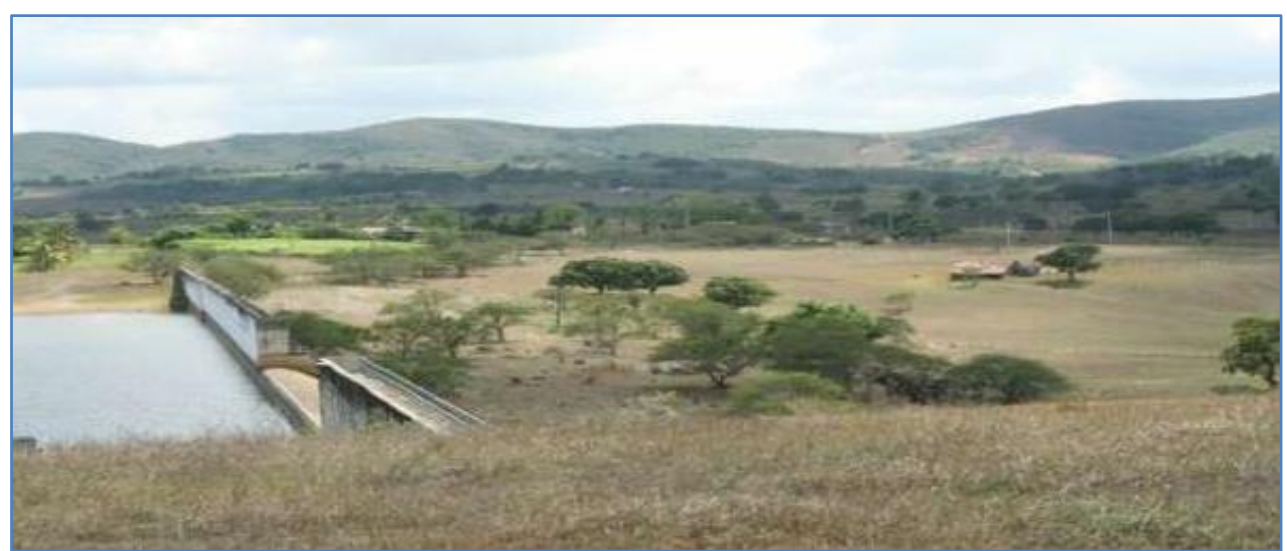

Fonte: Cohidro, 2013.

Os pequenos agricultores assentados em áreas para colonos, que recebem apoio técnico agronômico oriundo de parceria da Embrapa e EMDAGRO e os serviços de operação e manutenção são prestados pela COHIDRO, empresas públicas vinculadas a Secretaria de Estado da Agricultura e do Desenvolvimento Agrário. Além dos serviços creditícios de agências de financiamento financeiro como o Banco do Brasil, o Banco do Nordeste do Brasil e, o Banco do Estado de Sergipe. A área da gravidade, possuindo altura máxima de $20 \mathrm{~m}$ e comprimento de $420 \mathrm{~m}$.

A área de inundação atinge 155,4 ha, com volume de acumulação em torno de $4.700 .000 \mathrm{~m} 3$ de água. 0 projeto localiza-se no município de ltabaiana, Território do Agreste Central, cujas terras margeiam o rio Jacarecica, a oeste da serra de ltabaiana e, a leste encontra-se o meio urbano municipal. Está totalmente contido na bacia do rio Jacarecica, afluente pela margem direita do rio Sergipe. Até a seção do rio onde se localiza a barragem, a área de drenagem é de $221 \mathrm{~km} 2$, Suas principais culturas agrícolas são: batatadoce, alface, milho-doce, quiabo, coentro, pepino, maxixe, pimentão e amendoim, com uma produção total de 5.714 toneladas de alimentos em 2008 (COHIDRO, 2013).

\subsection{PERÍMETRO IRRIGADO JACARECICA II}

A implantação do projeto de irrigação Jacarecica II (figura 2) ocorreu com a desapropriação de uma área com 1998 hectares (ha), conforme a COHIDRO (2013), inicialmente dividida em 76 lotes destinados aos pequenos agricultores e 17 lotes aos empresários agrícolas voltados à exploração de fruteiras, hortaliças e pecuária de leite. Esta área está hoje dividida em 12 lotes empresariais, 03 lotes cedidos em comodato a Associações de Produtores e Trabalhadores Rurais que foram assentados sob a responsabilidade do Movimento Sem Terra (MST) e da Federação dos Trabalhadores da Agricultura de Sergipe (FETASE).

Abrange uma área Total de 1998 ha, dos quais 820 há destina-se a área agrícola irrigável com o método de irrigação por aspersão convencional e microaspersão, distribuídos em 609 famílias assentadas sob a responsabilidade do MST e FETASE, gerando 820 empregos diretos e 1600 indiretos. Recebem assistência técnica, agronômica e os serviços de operação e manutenção são de responsabilidade da Companhia de Desenvolvimento de Recursos Hídricos e Irrigação de Sergipe (COHIDRO), vinculada à Secretaria de Estado da Agricultura e Desenvolvimento Agrário. Enquanto a assistência financeira vem do Banco do Brasil, Banco do Nordeste do Brasil e Banco do Estado de Sergipe.

Posicionado às margens do rio Jacarecica, abrange os municípios de Malhador, Areia Branca e Riachuelo, e dos territórios Agreste Central e Grande Aracaju. A área do perímetro está totalmente contida na bacia do rio Jacarecica. A barragem tem capacidade de acumulação de $30.4000 .00 \mathrm{~m} 3$. Os tipos de solo são Aluviais e Pintossolos e a produção de cultivos agrícolas explorados são: batata-doce, mandioca, macaxeira, inhame, milho, pimentão, repolho, tomate, mamão, maracujá, banana e coco, com uma produção de 68.080 toneladas ao ano. 
Figura 2: Barragem do Jacarecica II.

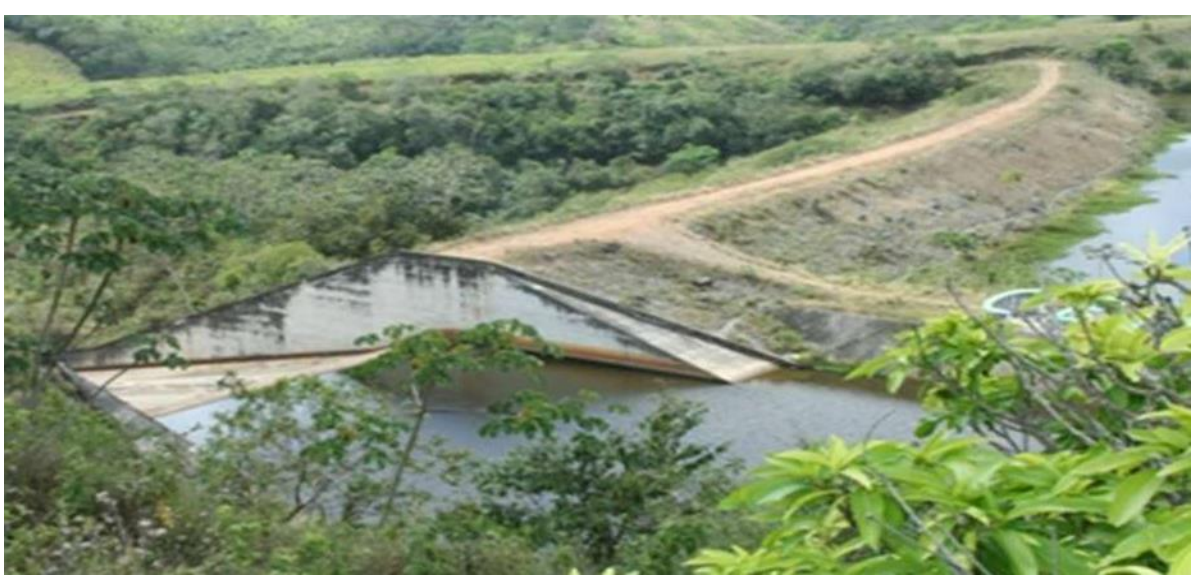

Fonte: COHIDRO, 2013.

O sistema de abastecimento de água da DESO para o consumo humano atende aos municípios de Areia Branca, na área urbana, rio das Pedras, Itabaiana, em parte da sede municipal, além dos povoados Queimadas, Terra Dura, e Sitio Porto, de aumento no consumo, cuja previsão é de uma população aproximada de 105.600 habitantes (COHIDRO, 2013).

\section{IMPACTOS NA SUB-BACIA HIDROGRÁFICA DO RIO JACARECICA EM SERGIIPE}

A sub-bacia hidrográfica do rio Jacarecica é produtora olerícola, principalmente após a instalação de infraestrutura pública estadual de irrigação e a construção da barragem Jacarecica I, no município de Itabaiana, para oportunizar a economia agrícola com a exploração de olericultura durante todo o ano. Lima (2007) diz que este processo transformador da globalização no campo dá-se com o uso de agrotóxicos. Todavia, estas tecnologias oriundas de políticas públicas para otimizar os recursos hídricos potenciais ali presentes, as mesmas foram implantadas de forma centralizada, autoritária e deficitária (PINTO, 1999).

O território de Sergipe apresenta uma geomorfologia modesta e condições climáticas sazonais que vai de um clima litorâneo úmido e um clima semiárido no

Para melhor caracterizar as potencialidades de um sistema ambiental convém identificar as interações dos elementos físicos e suas categorias geográficas como; clima, solo, relevo, rochas e vegetação que sustentam à biodiversidade (fauna e flora), inclusive os humanos que convivem integrados na relação sociedade natureza. Todavia, cabe dizer que o objeto do artigo não é exatamente este, mas cabe igualmente dizer que há na sub-bacia do Jacarecica uma significativa interrelação do homem no uso dos recursos (água e solo) na produção de alimentos para abastecimento humano.

Dentre os elementos físicos dá-se ênfase ao clima e ao solo, fatores inerentes na produção alimentar, dos quais segundo Losano \& Correia (2009) o clima é um elemento condicionador na dinâmica do meio ambiente, contribuindo não apenas na formação dos solos, mas nos recursos hídricos, com repercussão na economia, principalmente na agricultura.

Em Sergipe o clima caracteriza-se por:

"controles físicos comuns dos climas tropicais que incluem as correntes oceânicas ao longo de seu litoral, os efeitos topográficos, minimizados pela topografia local quase insignificante e a continentalidade, bem definida no padrão regional do sertão, agreste e litoral, com o volume decrescendo com o crescente afastamento da fonte de suprimento de unidade de oceano" (PINTO, 1999, p.24)."

Enquanto o solo depende da ação do clima (temperatura, pluviosidade, umidade) sobre as rochas, segundo Fontes e Carvalho (2002), é areno-argiloso dos tabuleiros planossolo solódico eutrófico, muito desenvolvidos, com horizontes bem caracterizados e pobres em nutrientes, apresenta acidez alta e seu uso para fins agrícolas requer a utilização de fertilizantes. Portanto o solo, através de suas 
características nos indica a porta de entrada do uso dos mesmos na agricultura desenvolvida no Jacarecica.

Sergipe apresenta escassez hídrica principalmente na primavera e verão, o que não difere de Itabaiana, território dos projetos de irrigação do Jacarecica I e Jacarecica II (Figura 3). Porém nos meses de maio, junho e julho, há excedente de chuvas, do qual no mês de maio concentra-se a regularidade das precipitações asseguradas pela Frente Polar Atlântica, responsável pela intensidade das chuvas, e quedas de temperatura estendidas até o mês de agosto. Santos (2013) diz que os dados da EMDAGRO no período de 2001 a 2008 indicam precipitações médias mensais elevadas respetivamente nos meses de maio $(128,48 \mathrm{~mm})$, junho $(107,19 \mathrm{~mm})$ e julho $(119,61)$.

As precipitações anuais em Itabaiana apresentam índices de que vão de $1300 \mathrm{~mm}$ na porção do litoral úmido e constantes, enquanto na faixa do Agreste municipal à 900 e 1200 mm (Figura 4), com menor precipitação na fonte de suprimento de umidade do oceano (SANTOS op cit.. Chuva significa entrada e reposição de estoque de água no solo, enquanto a evapotranspiração constitui a saída de água sob a forma de umidade do solo para a atmosfera. A evaporação constitui-se em elemento chave no comportamento atmosférico, tendo em vista que o balanço hídrico é uma relação entre precipitação e temperatura, através das variáveis, conforme Santos (idem), escassez, excedente, retirada e reposição de água.

Figura 3: Localização de perímetros irrigados e pedologia.

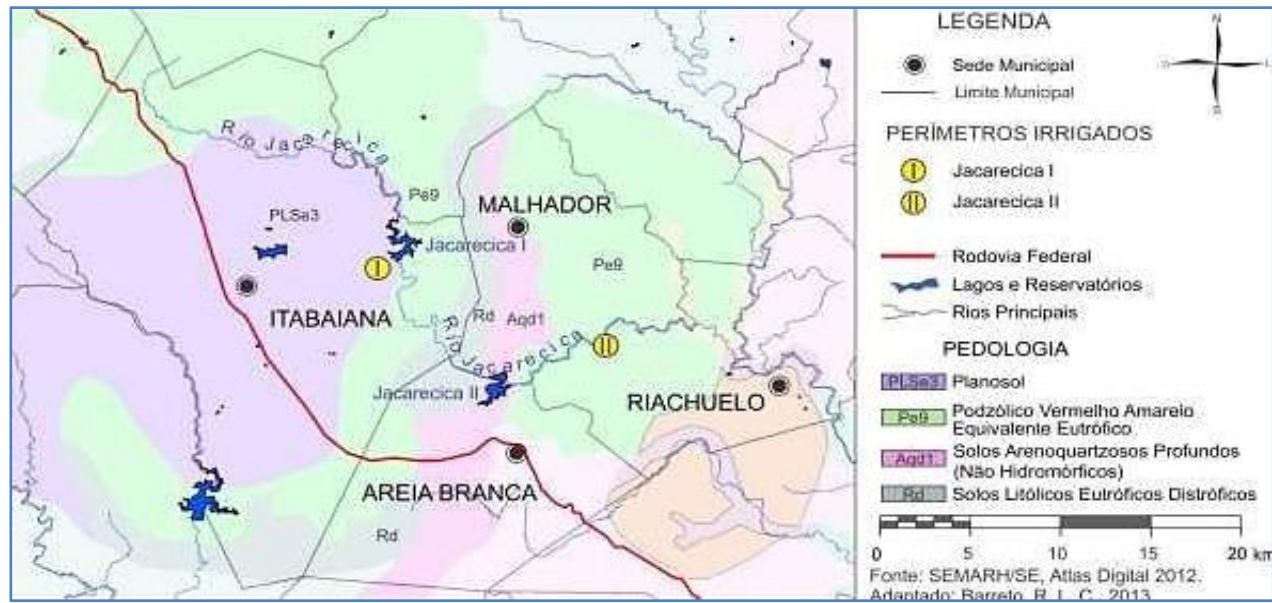

Fonte: Atlas Digital, 2012.

Figura 4: Climatologia do município de Itabaiana, 2010.

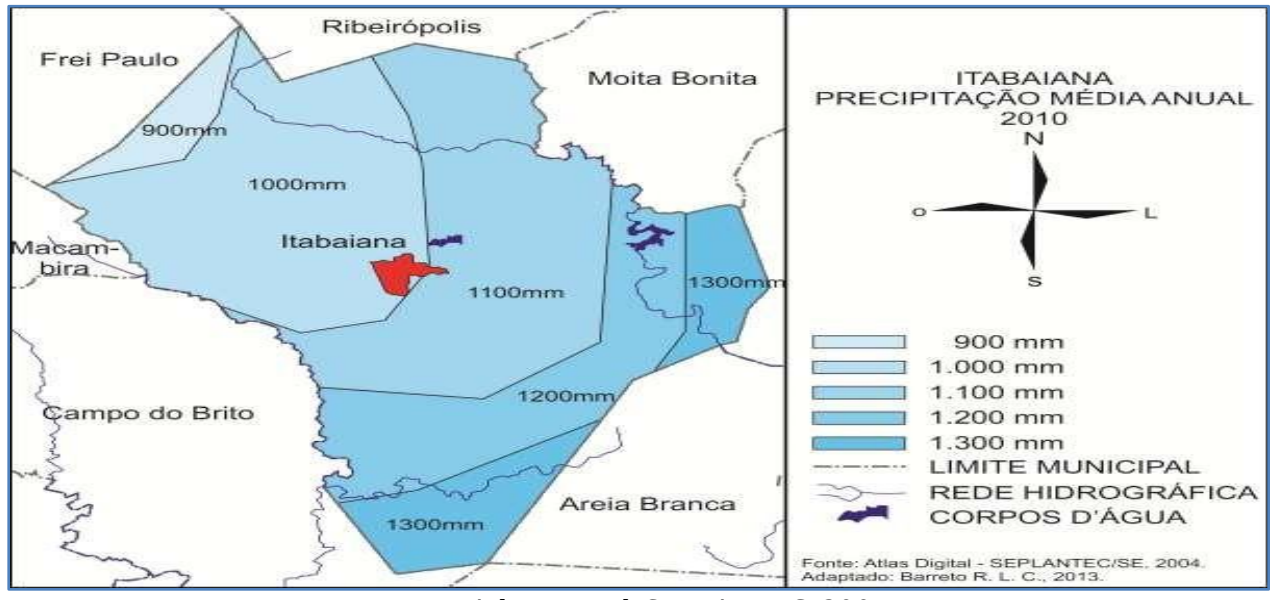

Fonte: Atlas Digital, SEPLANTEC, 2004.

Este sistema de agricultura irrigada tem efeitos ambientais conforme Adissi \& Sobreira (1999) citados em Botelho e Lima (2011), como contaminação do solo, da água e do ar e presença de resíduos nos alimentos, além de agravos à saúde da população, difíceis de detecção à curto prazo apontados em Botelho e Lima (2009). 
Santos e Pinto (2010) comentam que resultado do tipo de estrutura produtiva adotada nos perímetros irrigados ocorre o uso indiscriminado de agrotóxicos, dos quais citam o Dithane, Decis, Tarol e Polytim, sem que os agricultores tomem medidas previstas em lei, quando da aplicação das substâncias. Há uma rejeição no uso dos equipamentos de proteção individual, segundo as autoras, além de não acreditarem que os produtos sejam tóxicos e perigosos, há também os aspectos culturais locais. 0 estudo aponta ainda que segundo a secretaria municipal de saúde de Itabaiana, é significativa a ocorrência de neoplasias e doenças respiratórias entre os agricultores locais (SANTOS e PINTO, 2010, p. 7).

Ainda comentam que nos perímetros irrigados do Jacarecica há o acompanhamento de técnicos da COHIDRO, inclusive realizam a recolha das embalagens das unidades de produção agrícola. 0 que ameniza a situação de risco tanto dos trabalhadores rurais quanto do meio ambiente. Mas Santos e Pinto op. cit., reconhecem que o nível de informação é efêmero, o que requer ações que os sensibilize e os responsabilize pela qualidade ambiental e de suas vidas. Inclusive a produtividade das olerículas nem sempre é acompanhada pela sua alta lucratividade.

Os impactos ambientais elencados no estudo estão apresentados no método de redes de Sorensen, que estabelece relações do tipo causas-condições- efeitos, permitindo melhor identificação dos impactos e suas inter-relações (MAGRINI, 1996, p.98), que foi construído para analisar diversos tipos de uso do solo.

O modelo está adaptado para identificar os impactos ambientais do uso de agrotóxicos nos Projetos de Irrigação na bacia do Jacarecica I e II em Sergipe (Quadro 2).

\section{Quadro 2 - Matriz de Impactos Ambientais no Jacarecica I e II}

\begin{tabular}{|c|c|}
\hline \multicolumn{2}{|r|}{ Matriz de impactos ambientais no Jacarecica I e II em Sergipe } \\
\hline Relação das ações & $\begin{array}{l}\text { Aplicação de agrotóxicos sem controle; } \\
\text { Ausência de equipamentos de proteção individual (EPI); } \\
\text { Manejo inadequado de embalagens de agrotóxicos; } \\
\text { Uso do solo; } \\
\text { Uso dos recursos hídricos; } \\
\text { Cultivos de olericultura e fruticultura irrigada; } \\
\text { Trabalhadores aplicadores de agrotóxicos; } \\
\text { Consumidores de alimentos; } \\
\text { Geração de resíduos de embalagens de agrotóxicos e, } \\
\text { Geração de resíduos domiciliares. }\end{array}$ \\
\hline $\begin{array}{c}\text { Relação de fatores } \\
\text { ambientais }\end{array}$ & $\begin{array}{l}\text { Condições Biológicas: } \\
\text { Flora (árvores, arbustos, cultivos, microflora, plantas aquáticas etc) e, } \\
\text { Fauna (aves, animais terrestres, inclusive répteis, peixes, organismos bentônicos, insetos, microfauna). } \\
\text { Fatores Culturais: } \\
\text { Uso do território (agricultura, residencial) e, } \\
\text { Nível cultural (estilo de vida). }\end{array}$ \\
\hline $\begin{array}{c}\text { Riscos / impacto / } \\
\text { efeito }\end{array}$ & $\begin{array}{l}\text { Poluição química do solo; } \\
\text { Poluição química dos recursos hídricos; } \\
\text { Poluição atmosférica; } \\
\text { Contaminação residual de alimentos; } \\
\text { Contaminação de trabalhadores aplicadores de agrotóxicos; } \\
\text { Contaminação de consumidores de alimentos; } \\
\text { Destinação inadequada de embalagens de agrotóxicos e, } \\
\text { Destinação inadequada de resíduos domiciliares. }\end{array}$ \\
\hline Consequências & $\begin{array}{l}\text { Diminuição da fertilidade do solo, erosão, assoreamento; } \\
\text { Intoxicação de agricultores durante a aplicação de agrotóxicos; } \\
\text { Alteração da qualidade do ar; } \\
\text { Alimentos contaminados com resíduos de agrotóxicos; } \\
\text { Trabalhadores rurais com doenças ocupacionais por agrotóxicos; } \\
\text { Intoxicação da população pelo consumo de alimentos com resíduos de agrotóxicos; } \\
\text { Doenças respiratórias, de pele, de olhos, sistema, nervoso, cardiovascular, neoplasias; } \\
\text { Intoxicação e Morte da fauna e, } \\
\text { Morte da flora e extinção de espécies. }\end{array}$ \\
\hline Mitigação & $\begin{array}{l}\text { Cumprimento da legislação; } \\
\text { Implementar o uso seguro de trabalhadores com agrotóxicos; } \\
\text { Implantação da vigilância à saúde dos trabalhadores e população exposta; } \\
\text { Implantar um comitê de monitoramento do uso de agrotóxico; } \\
\text { Adoção de Equipamento de Proteção Individual (EPI), segundo Norma Regulamentadora do Ministério } \\
\text { do Trabalho (MTE); } \\
\text { Implementar a Lei no } 10.831 \text { / 2003, que dispõe sobre a agricultura orgânica e, } \\
\text { Adoção do controle integrado de pragas substituindo o adubo químico pela adubação orgânica. }\end{array}$ \\
\hline
\end{tabular}




\section{CONCLUSÕES}

O desenvolvimento da agricultura nos perímetros irrigados Jacarecica I e igualmente no Jacarecica II, através do uso de tecnologias postas pelo mercado contribuiu para o avanço crescente da oferta de produtos agrícolas produzidos na bacia hidrográfica do rio Jacarecica. A olericultura e a fruticultura irrigada segundo os autores pesquisados organizam-se pela agricultura familiar e suas culturas, conhecimentos do senso comum e tradições. E embora haja um esforço dos órgãos públicos no apoio técnico e operacional para as melhores práticas, inclusive no uso de agrotóxicos nos cultivos agrícolas.

A fragilidade do solo observada em estudos anteriores é porta de entrada para o uso de fertilizantes objetivando o melhoramento e a produtividade dos cultivos agrícolas, todavia não necessariamente com o uso de agrotóxicos.

Diz-se que até os dias de hoje, há ausência ou insuficiência de técnicas estabelecidas em marcos regulatórios que definem como, onde, quem pode manuseá-lo adequadamente, visando à proteção do usuário desde a aquisição comercial do agrotóxico, quanto à preservação e manutenção quando do manuseio de produtos perigosos que indevidamente afetam agricultores, os cultivos agrícolas, o solo, o ar, os recursos hídricos, a fauna e a flora, esta é a cadeia da poluição que se dá atingindo tanto os humanos, quanto afeta o ambiente como um todo que é transformado em corpo receptor de cargas poluentes químicas.

As embalagens de agrotóxicos não podem ter reutilização nos domicílios, mas entregues ao setor comercial e produtivo que tem a obrigação legal de recebê-la, implementando, em âmbito local a logística reversa, tal como define a política nacional de resíduos sólidos, em vigor desde 2010, e ao mesmo tendo atendendo os parâmetros da gestão ambiental.

\section{REFERÊNCIAS}

[1] BORGES FILHO, E. L. Impactos ambientais ocasionados pelo uso de defensivos agrícolas: a escassez de pesquisas no Programa Nacional de Pesquisa Agropecuária Brasileiro. Campinas/SP: UNICAMP, sd, 20p. Disponível em: www.sober.org.br/palestra/12/080389.pdf; acesso em 30/03/2013; às $15 \mathrm{~h} 50$.

[2] BOTELHO, L.C. e LIMA, I. de S. A utilização de agrotóxicos e a (IN) segurança alimentar. 2011, 17p. Disponível em: http://www.alasru.org/wp-content/uploads/2011/09/GT28-Lauande- Botelho.pdf; acesso em $01 / 04 / 2013$.

[3] BOZIKI et. al. Situação atual da utilização de agrotóxicos e destinação de embalagens na área de proteção ambiental estadual Rota do sol, Rio Grande do Sul, Brasil. São Francisco de Paula: Revista VITAS. № 1, setembro de 2011, 15p. Disponível em:

[4] CHIUVITE, T. B. S. Direito ambiental: para aprender direito. São Paulo: Barros, Fischer \& Associados, 2010, $272 \mathrm{p}$.

[5] CHRISTOFIDIS, M. 0 enquadramento participativo de corpos d'água como um instrumento da gestão de recursos com aplicação na bacia do rio Cubatão Sul-SC. Florianópolis: UFSC. 2006. 176p. (Dissertação de Mestrado). Disponível em: http://www.academia.edu/2644045/Curso_Internacional_em_Gestao_Estrategica_para_o_Des envolvimento_Regional_-_MI; acesso em 01/06/2013; às 12h.

[6] COHIDRO, 2013. Jacarecica I. Disponível em:

http://www.cohidro.se.gov.br/modules/tinyd0/index.php?id=22; acesso em 01/06/2013/ às 20 h57.

[7] COHIDRO, 2013. Jacarecica II. Disponível em: Disponível em:

http://www.cohidro.se.gov.br/modules/tinyd0/index.php?id=45; acesso em 0106/2013; às 21h13.

[8] CONSELHO NACIONAL DO MEIO AMBIENTE (CONAMA). Resolução no 357, de 17 de março de 2005, Dispõe sobre a classificação dos corpos de água e diretrizes ambientais para o seu enquadramento, bem como estabelece as condições e padrões de lançamento de efluentes, e dá outras providências. Brasília/DF: MMA/CONAMA. 2005.

[9] INSTITUTO BRASILEIRO DO MEIO AMBIENTE E DOS RECURSOS NATURAIS RENOVÁVEIS. Manual para requerimento de avaliação ambiental: agrotóxicos e afins.Brasília: IBAMA/DIQUA/CGASQ. 2009. 180p.

[10] FARIA, M. V. de C. Avaliação de ambientes e produtos contaminados por agrotóxicos. In: Peres, Frederico; Moreira, Josino Costa. É veneno ou é remédio: agrotóxicos, saúde e ambiente. Rio de Janeiro,

[11] FIOCRUZ, 2003. p.177-209. Disponível em: http://bases.bireme.br/cgibin/wxislind.exe/iah/online/?IsisScript=iah/iah.xis\&src=google\&base=LILACS\&lang=p\&next Action=lnk\&exprSearch=352760\&indexSearch=ID; acesso em 02/05/2013. 
[12] FONTES, A. L. \& CORREIA, A. L. F. Agricultura e meio ambiente na sub-bacia do rio Jacarecica (SE) 2009,12 p. Disponível em: http://egal2009.easyplanners.info/area06/6339_Fontes_Aracy_Losano_Fontes.pdf; acesso em

[13] JUNK, W. J. Capacidade de suporte de ecossistemas: Amazônia como estudo de caso. In: TAUKTORNISIELO et al (Orgs.).Análise ambiental: estratégias e ações. São Paulo: UNESP, 1995. 381p.

[14] LIMA, A. de S. Globalização: influências das técnicas e tecnologias na organização do espaço e meio ambiente. In: Ateliê Geográfico, revista eletrônica. Goiânia-GO: UFG/IESA. v. 1. n. 2, 2007. p.42-58. Disponível em: www.revistas.ufg.br/index.php/atelie/article/download/3010/305 ; acesso 15/06/2013.

[15] LUCENA, R. B. de, e SOUZA, N. de J. de. Políticas agrícolas e desempenho da agricultura brasileira: 1950-00. In: Indicadores Econômicos. Revista FEE, Porto Alegre, v. 29. N. 2, p. 180- 200, 2001. Disponível em: http://revistas.fee.tche.br/index.php/indicadores/article/view/1313; acesso em 01/04/2013.

[16] MARASCHIN, L. Avaliação do grau de contaminação por pesticidas na água dos principais rios formadores do Pantanal Mato-Grossense. Cuiabá/Mato Grosso: UFMT. 2003, 90p. Disponível em: www.cpap.embrapa.br/teses/online/DST23.pdf; acesso em 30/03/2013; às 11h41.

[17] MARGULIS, S. Meio Ambiente: aspectos técnicos e econômicos. 2. Ed. Brasília: IPEA, 1996, 246p.

[18] MARQUES, M.N. Avaliação do impacto de agrotóxicos em áreas de proteção ambiental, pertencentes à bacia hidrográfica do rio Ribeira de Iguape, São Paulo. Uma contribuição à análise crítica da legislação sobre o padrão de potabilidade. São Paulo: Instituto de Pesquisas Energéticas e Nucleares/USP. 2005, 218p. (Tese de Doutorado). Disponível em: Disponível em: www.pelicano.ipen.br/PosG230/texto completo/Maria Nogueira Marques. Pdf; acesso em 01/04/13/às 23h09.

[19] MINISTÉRIO DO MEIO AMBIENTE. Convenção de Roterdã: sobre o procedimento de consentimento prévio informado aplicado a certos agrotóxicos e substâncias químicas perigosas objeto de comércio internacional. Brasília: MMA. 2009, 42p.

[20] MINISTÉRIO DO MEIO AMBIENTE. Segurança química e agrotóxicos. Brasília: MMA. 2013. Disponível em: http://www.mma.gov.br/seguranca-quimica/agrotoxicos; acesso em 20/03/2013; às 16h56.

[21] PASSOS, E. A. Instrumento de gestão de recursos hídricos: enquadramento dos corpos d' água. Módulo VI. São Cristóvão: UFS/LQA. 2012. (Resumos de aula em slide).

[22] PELAZ. V. et. al. A regulamentação dos agrotóxicos no Brasil: entre o poder de mercado e a defesa da saúde e do meio ambiente. In: Revista de Economia-SER. PR: Edt. UFPR/Pró-Reitoria

[23] http://ojs.c3sl.ufpr.br/ojs2/index.php/economia/article/viewArticle/20523; aceso em 01/04/2013.

[24] PINTO, J. E. S. de S. Os reflexos da seca no Estado de Sergipe. São Cristóvão: NPGEO/UFS. 1999. (Tese de Doutorado).

[25] RIBEIRO, A. F. A., BRITO R. F., FRANCA, R. R., \& Carvalho, M. E. S. et al Estudo ambiental do rio Jacarecica no povoado Candeias, Moita Bonita - SE, 2012, p.933-945. Disponível em: www.Revistageonorte.ufam.edu.br/...nts/009_ESTUDO...; acesso em 20/05/2013.

[26] SÁNCHEZ, Luis Enrique. Avaliação de Impacto Ambiental: conceitos e métodos. São Paulo: Oficina de textos, 2008, 495p.

[27] SANTOS, C. dos O. Questões socioambientais nos perímetros irrigados do município de Itabaiana/SE. In: ACTA Geográfica, Boa Vista, v.7, n.14, jan./abr. de 2013. pp.139-152.

[28] Disponível em: revista.ufrr.br/index.php/actageo/article/download/754/1001; acesso em 20/05/2013.

[29] SANTOS, C.O. \& PINTO, J. E. S. de S. Questões socioambientais nos perímetros irrigados do município de Itabaiana/SE. Porto Alegre: XVI ENG. 2010, p1-11. Disponível em: http://www.google.com.br/search?newwindow=1\&site=\&source=hp\&q=Quest\%C3\%B5es+soci oambientais+nos+per\%C3\%ADmetros+irrigados+do+munic\%C3\%ADpio+de+Itabaiana\%2FSE.+P orto\&oq=Quest $\% \mathrm{C} 3 \%$ B5es+socioambientais+nos+per\%C3\%ADmetros+irrigados+do+munic\%C3\%ADpio+de+Itaba iana\%2FSE.+Porto\&gs_l=hp.12...0.0.1.18154.0.0.0.0.0.0.0.0..0.0...0...1c..25.hp..1.0.0.Kq4DzZB3Wxk; acesso em 20/05/2013.

[30] SOUZA, J. E. de et al. Recursos hídricos e gestão ambiental nos perímetros irrigados Ribeira e Jacarecica I, entre os municípios de Itabaiana e Campo do Brito, SE. In: XI jornada do Trabalho: Trabalho e as Escalas da Práxis Emancipatórias: autonomia de classe frente à territorialização do capital. João Pessoa: UFPB 2010, 15p. Disponível em: $\quad$ http://www4.fct.unesp.br/ceget/ANAISXIJORNADA/Artigos\%20GT1\%20PDF/GT105\%20Eliene\%20Domingas\%20de\%20Souza,\%20Josefa\%20Edilani\%20de\%20Souza,\%20An dre\%20Maria\%20dos\%20Santos,\%20Luciano\%20Andrade.pdf; acesso 01/06/2013.

[31] SPADOTTO, C. A. Abordagem Interdisciplinar na avaliação ambiental de agrotóxicos. In: Revista Núcleo de Pesquisa Interdisciplinar, São Manuel, SP. p.1-9, 2006. Disponível em: http://www.fmr.edu.br/npi/003.pdf; acesso em 02/05/2013. 
[32] SPADOTTO, C. A. et al. Monitoramento do risco ambiental de agrotóxicos: princípios e recomendações.

[33] Jaguariúna, SP. 2004, 29p. Disponível em: http://www.cnpma.embrapa.br/download/documentos_42.pdf; acesso em 01/04/2013.

[34] TERRA, F. H. B. e PELAZ, V. A história da indústria de agrotóxicos no Brasil: das primeiras fábricas na década de 1940 aos anos 2000. Curitiba: IE/UFU e PPGE/UFRGS, Uberlândia - MG e PPGDE/DE/UFPR, Curitiba-PR. 2008, 21p.

[35] VALLE, C. E do \& LAGE, H. Meio Ambiente: acidentes, lições, soluções. São Paulo: Editora Senac São Paulo, 2003, 256p. 


\title{
CAPÍTULO 09 Estimativa de produtividade da cultura do sorgo a partir do metodo da zona agroecologica (ZAE) no perimetro irrigado Jacarecica I
}

\author{
Lucas de Oliveira Cunha \\ Gregorio Guirado Faccioli
}

\section{INTRODUÇÃO}

O Brasil é um dos maiores exportadores de produtos agrícolas do mundo e segundo a FAO até 2019 será o maior produtor agrícola do globo. Fatores como clima, solo e água levam a esse potencial exuberante.

Apesar de possuir variáveis que tornam o Brasil um grande produtor agrícola existem outros fatores que devem ser levados em consideração como a estrutura fundiária, que perpassa pelo modelo de colonização sofrido e o torna o campeão mundial em concentração de terras, o uso indiscriminado de agrotóxicos, consumindo quase vinte por cento de todo o veneno produzido no mundo. Apesar de ainda não ser o maior produtor mundial de produtos agrícolas já é pelo terceiro ano o maior consumidor dos chamados "defensivos". Fatores como estes são desafios que devem ser encarados para que a agricultura brasileira tenha crescimento e sustentabilidade.

No caso especifico do nordeste brasileiro, é uma região que tem bioma e dinâmica próprios. Tendo áreas castigadas não somente pelos baixos índices pluviométricos, mas muito mais pela irregularidade da distribuição das chuvas que historicamente causam quebras de safras nos municípios eminentemente agrícolas do semiárido nordestino. Os vários perímetros irrigados na região nordestes contribuem para diminuir os impactos sociais e econômicos destas adversidades climáticas.

No estado de Sergipe, hoje, existem 8 perímetros irrigados que apresentam grande potencial produtivo para refletirem positivamente no senário social e econômico local e regional, porém os mesmos também possuem falhas, sejam elas na sua concepção, gestão ou estratégia. Estes perímetros possuem condições agronômicas e econômicas de produção de uma grande variedade de produtos agrícolas, dentre eles os grãos e forragens, incluindo assim a cultura do sorgo.

0 sorgo tem origem africana e é o quinto cereal mais importante do planeta, antecedido pelo trigo, arroz milho e cevada. Dentre as suas finalidades estão a produção de farinha para panificação, amido industrial, álcool e para alimentação animal tem a destinação de ração através do grão e podem ter a finalidade de forragem a depender da variedade.

Para contribuir com as grandes possibilidades de produção dos perímetros irrigados e suas viabilidades econômicas é que existem modelagens de sistemas agrícolas, que são equações matemáticas que regam simulações de produção. Essas simulações possibilitam a configuração de vários cenários que levam em conta fatores fisiológicos e climáticos. Isso permite tanto a nível de produtor, perímetro, região ou Estado a utilização mais eficiente da irrigação de acordo com as culturas e variedades propostas.

O presente trabalho teve como objetivo estimar a produtividade da cultura do sorgo nos plantios sequeiro e irrigado no perímetro Jacarecica I, município de Itabaiana, Sergipe.

\section{REVISÃO DE LITERATURA}

\section{1- BALANÇO HÍDRICO}

O monitoramento da disponibilidade de água do solo torna-se indispensável para o estabelecimento de estratégias de projeto e manejo que otimizem o uso da água pelas culturas. 0 balanço hídrico destaca-se 
entre os métodos de monitoramento de água no solo e se baseia na quantificação das entradas e saídas de água no sistema solo-planta (CINTRA et al., 2000).

Dentre as variáveis de saída, destaca-se a evapotranspiração da cultura, que por sua vez apresenta declínio em condições de déficit hídrico. Tal redução pode ser numericamente expressa pelo coeficiente de estresse de água (Ks). 0 Ks apresenta várias metodologias de cálculo, que reduzem a evapotranspiração da cultura de forma linear, logarítmica ou somente a partir de determinado ponto da umidade do solo (ALLEN et al., 1998), de forma a se obter a evapotranspiração real da cultura.

Assim, torna-se necessário a avaliação da influência dos métodos de cálculo de Ks na determinação da água no solo e sua comparação com outras metodologias de determinação da água no solo (ROCHA et al., 2012).

0 desenvolvimento e a utilização de modelos voltados às atividades agrícolas têm se intensificado nos últimos anos. A literatura tem mostrado que o desenvolvimento e aprimoramento de modelos de simulação de balanço hídrico têm resultado em interessantes ferramentas para estimar alternativas de planejamento, dimensionamento e manejo da irrigação (SOUZA e GOMES, 2008).

Pereira, Villa Nova e Sediyama (1997) comentam que o monitoramento do armazenamento e das entradas e saídas de água no solo, assim como a definição dos períodos com provável deficiência hídrica, podem ser realizados de forma eficiente aplicando a metodologia proposta por Thornthwaite e Mather (1955). Esta metodologia se baseia na dinâmica do armazenamento de água no solo e ainda pode ser realizada considerando apenas dados climáticos de precipitação e temperatura do ar.

O balanço hídrico climatológico de Thornthwaite e Mather (1955) foi desenvolvido para determinar o regime hídrico de um local, sem a necessidade de medidas diretas das condições do solo. Para sua elaboração, há necessidade de se definir, para uma determinada região ou local a capacidade de água disponível (CAD) no solo, os valores de precipitação (P) e evapotranspiração de referência (ETo) para um período considerado. Com essas informações básicas, a metodologia permite estimar, para o mesmo período, o armazenamento da água no solo (Arm), a evapotranspiração real (ETr), deficiência (Def) e excedente hídrico (Exc) (PEREIRA, VILLA NOVA e SEDIYAMA, 1997).

Angiolella et al., (2005) comenta que a estimativa do balanço hídrico surgiu da necessidade de se contabilizar a chuva e a evapotranspiração que ocorre em um ecossistema, objetivando o conhecimento da disponibilidade de água para as plantas. Visando equacionar esta relação, surgiram diferentes métodos de cálculo, dentre eles, o conhecido balanço hídrico climatológico de Thornthwaite e Mather (1955). Tal modelo baseia-se na estimativa das entradas e saídas de água de um volume de controle, resultante da aplicação do princípio de conservação de massa para um volume de solo vegetado, possibilitando informações sobre ganhos, perdas e armazenamento da água pelo solo.

0 conhecimento de como as plantas utiliza a água do solo e de como respondem aos níveis de armazenagem a partir do balanço hídrico, pode ser uma saída viável para o estabelecimento de estratégias eficazes de manejo visando o melhor uso das reservas de água no solo pelas culturas. 0 movimento cíclico da água na lavoura começa com a sua penetração no solo por meio de infiltração, continua com seu armazenamento temporário na zona do sistema radicular e termina com sua remoção do solo por meio de drenagem, da evaporação e da absorção pelas raízes (HILLEL, 1970).

Para efetuar o balanço hídrico de uma cultura é necessário, portanto, computar as entradas de água no solo via precipitação pluvial ou irrigação, a partir da sua infiltração na superfície, e as saídas, representadas pela drenagem interna, evapotranspiração e deflúvio superficial num volume de solo, com base na configuração do sistema radicular da cultura em estudo, em determinado período de tempo; se a quantidade de água que entre no tempo considerado for maior que a quantidade que sai durante o mesmo período, o saldo será positivo e, caso contrário, será negativo. Tanto o saldo positivo quanto o saldo negativo são medidos pela variação de armazenagem de água no perfil do solo no período considerado (LIBARDI, 1995).

A importância do balanço hídrico como ferramenta para avaliara a intensidade das saídas e entradas de água no solo e, por conseguinte, para definição dos períodos mais prováveis de déficit hídrico para cultura, está relacionada não só aos conhecimentos dos fatores que o compõem (evapotranspiração, precipitação, drenagem interna ou ascensão capilar) como, também, ao conhecimento das características da planta, principalmente sua fenologia, que representa o ponto de partida para interpretação coerente dos resultados do balanço (CINTRA, 2000). 


\section{2- MODELAGEM DE SISTEMAS AGRÍCOLAS}

A modelagem de sistemas agrícolas é importante por oferecer uma forma prática para incorporar os resultados da experimentação agrícola, compactando um amplo conjunto de informações, servindo assim, como um meio de transmissão e padronização de tecnologia. Os modelos podem ser implementados através de programas que possam ser utilizados por agricultores, pesquisadores e agroindústrias. As simulações computacionais permitem avaliar diversas condições de produção agrícola considerando várias condições ambientais possíveis. As simulações da produção, considerando condições ambientais, possibilitam ao produtor, determinar as melhores culturas / variedades e formas de manejo para reduzir os prejuízos devido a condições adversas de cultivo. Além disso, os modelos agrícolas permitem determinar os riscos envolvidos para as culturas em cada região agrícola auxiliando o planejamento de políticas públicas de seguros (GODOY, 2007).

Os modelos de simulação são ferramentas que permitem gerar cenários, considerando as diversas combinações dos fatores que influenciam na produtividade das culturas. Desta forma, é possível avaliar as estratégias mais adequadas em cada condição específica, possibilitando modificar a estratégia de irrigação para predizer as alterações nos componentes de produção e de outras variáveis, como a evapotranspiração e as necessidades de água da cultura. Além disso, é possível combinar os resultados do modelo com os fatores econômicos, para a análise de riscos associados a cada estratégia (JONES e RITCHIE, 1990).

Os modelos de simulação fisiológica da produção agrícola são equações matemáticas que representam as reações que ocorrem dentro da planta e as interações entre a planta e o meio ambiente. Devido à complexidade deste sistema e ao estado incompleto do conhecimento presente, torna-se impossível representar completamente o sistema em termos matemáticos e por isto, modelos agrícolas são imagens relativamente simplificadas da realidade. Ao contrário dos campos da engenharia e da física, modelos universais não existem na modelagem de crescimento vegetal (GODOY, 2007).

Segundo Sousa et al. (1999) a avaliação econômica da irrigação frequentemente envolve a quantificação da produtividade em resposta ao total de água aplicada. A caracterização da resposta da cultura à aplicação de água tem sido amplamente conhecida como função de produção Água-Cultura.

Os modelos estatísticos que melhor se ajustam à relação água-produtividade e que são mais comumente utilizados nas análises econômicas das pesquisas agrícolas são: Quadrático, Raiz Quadrada, MitschelichSpillman e Potência 3/2 (HEXEM; HEADY, 1978).

Entre esses, destaca-se o modelo Quadrático, que, na maioria das vezes, melhor representa a estimativa de produção em estudo de Função de Produção em agricultura irrigada no Brasil.

Doorenbos e Kassam (1979) propuseram um modelo empírico para a quantificação da relação entre a produtividade e a água, sob a forma da expressão:

$$
1-\frac{Y_{r}}{Y_{m}}=K y\left(1-\frac{E T_{r}}{E T_{m}}\right)
$$

em que: Yr - produtividade real; Ym - produtividade máxima;

ETr - evapotranspiração real;

ETm - evapotranspiração máxima.

Ky - fator de sensibilidade da cultura à deficiência de água ou taxa de redução da produtividade.

Andrioli et al. (2006) utilizou o modelo da FAO para a estimativa da produtividade potencial (PP) e real (PR) do milho em Piracicaba - SP, e determinou que o modelo da FAO, tanto para a estimativa de PP como da PR apresentou desempenho satisfatório, com alta exatidão $(b=0,99)$ e boa precisão $\left(R^{2}=0,80\right)$, mostrando, portanto, ser uma ferramenta útil para a previsão de safras do milho. Oliveira et al. (2012) utilizou o mesmo modelo para a simulação de crescimento de outra gramínea, a cana-de-açúcar, na região de Minas Gerais. 
Santos Júnior (2011) utilizou a função produção do milho desenvolvido por Gomes et al.(1990) para a região do perímetro Irrigado Formoso, na Bahia. Em seu projeto, Santos Júnior (2011) avaliou a viabilidade da irrigação da cultura do milho.

\section{MATERIAL E MÉTODOS}

O projeto foi desenvolvido em parceria com a Universidade Federal de Alagoas, Campus Arapiraca.

\section{1- CARACTERIZAÇõES DA ÁREA EXPERIMENTAL}

0 presente trabalho foi realizado a partir de dados do perímetro irrigado Jacarecica I $\left(10^{\circ} 39^{\prime} 220^{\prime \prime} \mathrm{S}\right.$ e $\left.37^{\circ} 21^{\prime} 502^{\prime \prime}\right)$. Esse projeto que teve sua implantação a partir de 1987, com uma intervenção fundiária onde foram desapropriadas 70 imóveis rurais. É constituído por 130 lotes de 2,0 hectares cada um, beneficiando um total de 124 famílias.

o perímetro se encontra no município de Itabaiana, localizado no território do Agreste Central, o clima da cidade é tropical com estação seca, composto de um período de quatro a cinco meses de seca e temperaturas entre $34,5^{\circ} \mathrm{C}$ e $35^{\circ} \mathrm{C}$.

\section{2- DESCRIÇÕES DO MODELO}

A PR (Produtividade do sorgo limitada pela disponibilidade hídrica ao longo do ciclo) obtida pelo método ZAE, é resultante da PP penalizada pelo estresse hídrico e obtida pelo fator (1 - ETr/ETc), em função da sua sensibilidade ao déficit hídrico (Ky), utilizando-se a Eq. a seguir:

\section{EXPRESSÃO ???}

Os valores de Ky serão retirados de Doorenbos \& Kassam (1979).

O método ZAE calcula a produção potencial de biomassa em função da temperatura do ar, da irradiância solar e da duração do ciclo da cultura, além de fatores genético; em seguida, a produtividade potencial é penalizada utilizando-se o coeficiente de sensibilidade da produtividade ao déficit de umidade no solo (Ky). A produtividade potencial da cultura do sorgo representa o nível de referência de produtividade atingível com alto padrão de manejo da cultura e água, em que não há limitações de clima, água e nutrientes e sem ataque de pragas e doenças (DOORENBOS \& KASSAM, 1979).

$$
\mathrm{Ymp}=\mathrm{cL} . \mathrm{cN} . \mathrm{cH} . \mathrm{G}[\mathrm{F}(0 .:,+0.025 \mathrm{ym}) \mathrm{yo}+(1-\mathrm{F})(0.05 \mathrm{ym}) \mathrm{yc}]
$$

Em que:

Ymp - Produtividade potencial máxima da cultura (kg/ha/período); cL - correção em função do desenvolvimento da cultura e área foliar; $\mathrm{cN}$ - correção para a produção de matéria seca;

cH - correção para a parte colhida;

G - período total do crescimento (dia);

F - Fração do dia em que o sol fica encoberto por nuvens;

Ym - Taxa de produção de matéria seca das folhas(kg/ha/período); Yc - taxa de produção bruta de matéria seca ( $\mathrm{kg} / \mathrm{ha} /$ período).

No cálculo da produtividade limitada pela disponibilidade hídrica constata-se que a evapotranspiração máxima da cultura (ETc) é relacionada com a evapotranspiração de referência (ETo) por meio de um coeficiente de cultura (Kc), como apresentado na equação a seguir: 


$$
\mathrm{ETc}=\text { Kc ETo }
$$

A evapotranspiração de referência foi calculada de acordo com a Equação de Penman-Montheith.

Para a estimativa do balanço hídrico sequencial diário adotou-se o procedimento proposto no Manual 56 da F.A.O., em que considera-se o consumo de água real e o máximo.

\section{ETreal $=$ ETo $\times$ Kc $\times$ Ks}

Em que o Ks é o coeficiente de estresse hídrico (adimensional).

$$
\mathrm{Ks}=\operatorname{Ln}(\mathrm{LAA}+1) / \operatorname{Ln}(\mathrm{CRA}+1)
$$

Em que LAA é a lâmina real de água no solo ( $\mathrm{mm}$ ) e CRA é capacidade real de água no solo (mm).

Quando as necessidades hídricas da cultura forem atendidas plenamente, a evapotranspiração real (ETr) será igual à evapotranspiração da cultura (ETc). Todavia, quando o suprimento for insuficiente tem-se que ETr < ETc e a perda de produtividade será proporcional ao estresse hídrico sofrido pela cultura.

0 método ZAE calcula a produção potencial de biomassa em função da temperatura do ar, da irradiância solar e da duração do ciclo da cultura, além de fatores genético; em seguida, a produtividade potencial é penalizada utilizando-se o coeficiente de sensibilidade da produtividade ao déficit de umidade no solo (Ky). A produtividade potencial da cultura do sorgo representa o nível de referência de produtividade atingível com alto padrão de manejo da cultura e água, em que não há limitações de clima, água e nutrientes e sem ataque de pragas e doenças (DOORENBOS \& KASSAM, 1979).

\section{3- SIMULAÇÃO}

Os cenários da simulação foram baseados nas épocas de plantio e na disponibilidade de água para a cultura. Épocas de plantio (3 datas por mês - a cada 10 dias) X Disponibilidade de água (irrigado e sequeiro), totalizando 72 cenários. Foram utilizados 5 anos de simulação.

As simulações foram feitas para o perímetro irrigado Jacarecica I (10³9' 220" S e $\left.37^{\circ} 21^{\prime} 502^{\prime \prime}\right)$. Esse projeto que teve sua implantação a partir de 1987, com uma intervenção fundiária onde foram desapropriadas 70 imóveis rurais. É constituído por 130 lotes de 2,0 hectares cada um, beneficiando um total de 124 famílias.

O perímetro se encontra no município de Itabaiana, localizado no território do Agreste Central, o clima 0 clima da cidade é tropical com estação seca, composto de um período de quatro a cinco meses de seca e temperaturas entre $34,5^{\circ} \mathrm{C}$ e $35^{\circ} \mathrm{C}$.

Os dados meteorológicos foram obtidos de dados da COHIDRO, EMDAGRO E SEMARH. Os anos utilizados foram de 2004 a 2009.

O conjunto das variáveis meteorológicas diárias de entrada utilizados pelo modelo, correspondente aos valores diários de temperatura máxima e mínima do ar $\left({ }^{\circ} \mathrm{C}\right)$, precipitação pluviométrica (mm) e radiação solar (MJ m-2 dia-1). A radiação solar foi estimada pela expressão HARGREAVES e ALLEN (2003) empregando-se a seguinte equação:

$$
\mathrm{RsH}=0,16 .(\mathrm{Tmax}-\mathrm{Tmin}) 0,5 . \mathrm{Ra} \text { em que, }
$$

RsH - radiação solar global estimada pelo método de Hargreaves, MJ m-2 dia-1.

$\mathrm{Ra}$ - radiação no topo da atmosfera dependente do dia Julianno e Latitude, MJ/m2.dia-1 
Procurou-se utilizar os anos de dados com menor número de falhas, ou que não houvesse falhas, sendo que para a correção de falhas simples (intervalo pequeno de dias), utilizou-se a metodologia proposta por Heinemann et al. (2007).

Devido a limitação de variáveis meteorológicas disponíveis, os valores diários da evapotranspiração de referência (ETo) foram calculados a partir do método de Hargreaves que pode ser descrito da seguinte forma (ALLEN et al.,1998; HARGREAVES; ALLEN, 2003):

$$
\text { EToH=0,0009.Ra.(Tmax }- \text { Tmin)0,5.(Tmed + 17,8) (1) }
$$

em que,

EToH - evapotranspiração de referência pelo método de Hargreaves, mm dia-1; Ra - radiação solar incidente no topo da atmosfera, MJ m-2 dia-1;

Tmax - temperatura máxima do ar, oㅡ, Tmin - temperatura mínima do ar, ${ }^{\circ} \mathrm{C}$.

\section{RESULTADO E DISCUSSÃO}

Para a calibração do modelo, foram realizadas alterações nos parâmetros cL, cN e cG, que correspondem à correção do desenvolvimento da cultura em função da área foliar, à correção da produção de matéria seca e à correção do fator de colheita., respectivamente; até que os valores estimados ficassem próximos aos observados.

No gráfico 01 são observados os valores de produtividade observada e estimada do sorgo em AraripinaPE.

Gráfico 01: Dados observados, eixo x, e estimados, eixo y, para a produtividade do sorgo em AraripinaPE.

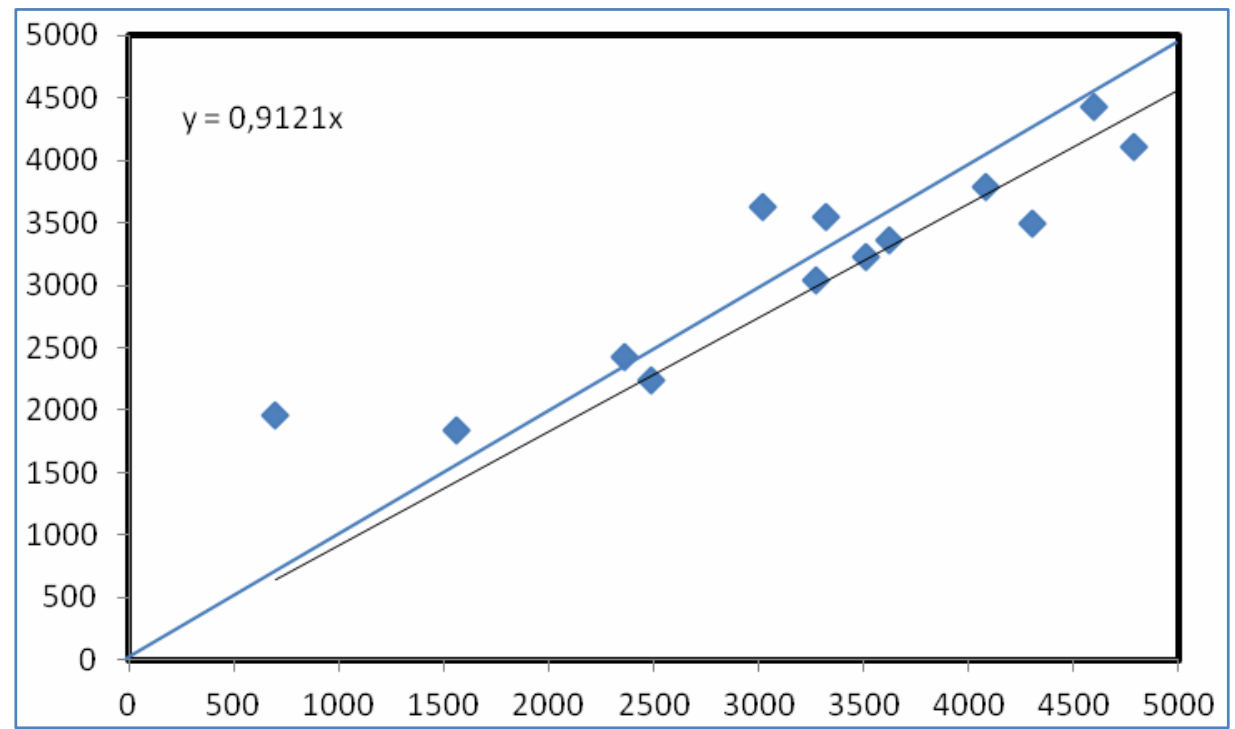

Os dados obtidos demonstrados no gráfico da figura 1 revelar-se que os valores estimados estão subestimados em 8,79\% em relação aos valores observados.

No Gráfico 2, estão as produtividades do sorgo em regime sequeiro e irrigado, para diferentes épocas de plantio. Pode-se notar que a produtividade do sorgo sequeiro plantando entre 31 de março (ponto 10) até 19 de maio (ponto 18) é a que apresenta os maiores valores, estes variando de 3,578 a quase 3,232 Mg.ha- ${ }^{1}$. 0 maior valor atingido foi para 10 de abril, e a partir dessa data inicia-se o declínio da produtividade. 
Gráfico 2: Produtividade do sorgo no perímetro irrigado Jacarecica I, com diferentes épocas de plantio, nos regimes sequeiro e irrigado.

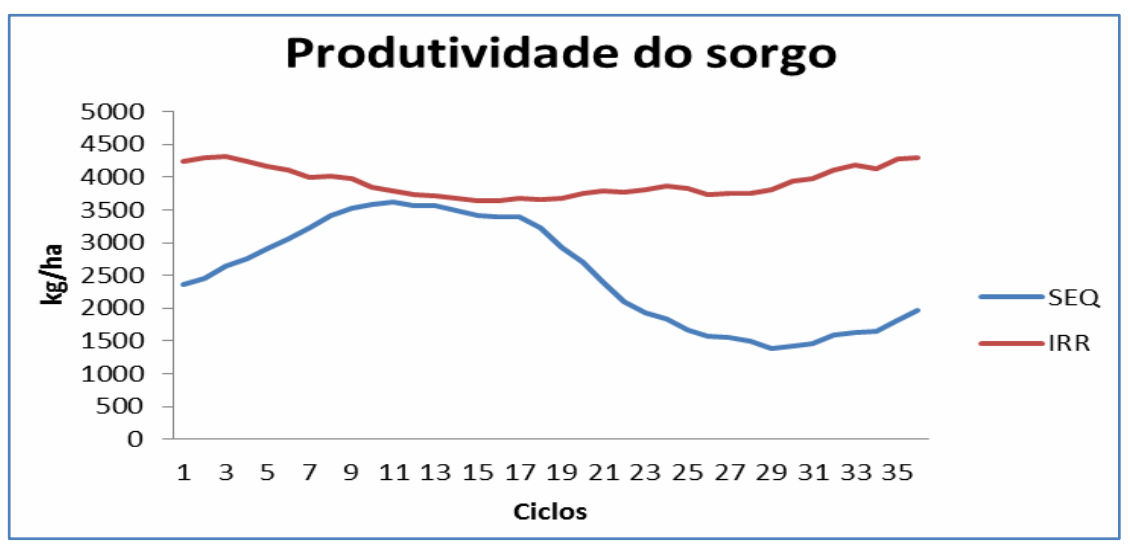

As épocas menos indicadas, baseada na produtividade, para o plantio do sorgo sequeiro compreende 19 de julho a 06 de dezembro. Ainda é possível notar que há grande variabilidade da produtividade do sorgo sequeiro na região, demonstrando que nesta região o balanço hídrico anual é fator limitante da produção.

Dessa forma, através da irrigação é possível o plantio em qualquer época do ano, podendo-se atingir produtividades que variam de acima de 3,5 a aproximadamente 4,5 Mg.ha- ${ }^{1}$. As maiores produtividades foram obtidas nos plantios realizados entre 06 de dezembro a 21 de janeiro.

Comparando os dois sistemas, irrigado e sequeiro, é possível verificar que durante o período de 31 de março a 09 de junho, a produtividade do sorgo sequeiro é equivalente a produtividade do sorgo irrigado, com uma diferença media de $7 \%$.

Apesar dos dados de produtividade informarem qual a melhor época de se atingir as melhores produtividades, o produtor de grão precisa também levar em consideração o fator econômico. Esse fator deve ser levado em consideração na hora do plantio e na hora da adoção ou não de uma nova tecnologia como a irrigação.

\section{CONCLUSÕES}

A calibração realizada apresentou índices estatísticos que permitem a utilização do modelo para a estimativa da produtividade do sorgo.

Para o plantio em sequeiro, as melhores datas de plantio para a cultura do sorgo são de 31 de março a 29 de junho conforme dados do anexo 1 . Neste mesmo período analisando a diferença de produtividade entre os dois sistemas torna-se mais vantajoso a utilização do sequeiro, ressaltando a incidência de veranicos que necessitaria da utilização da irrigação de salvação.

\section{REFERÊNCIAS}

[1] ALLEN, R. G.; PEREIRA, L. S; RAES, D.; SMITH, M. Crop evapotranspiration - Guidelines for computing crop water requirements. (Irrigation and Drainage Paper, 56). Rome: FA0, 1998. Disponível em:< http://www.fao.org/docrep/X0490E/X0490E00.htm> Acesso em 18- 11-2010.

[2] ANDRIOLI, Kleber Gustavo ; SENTELHAS, P. C. ; SOLER, Cecilia Manuela Tojo ; MARIN, Fábio Ricardo . Calibração do modelo da FAO para a simulação da produtividade potencial e real do milho safrinha. In: Congresso Brasileiro de Meteorologia, 2006, Florianópolis. A meteorologia a serviço da sociedade. Rio de Janeiro : Sociedade Brasileira de Meteorologia, 2006.v. 1.

[3] BARROS, H.C.B. Desenvolvimento de funções de pedotransferência e sua utilização em modelo agrohidrológico. 2010. 148 p.Tese (Doutorado em Ciências). Escola Superior de Agricultura "Luiz de Queiroz". Universidade de São Paulo. Piracicaba, SP. 2010.

[4] CINTRA, F.L.D.; LIBARDI, P.L.; SAAD, A.M. Balanço hídrico no solo para porta-enxertos de citros em ecossistema de Tabuleiro Costeiro. Revista Brasileira de Engenharia Agrícola e Ambiental, v. 4, n. 1, p. 23-28, 2000. 
[5] D’ANGIOLELlA, G. \& VASCONCELlOS, V.L.D. Planilha eletrônica para cálculo do balanço hídrico climatológico normal utilizando diferentes métodos de estimativa da evapotranspiração potencial. Revista Brasileira de Agrometeorologia, Santa Maria, v. 11, n. 2, p. 375-378, 2003

[6] DOORENBOS, J.; KASSAM, A. H.; BENTVELSEN, C. L. M.; BRANSCHEID, V.; PLUSJÉ, J.M.G.A.;

[7] SMITH, M.; UITTENBOGAARD, G.O.; VAN DER WAL, H. K. Yield response to water. (Irrigation and Drainage Paper, 33) Rome: FAO, 193p. 1979.

[8] GODOY, A.P. Modelagem de processos de acumulação de biomassa e de açúcar da cana- de-açúcar via sistemas nebulosos. 2007. 254 p. Dissertação (Mestrado em Engenharia Elétrica) - Faculdade de Engenharia Elétrica e Computação, Universidade Estadual de Campinas, Campinas, 2007.

[9] Hargreaves, G.H., and Allen, R.G., 2003: History and evaluation of Hargreaves evapotranspiration equation. J. Irrig. Drain. Eng.,129(1), 53-63.

[10] Hillel, D. Solo e água: Fenômenos e princípios físicos. Porto Alegre: UFRGS, Departamento de Solos, 1970. 231p.

[11] HEINEMANN, A.B.; SILVA, S.C. da; LOPES JUNIOR, S.; AMORIM, A.O.; ANDRADE, C.L.T.;BASTOS,E.A.; PAZ, R.L.F.. da. Características climáticas dos municípios de Santo Antonio de Gois (GO), Janaúba, (MG), Sete Lagoas (MG), Parnaiba (PI).Santo Antonio de Goiás: Embrapa Arroz e Feijão.2007. 36p. (Documentos, 214).

[12] HEXEM, R.W.; HEARY, E.O. Water productions fuctions for irrigated agriculture. lowa: The lowa State University Press, 1978. 215p.

[13] JAMIESON, P.D.; PORTER JR.; WILSON, D.R. A test of the computer simulation model ARC- WHEAT1 on wheat crops grown in New Zeland. Field Crops Research, v.27, p.337-350. 1991.

[14] JONES, J. W., RITCHIE, J. T. Crop growth models. In: HOFFMAMN, G.L. et al. (Ed.). Management of farm irrigation system. S.L., 1990. p.63-89.

[15] LIBARDI, P.L. Dinâmica da água no solo. 1.ed. Piracicaba: O autor, 1995. 509p.

[16] Oliveira, R. A.; Santos, R. S.; Ribeiro, A.; Zolnier, S.; Barbosa, M. H. P. Estimativa da produtividade da canade-açúcar para as principais regiões produtoras de Minas Gerais usando-se o método ZAE. Revista Brasileira de Engenharia Agrícola e Ambiental, v.16, p.549-557, 2012.

[17] PEREIRA, A.R.; VILLA NOVA, N.A.; SEDIYAMA, G.C. Evapotranspiração. Piracicaba: FEALQ. 1997. 183p.

[18] SEDIYAMA, G.C.; LEAL, B.G.; MANTOVANI, E.C.; COSTA, L.C.; BASTOS, L.N. Sistema para Manejo da Água em Áreas Irrigadas e Estimativa do Rendimento de Culturas Agrícolas. Universidade Federal de Viçosa. 2001. Disponível em: $\quad<$ http://www.grupointec.com.br/grupo/es/Sistema\%20para\%20manejo\%20da\%20ag ua $\% 20 \mathrm{em} \% 20$ areas $\% 20$ irrigadas $\% 20 \mathrm{e} \% 20$ estimativa $\% 20 \mathrm{do} \% 20$ rendimento $\% 20 \mathrm{~d}$ \%20culturas\%20agricolas\%20\%20cag\%20\%202585-97.pdf >. Acesso em 10/08/2011.

[19] THORNTHWAITE, C. W.; MATHER, J. R. The water balance. New Jersey: Laboratory of climatology, 104 p. 1955.(Publication in Climatology, 8).

[20] WILLMOTT, C.J.; ACKLESON, S.G.; DAVIS, R.E.; FEDDEMA, J.J.; KLINK, K.M.; LEGATES, D.R.;

[21] O'DONNELL, J.; ROWE, C.M. Statistics for the evaluation and comparison of models. Journal of Geophysical Research, v.90, p.8995-9005, 1985.

[22] SANTOS, R.S.; COSTA, L.C.; SEDIYAMA, G.C.; LEAL, B.G.; OLIVEIRA, R.A.; JUSTINO, F.B. Avaliação da relação seca/produtividade agrícola em cenário de mudanças climáticas. Revista Brasileira de Meteorologia, v.26, n.2, 313 321,2011 


\section{ANEXOS}

Anexo 01: Produtividade do Sorgo no Perímetro Irrigado Jacarecica I

\begin{tabular}{|c|c|c|c|c|}
\hline & \multicolumn{4}{|c|}{ Produtividade } \\
\hline & SEQ & IRR & DESVPAD & $\mathrm{CV}$ \\
\hline $01 / 01 / 2004$ & 2364,59 & 4246,75 & 609,688 & 25,78413 \\
\hline $11 / 01 / 2004$ & 2464,76 & 4303,31 & 459,4436 & 18,64048 \\
\hline $21 / 01 / 2004$ & 2644,51 & 4319,21 & 532,0352 & 20,11848 \\
\hline $31 / 01 / 2004$ & 2748,07 & 4235,10 & 475,9352 & 17,31889 \\
\hline $10 / 02 / 2004$ & 2909,85 & 4166,18 & 511,7722 & 17,5876 \\
\hline $20 / 02 / 2004$ & 3059,95 & 4104,83 & 530,1101 & 17,32414 \\
\hline $01 / 03 / 2004$ & 3219,41 & 4004,09 & 570,9271 & 17,73392 \\
\hline $11 / 03 / 2004$ & 3415,28 & 4007,96 & 566,2584 & 16,58017 \\
\hline $21 / 03 / 2004$ & 3532,21 & 3970,13 & 492,9208 & 13,95501 \\
\hline $31 / 03 / 2004$ & 3578,59 & 3842,19 & 460,1977 & 12,85974 \\
\hline $10 / 04 / 2004$ & 3617,62 & 3785,01 & 385,7534 & 10,66319 \\
\hline $20 / 04 / 2004$ & 3561,94 & 3728,23 & 371,9011 & 10,44096 \\
\hline $30 / 04 / 2004$ & 3561,61 & 3707,32 & 333,4602 & 9,362619 \\
\hline $10 / 05 / 2004$ & 3486,89 & 3673,09 & 306,4239 & 8,787874 \\
\hline $20 / 05 / 2004$ & 3412,19 & 3646,65 & 260,7038 & 7,640378 \\
\hline $30 / 05 / 2004$ & 3388,04 & 3648,78 & 264,1828 & 7,797512 \\
\hline $09 / 06 / 2004$ & 3388,85 & 3668,71 & 331,843 & 9,792212 \\
\hline $19 / 05 / 2004$ & 3232,51 & 3658,88 & 409,8816 & 12,68 \\
\hline $29 / 06 / 2004$ & 2926,40 & 3681,55 & 480,6282 & 16,42388 \\
\hline $09 / 07 / 2004$ & 2697,00 & 3751,82 & 459,1163 & 17,02322 \\
\hline $19 / 07 / 2004$ & 2396,68 & 3784,57 & 615,7617 & 25,69228 \\
\hline $29 / 07 / 2004$ & 2097,23 & 3779,27 & 577,8691 & 27,55389 \\
\hline $08 / 08 / 2004$ & 1922,34 & 3808,41 & 572,3065 & 29,77141 \\
\hline $18 / 08 / 2004$ & 1826,65 & 3861,57 & 524,0653 & 28,68989 \\
\hline $28 / 08 / 2004$ & 1675,52 & 3824,43 & 410,8873 & 24,52297 \\
\hline $07 / 09 / 2004$ & 1577,75 & 3734,81 & 488,4295 & 30,95734 \\
\hline $17 / 09 / 2004$ & 1553,43 & 3760,63 & 465,4268 & 29,96129 \\
\hline $27 / 09 / 2004$ & 1505,22 & 3760,30 & 525,3766 & 34,90374 \\
\hline $07 / 10 / 2004$ & 1376,33 & 3810,86 & 439,6644 & 31,9447 \\
\hline $17 / 10 / 2004$ & 1421,95 & 3945,85 & 491,0377 & 34,53273 \\
\hline $27 / 10 / 2004$ & 1466,94 & 3983,96 & 475,4912 & 32,4138 \\
\hline $06 / 11 / 2004$ & 1585,48 & 4102,27 & 451,306 & 28,46488 \\
\hline $16 / 11 / 2004$ & 1632,34 & 4181,21 & 365,5999 & 22,39723 \\
\hline $26 / 11 / 2004$ & 1655,61 & 4131,18 & 369,5347 & 22,3201 \\
\hline $06 / 12 / 2004$ & 1814,01 & 4278,29 & 433,0584 & 23,87297 \\
\hline $16 / 12 / 2004$ & 1962,19 & 4299,34 & 453,1625 & 23,09471 \\
\hline $26 / 12 / 2004$ & 2153,03 & 4213,03 & 524,7364 & 24,37205 \\
\hline
\end{tabular}




\title{
CAPÍTULO 10 \\ Comitê da bacia hidrográfica do rio Sergipe (CBHS): Aspectos Legais e Estruturantes na Gestão das Águas.
}

\author{
Ângela Maria do Nascimento Lima \\ Eduardo Lima Matos \\ Marcos Cabral de Vasconcellos Barretto
}

\section{INTRODUÇÃO}

Abordar temas relacionados às leis envolvendo as questões ambientais, em especial dos recursos hídricos, requer um estudo cauteloso e preciso. A Constituição Federal de 1988 possui um importante papel para a gestão dos recursos hídricos, ao estabelecer um novo conceito das águas para o país e alterar a dominialidade das águas do território nacional. Esta anteriormente era definida pelo Código de Águas mediante o Decreto No 24.643, de 10 de julho de 1934.

Agora, em seu Art. 20, inciso III, a Constituição estabelece que sejam bens da União: "os lagos, rios e quaisquer correntes de água em terrenos do seu domínio, ou que banhem mais de um Estado, sirvam de limites com outros países, se estendam a território estrangeiro, ou dele provenham, bem como terrenos marginais e as praias fluviais".

Outra atribuição de grande relevância para o país também foi estabelecida pela Constituição de 1988 em seu Art. 21, inciso XIX, que determina "instituir sistema nacional de gerenciamento de recursos hídricos e definir critérios de outorga de direitos de uso". 0 artigo constitucional originou a Lei 9.433, de 08 de janeiro de 1997, a qual instituiu a Política Nacional de Recursos Hídricos e criou o Sistema Nacional de Gerenciamento de Recursos Hídricos.

A partir da aprovação desta Lei, o país passa a dispor de um instrumento legal que visa garantir às gerações presentes e futuras a disponibilidade dos recursos hídricos. Além disso, concretiza-se a modernização do setor e coloca o Brasil entre os países que possui uma das legislações mais avançadas do mundo no setor de recursos hídricos, ocorrendo com base nesta Lei a criação dos Comitês de Bacias Hidrográficas.

O Comitê de Bacia Hidrográfica é um órgão colegiado, inteiramente novo na realidade institucional brasileira, contando com a participação dos usuários, da sociedade civil organizada, de representantes de governos municipais, estaduais e federal. Esse ente é destinado a atuar como "parlamento das águas", posto que é o fórum de negociação no âmbito de cada bacia hidrográfica. Os Comitês de Bacias Hidrográficas têm, entre outras, as atribuições de: promover o debate das questões relacionadas aos recursos hídricos da bacia; articular a atuação das entidades que trabalham com este tema; arbitrar, em primeira instância os conflitos relacionados a recursos hídricos; aprovar e acompanhar a execução do Plano de Recursos Hídricos da Bacia; estabelecer os mecanismos de cobrança pelo uso de recursos hídricos e sugerir os valores a serem cobrados; estabelecer critérios e promover o rateio de custo das obras de uso múltiplo, de interesse comum ou coletivo.

Nesse contexto, o presente trabalho tem como objetivo apresentar o embasamento legal da formação e existência do Comitê de Bacia Hidrográfica do Rio Sergipe, destinado a promover ação efetiva do controle social do uso das águas, como patrimônio coletivo com a participação de todos os segmentos da sociedade. 


\section{GESTÃO DOS RECURSOS HÍDRICOS}

A situação das águas no Brasil abrange problemas de qualidade e quantidade. Nas próximas décadas o país enfrentará desafios específicos no que se referente à gestão das águas. É estimada no Brasil uma concentração entre $12 \%$ a $16 \%$ de volume de água do planeta, porém em má distribuição, e esse percentual está ameaçado por fatores diversos nas áreas socioeconômicas. (CLARKE, ROBIN, 2005)

Um dos principais desafios, no que diz respeito à gestão dos recursos hídricos é o de garantir

o suprimento adequado de água nos pequenos municípios e nas regiões metropolitanas, onde, além da escassez, os recursos hídricos são constantemente contaminados pelos esgotos domésticos e industriais; Para solucionar os problemas são necessários avanços tecnológicos, institucionais e implantação de sistema de gestão integrada e participativa.

É importante, para isso, a introdução de novos paradigmas, como a gestão das águas que inclui as águas superficiais, subterrâneas e águas atmosféricas que serão otimizados pelos usos múltiplos e aproveitamento integral das águas disponíveis, incluindo o reuso, tratamento adequado e de baixo custo e a economia das águas.

A gestão por bacias hidrográficas é um modelo de administração integrada que ultrapassa fronteiras e possibilita o uso racional dos recursos hídricos. Este modelo promove técnicas inovadoras para manter a sustentabilidade e elabora um planejamento estratégico que une o planejamento territorial com a gestão das bacias e dos recursos hídricos superficiais e subterrâneos. (CLARKE, ROBIN, 2005).

A gestão dos recursos hídricos deve sempre proporcionar o uso múltiplo das águas e tomar como referência de unidade territorial, a bacia hidrográfica, atuando de forma descentralizada e contando com a participação do Poder Público, dos Usuários e da Sociedade Civil Organizada, como está estabelecido na Lei Federal № 9.433/97.

A participação dos diversos órgãos e entidades para atuar na gestão dos recursos hídricos, será integrada através do Sistema, palavra que se originou do Grego e significa "conjunto". Portanto, em seu Art.32, a Lei № 9.433/97 fixa os objetivos do Sistema Nacional de Gerenciamento de Recursos Hídricos, a saber:

I- coordenar a gestão integrada das águas; II - arbitrar administrativamente os conflitos relacionados com os recursos hídricos; III - implementar a Política Nacional de Recursos Hídricos; IV - planejar, regular e controlar o uso, a preservação e a recuperação dos recursos hídricos; $\mathrm{V}$ - promover a cobrança pelo uso de recursos hídricos"(BRASIL,1997).

E em seu Art.33. a Lei 9.433/97 estabelece a composição do Sistema:

I - o Conselho Nacional de Recursos Hídricos; I-A. - a Agência Nacional de Águas; II - os Conselhos de Recursos Hídricos dos Estados e do Distrito Federal; III - os Comitês de Bacia Hidrográfica; IV - os órgãos dos poderes públicos federal, estaduais, do Distrito Federal e municipais cujas competências se relacionem com a gestão de recursos hídricos; V - as Agências de Água"(BRASIL,1997).

o Conselho Nacional de Recursos Hídricos (CNRH), através da Resolução no 05, de 10 de abril de 2000, estabelece diretrizes para formação e funcionamento dos Comitês de Bacia Hidrográfica de domínio da União, representando um avanço na participação da sociedade civil nos Comitês, (MACHADO, 2002).

O Conselho Nacional de Recursos Hídricos autoriza as agências de águas, ou as entidades delegatárias com funções de Agência, para funcionar como secretarias executivas de um ou mais comitês de bacia. A criação das agências de águas está condicionada à comprovação prévia da sua viabilidade financeira, assegurada pela cobrança pelo uso da água na respectiva bacia, (BRASIL, 2013). Depois da aprovação da Lei № 9.433/97, onze estados elaboraram suas políticas de recursos hídricos, dentre estes, Sergipe, que a institucionalizou mediante a Lei Estadual № 3.870 de 25 de setembro de 1997, refletindo as diretrizes definidas pela Política Nacional de Recursos Hídricos. (SERGIPE, 2002).

A implementação da Política Estadual de Recursos Hídricos com o conjunto de órgãos e entidades que exercem atividades na gestão dos recursos hídricos em Sergipe faz parte do Sistema Estadual de Gerenciamento de Recursos Hídricos estabelecido pela Lei Estadual e tem como objetivos: coordenar a gestão integrada das águas; arbitrar em instâncias administrativas dos conflitos relacionados com os recursos hídricos; planejar, regular e controlar o uso, a preservação e a recuperação dos recursos hídricos e promover a cobrança pelo uso de recursos hídricos (SERGIPE, 2002). 
Para gerir os recursos hídricos a Lei Estadual prevê os seguintes instrumentos: implantação do Plano Estadual de Recursos Hídricos; enquadramento dos corpos de água em classes, segundo os usos preponderantes da água; a criação do Fundo Estadual de Recursos Hídricos; a regulamentação da outorga dos direitos de uso de recursos hídricos; a implantação da cobrança pelo uso de recursos hídricos; e criação do Sistema Estadual de Informações sobre Recursos Hídricos, (SERGIPE, 2002).

Os órgãos e entidades que integram o Sistema Estadual de Gerenciamento de Recursos Hídricos são os seguintes: o Conselho Estadual de Recursos Hídricos - CONERH/SE; os Comitês de Bacia Hidrográfica CBHs; a Secretaria de Estado do Meio Ambiente e dos Recursos Hídricos - SEMARH; os órgãos dos poderes públicos federal, estadual e municipal, cujas competências se relacionem com a gestão de recursos hídricos e as Agências de Água, (SERGIPE, 2002).

O CONERH/SE foi constituído pelo Decreto № 18.099 de 25 de junho de 1999 com as seguintes funções: planejamento do uso de recursos hídricos nos diversos segmentos da sociedade; aprovar o Plano Estadual de Recursos Hídricos e determinar as providências; arbitrar, em última instância administrativa, os conflitos existentes entre bacias hidrográficas e usuários de água; analisar propostas de alteração da legislação pertinente a recursos hídricos e à Política Estadual de Recursos Hídricos; estabelecer critérios gerais para a outorga de direitos de uso de recursos hídricos e para cobrança por seu uso e aprovar propostas de constituição dos Comitês de Bacias Hidrográficas, (SERGIPE, 2002).

Os Comitês das Bacias Hidrográficas são abordados na legislação estadual nos artigos: 3839 e 40 referentes à atuação, atribuições e composição. Os comitês são órgãos consultivos e deliberativos, tendo como objetivo principal a gestão dos recursos hídricos. A sua competência é aprovar e acompanhar a elaboração e execução dos planos de bacia; aplicação dos recursos financeiros na conservação, proteção e recuperação dos recursos hídricos e negociação dos conflitos pelo uso da água. E para negociar os conflitos pelo uso da água, o Comitê será composto conforme estabelece o Art.40 da Lei Estadual № 3.870/97, de:

...representantes de órgãos e entidades públicos com interesses na gestão, oferta, controle, proteção e uso dos recursos hídricos, bem como representantes dos Municípios contidos na Bacia Hidrográfica correspondente e dos usuários das águas através das entidades associativas" (SERGIPE, 1997).

\section{PROCEDIMENTOS METOdOLÓGICOS}

A pesquisa tem caráter qualitativo. Utilizou-se metodologia de pesquisa documental como teses, monografias, dissertações, artigos e visitas in loco ao órgão gestor do Estado: Secretaria Estadual do Meio Ambiente e dos Recursos Hídricos (SEMARH) através da Superintendência de Recursos Hídricos (SRH) e da secretaria executiva do Comitê da Bacia Hidrográfica do rio Sergipe. Foram coletados dados junto ao site da Agência Nacional da Água (ANA).

\subsection{CARACTERIZAÇÃO DA ÁREA EM ESTUDO}

0 estado de Sergipe é composto por 08 Bacias Hidrográficas (Figura 01): Rio São Francisco, Rio Vaza Barris, Rio Real, Rio Japaratuba, Rio Sergipe, Rio Piauí, Grupo de Bacias Costeiras 01 (GC1) e Grupo de Bacias Costeiras 02 (GC2). Os rios Japaratuba, Sergipe e Piauí são rios de domínio do Estado, pois suas bacias estão dentro do Estado de Sergipe, exceto por uma pequena área dos rios Sergipe e Piauí, que recobre terras baianas. Cada uma das bacias possui características próprias e um fato em comum: precisam de cuidados. (SEMARH-SRH, 2012).

A Bacia Hidrográfica do rio Sergipe é composta pelo rio Sergipe que percorre aproximadamente $210 \mathrm{~km}$, desde suas nascentes, em Nossa Senhora da Glória; até desaguar no Oceano Atlântico em Aracaju, tendo como principais afluentes pela margem esquerda os rios Pomonga, Parnamirim, Ganhamoroba e Cágado; e pela margem direita os rios Poxim, Sal, Cotinguiba, Jacarecica, Morcego, Jacoca, Campanha, Lages e Melancia. Encontra-se definida pelos seguintes limites geográficos: ao norte, com a Bacia Hidrográfica do rio São Francisco; ao leste, com a Bacia Hidrográfica do rio Japaratuba; ao sul e ao oeste, com a Bacia Hidrográfica do rio Vaza Barris, (SERGIPE, 2002). 
Figura 01. Bacias Hidrográficas do estado de Sergipe

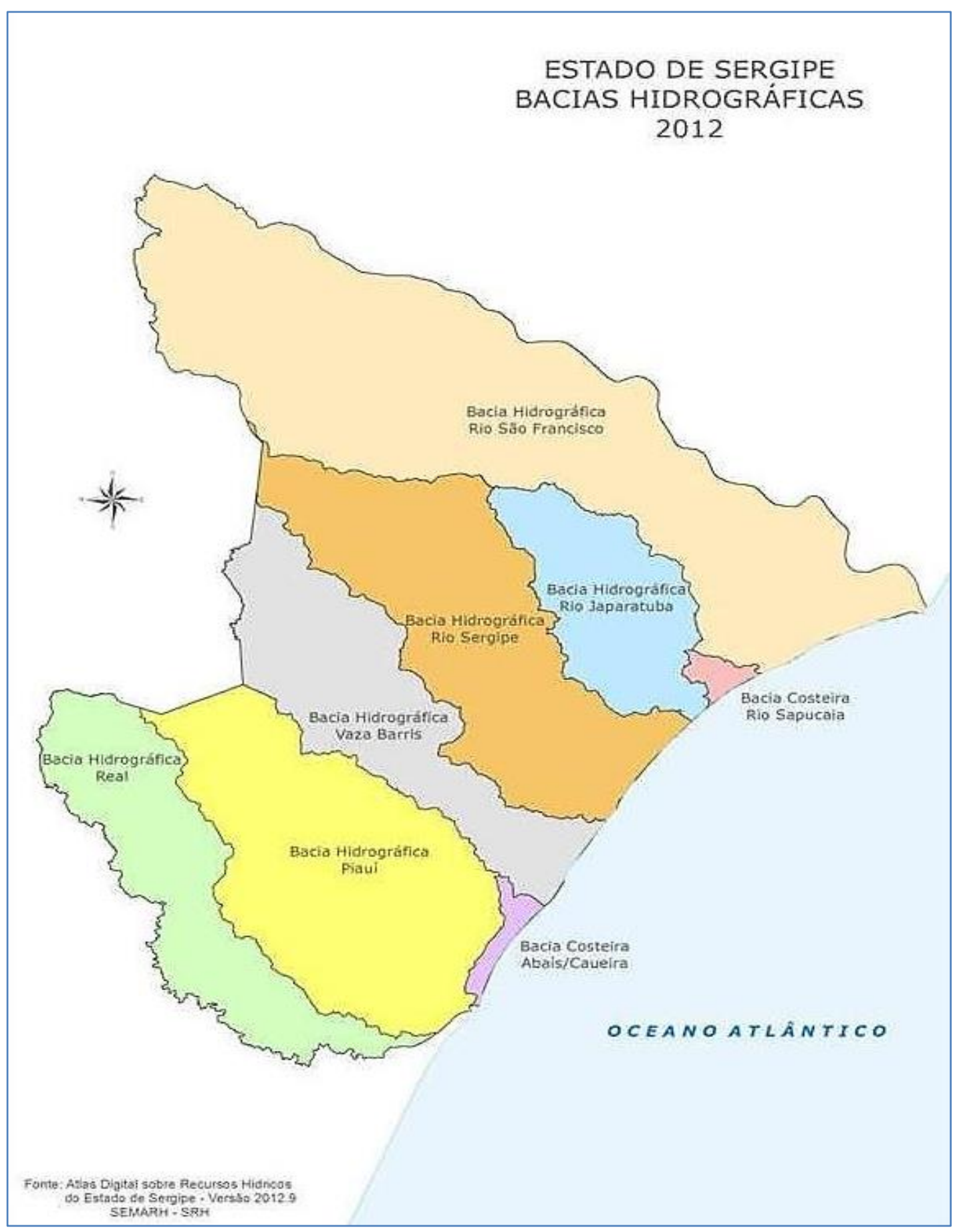

Fonte: Sergipe, (2012)

Esta bacia abrange 26 municípios, sendo oito inseridos totalmente na bacia, que são os seguintes: Laranjeiras, Malhador, Moita Bonita, Nossa Senhora Aparecida, Nossa Senhora do Socorro, Riachuelo, Santa Rosa de Lima e São Miguel do Aleixo. Dezoito municípios são parcialmente inseridos na Bacia, a saber: Aracaju, Areia Branca, Barra dos Coqueiros, Carira, Divina Pastora, Feira Nova, Frei Paulo, Graccho Cardoso, Itabaiana, Itaporanga d'Ajuda, Maruim, Nossa Senhora da Glória, Nossa Senhora das Dores, Ribeirópolis, Rosário do Catete, Santo Amaro das Brotas, São Cristóvão e Siriri. (SERGIPE, 2002)

A população residente é de 1.010.523 habitantes, equivalendo a 56,6\% do total do Estado. A maioria expressiva da população, 86,8\%, reside em áreas urbanas, ao passo que 13,2\% situam-se na zona rural, fato que comprova o acelerado processo de urbanização em curso na bacia hidrográfica nas últimas 
décadas, responsável pelo grande passivo ambiental da região e uma significativa transposição de águas provenientes do Rio São Francisco, (SERGIPE, 2002).

Os diversos usos das águas da Bacia Hidrográfica como irrigação, mineração, indústria, consumo humano e animal, pesca artesanal, turismo e lazer estão associados às atividades econômicas, ligados aos setores privado e público, bem como, os principais sistemas hídricos, naturais e construídos, possibilitam o desenvolvimento da região.

\section{IMPLANTAÇ̃̃O DO COMITÊ DA BACIA HIDROGRÁFICA DO RIO SERGIPE}

A Bacia Hidrográfica do Rio Sergipe foi selecionada como piloto em virtude da importância regional no contexto político, econômico, social e cultural do Estado. Para implantação do comitê realizou-se encontros nos quais foram indicados articuladores municipais para subsidiar o processo de mobilização para a gestão participativa. As informações sobre os Encontros Regionais realizados na Bacia Hidrográfica do Rio Sergipe foram detalhadas e, em seguida, promovida uma oficina de planejamento com a participação de órgãos públicos, usuários de água e organizações da sociedade civil. A finalidade dessa oficina foi ampliar os conhecimentos e constituir o comitê da bacia hidrográfica do rio Sergipe, (SERGIPE, 2002).

Figura 02. Mapa de localização da Bacia Hidrográfica do rio Sergipe

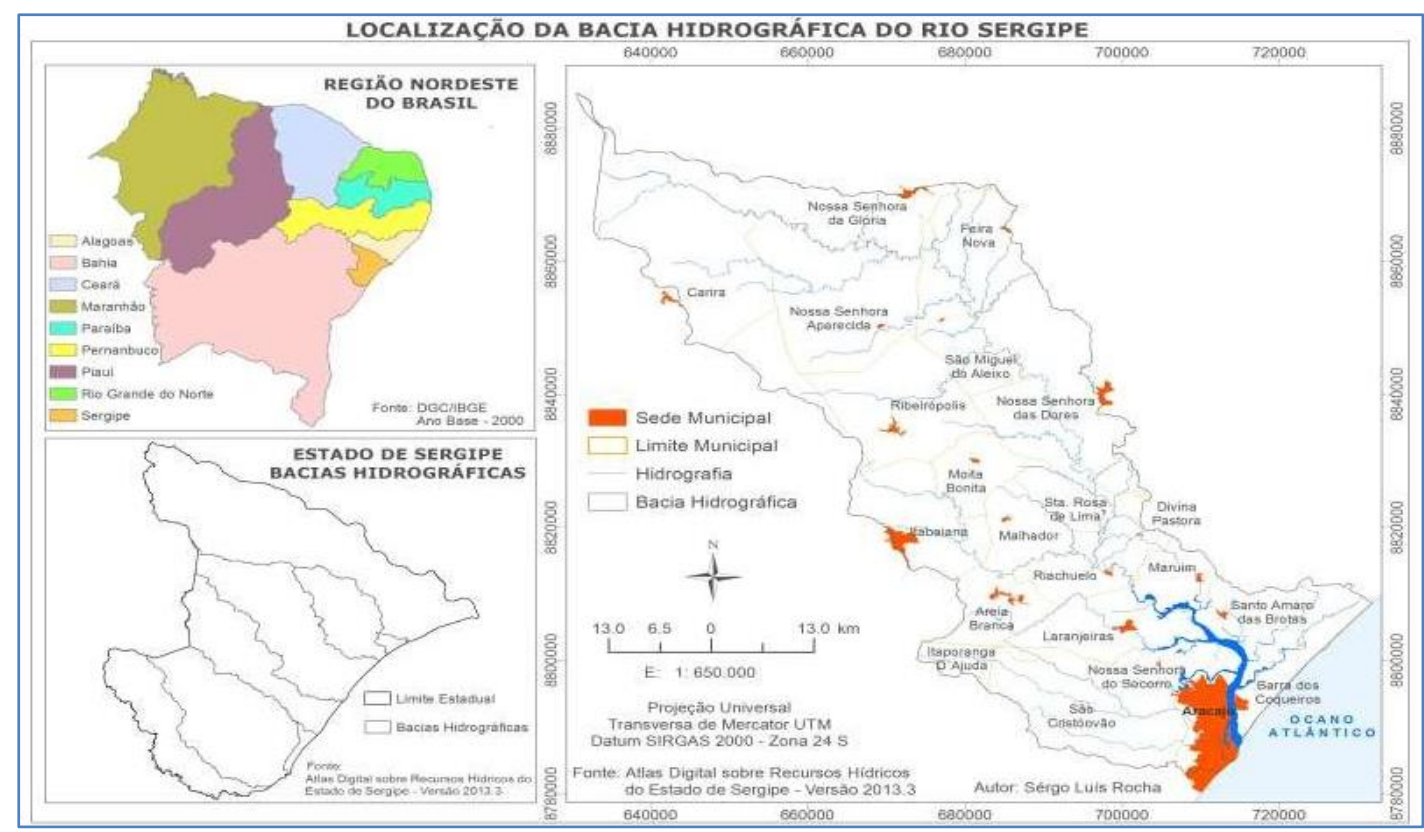

Fonte: Atlas Digital Sergipe, (2013).

A metodologia adotada pelo Programa Estadual de Apoio à Gestão Participativa consistiu na formação do Comitê Técnico de Acompanhamento, composto por 15 representantes de diversos órgãos, tendo por finalidade fortalecer a ação interinstitucional para o gerenciamento integrado. Em seguida, foi formulado calendários de visitas aos municípios, com objetivo de elaborar a caracterização da bacia, construção do plano de trabalho com realização de encontros municipais e regionais tendo por objetivos divulgar a Política Estadual de Recursos Hídricos, sensibilizar e mobilizar a sociedade para a problemática hídrica e ambiental, assim como aprofundar o diagnóstico preliminar como instrumento de apoio à organização e participação social, (SERGIPE, 2002).

Em 09 de abril de 2002, o CONERH/SE aprova a constituição do Comitê da Bacia Hidrográfica do rio Sergipe, (CBHS), através da Resolução № 02/2002 e autoriza a elaboração e aprovação do Regimento Interno. O comitê foi oficializado pelo Decreto Estadual № 20.778 de 21 de junho de 2002. (SERGIPE, 2002). O CBHS previa em seu Regimento Interno no ato de sua instalação, a diretoria composta por Presidente e Secretário com mandato para dois anos, e a composição atendia $50 \%$ de representantes do poder público e $50 \%$ o somatório dos representantes dos usuários e da sociedade civil. Eram 
convocadas seis reuniões ordinárias por ano; devendo ser tratados somente assuntos que constavam na pauta de convocação, com o quorum mínimo de metade mais um de seus membros, para discussões, deliberações, resoluções e encaminhamentos.

A Resolução № 15/2012, do CONERH deliberou as diretrizes de funcionamento dos Comitês das Bacias Hidrográficas do estado de Sergipe. A partir dessa Resolução, os comitês passaram a ter um mandato de três anos, diretoria composta por: Presidente, Vice presidente e Secretário geral, composição paritária com 24 membros distribuídos da seguinte forma: 08 representantes da Sociedade Civil organizada, 08 representantes do Poder Público e 08 representantes dos Usuários de água bruta, conforme apresentado no Quadro 01. Cabe ao CONERH estabelecer normas e diretrizes de funcionamento e encaminhar para o Chefe do Poder Executivo Estadual decretar a renovação dos membros da instituição e aos Comitês de Bacias cabe a aprovação dos seus Regimentos Internos. (SERGIPE, 2012).

\section{Quadro 01: Composição do Comitê CBHS}

\begin{tabular}{|c|c|c|}
\hline \multicolumn{3}{|c|}{ SEGMENTOS } \\
\hline Usuários de Água & Sociedade Civil & Poder Público \\
\hline $\begin{array}{l}02 \text { (dois) representantes da } \\
\text { indústria e mineração; }\end{array}$ & $\begin{array}{l}02 \text { (dois) representantes eleitos } \\
\text { das instituições de ensino e } \\
\text { pesquisa; }\end{array}$ & \multirow{4}{*}{$\begin{array}{l}01 \text { (um) representante da esfera } \\
\text { federal; } \\
\text { 01(um) representante da SEMARH; } \\
\text { 01(um) representante da Secretaria } \\
\text { de Estado da Agricultura, } \\
\text { Abastecimento e Irrigação - SEAGRI; } \\
\text { 01(um) representante da Secretaria } \\
\text { de Estado do Planejamento, } \\
\text { Orçamento e Gestão - SEPLAG; } \\
\text { 03(três) representantes do Poder } \\
\text { Executivo Municipal; } \\
01 \text { (um) representante do Poder } \\
\text { Legislativo Municipal. }\end{array}$} \\
\hline $\begin{array}{l}02 \text { (dois) representantes da } \\
\text { atividade pesca, turismo e lazer; }\end{array}$ & $\begin{array}{l}01(\mathrm{um}) \text { representante eleito da } \\
\text { categoria profissional; }\end{array}$ & \\
\hline $\begin{array}{l}02 \text { (dois) representantes de } \\
\text { abastecimento urbano e } \\
\text { lançamento de efluentes; }\end{array}$ & $\begin{array}{l}\text { 04(quatro) representantes eleitos } \\
\text { das organizações não } \\
\text { governamentais legalmente } \\
\text { constituídas e comprovada } \\
\text { atuação no âmbito da Bacia; }\end{array}$ & \\
\hline $\begin{array}{l}02 \text { (dois) representantes de } \\
\text { agricultura e irrigação; }\end{array}$ & $\begin{array}{l}01(\mathrm{um}) \text { representante eleito de } \\
\text { comunidades tradicionais; }\end{array}$ & \\
\hline
\end{tabular}

Fonte: SERGIPE, (2012).

\subsection{ESTRUTURA DO COMITÊ DA BACIA HIDROGRÁFICA DO RIO SERGIPE}

A estrutura do CBHS é composta pelo Plenário, que composto do conjunto dos membros do comitê reunidos em assembléia geral e configura-se como instância máxima. Diretoria Executiva do CBHS atualmente é gerida por: presidente, vice - presidente e secretário geral assessorado pela secretariaexecutiva, esta com estrutura mínima, um técnico, apoio administrativo, técnico, logístico e operacional do órgão gestor, a SEMARH/SE. A estrutura do CBHS está apresentada na Figura 03. 
Figura 03. Estrutura do CBHS.

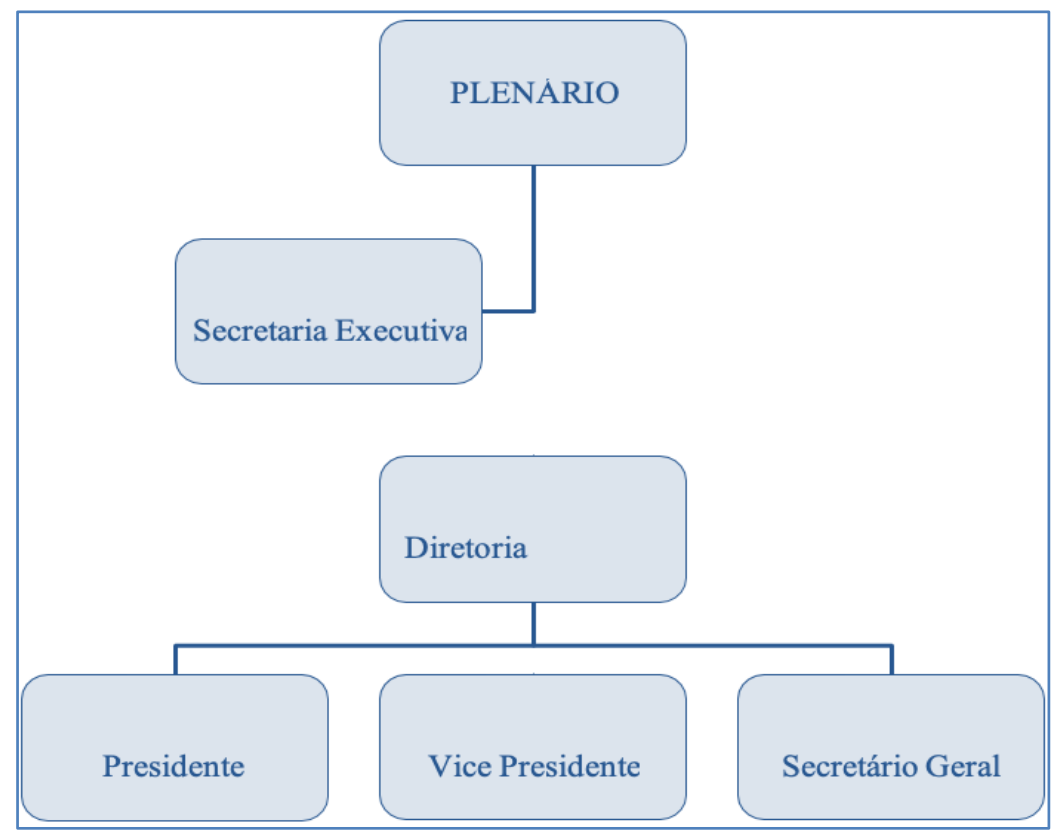

Fonte: SERGIPE (2012).

Com a aplicação das diretrizes deliberadas pelo CONERH, as reuniões ordinárias passaram a ocorrer quatro vezes por ano, por convocação do Presidente com antecedência mínima de quinze dias; e extraordinariamente, sempre que necessário devendo ser tratados somente assuntos que constam na pauta da convocação. No momento das reuniões deverá ser lida a ordem do dia seguida de deliberações e resoluções definidas pela plenária, como consta na Figura 04.

Figura 04. Ordem do dia: reuniões ordinárias e extraordinárias do CBHS.

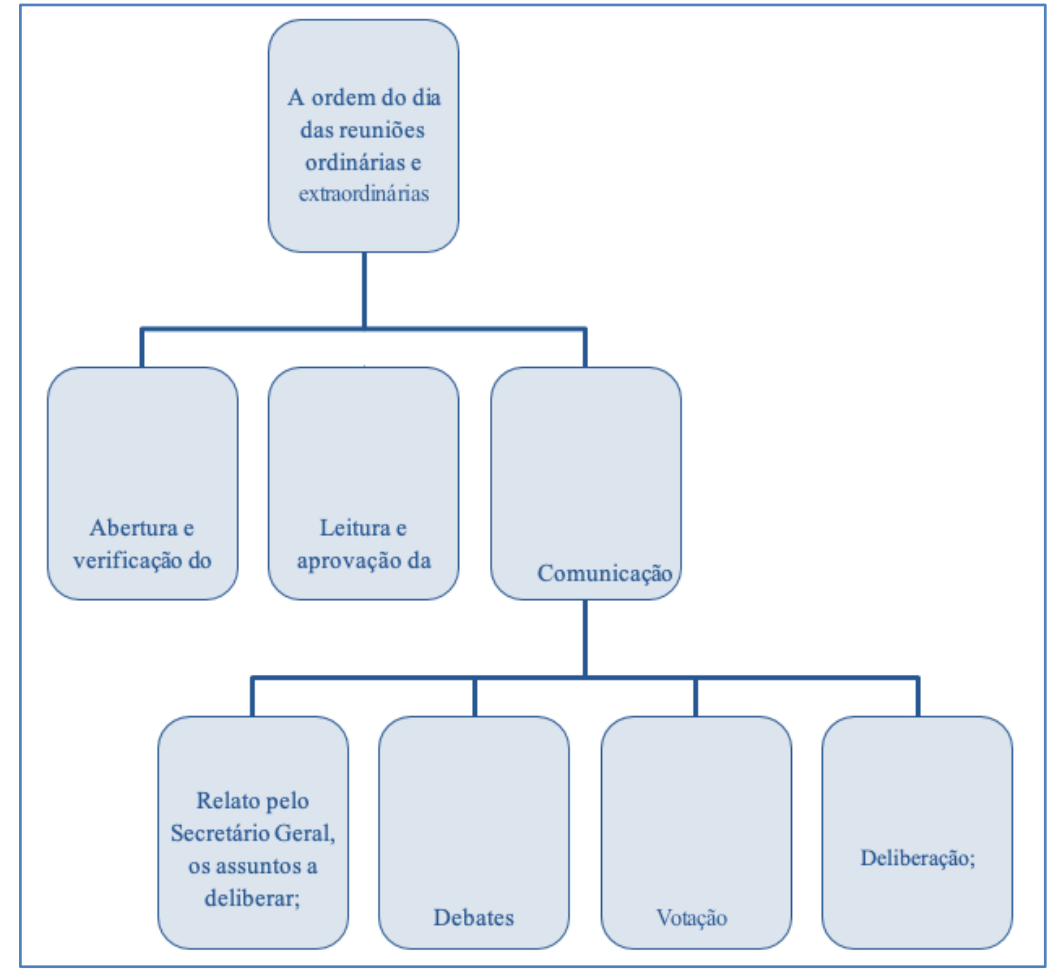

Fonte: SERGIPE (2012) 


\subsection{PROCESSO DE RENOVACC̃̃O DOS MEMBROS}

A cada três anos ocorrerão o processo de renovação dos membros do Comitê, procedendo da seguinte maneira: eleição da comissão eleitoral, elaboração do edital de convocação constando o cronograma de ações. Para execução do processo eleitoral farão parte representante das instituições da Sociedade Civil Organizada, dos Usuários de água e do Poder Público Municipal executivo e legislativo. O poder público estadual e federal terão vagas natas e seus representantes serão indicados pelos dirigentes legítimos. Após as eleições setoriais haverá posse dos membros e eleição da Diretoria Executiva do Comitê por seus pares, para um mandato de 03 (três) anos, permitindo a recondução por mais um período. Todos os integrantes do Comitê deverão ter plenos poderes de representação dos órgãos ou entidades de origem.

Segundo o Regimento Interno, cabe à Diretoria do CBHS, além das atribuições estabelecidas coordenar o processo de renovação, com a Comissão Eleitoral eleita em plenária, conforme Parágrafo Único do Art. 49.

Parágrafo Único: promover a criação de Comissão Eleitoral de Renovação do CBH, de caráter tripartite, através da escolha em reunião plenária, a ser convocada com item de pauta específico para esse fim".

Art. 50. A Comissão Eleitoral de Renovação do CBH a que se refere o Parágrafo Único do Art. 49o deste Regimento poderá ser constituída por membros do respectivo Comitê ou por outros órgãos e entidades com atuação na respectiva bacia, indicados e aprovados pelo plenário".

\section{CONSIDERAÇõES FINAIS}

O Comitê da Bacia Hidrográfica do rio Sergipe, objeto de estudo deste artigo, completou 10 anos de funcionamento sendo um espaço de negociação de conflitos dos recursos hídricos, tem abrangência em 26 municípios da Bacia e somente 50\% destes participaram da composição do Comitê, necessitando de mobilização contínua e divulgação nas rádios comunitárias, mesmo ocorrendo reuniões itinerantes frequentes.

Com relação à atividade de negociação de conflitos, foram criados Câmaras Técnicas e Grupos de Trabalhos-GT, com o objetivo de estudar e emitir parecer a respeito dos problemas identificados na Bacia. Em virtude da não continuidade das ações, se extinguiu automaticamente e os relatórios emitidos se encontram no Comitê. Durante este período as Câmaras Técnicas e GT emitiram parecer para ser discutido e deliberado nas plenárias do CBHS sobre entre outros, os seguintes temas: Aterro Sanitário, poluição dos rios afluentes (rio do Sal, rio Poxim e outros), mortandade de peixes, relatório de Impacto de Vizinhança da Ponte Aracaju /Barra dos Coqueiros. Cabe lembrar que as decisões tomadas podem ser transformadas em Resoluções e publicadas pelo Órgão Gestor.

Dando continuidade ao processo de gestão de recursos hídricos, o CONERH estabeleceu as diretrizes e critérios de funcionamento somente em 2012, considerando um período longo para definir a atualização dos Regimentos Internos dos Comitês das Bacias Hidrográficas, dos quais constam os atos administrativos e consultivos através das Deliberações, Resoluções e Moções publicados oficialmente pelo Órgão Gestor depois da aprovação dos membros.

Conclui-se, portanto, que faz-se necessário que os membros do Comitê da Bacia Hidrográfica do rio Sergipe acompanhem os aspectos legais e estruturantes na gestão das águas, devendo considerar a participação como algo importante para a sociedade, expressando os princípios de liberdade, impessoalidade, moralidade, publicidade e eficiência que devem nortear a atividade do representante.

\section{REFERÊNCIAS}

[1] BRASIL. Presidência da República. Decreto 24.643/1934. Decreta o Código de Águas.Rio de Janeiro/RJ, 1934. Disponível em: http://www.planalto.gov.br/ccivil_03/decreto/d24643.htm. Acesso em 10 de mar de 2013.

[2] BRASIL. Agência Nacional de Águas (ANA). Apoio à Gestão de Recursos Hídricos. 2013. Disponível em: http://www2.ana.gov.br/Paginas/institucional/SobreaAna/gestaoderecursoshid ricos.aspx. Acesso em 06 de maio de 2013

[3] BRASIL. MINISTÉRIO DO MEIO AMBIENTE. Lei 9.433 Institui a Política Nacional de Recursos Hídricos e cria o Sistema Nacional de Gerenciamento de Recursos Hídricos. Brasília /DF:Diário Oficial da União, 1997. Disponível em http://www.planalto.gov.br/ccivil_03/LEIS/19433.htm. Acesso em 10 de maio de 2013. 
[4] CLARKE, Robin T., 1934 - 0 Atlas da Água/Robin Clarke e Jannet King; [tradução Anna Maria Quirino], -São Paulo: Publifolha, 2005.

[5] MACHADO, Paulo Afonso Leme. Recursos Hídricos: direito brasileiro e internacional. São Paulo/SP, Malheiros Editores Ltda, 2002.

[6] MINISTÉRIO DO MEIO AMBIENTE. O desafio para o próximo milênio. Brasília/ DF: Diário Oficial da União, 2001.

[7] SERGIPE, Secretaria de Estado do Planejamento e da Ciência e Tecnologia - SEPLANTEC. Superintendência de Recursos Hídricos - SRH. Gestão participativa das águas de Sergipe. Aracaju, 2002. 88p.

[8] SERGIPE. Secretaria Estadual de Meio Ambiente e Recursos Hídricos - SEMARH. Regimento Interno do Comitê da Bacia Hidrográfica do Rio Sergipe. Sergipe, 2012.

[9] SERGIPE. Atlas Digital sobre Recursos Hídricos de Sergipe. Sistema de Informações sobre Recursos Hídricos de Sergipe - $\quad$ SIRHSE. Sergipe, $2012 . \quad$ Disponível em: http://www.semarh.se.gov.br/http://sirhse.semarh.se.gov.br/sirhse/index.php/ geoinformacao/index Acesso em 12 de abr de 2013.

[10] SERGIPE. Lei 3.870 de 25 de setembro de 1997 que institui a Política Estadual de Recursos Hídricos de Sergipe. Sergipe, 1997. Disponível em: http://www.semarh.se.gov.br/modules/tinyd0/index. php?id=26 Acesso em: 05 de mar de 2013.

[11] SERGIPE, CONERH/SE. Resolução no 15, de 28 de março de 2012. Estabelece diretriz e critérios para o funcionamento e a renovação de Comitês da Bacia Hidrográfica no âmbito do Estado de Sergipe e dá outras providências. Diário Oficial, Aracaju/SE, 19 jun. 2012. № 26.505. 


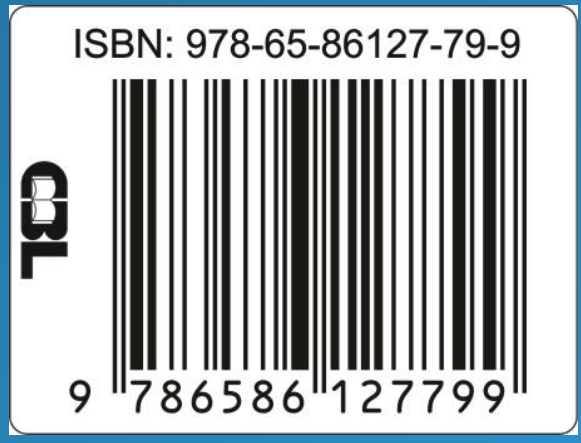

